\title{
Characterization of the 618-11 Solid Waste Burial Ground, Disposed Waste, and Description of the Waste-Generating Facilities
}

Prepared by

J. A. Demiter

W. O. Greenhalgh

SESC

Date Published

October 1997

Prepared for Waste Management Federal Services, Inc.

Project Hanford Management Contractor for the

U.S. Department of Energy under Contract DE-ACO6-96RL13200

Approved for public release; distribution is unlimited 


\section{RELEASE AUTHORIZATION}

Document Number: HNF-EP-0649, Revision 0

$\begin{array}{ll}\text { Characterization of the 618-11 Solid Waste Burial } \\ \text { Gocument Title: } & \begin{array}{l}\text { Ground, Disposed Wastes, and Description of the } \\ \text { Waste Generating Facilities }\end{array}\end{array}$

This document, reviewed in accordance with DOE Order 1430.1D, "Scientific and Technical Information Management," and DOE G 1430.1D-1, "Guide to the Management of Scientific and Technical Information," does not contain classified or sensitive unclassified information and is:

\section{APPROVED FOR PUBLIC RELEASE}

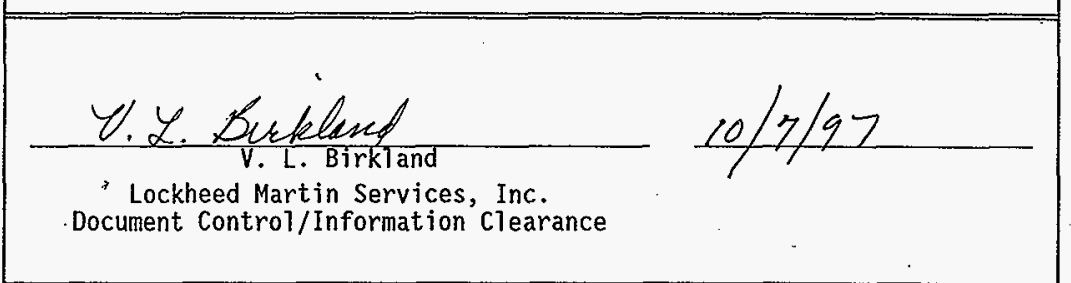

Reviewed for Applied lechnology, Business Sensitive, Classitied, Copyrighted, Export Controlled, Patent, PersonallPrivate, Proprietary, Protected CRADA, Trademark, Unclassified Controlled Nuclesr Information.

Trademark Disclaimer. Reference herein to any specific commercial product, process, or service by trade name, trademark, manufacturer, or othenwise, does not necessarily constitute or imply its endorsement, racommendation, or favoring by the United States Government or any agency thereof or its contractors or subcontractors. The views and opinions of authors exprassed herein do not nocessarily state or reflect those of the United States Government or any agency thereof. This report has been reproduced from the best available copy.

Printed in the United States of America.

Available to the U.S. Department of Energy and its contractors from the U.S. Department of Energy Office of Scientific and Technical Infomation, P.O. Box 62, Oak Ridge, TN 37831: Telephone: 423/576-8401.

Available to the public from the U.S. Department of Commerce National Technical Information Service, 5285 Port Royal Road, Springfield, VA 22161; Telephone: 703/487-4650. 


\title{
CHARACTERIZATION OF THE 618-11 SOLID WASTE BURIAL GROUND, DISPOSED WASTES, AND DESCRIPTION OF THE WASTE GENERATING FACILITIES
}

\author{
J. A. Demiter \\ W. O. Greenhalgh
}

\section{EXECUTIVE SUMMARY}

The 618-11 (Wye or 318-11) burial ground received transuranic (TRU) and mixed fission solid waste from March 9, 1962, through October 2, 1962. It was then closed for 11 months so additional burial facilities could be added. The burial ground was reopened on September 16,1963, and continued operating until it was closed permanently on December 31,1967 . The burial ground received wastes from all of the 300 Area radioactive material handling facilities.

The purpose of this document is to characterize the 618-11 solid waste burial ground by describing the site, burial practices, the disposed wastes, and the waste generating facilities. This document provides information showing that kilogram quantities of plutonium were disposed to the drum storage units and caissons, making them transuranic (TRU). Also, kilogram quantities of plutonium and other TRU wastes were disposed to the three trenches, which were previously thought to contain non-TRU wastes. The site burial facilities (trenches, caissons, and drum storage units) should be classified as TRU and the site plutonium inventory maintained at five kilograms. Other fissile wastes were also disposed to the site.

Additionally, thousands of curies of mixed fission products $\left(\mathrm{Sr}^{90}, \mathrm{Cs}^{137}, \mathrm{Pm}^{147}, \mathrm{Cm}^{244}\right.$, $\mathrm{Ru}^{103}, \mathrm{Ce}^{\mathrm{i44}}$, and others ) were also disposed to the trenches, caissons, and drum storage units. Most of the fission products have decayed over several half-lives, and are at more tolerable levels. Of greater concern, because of their release potential, are TRU radionuclides $\mathrm{Am}^{241}$, $\mathrm{Pu}^{238}, \mathrm{Pu}^{240}$, and $\mathrm{Np}^{237}$. TRU radionuclides also included slightly enriched 0.95 and $1.25 \% \mathrm{U}^{235}$ from N-Reactor fuel, which add to the fissile content.

The 618-11 burial ground is located approximately 100 meters due west of Washington Nuclear Plant - No. 2. The burial ground consists of three trenches, approximately 900 feet long, 25 feet deep, and 50 feet wide, running east-west. The trenches constitute $75 \%$ of the site area. There are 50 drum storage units (five 55-gallon steel drums welded together) buried in three rows in the northeast corner. In addition, five eight-foot diameter caissons are located at the west end of the center row of the drum storage units. Initially, wastes disposed to the caissons and drum storage units were from the 325 and 327 building hot cells. Later, a small amount of remotehandled (RH) waste from the 309 building Plutonium Recycle Test Reactor (PRTR) cells, and the newly built 324 building hot cells, was disposed at the site. 
The radionuclide beta/gamma activity of solid waste disposed at the burial ground was generally divided into three categories: $<10 \mathrm{nCi} / \mathrm{g}$ (low-activity), 10 to $1,000 \mathrm{nCi} / \mathrm{g}$ (moderateactivity), and above $1,000 \mathrm{nCi} / \mathrm{g}$ (high-activity). The low-activity wastes were primarily disposed in trenches, while the moderate and high-activity wastes were disposed in drum storage units and caissons. Exceptions to this general rule do exist. Much of the moderate and highactivity wastes were disposed to the trenches from 1962 to 1964 in concrete/lead-shielded drums. Also, some of the highly radioactive carton wastes had to be shielded or specially packed to minimize personnel exposure during transit, making it similar to waste later designated as $\mathrm{RH}$. The balance of low-activity waste exhibited little or no beta/gamma activity, or dose rate.

The discrepancy in the number of waste disposal facilities (caissons) does exist at the site. Recent geophysical investigations of the site indicated there are five anomalies, presumed caissons, but the grid of exploration was too large to confirm the exact size of the units. It is recommended that additional site investigations be conducted to confirm the sizes of the detected anomalies.

Wastes disposed at the burial ground also contained hazardous chemical components. These wastes will have to be handled as a mixed waste (MW) as the site is remediated. Several contamination spreads occurred at the burial ground over the course of its operation.

Stabilization techniques conducted in the 1980's have eliminated any detectable chemical or radiological contamination to the environment. Based upon subsurface monitoring- well measurements near the burial ground, no radiocontaminants or chemicals attributed to the 618-11 burial ground have been detected. The ground water monitoring surveiliance has been operating for two decades. The present environmental status of the burial site will not hinder future site remediation activities. 


\section{TABLE OF CONTENTS}

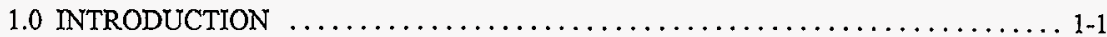

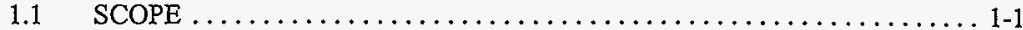

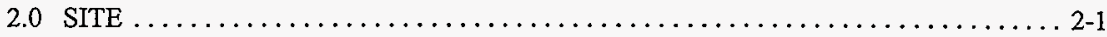

$2.1 \quad 618-11$ BURIAL GROUND SITE LOCATION $\ldots \ldots \ldots \ldots \ldots \ldots \ldots .2-1$

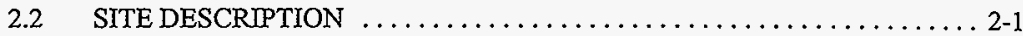

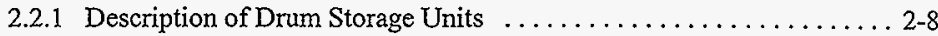

2.2.2 Description of Caissons $\ldots \ldots \ldots \ldots \ldots \ldots \ldots \ldots \ldots \ldots \ldots \ldots \ldots \ldots \ldots \ldots \ldots, 2-8$

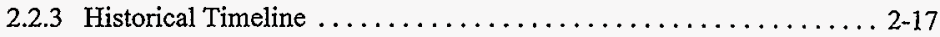

2.2.4 Site Description Based on Hanford Drawings $\ldots \ldots \ldots \ldots \ldots \ldots .2-17$

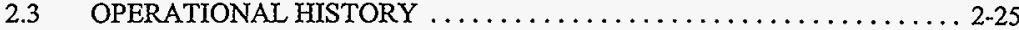

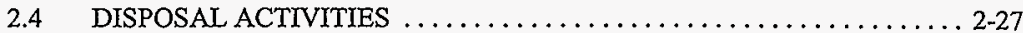

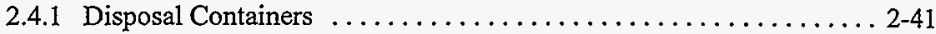

2.5 WASTE SITE DATA DISCREPANCIES $\ldots \ldots \ldots \ldots \ldots \ldots \ldots \ldots \ldots \ldots \ldots \ldots$

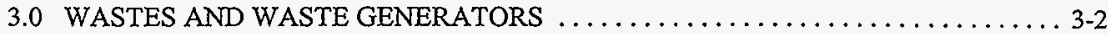

3.1 HISTORY OF 300 AREA. WASTE GENERATORS DISPOSING ...... 3-2 OF WASTE TO 618-11

3.1.1 History of the PRTR and Fuels Fabrication Facility ......... 3-11

3.1.2 History of the 325 Building from 1962 to $1968 \ldots \ldots \ldots \ldots \ldots$. $3-14$

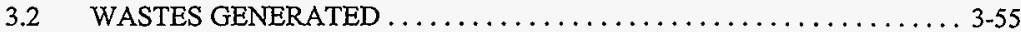

3.3 LOW-ACTIVITY CONTAMINATED WASTE $\ldots \ldots \ldots \ldots \ldots \ldots \ldots ., 62$

3.4 INTERMEDIATE-ACTIVITY CELL WASTE $\ldots \ldots \ldots \ldots \ldots \ldots \ldots \ldots .626$

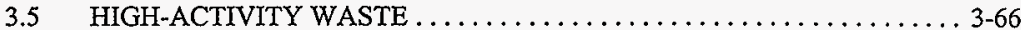

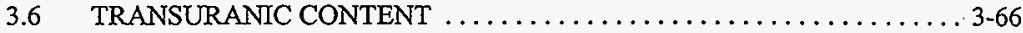

3.7 ' TRU CONTENT COMPARISONS $\ldots \ldots \ldots \ldots \ldots \ldots \ldots \ldots \ldots \ldots \ldots \ldots \ldots \ldots$

3.8 SOURCE MATERIAL AND BY-PRODUCT CONTENT $\ldots \ldots \ldots \ldots .3-72$

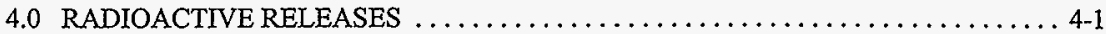

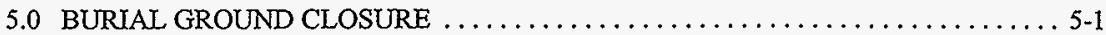

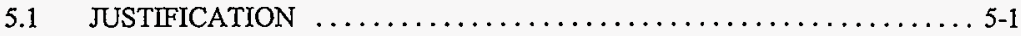

$5.2 \quad$ STABILIZATION $\ldots \ldots \ldots \ldots \ldots \ldots \ldots \ldots \ldots \ldots \ldots \ldots \ldots, 5-2$ 


\section{TABLE OF. CONTENTS continued}

6.0 MONITORING AND SURVEILLANCE $\ldots \ldots \ldots \ldots \ldots \ldots \ldots \ldots \ldots \ldots \ldots, 6,1$

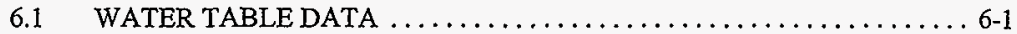

6.2 WELL MONITORING $\ldots \ldots \ldots \ldots \ldots \ldots \ldots \ldots \ldots \ldots \ldots \ldots \ldots, 1$

6.3 SITE MONITORING $\ldots \ldots \ldots \ldots \ldots \ldots \ldots \ldots \ldots \ldots \ldots \ldots \ldots, 6,8$

7.0 INTERVIEWS $\ldots \ldots \ldots \ldots \ldots \ldots \ldots \ldots \ldots \ldots \ldots \ldots \ldots \ldots \ldots \ldots \ldots \ldots \ldots \ldots \ldots \ldots \ldots, 1$

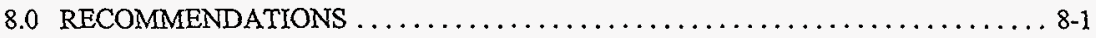

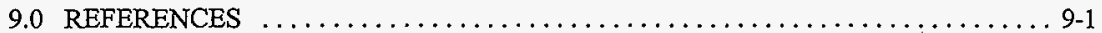

APPENDIX A

APPENDIX B

APPENDIX C

APPENDIX D

APPENDIX E

APPENDIX $F$

APPENDIX G

APPENDIX $H$

APPENDIX I 


\section{LIST OF TABLES}

Table 2-1: Data Sheet on the 618-11 Burial Ground $2-6$

Taken from PNL - 7008 (1991)

Table 2-2: $618-11$ Burial Ground Historical Timeline $\ldots \ldots \ldots \ldots \ldots \ldots \ldots \ldots \ldots .2-22$

Table 2-3: $618-11$ Burial Ground Drawing Revisions Examination $\ldots \ldots \ldots \ldots \ldots \ldots$ 2-23

Table 3-1: The Major PRTR Operational Activities Chart ................. 3-12

Table 3-2: 325-A Hot Cells - Work Activities ....................... 3-18

Table 3-3: 325A Hot Cells Disposal Record, 1961-1967 .................... 3-20

Table 3-4: Directory of 327 Building Cells (Autumn 1962) . ................ 3-45

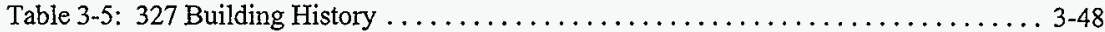

Table 3-6: The Representative Contents of Simulated 327 . . . . . . . . . . . . . . 3-49

Remote Handled Transuranic Waste

Table 3-7: $618-10$ and 618-11 Burial Ground Shipping Records . . . . . . . . . . . 3-57

Table 3-8: Solid Waste Disposal Summary 1962 to $1964 \ldots \ldots \ldots \ldots \ldots \ldots \ldots \ldots \ldots$ 3-58 from Monthly Activity Reports

Table 3-9a: Radiological Survey Records (PNL, 1965) … . . . . . . . . . . . . . 3-59

Table 3-9b: Radiological Survey Records (PNL, 1965) $\ldots \ldots \ldots \ldots \ldots \ldots \ldots \ldots \ldots$ 3-60

Table 3-9c: Radiological Survey Records (PNL, 1967) …............... 3-61

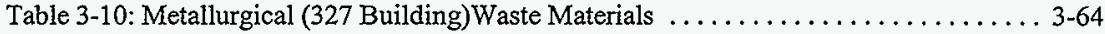

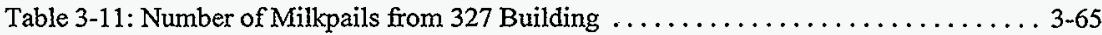

Table 3-12: 300 Area Waste Shipment volumes Generated..$\ldots \ldots \ldots \ldots \ldots \ldots \ldots$. 3-69

by Hanford Engineering Development Laboratory

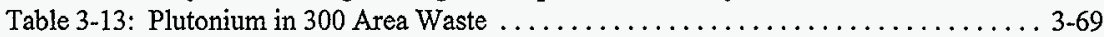

Table 3-14: The Average Hanford Site Soild Waste Fissile Density $\ldots \ldots \ldots \ldots \ldots \ldots .3-71$

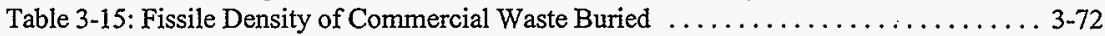
During 1966-67

Table 6-1: HEIS Monitoring Well Data $\ldots \ldots \ldots \ldots \ldots \ldots \ldots \ldots \ldots \ldots \ldots .6 .8$ 


\section{LIST OF FIGURES}

Figure 2-1: Hanford Site Map $\ldots \ldots \ldots \ldots \ldots \ldots \ldots \ldots \ldots \ldots \ldots \ldots \ldots \ldots \ldots \ldots \ldots \ldots \ldots \ldots \ldots \ldots, 2$

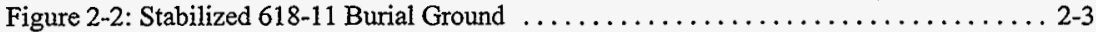

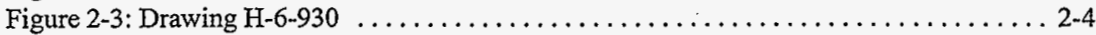

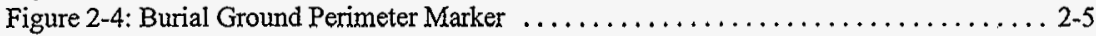

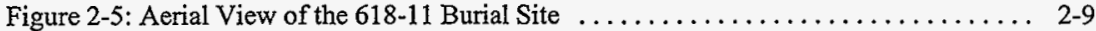

Figure 2-6: Aerial View of the 618-11 Burial Ground, First Enlargement ........... 2-10

Figure 2-7: Aerial View of the 618-11 Burial Ground, Second Enlargement .......... 2-11

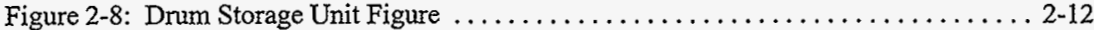

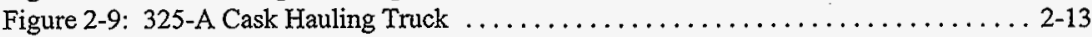

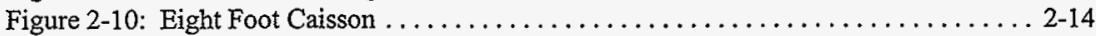

Figure 2-11: Possible Caisson Location Options at the 618-11 Burial ............ 2-15

Ground Along N12,428.24 Between W2,939.17 and W2,906.67 2-16

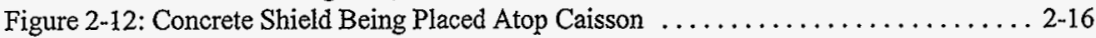

Figure 2-13: Caisson Off-set Dump Chutes .......................... 2-18

Figure 2-14: 618-11 Final Enlargement of Aerial View $\ldots \ldots \ldots \ldots \ldots \ldots \ldots \ldots \ldots .2 .19$

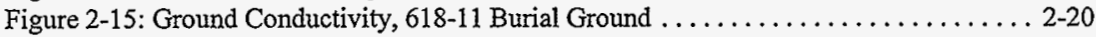

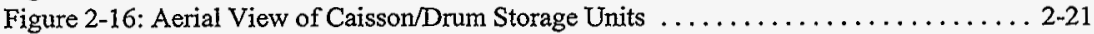

EMI Overlay Positions

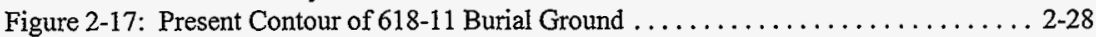

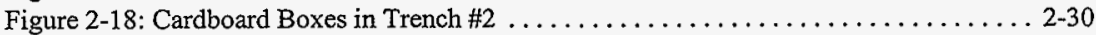

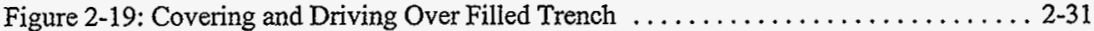

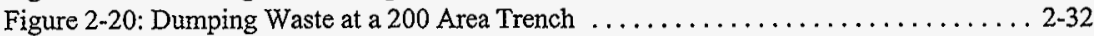

Figure 2-21: 325-A Cask-Hauling Truck in Dump Position $\ldots \ldots \ldots \ldots \ldots \ldots \ldots \ldots .2-35$

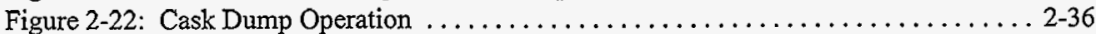

Figure 2-23: Waste Disposed to 200 Area Caisson $\ldots \ldots \ldots \ldots \ldots \ldots \ldots \ldots \ldots \ldots .2-37$

Figure 2-24: Condition of Waste Containers in Caissons (200 Area) ............ 2-38

Figure 2-25: Condition of Waste Containers in Caissons (200 Area) $\ldots \ldots \ldots \ldots \ldots .22-39$

Figure 2-26: Condition of Waste Containers in Caissons (200 Area) $\ldots \ldots \ldots \ldots \ldots \ldots .40$

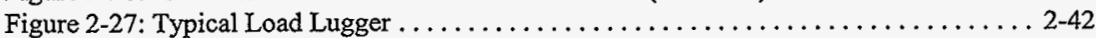

Figure 2-28: 325-A Hot Cells High Activity Waste Disposal $\ldots \ldots \ldots \ldots \ldots \ldots \ldots .2-44$

Method 1960-1964

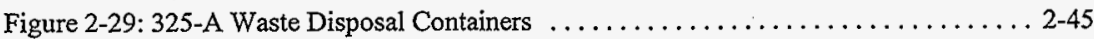

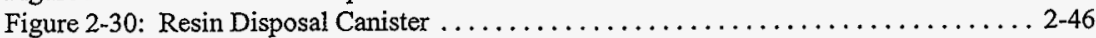

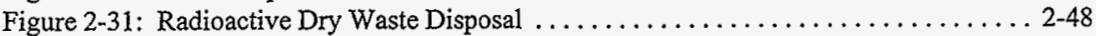

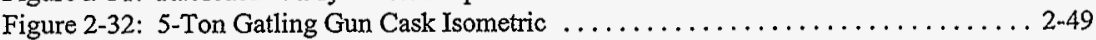

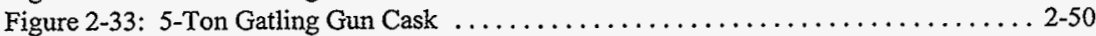

Figure 2-34: 3/4-Ton Milk Pail Cask .............................. 2-51

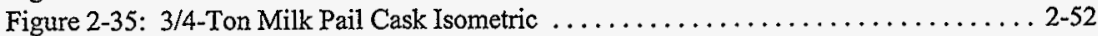

Figure 2-36: Tilt-Bed Truck for Cask Waste Disposal $\ldots \ldots \ldots \ldots \ldots \ldots \ldots \ldots \ldots .2-55$

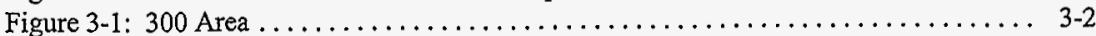

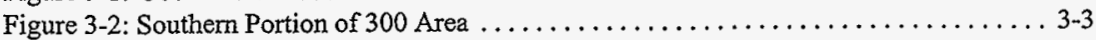

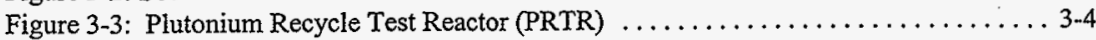

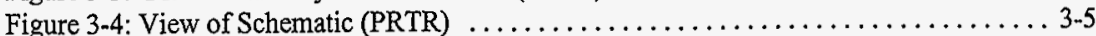

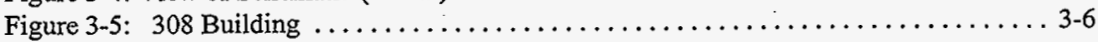




\section{LIST OF FIGURES continued}

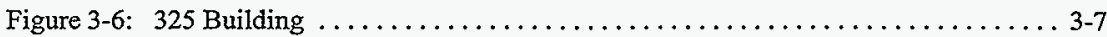

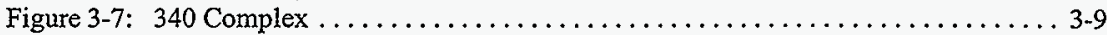

Figure 3-8: Schematic View of Plutonium Fuels Pilot Plant $\ldots \ldots \ldots \ldots \ldots \ldots \ldots \ldots, 13$

Figure 3-9: 325 Radiochemistry Building $\ldots \ldots \ldots \ldots \ldots \ldots \ldots \ldots \ldots \ldots \ldots \ldots \ldots \ldots \ldots \ldots \ldots \ldots, 15$

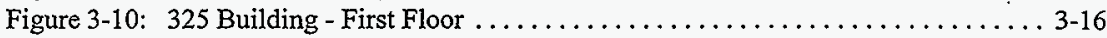

Figure 3-11: Salt Cycle Process ................................ 3-24

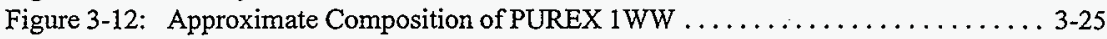

Figure 3-13: PUREX Plant Strontium Discovery Flowsheet $\ldots \ldots \ldots \ldots \ldots \ldots \ldots \ldots .26$

Figure 3-14: "A" Cell Spray Calciner Mock-up . . . . . . . . . . . . . . . . . . . . . 3-27

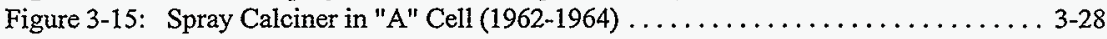

Figure 3-16: Spray Calciner in "A" Cell .......................... 3-29

Figure 3-17: $325-\mathrm{A} \mathrm{A}^{\prime} \mathrm{Cell} \mathrm{Pm}^{147}$ Ion Exchange (1960-1962) ............... 3-30

Figure 3-18: "A" Cell Spray Calciner Removal ....................... 3-31

Figure 3-19: "A" Cell" Pm ${ }^{147}$ Ion Exchange Pilot Plant (1960-1962) . . . . . . . . . . . . 3-32

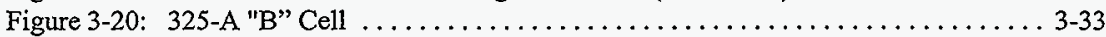

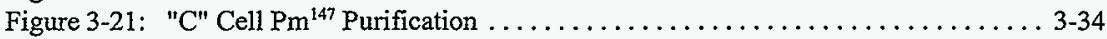

Figure 3-22: 325-A "C" Cell Salt Cycle Process $(1960-1962) \quad \ldots \ldots \ldots \ldots \ldots \ldots \ldots .3-35$

Figure 3-23: " $\mathrm{C}$ " Cell Salt Cycle Process Graphite Electrode ................. 3-36

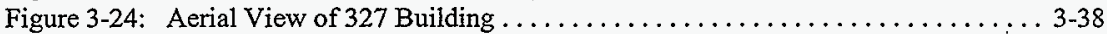

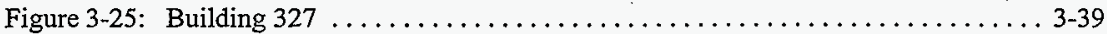

Figure 3-26: 327 Radiometallurgy Building Floor Plan $\ldots \ldots \ldots \ldots \ldots \ldots \ldots \ldots \ldots \ldots \ldots \ldots \ldots$

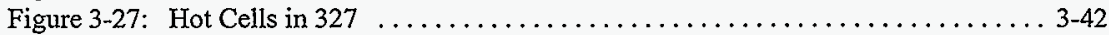

Figure 3-28: 327 Hot Cell Load Out $\ldots \ldots \ldots \ldots \ldots \ldots \ldots \ldots \ldots \ldots \ldots \ldots \ldots \ldots \ldots \ldots \ldots \ldots \ldots \ldots, 43$

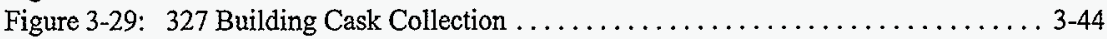

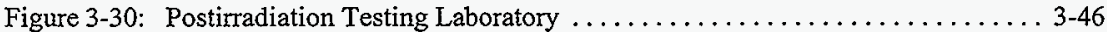

Figure 3-31: Typical Isometric View of 327 Hot Cell $\ldots \ldots \ldots \ldots \ldots \ldots \ldots \ldots \ldots \ldots .43 .47$

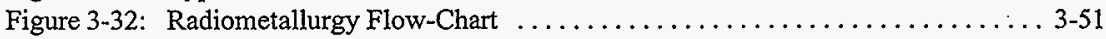

Figure 3-33: Radiometallurgy Gatling Gun Cask $\ldots \ldots \ldots \ldots \ldots \ldots \ldots \ldots \ldots \ldots . \ldots \ldots \ldots \ldots$

Figure 3-34: Radiometallurgy Milk Pail Cask ...................... 3-54

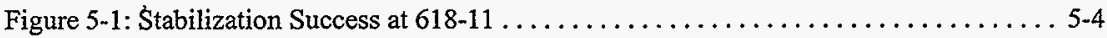

Figure 6-1: Hanford Site Map Well Locations $\ldots \ldots \ldots \ldots \ldots \ldots \ldots \ldots \ldots \ldots, 6$ 6.

Figure 6-2: $618-11$ Burial Site Tritium Concentration $\ldots \ldots \ldots \ldots \ldots \ldots \ldots \ldots \ldots, 6$ 6-3

Figure 6-3: $618-11$ Burial Site Nitrate Concentration $\ldots \ldots \ldots \ldots \ldots \ldots \ldots \ldots, 6,4$

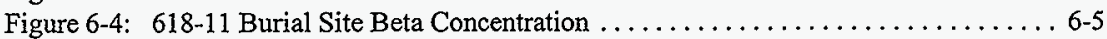

Figure 6-5: $618-11$ Burial Site Alpha Concentration ......................6.6.6

Figure 6-6: 618-11 USRADS Survey Radiological Profile Dose Rate . . . . . . . . . . . . . . 6-9

Figure 6-7: 618-11 USRADS Survey Radiological Profile Count Rate $\ldots \ldots \ldots \ldots \ldots .6$ 6-10 


\section{ACKNOWLEDGEMENT}

The authors would like to thank Robert B. Hall (retired) for his invaluable assistance in preparing this document. Bob had the insight to preserve valuable record and file data, which has been incorporated into this document. His knowledge of the Hanford Site history, and the Site philosophy of operations during the 1960 s was also greatly appreciated. 


\section{ABBREVIATIONS}

$\begin{array}{ll}\text { AEC } & \text { Atomic Energy Commission } \\ \text { BNWL } & \text { Battelle Northwest Laboratory } \\ \text { CRBR } & \text { Clinch River Breeder Reactor } \\ \text { CWS } & \text { control waste system } \\ \text { DOT } & \text { U.S. Department of Transportation } \\ \text { EDE } & \text { effective dose equivalent } \\ \text { EMI } & \text { elecromagnetic induction } \\ \text { FFTF } & \text { Fast Flux Test Facility } \\ \text { GPR } & \text { ground-penetrating radar } \\ \text { HEDL } & \text { Hanford Engineering and Development Laboratory } \\ \text { HEIS } & \text { Hanford Environmental Information System } \\ \text { HEPA } & \text { high-efficiency particulate air } \\ \text { MFP } & \text { mixed fission products } \\ \text { MW } & \text { mega watt } \\ \text { NDT } & \text { non-destructive testing } \\ \text { NDE } & \text { non-destructive examination } \\ \text { O.D. } & \text { outside diameter } \\ \text { PFL } & \text { Plutonium Fuel Laboratory } \\ \text { PIT } & \text { postirradiation Testing } \\ \text { PNL } & \text { Pacific Northwest Laboratory } \\ \text { PRTR } & \text { Plutonium Recycle Test Reactor } \\ \text { PUREX } & \text { Plutonium/Uranium Extraction (facility) } \\ \text { PWR } & \text { pressurized water reactor } \\ \text { REDOX } & \text { Reduction Oxidation Plant } \\ \text { RH } & \text { remote handling } \\ \text { R\&D } & \text { Research and Development } \\ \text { RLWS } & \text { Radioactive Liquid Waste System } \\ \text { ROD } & \text { Record of Decision } \\ \text { SNM } & \text { special nuclear material } \\ \text { SWTTS } & \text { Solid Waste Information Tracking System } \\ \text { USRADS } & \text { Ultrasonic Ranging and Data System } \\ \text { TRU } & \text { transuranic } \\ \text { WHC } & \text { Westinghouse Hanford Company } \\ \text { WIPP } & \text { Waste Isolation Pilot Plant } \\ \text { WNP-2 } & \text { Washington Nuclear Plant - No. 2 } \\ & \end{array}$




\section{CHARACTERIZATION OF THE 618-11 \\ SOLID WASTE BURIAL GROUND, DISPOSED WASTES, AND DESCRIPTION OF THE WASTE GENERATING FACILITIES}

\subsection{INTRODUCTION}

This document characterizes the 618-11 solid waste burial ground, the waste disposed at the site, and describes the facilities and activities that generated the wastes. Waste and site characterization data, including photographs, drawings, records research, and interviews were used to evaluate the site (to the extent possible). New data is presented, which was discovered during research for this document. These additional documents, files, photographs, and recently conducted site geophysical investigations provide the most complete, and up-to-date characterization of the $618-11$ burial ground.

The 618-11 burial ground is the only pre-1970, buried, suspect transuranic (TRU) contaminated, solid waste not located on the 200 Area plateau to be remediated (DOE 1987). The associated Record of Decision (ROD) implementation plan calls for removal of the solid TRU waste from the 618-11 site (McGuire 1988).

\subsection{SCOPE}

This document presents records, documents, and photographs of site, facility, and waste characterization data. This was done to develop a description of the buried materials; physical, chemical, and radiological characterization; location; classification; and an accurate layout of the 618-11 solid waste burial ground features.

The information contained in this report will be used as a key element in planning for remediation of the $618-11$ burial ground. 


\subsection{SITE}

\section{$2.1 \quad 618-11$ BURIAL GROUND SITE LOCATION}

The 618-11 burial ground site, known originally as the 300 Wye or later as the 318-11 burial ground, is located approximately 11 miles northwest of Richland, Washington, directly west of WNP-2. The site is in Section 5, T11N, R28E Willamette Meridian (Voiland 1970). The Hanford grid coordinates for the 618-11 site are:

East - W 2561 (Elevation at Northeast Corner 443 feet, Southeast Corner 448 feet) South - N 12103

West - W 3561 (Elevation at Northwest Corner 445 feet, Southwest Corner 450 feet) North - N 12478

Figure 2-1 shows the location of the 618-11 burial ground on the Hanford Site Map. A 1987 aerial photograph, Figure 2-2, gives a more graphic picture of the stabilized 618-11 site. (The boundary of the burial ground is shown by the dashed line.) The burial ground plot plan is shown in Figure 2-3, a reduced figure of drawing H-6-930 found in Appendix B.

\subsection{SITE DESCRIPTION}

The 618-11 burial ground site is a $375 \times 1000$ foot rectangle oriented east-west. The site is flat and has a total area of 8.6 acres. The burial ground perimeter is marked with identification markers 2-68-1 through 2-68-28. Marker 2-68-1 is located at the northeast corner (Figure 2-4).

The 618-11 site elevation is approximately 450 feet above mean sea level, with the water table approximately 60 feet below that (Brown 1977). A data sheet on the 618-11 site is given in Table 2-1 (PNNL 1991).

The burial ground consists of three backfilled trenches, 50 underground drum storage units, and five eight-foot diameter bottomless metal caissons. (Data supports two options for the number of caissons at the site, which will be discussed later and in detail in Section 2.5). The trenches are 900 feet long by 50 feet wide (surface dimensions) occupying all of the site except a 100 by 1000 foot section on the north side. The trenches are spaced 50 feet apart (edge to edge) and maintained 50 feet from the perimeter fence, except at the south side, where the trench edge is 25 feet from the fence (Figure 2-3).

The 618-11 burial ground was opened on March 9, 1962 and accepted wastes to Trench \#1( the first trench constructed) until October 3, 1962 (Backman 1963a). The burial ground was then taken out of service pending an Atomic Energy Commission (AEC) review and approval of the 618-11 burial ground location. During the closure period, a second trench and 40 vertical drum storage units were added (Berreth 1963, GE 1962-1964, Backman 1963a, and Appendix B). 
Figure 2-1: Hanford Site Map

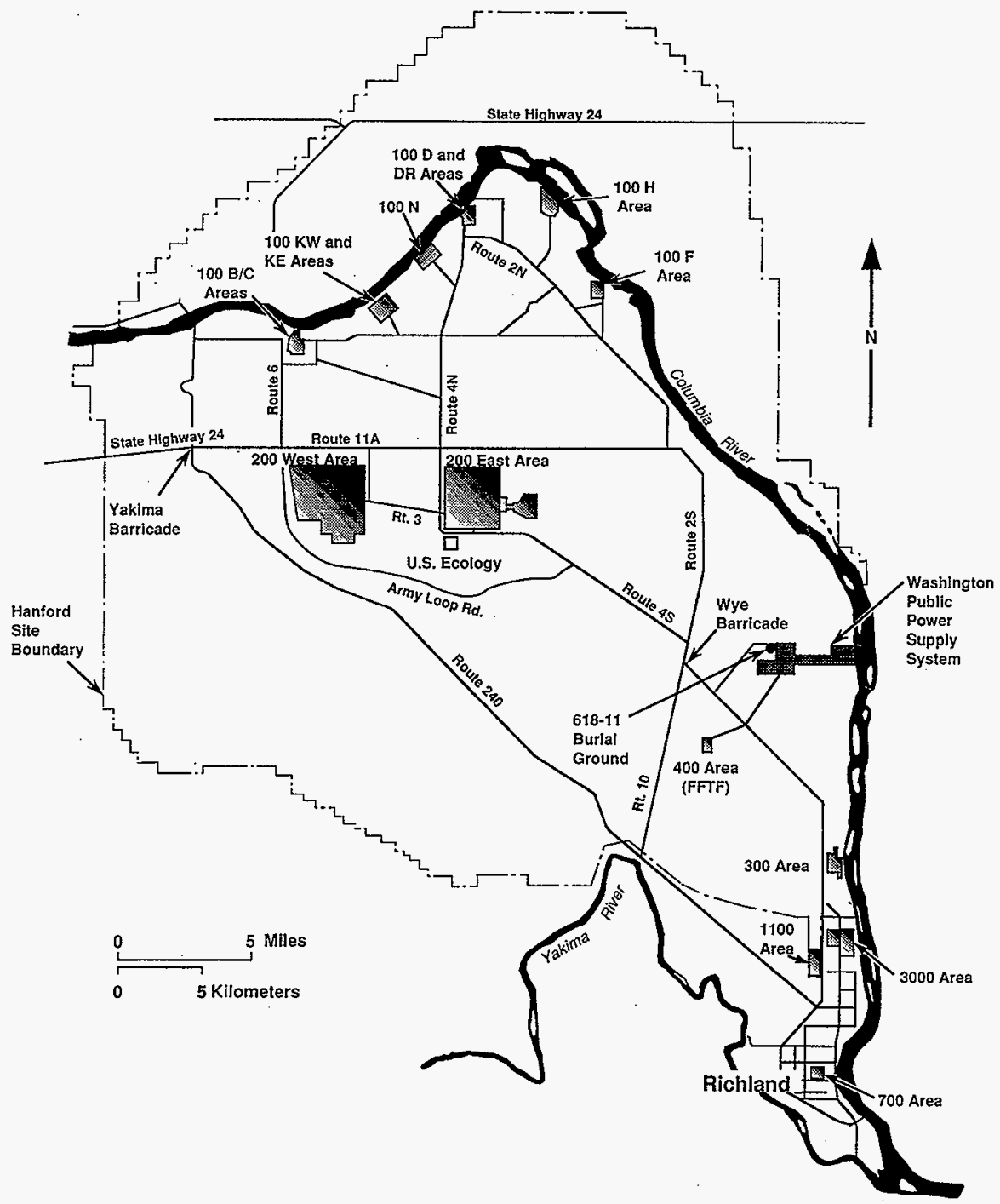




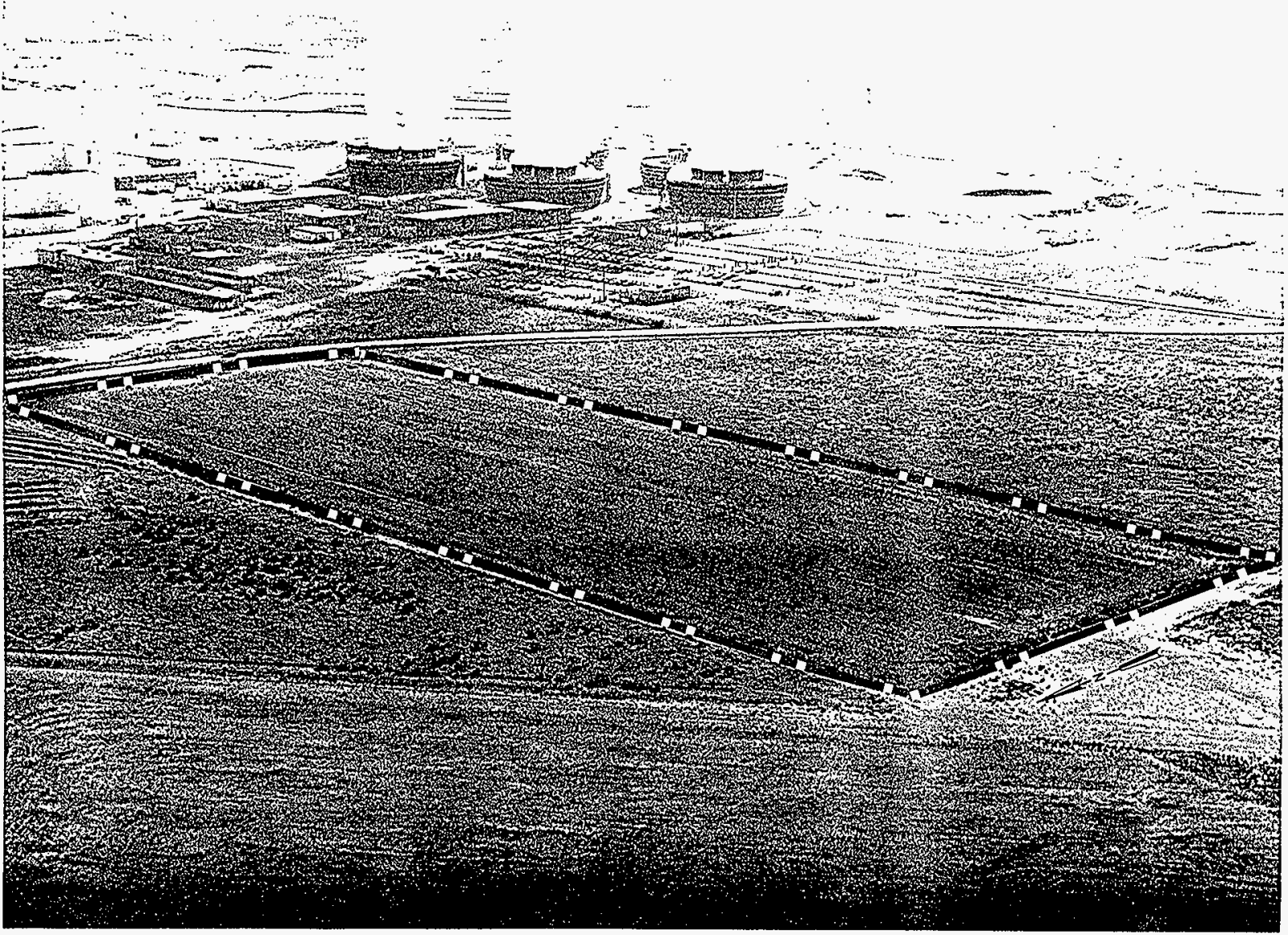


Figure 2-3: Drawing H-6-930

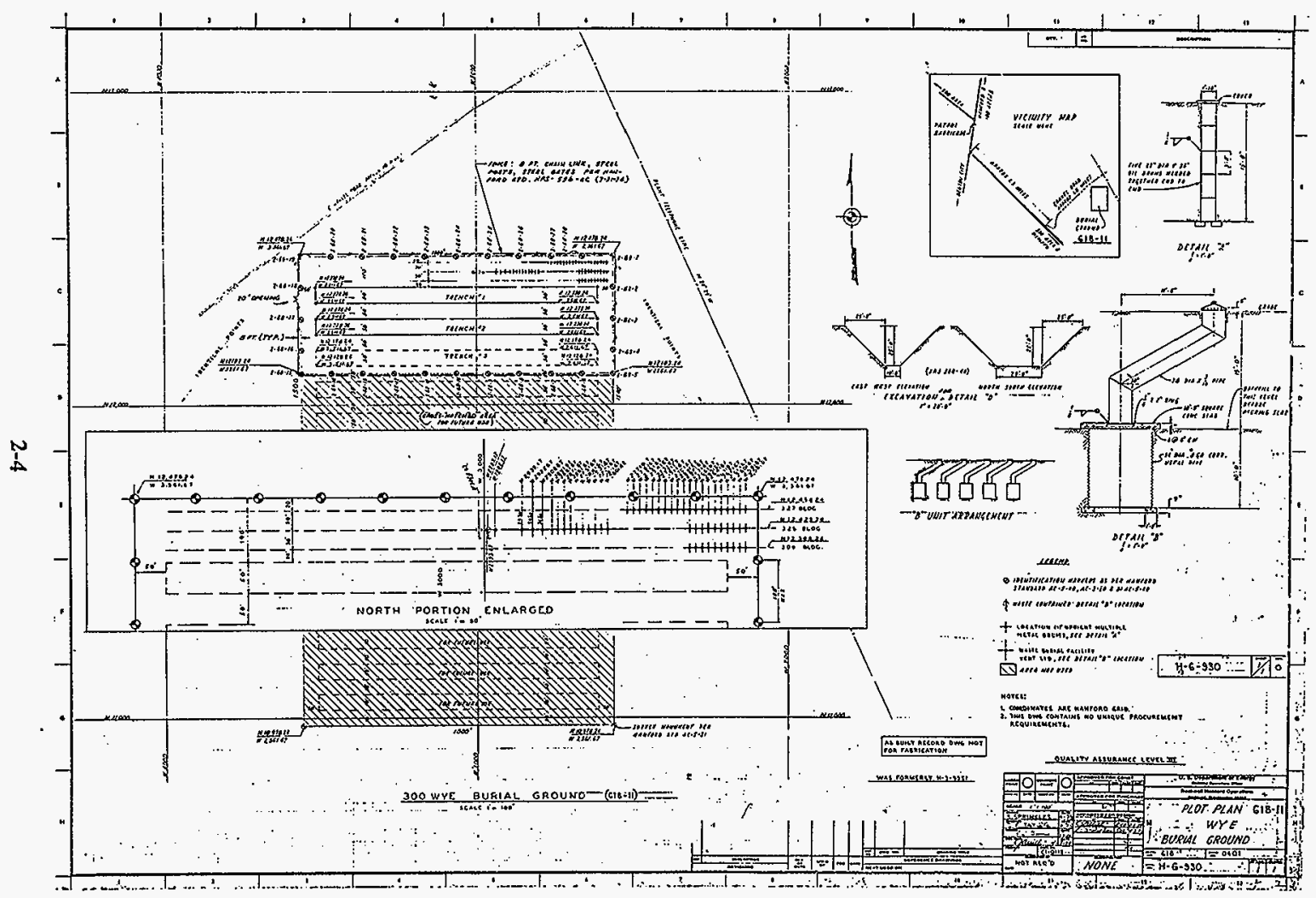




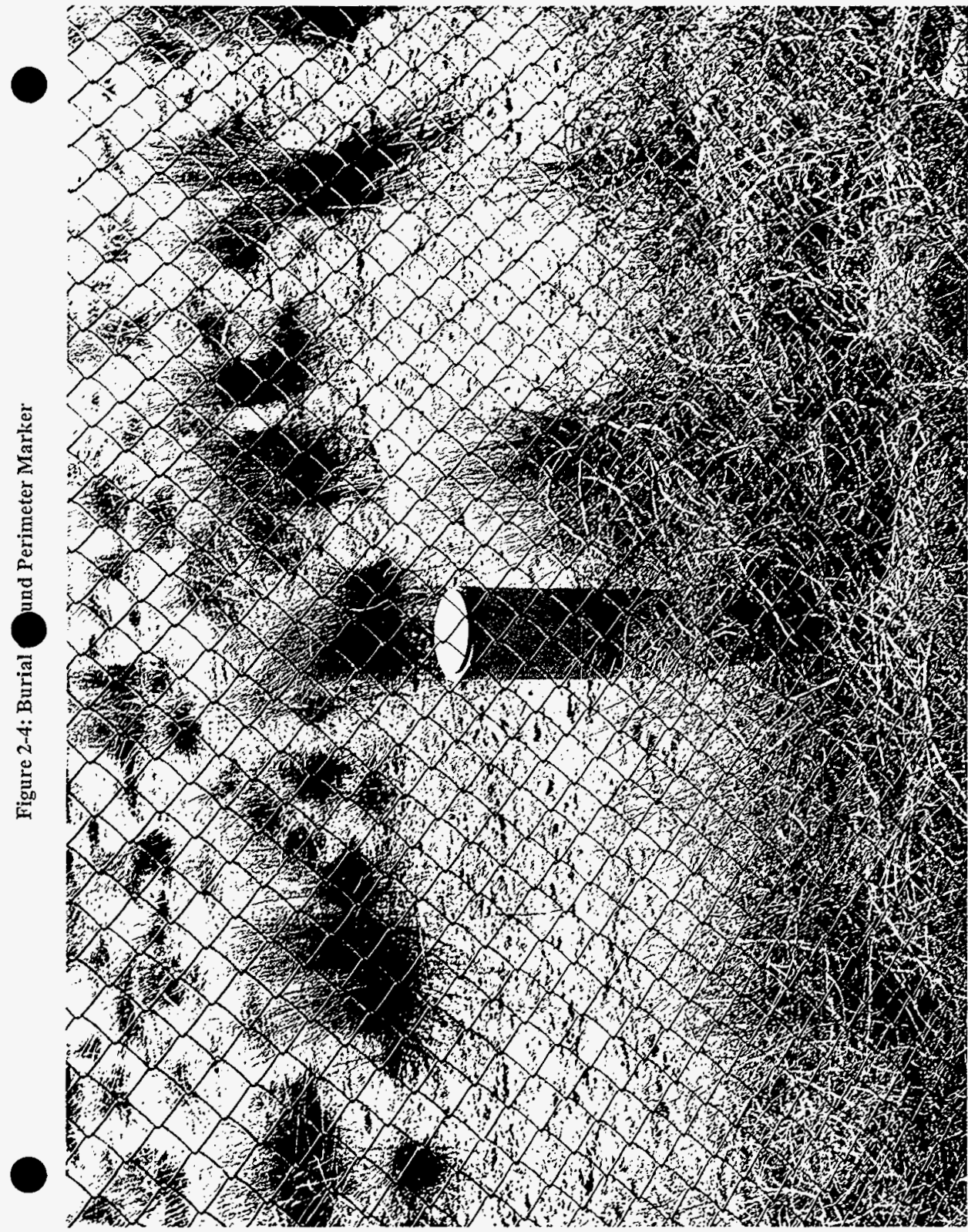


Table 2-1: Data Sheet on the 618-11 Burial Ground Taken from PNL - 7008 (1991)

\begin{tabular}{|c|c|c|}
\hline$\frac{\text { Name/Type of Facility }}{\text { Burial Ground }}$ & $\begin{array}{l}\text { Past Designation } \\
300 \text { WYE Burial Ground } \\
\text { "Y" Burial Ground }\end{array}$ & $\frac{\text { Number }}{318-11}$ \\
\hline $\begin{array}{l}\text { Location } \\
\text { About } 1-1 / 2 \text { miles northeast of the } \\
\text { Richland-Hanford Highway (Route } \\
4 \text { South), from a point } 7-1 / 3 \text { miles } \\
\text { northwest of the } 300 \text { Area. } \\
\text { (Figure C.1.1) }\end{array}$ & $\frac{\text { Service Dates }}{3 / 62-12 / 67}$ & $\frac{\text { Status }}{\text { Retired }}$ \\
\hline $\begin{array}{c}\text { Site Coordinates } \\
\text { Hanford Grid: W-2561, N-12103, } \\
\text { W-3561, N-12478 }\end{array}$ & $\begin{array}{l}\text { Reference Drawings } \\
\mathrm{H}-3-9951 \\
\mathrm{M}-6000\end{array}$ & \begin{tabular}{ll}
\multicolumn{2}{c}{ Elevations } \\
Ground & $\sim 430 \mathrm{ft}$. \\
Water Table & $\begin{array}{l}\sim 70 \mathrm{ft} . \\
(1973)\end{array}$ \\
Site Depth & $15 \mathrm{ft}$.
\end{tabular} \\
\hline \multicolumn{3}{|c|}{$\begin{array}{l}\text { Source and Description of Waste } \\
\text { The site is a repository for a broad spectrum of low-to-high-level dry radioactive wastes, } \\
\text { primarily fission products, and plutonium. Cartoned low-level wastes were buried in the } \\
\text { trenches and medium-to-high-level beta-gamma wastes in the pipe facilities and caissons. } \\
\text { Quantities probably amount to thousands of curies of beta-gamma wastes and } 10 \text { 's to } 100 \text { 's of } \\
\text { grams of plutonium. }\end{array}$} \\
\hline \multicolumn{3}{|c|}{$\begin{array}{l}\text { The site consists of a } 375 \times 1000 \text {-ft. rectangle oriented east-west. Total area is } 8.6 \text { acres. } \\
\text { Burial facilities include three backfilled trenches, } 900 \times 50 \text {-ft., occupying all of the site, except } \\
\text { a } 100 \times 1000 \text {-ft. strip on the north side. In the eastern half of this northern portion are located } \\
50 \text { vertical pipe storage units made by welding five each } 55 \text {-gal. drum sections together. Just } \\
\text { west of the pipe installations are four caisson storage facilities, consisting of } 8 \text {-ft. diameter by } \\
10 \text {-ft. high } 8 \text {-gauge corrugated metal pipe, buried } 15-\mathrm{ft} \text {. Below grade, and connected to the } \\
\text { surface by offset } 36 \text {-in. pipe. All pipe and caisson disposal facilities have been backfilled, } \\
\text { capped off with concrete, and covered with dirt. }\end{array}$} \\
\hline \multicolumn{3}{|c|}{ The burial ground perimeter is marked with Identification Markers 2-68-1 through 2-68-28. } \\
\hline $\begin{array}{l}\text { Radionuclide Content } \\
\text { Total Beta, Gamma } \\
\mathrm{Pu} \quad<100 \mathrm{~g}\end{array}$ & & \\
\hline
\end{tabular}


The AEC had also requested closure of the 618-10 burial ground. Construction of the second trench, along with installation of the 40 drum storage units, and several contamination spreads at 618-10 (300 North) burial ground, prompted reopening of the 618-11 burial ground on September 16, 1963. It was operated continuously until its permanent closure on December 31 , 1967 (Cadwell 1971). The closure period of October 1962 to September 1963 is supported by:

(1) General Electric Reference (1962), detailing

- 618-11 closure

- The AEC review process

- Construction of Trench \#2 at the site

- Construction of 30 or more drum storage units

- Continued operation at the 618-10 burial ground

(2) Appendix B, drawing $\mathrm{H}-3-9951$, Revision 4

- Showing the 40 drum storage units installed, dated $9 / 25 / 63$

(3) Appendix E, summation of 618-11 and 618-10 burial ground shipments January 1962 to December 1967

(4) Appendix F, summation of General Electric, 1962-1964 entries

(5) Appendix $\mathrm{H}$, Battelle Northwest Laboratory (BNW) contamination incidents at Hanford 1956-1971 (See Section 4.0 for further details).

Over the life time of the burial ground, three trenches were constructed. At closure of the burial ground in December 1967, Trench \#3 had not been completely used (Voiland 1970). The EMI/GPR data presented in Section 6.3 (Bergstrom 1997) supports this conclusion. Figure 2-3 indicates the trenches were 25 feet deep. The angle of repose is 1.0 vertical to 1.0 horizontal, or 45 degrees. Photographs indicate there was not a 10 feet. flat bottom as shown in Figure 2-3. 
Figures 2-5 and 2-6 show aerial photographs of the 618-11 burial ground taken August 19, 1964. Only the three caissons located on N12,428.24 between W2,939.17 and W2,906.67 had been installed at the $618-11$ burial ground by this date. This is supported by the several entries (GE 1962-1964) from June through September 1964. Clearly, the two caissons located along N12,428.24 between W3,008.67 and W2,982.17 had not been installed at the burial ground at this time (Figure 2-7). Figure 2-5 is taken looking due west while Figure 2-6 is taken at a west-southwest orientation. The trench being filled from the west is Trench $\# 2$, based on measurements given in Figure 2-3, H-3-9951 drawing as-built information, and the date given on drawing H-3-9951, Revision 4, which shows Trench \#3 was not added until 1965.

\subsubsection{Description of Drum Storage Units}

The vertical underground drum storage units were made by welding five 55-gallon steel drum sections together. The drum storage units are 22 inches in diameter, 15 feet long, with open tops and bottoms (Figure 2-8). The drum storage units are located in three rows at the northeast section of the burial ground (Figure 2-3).

Drum storage units were emplaced by trenching the area 15 feet. deep, then placing the units in the trench and backfilling (Phillips 1980). The drum storage units were emplaced on an as-needed basis. The first group of 40 was placed along N12,456.24, the eastern portion of N12,428.24, and N12,398.24 (Berreth 1963 and Appendix B, H-3-9951, Revision 3). A later group of 10 drum storage units was added on N12,428.24 between W2,801.67 and W2,891.67 between October 1963 and August 1964. It is probable that these last 10 units were installed between June 1964 and August 1964 with the three caissons located between W2,906.67 and W2,939.17 (GE, 1962-1964). The March 6, 1964 contamination event reported in Appendices H and $I$, and supported by Figure 2-9 and Appendix A data, suggest the drum storage units were filled, starting at the east. Spacing on the drum units is shown as 10 feet in Figure 2-3, which seems accurate based on aerial and ground photographs, and Electromagnetic induction (EMI) and Ground-penetrating radar (GPR) (Bergstrom 1997).

\subsubsection{Description of Caissons}

The caisson area is located just west of the center row of the drum storage units along $N 12,428.24$. The caisson design selected appears to be eight-foot in diameter by 10 feet high, 8 -gauge corrugated culvert-style metal pipe. The caissons are buried 15 feet below grade and are connected to the surface through an offset pipe (Figure 2-10). The eight-foot diameter caissons were spaced between 15 and 16.5 feet apart (Figure 2-11 and Figure 2-3). The centerline of the off-set dump chute was spaced 11.5 feet from the center of the caisson (Figure 2-3). A concrete slab was placed atop the caisson during construction to provide additional shielding. Figure 2-12 shows a similar concrete shield being placed atop a caisson during placement at the 200 West Area in 1978. After the placement of the concrete shield and 


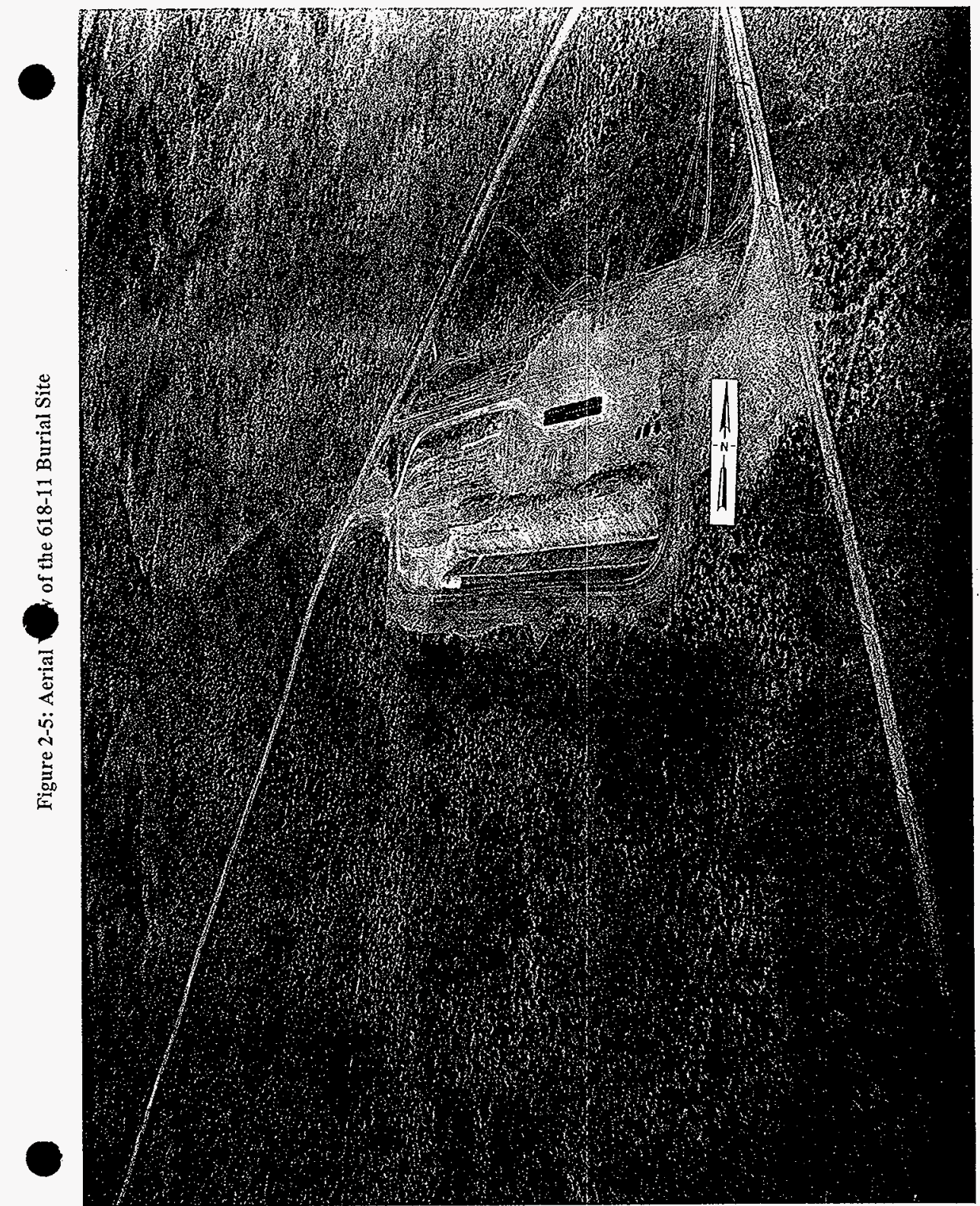


Q3y Figure 2-6: Aerial View of the 618-11 Burial Ground, First Enlargement

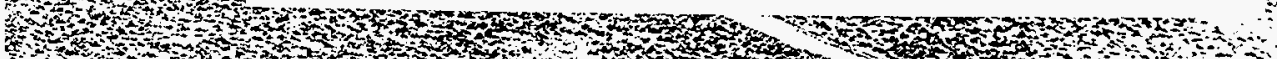

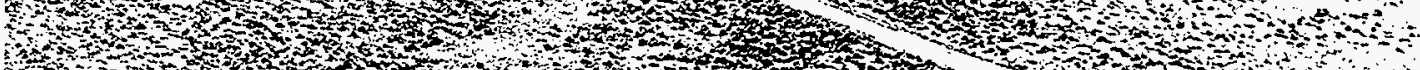

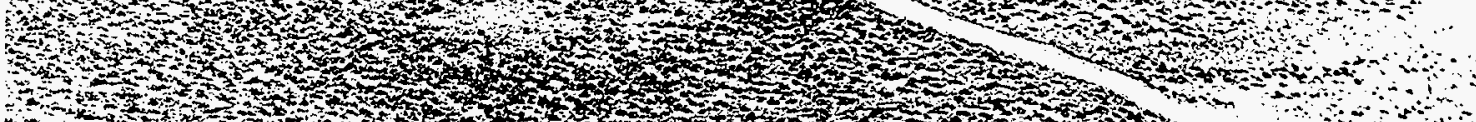

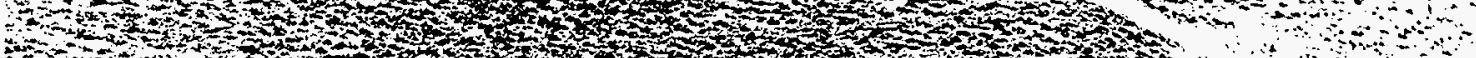
and

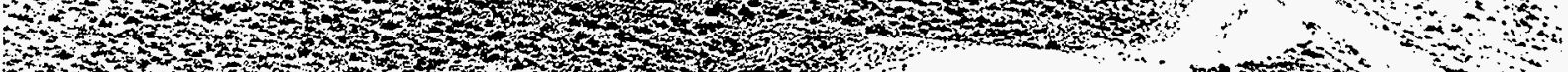

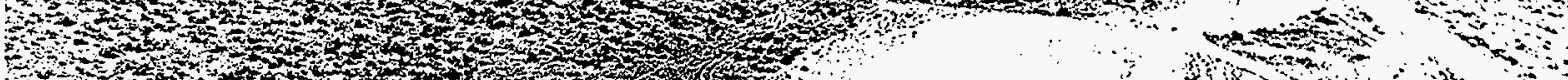

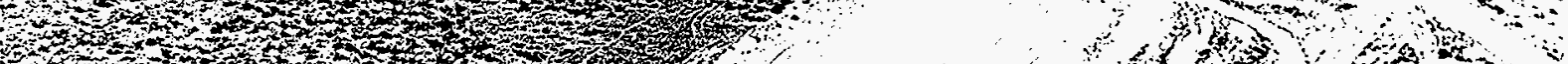
3
3

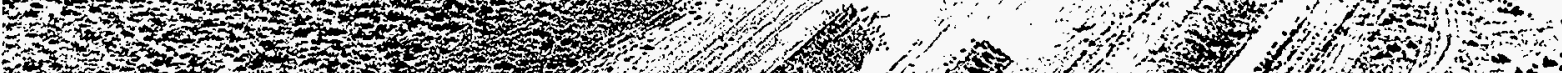

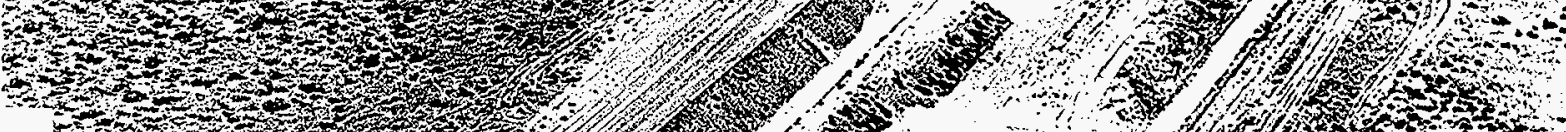

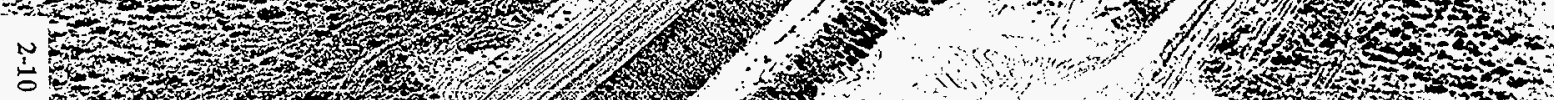

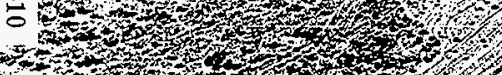

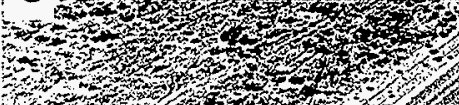
.0.

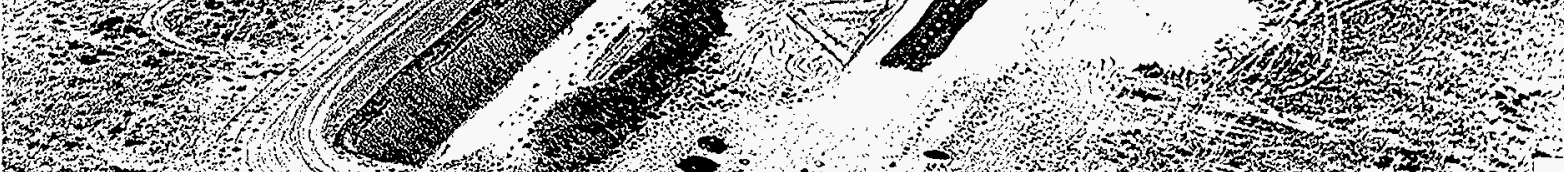

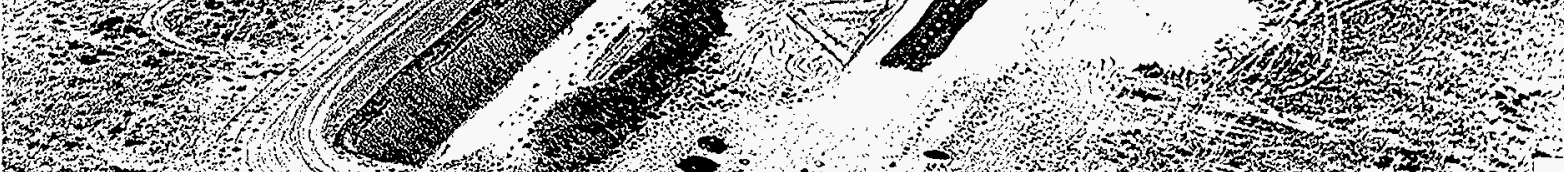

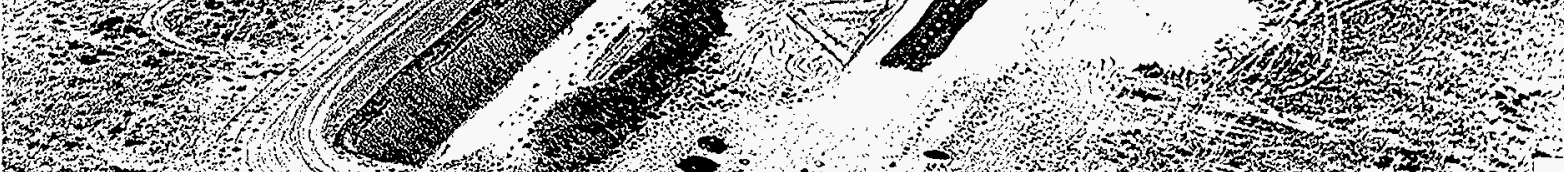

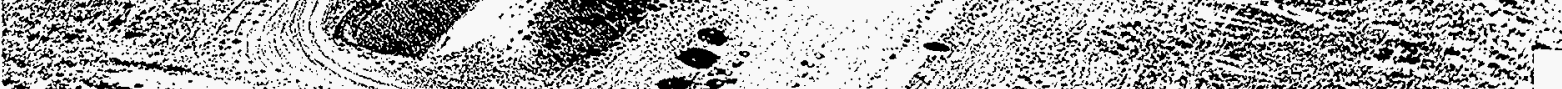

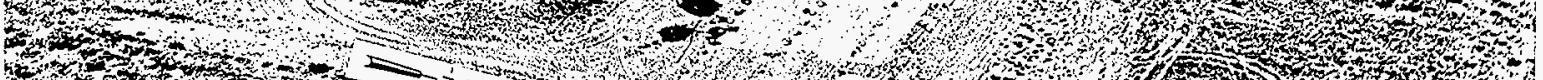

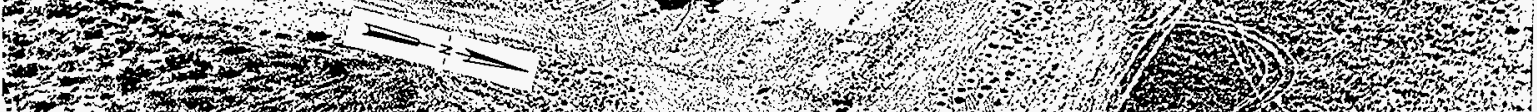

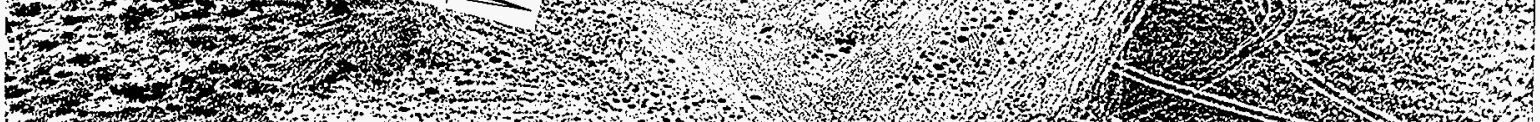

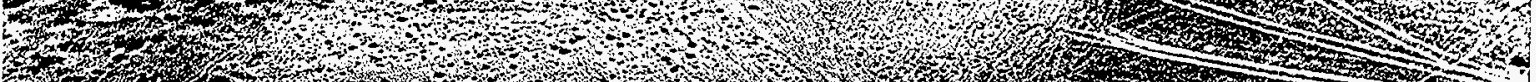

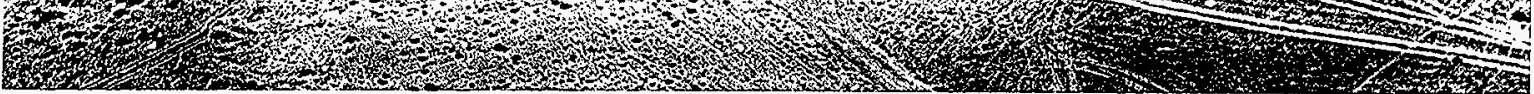




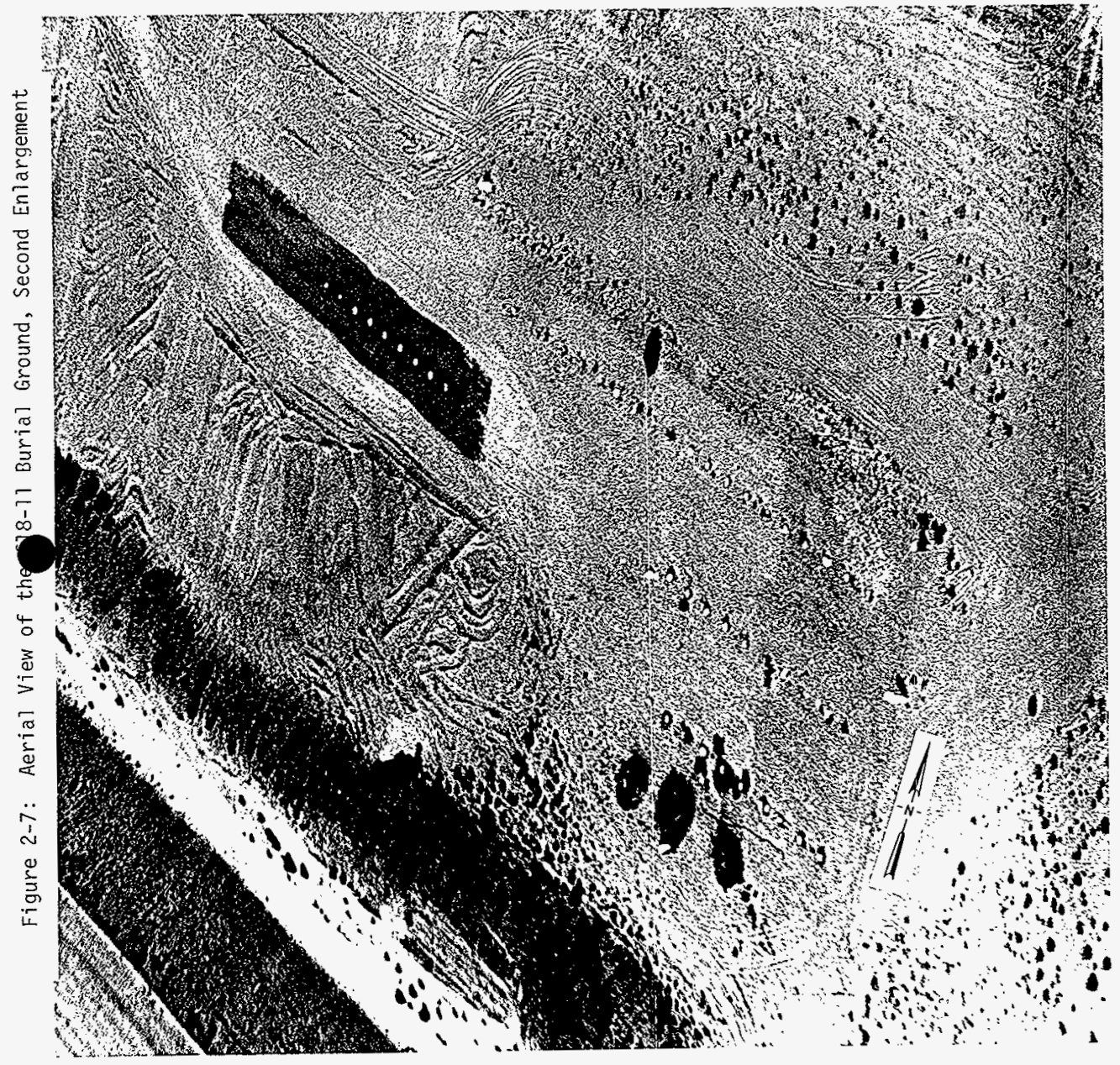




\section{Fieure 2s: Drum Storage Unit}

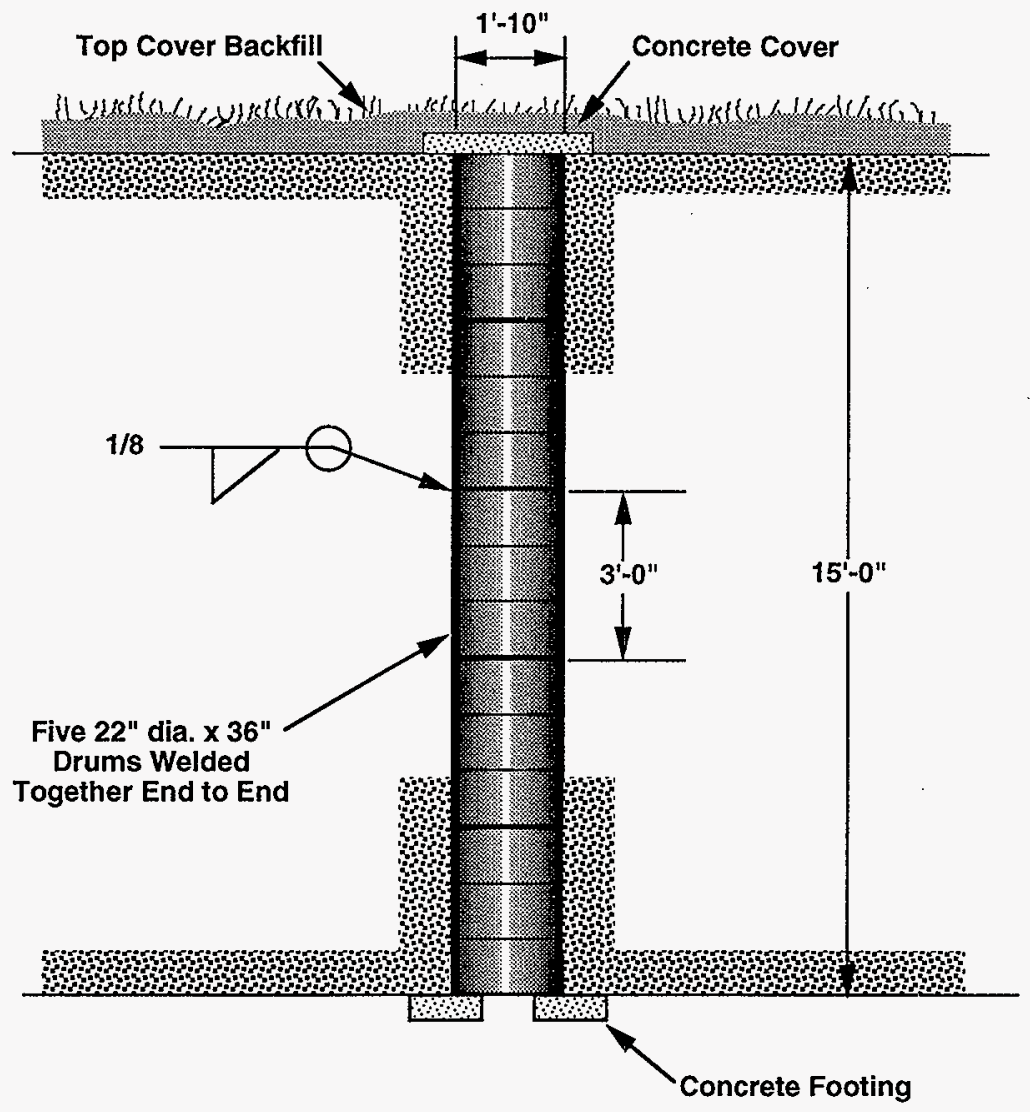




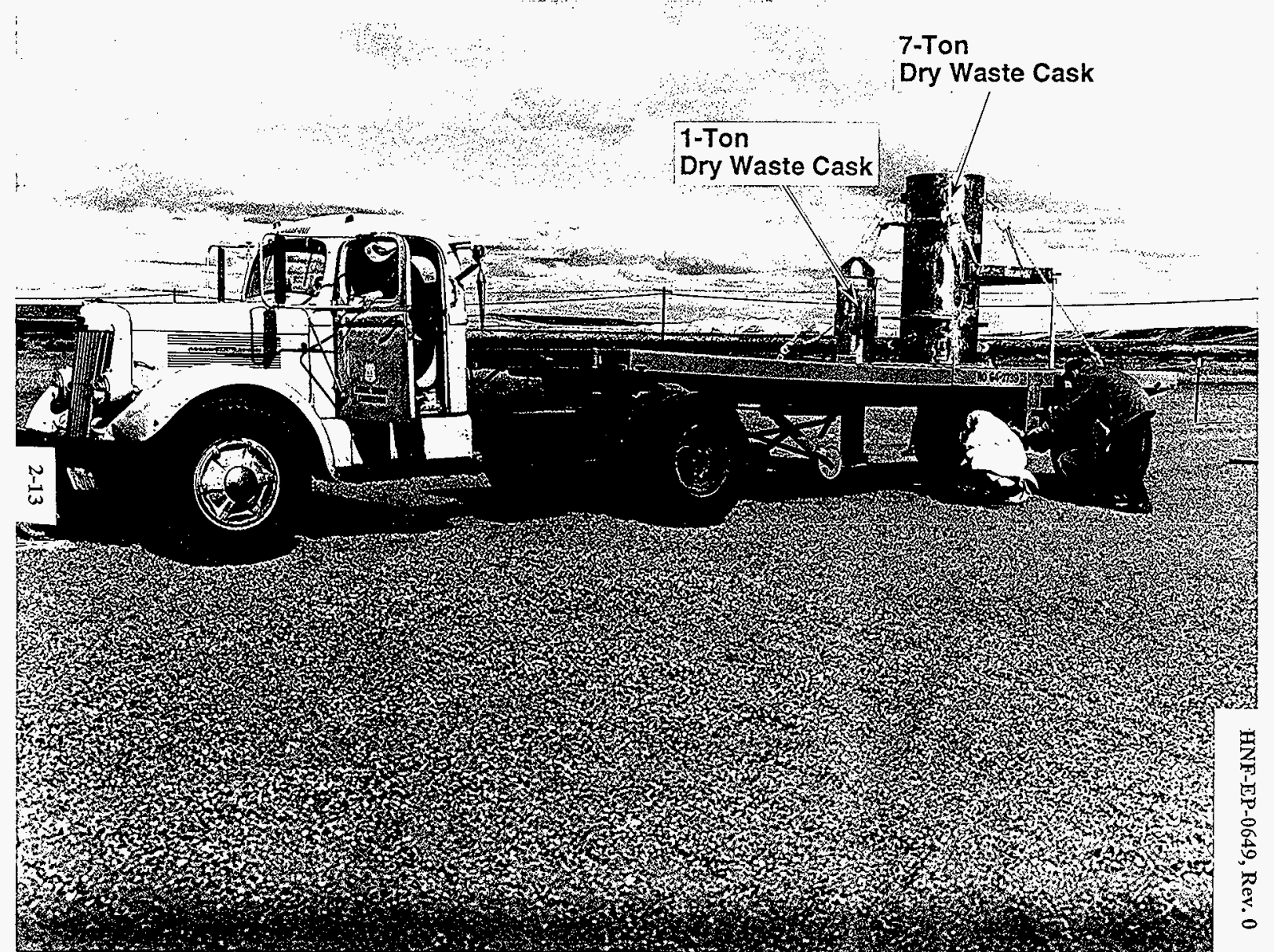


HNF-EP-0649, Rev. 0

Figure 2-10:

8 Foot Caisson

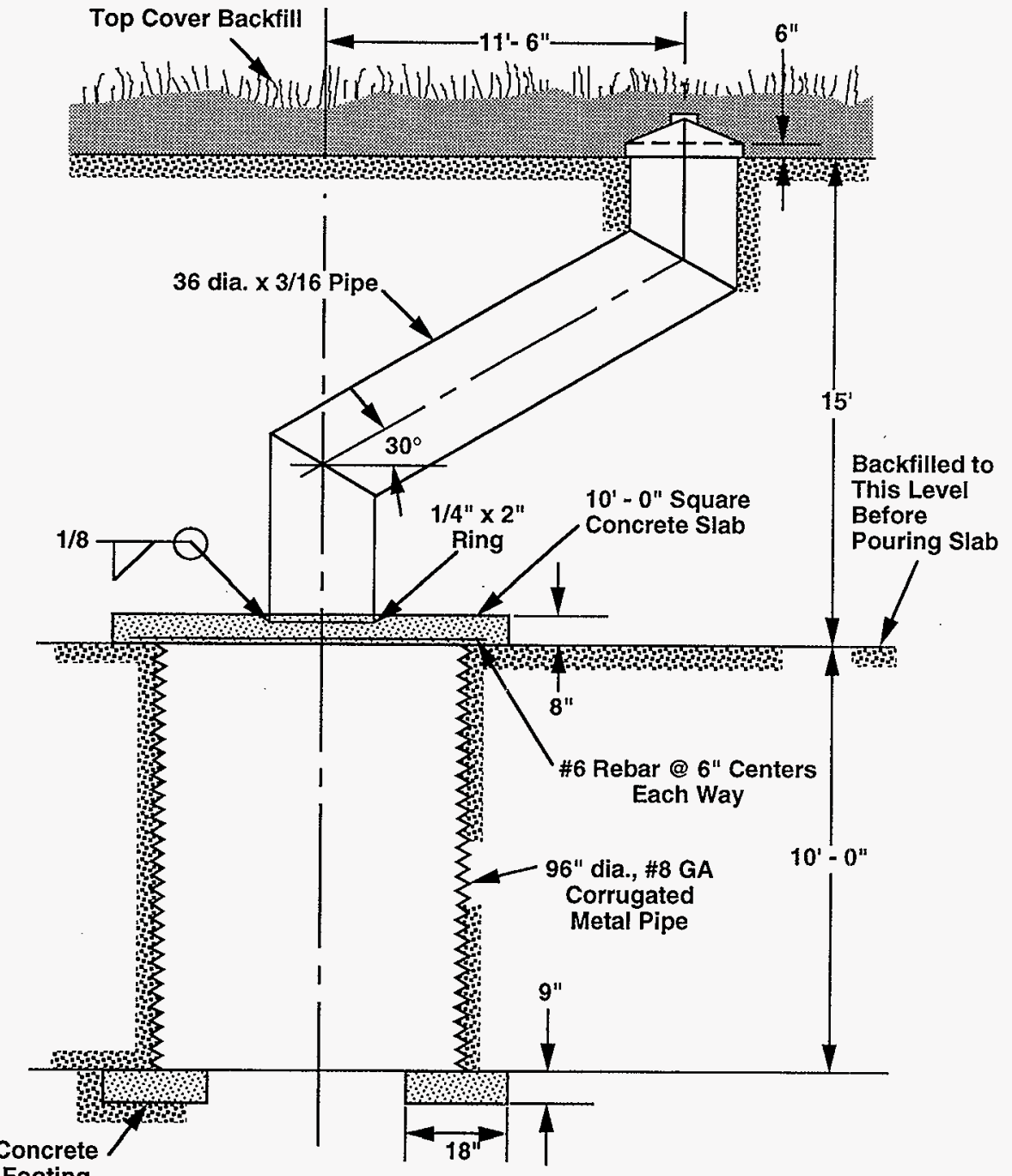

Footing 


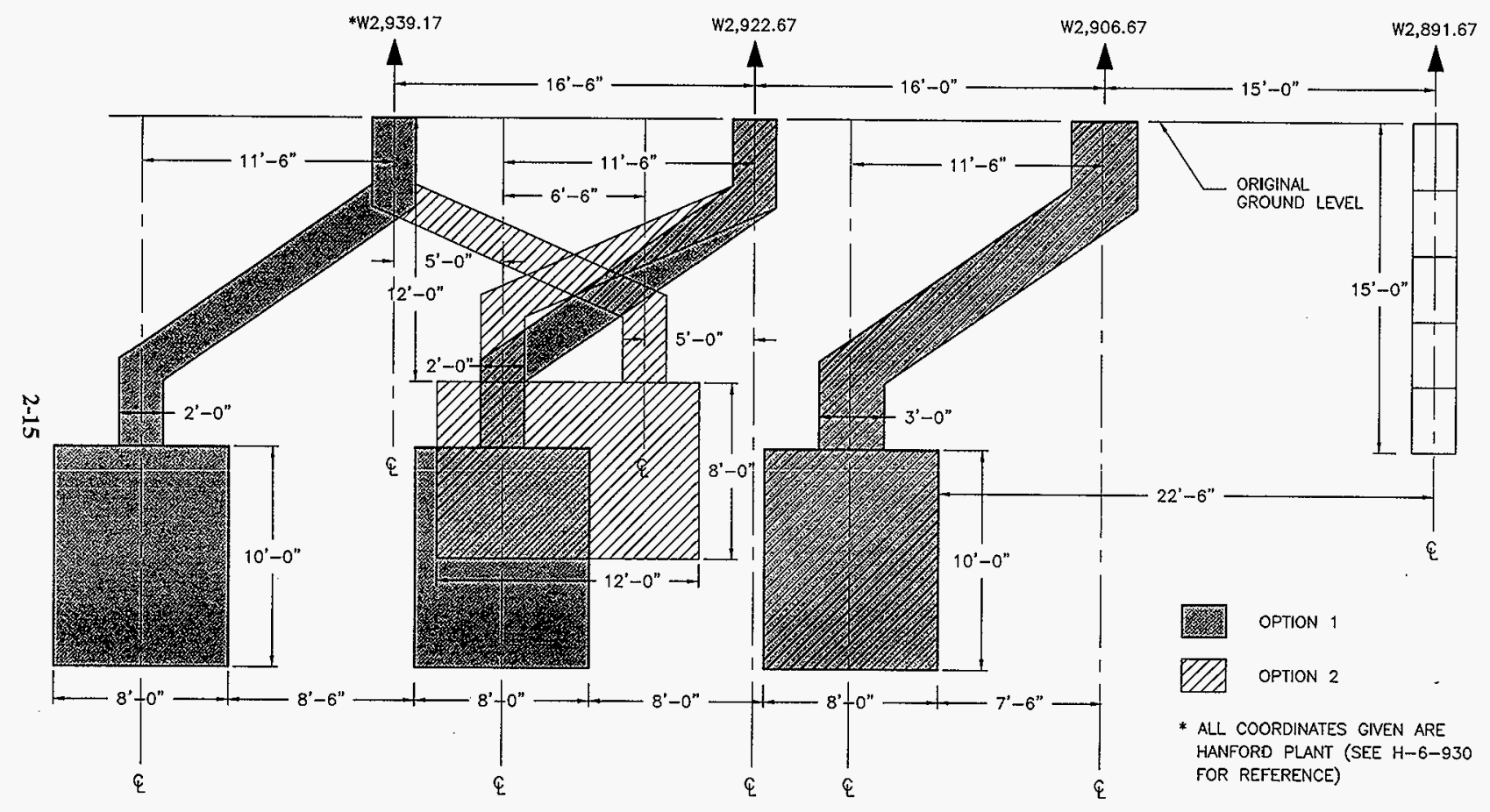

JD\092597A

FIGURE 2-11: POSSIBLE CAISSON LOCATION OPTIONS AT THE 618-11 BURIAL GROUND ALONG N12,428.24 BETWEEN W2,939.17 AND W2,906.67 


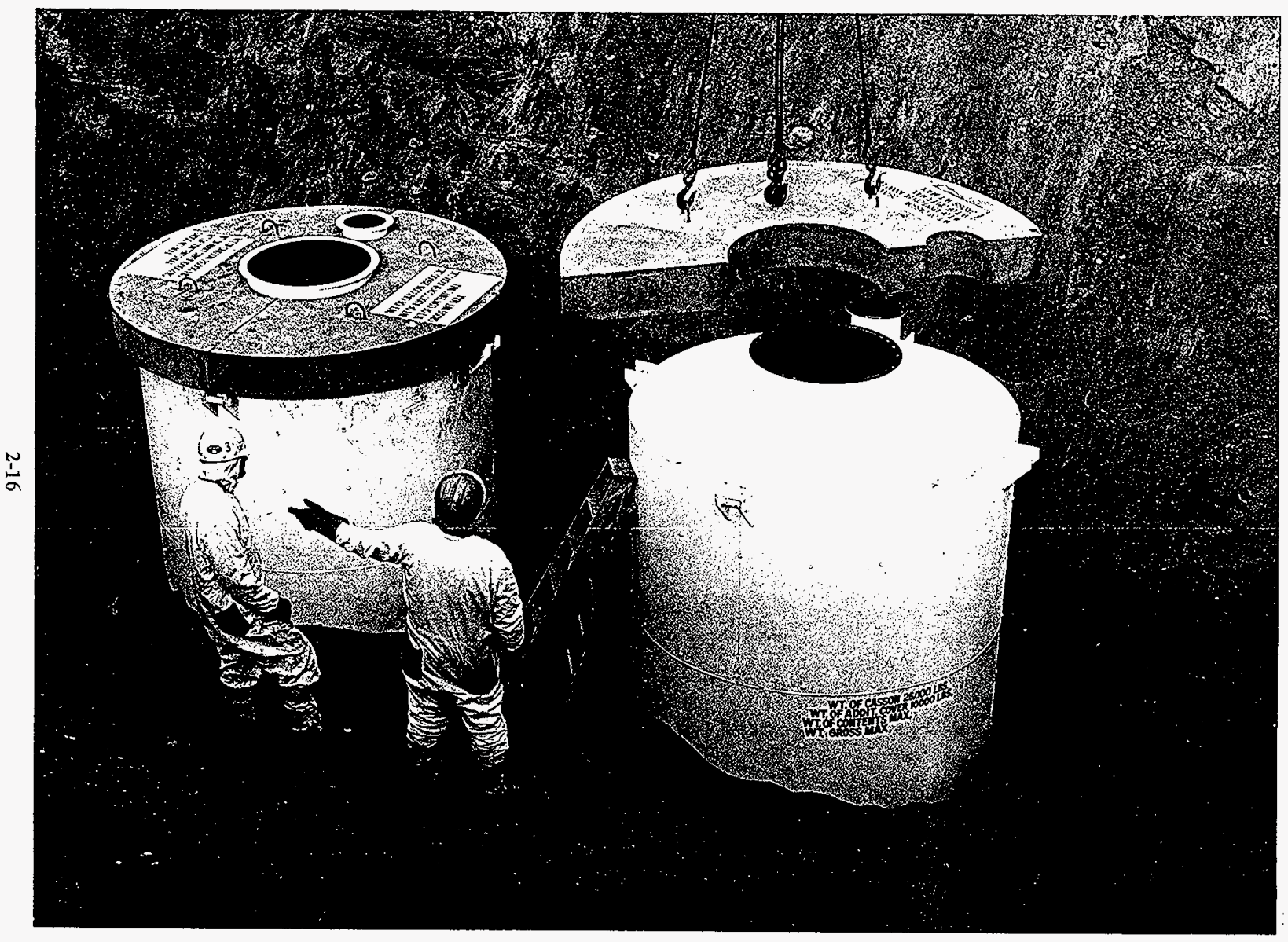


earth backfilling to the top of the caisson, the offset dump chute was installed. A similar 200 Area caisson placement is shown on Figure 2-13. The final 15 feet of earth fill was placed over the caisson to meet ground level. No bottom (except dirt) existed in the caisson units (Phillips 1980 and Graybeal 1964).

The first caissons installed at the burial ground, from June 1964 to August 1964, had 24 inch and 36 inch waste drop chutes. This is supported by: (1) the Backman (1964) reference, which states that they have had no problem in getting the waste boxes to travel to the bottom of the tanks; (2) Figure 2-3, showing two 24 inch outside diameter (O.D.) caisson pipe openings at $\mathrm{W} 2,939.17$ and $\mathrm{W} 2,922.67$, next to the three foot diameter caisson pipe opening at W2,906.67; (3) the enlarged photograph (Figure 2-14), which clearly shows the two most westerly caisson waste pipe openings at a substantially smaller diameter than the adjacent three foot caisson opening; and (4) the EMI done, (Phillips 1982 Bergstrom 1997) clearly shows three anomalies to the west of the drum storage units at W2,906.67 to W2,939.17 (Figures 2-15 and 2-16).

A discrepancy exists in the number of caissons at the W2,906.67 to W2,939.17 location. Although this document reports three caissons at that location, the number of caissons cannot be verified with complete confidence without further non-intrusive site evaluations that will be recommended in Section 8. Site drawings and EMI/GPR data (Bergstrom 1997) support three eight-foot diameter caissons at these coordinates, while the written information from monthly reports (GE 1962-1964) suggest one eight-foot diameter caisson and one double-chute twelvefoot caisson (Graybeal 1964). Interviews with Bob Hall and George Backman support the fact that all caissons were eight foot diameter. The caisson options located at these coordinates are shown in Figure 2-11. Section 2.5 will discuss in detaif the discrepancies contained in drawings and data conceming the site.

\subsubsection{Historical Timeline}

A historical timeline of the 618-11 site is given in Table 2-2. The timeline provides key dates in understanding the activities that transpired during the development of the burial ground. These documented activities provide a simple chronology of the burial ground which will aid in characterization. Each burial ground activity cited is supported by reference(s). Not all activities known to have occurred at the burial ground are given, i.e., not all contamination incidents are listed. Only activities that establish dates of operation, major construction start/completion, or understandings of operation philosophy are cited.

\subsubsection{Site Description Based on Hanford Drawings}

Drawing H-3-9951 (later renumbered H-6-930) is the only known Hanford drawing of the 618-11 burial ground. The drawing revisions were examined to determine the burial ground construction and operation sequence presented in Section 2.3. Only aperture cards for Revisions 2 through 7 of H-3-9951 and Revision 0 of H-6-930 could be located. The results of the examination of all available revisions of the drawings is given in Table 2-3. Copies of all revisions of the two drawings are provided in Appendix B. 
HNF-EP-0649, Rev. 0

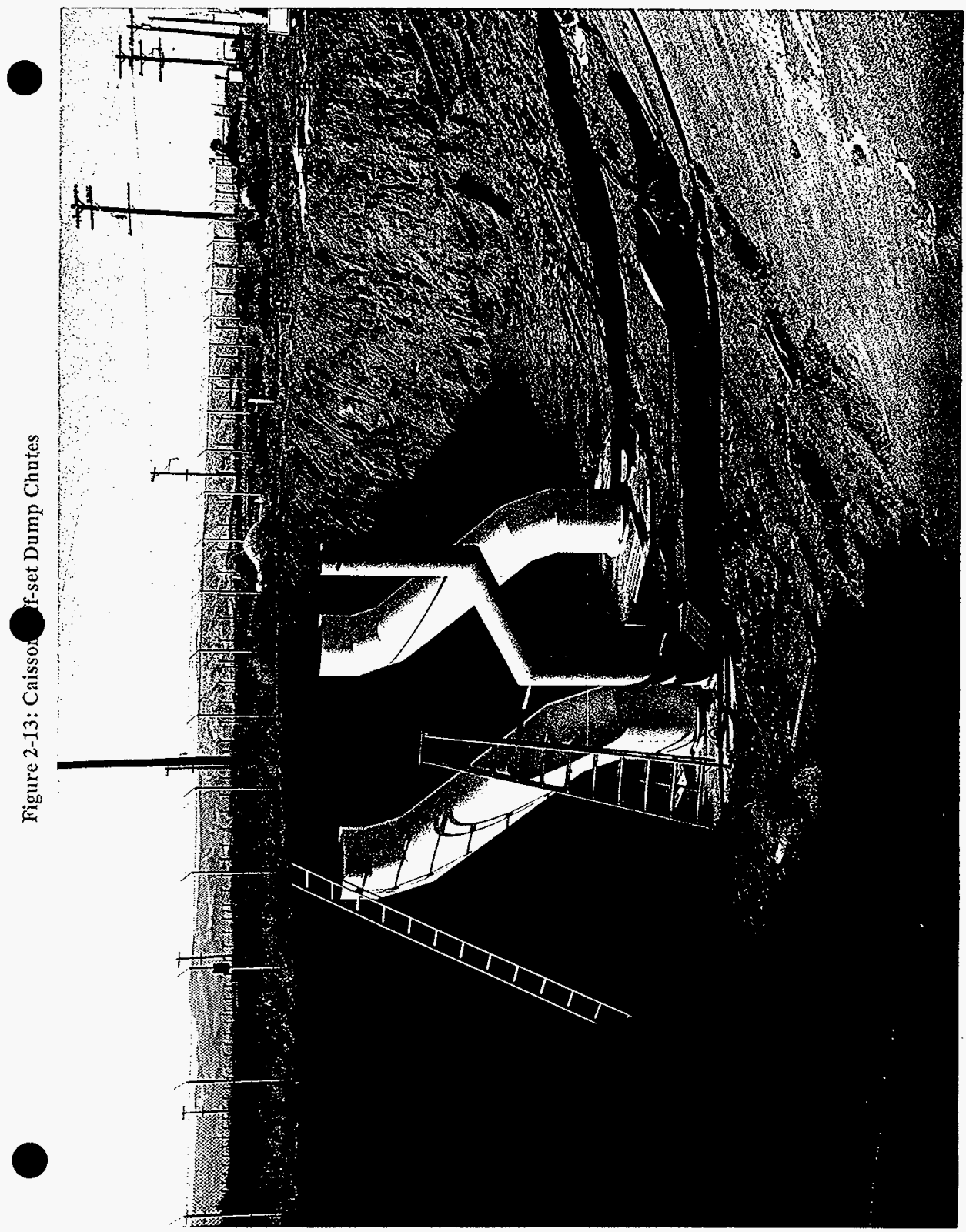




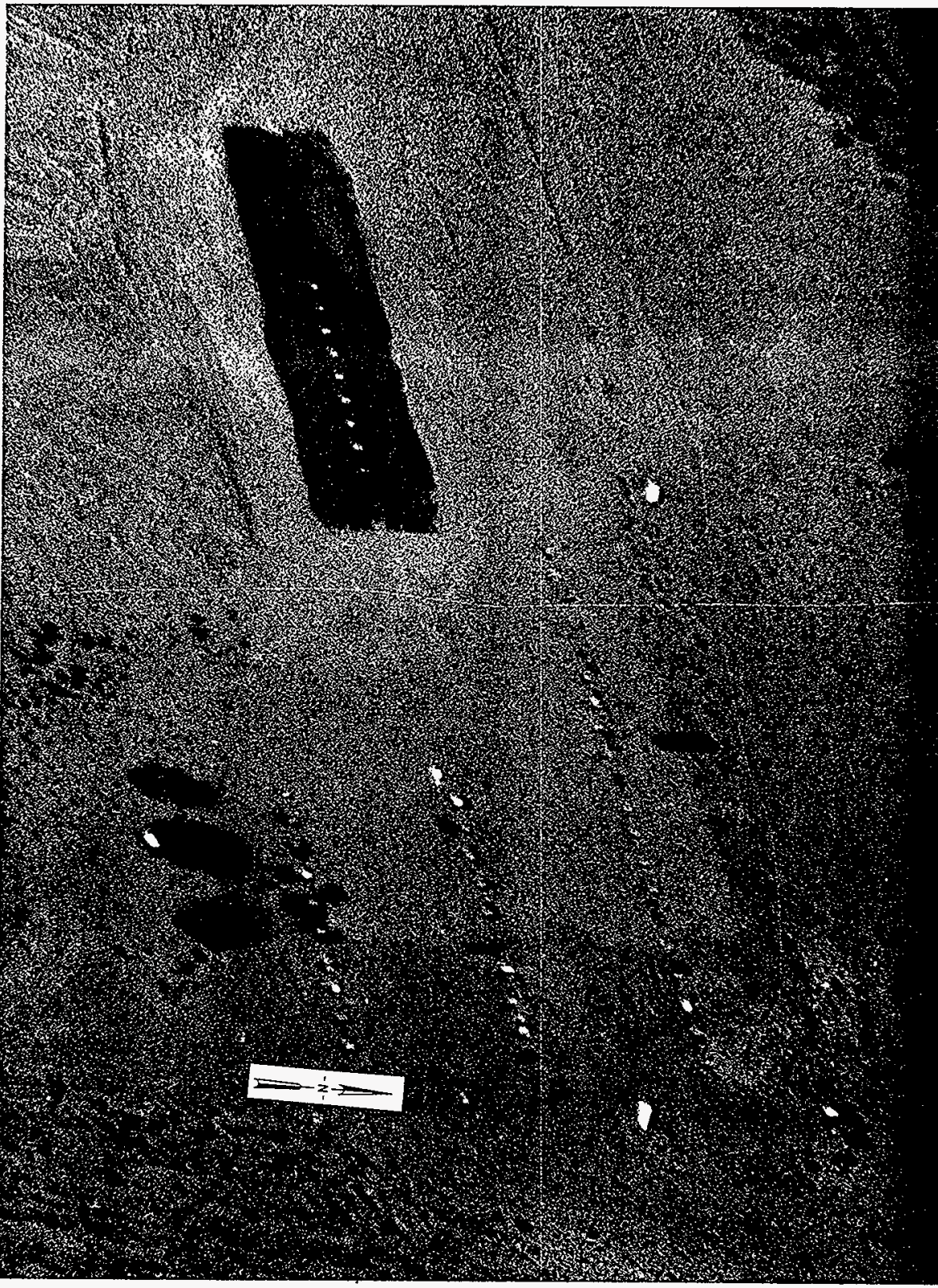




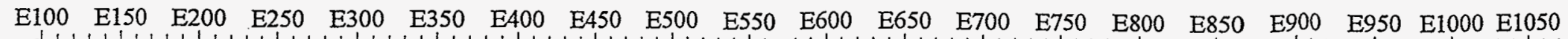

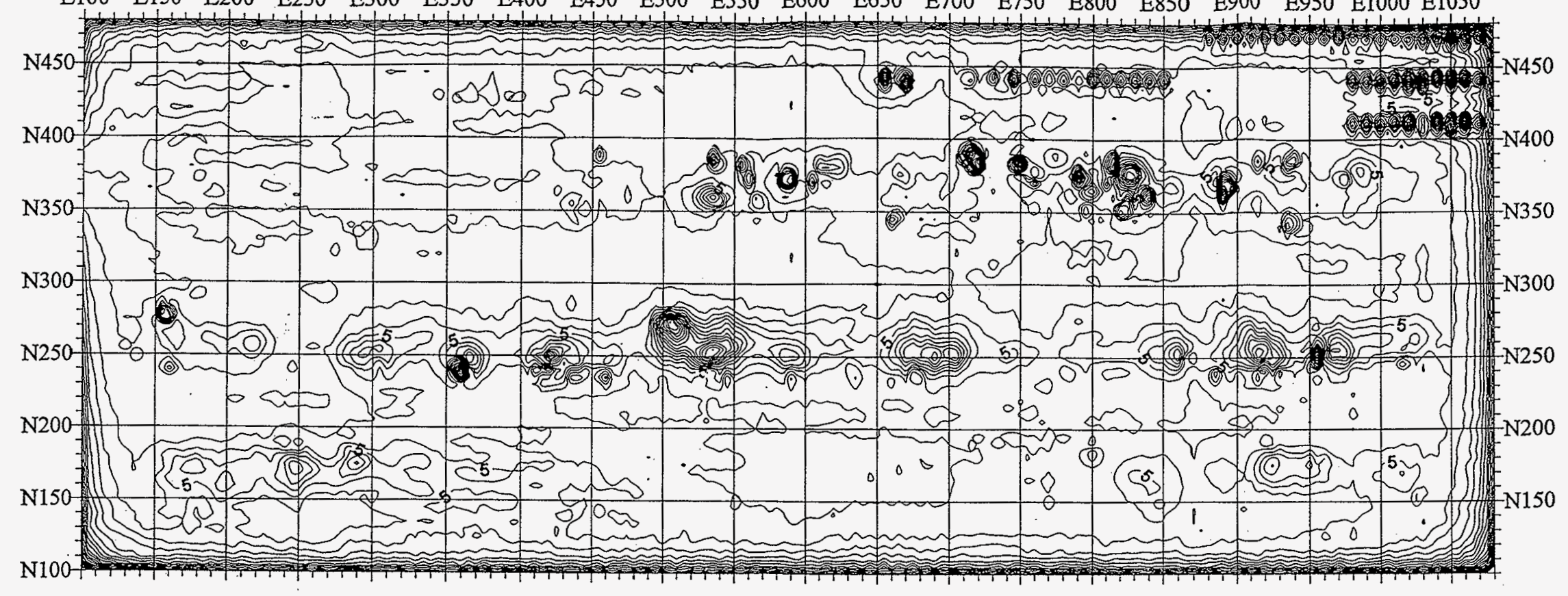

$\begin{array}{llllllllllllllllllllllll}\mathrm{E} 100 & \mathrm{E} 150 & \mathrm{E} 200 & \mathrm{E} 250 & \mathrm{E} 300 & \mathrm{E} 350 & \mathrm{E} 400 & \mathrm{E} 450 & \mathrm{E} 500 & \mathrm{E} 550 & \mathrm{E} 600 & \mathrm{E} 650 & \mathrm{E} 700 & \mathrm{E} 750 & \mathrm{E} 800 & \mathrm{E} 850 & \mathrm{E} 900 & \mathrm{E} 950 & \mathrm{E} 1000 & \mathrm{E} 1050\end{array}$

oft $50 \mathrm{ft}-10 \mathrm{ft}-150 \mathrm{ft} \quad 200 \mathrm{ft}$ 
Figure 2-16 Aerial View of Caisson/Drum Storage Units EMI Overlay Positions

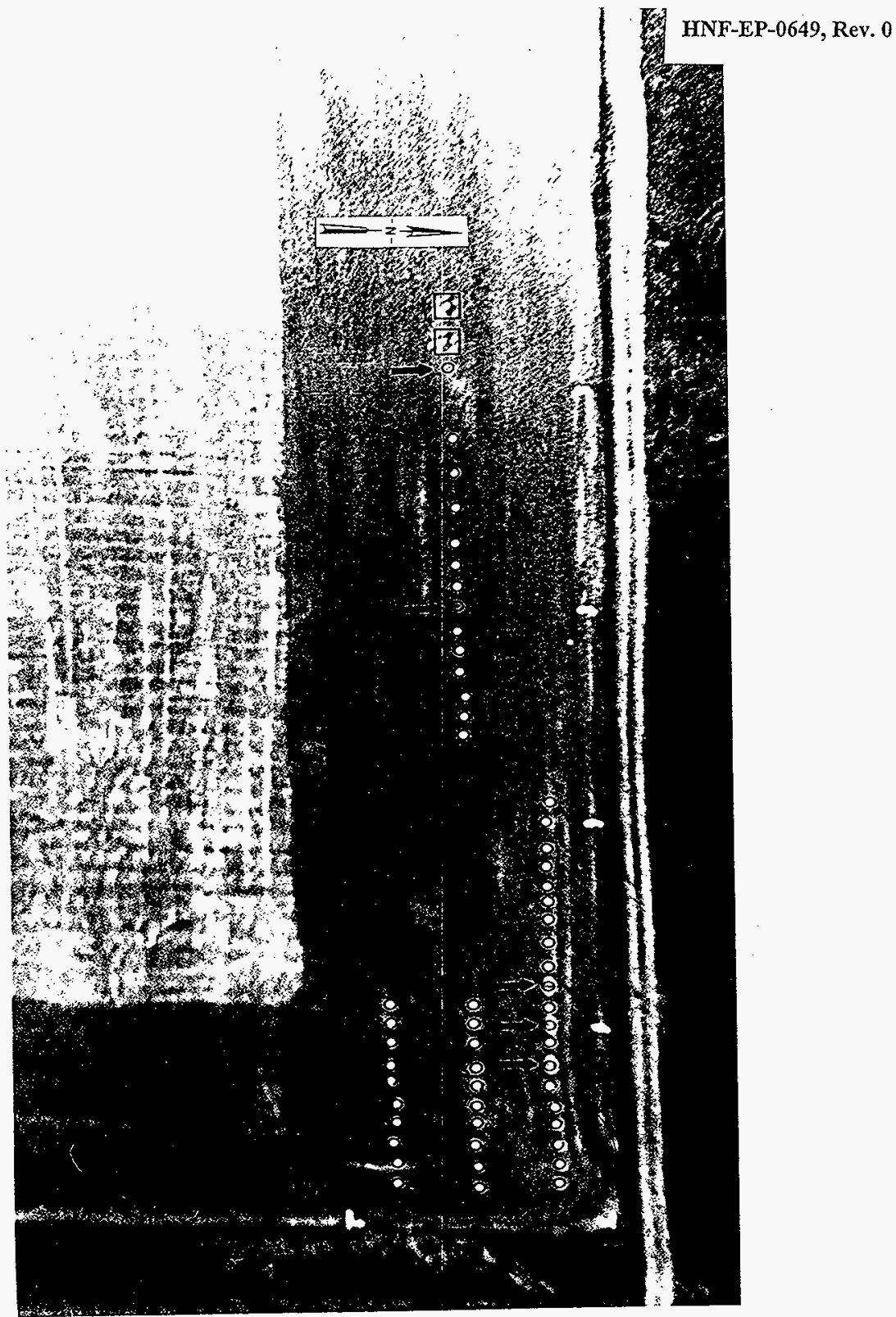


Table 2-2: 618-11 Burial Ground Historical Timeline

\begin{tabular}{|c|c|c|}
\hline Date & Activity & Reference \\
\hline $03 / 09 / 62$ & 618-11 trenches open & Appendix $\mathrm{F}$ \\
\hline $10 / 03 / 62$ & 618-11 closed pending AEC Review & HW-75376 (GE 1962-64) \\
\hline $04 / 15 / 63$ & $\begin{array}{l}1962 \text { summary: } 618-11 \text { first trench being filled; } 1 \mathrm{yr} \text { left } \\
\text { (a) } 618-10\end{array}$ & $\begin{array}{l}\text { HW-77274 (Backman } \\
\text { 1963a) }\end{array}$ \\
\hline $09 / 02 / 63$ & Contamination spread at $618-10$ & Appendix $\mathrm{H}$ \\
\hline $09 / 16 / 63$ & $618-10$ closed & HW-79046 (GE 1962-64) \\
\hline $09 / 16 / 63$ & $618-11$ receiving waste & HW-79046 (GE 1962-64) \\
\hline $09 / 24 / 63$ & Approximately 30 pipe units installed @618-11 & EA Berreth 1963 \\
\hline $09 / 30 / 63$ & Contamination spread at $618-10$ & Appendix $\mathrm{H}$ \\
\hline $01 / 10 / 64$ & Draft caisson drawings submitted & RG Graybeal 1964 \\
\hline $02 / 64$ & Designs for $618-11$ caissons being reviewed & HW-81019 (GE 1962-64) \\
\hline $03 / 06 / 64$ & 325 Bldg. 7-ton cask first run to drum units & Photo $\# 0640606$, Appendix A \\
\hline $03 / 06 / 64$ & Contamination spread at $618-11$ & Appendices $\mathrm{A}, \mathrm{H}, \mathrm{I}$ \\
\hline $06 / 64$ & $\begin{array}{l}\text { Two dry waste disposal tanks are being installed at } 300 \\
\text { Wye BG }\end{array}$ & HW-83000 (GE 1962-64) \\
\hline $07 / 64$ & $\begin{array}{l}\text { Installation of the two large waste disposal tanks at the } \\
300 \text { Wye BG will be completed } 8 / 64 \text {. }\end{array}$ & HW-83445 (GE 1962-64) \\
\hline $08 / 19 / 64$ & Shows 50 pipe unit tops $\&$ caisson openings & Photo \#37273-11 \\
\hline $09 / 64$ & $\begin{array}{l}\text { The large waste disposal tanks are in use at the } 300 \text { Wye } \\
\text { BG. To date, we have had no problems in getting the } \\
\text { waste boxes to travel to the bottom of the tanks. }\end{array}$ & HW-84291 (GE 1962-64) \\
\hline $10 / 14 / 64$ & The large disposal tanks at the 300 Wye are now in use. & GE Backman 1964 \\
\hline 1965 & 3 rd Trench added at $618-11$ & H-3-9951, Rev. 4 \\
\hline $06 / 19 / 67$ & Waste silos at $618-11$ will soon be filled & Corley 1967 \\
\hline $07 / 31 / 67$ & AEC seeking closure of $618-11$ & Hall 1967 \\
\hline $12 / 31 / 67$ & 618-11 Closed & Appendix E (Cadwell 1971) \\
\hline $03 / 12 / 68$ & Trenches have been backfilled & Corley 1968 \\
\hline $09 / 16 / 68$ & Site inspection to meet $\mathrm{AEC}$ closure requirements. & Hall 1968 \\
\hline $02 / 11 / 74$ & Request for fence and gate & ARCO 1974 \\
\hline $07 / 25 / 74$ & Fence/gate work completion and acceptance & JA Jones 1974 \\
\hline $04 / 82$ & Site surface stabilization & $\begin{array}{l}\text { Conklin 1982, WHC 1983, } \\
\text { Bracken } 1982\end{array}$ \\
\hline
\end{tabular}


Table 2-3: 618-11 Burial Ground Drawing Revisions Examination

\begin{tabular}{|c|c|}
\hline Revision Number & Dates and Data \\
\hline $\begin{array}{l}\text { Revision 2, H-3-9951, Sheet } \\
1 \text { of } 1\end{array}$ & $\begin{array}{l}\text { - } \\
\text { - } \\
\text { Issuevision Date } 7 / 31 / 63 \\
\text { Released for construction } 7 / 31 / 63 \\
\text { - Shows trenches only; } \# 1 \text { and } \# 2 \text { are labeled \& another } 12 \text { are phantomed } \\
\text { in. }\end{array}$ \\
\hline $\begin{array}{l}\text { Revision 3, H-3-9951, Sheet } \\
\text { I of } 1\end{array}$ & $\begin{array}{l}\text { Revision date } 9 / 25 / 63 \\
\text { - } \quad \text { Signed and approved } 10 / 10 / 63 \\
\text { Shows the addition of } 40 \text { drum storage units, none to the west end. }\end{array}$ \\
\hline $\begin{array}{l}\text { Revision 4, H-3-9951, Sheet } \\
1 \text { of } 3\end{array}$ & $\begin{array}{l}\text { - Revision date } 1965 \text { only } \\
\text { Signed and approved } 4 / 21 / 66 \\
\text { Entitled: "Burials to date" } \\
\text { Shows } 10 \text { more drum storage units to the west ( } 50 \text { total) and the three } \\
\text { "waste burial facility vent lid' caissons added to the west of the last } \\
\text { drum storage units. The "waste burial facility" is the same title RG } \\
\text { Graybeal used in his } 1 / 10 / \text { drawins (Ref. } 26 \text { ). The three "vent lids" show } \\
24 \text { " OD, } 24 \text { " OD, and } 36 \text { " OD respectively. } \\
\text { Trench } 3 \text { is added. }\end{array}$ \\
\hline $\begin{array}{l}\text { Revision } 5, \mathrm{H}-3-9951 \text {, Sheet } \\
1 \text { of } 1\end{array}$ & $\begin{array}{l}\text { Rev. } 5 \& 6 \text { are different than Rev. 7. Rev. } 7 \text { appears to be older with } \\
\text { additional data not shown, or changed on Rev. } 5 \text { \& } 6 \text {. } \\
\text { The microfilmed Rev. } 5 \text { bears a } 2 / 16 / 68 \text { date (after } 618-11 \text { closure), but } \\
\text { on Rev. } 7 \text { (H-3-9951, Sheet } 2 \text { of } 3 \text { ), the } \\
\text { Rev. } 5 \text { bears a } 5 / 17 / 65 \text { date. It was signed off and approved } 8 / 3 / 66 \text {. } \\
\text { Rev. } 7 \text { appears to be the reliable source for correct history of the } 618-11 \text {. } \\
\text { Nothing was really done other than combining the three sheets from } \\
\text { Rev. } 4 \text { into one sheet (although Rev. } 7 \text { states that Rev. } 5 \text { expanded the } \\
\text { drawings to three sheets). }\end{array}$ \\
\hline $\begin{array}{l}\text { Revision } 6, H-3-9951 \text {, Sheet } \\
1 \text { of } 1\end{array}$ & $\begin{array}{l}\text { Nothing is stated but gate \& fence added, with a } 3 / 9 / 74 \text { date (after } \\
\text { closure). } \\
\text { But using the Rev. } 7 \text { entry, a revision date of } 8 / 24 / 65 \text { is given, with the } \\
\text { wording "additional containers" As in this revision, both large } \\
\text { caisssons are shown between W3008.67 and W2997.17. }\end{array}$ \\
\hline $\begin{array}{l}\text { Revision 7, H-3-9951, Sheet } \\
2 \text { of } 3\end{array}$ & $\begin{array}{l}\text { - Shows a revision date } 8 / 3 / 66 \text {, and an approval date of } 8 / 3 / 66 \text {, with the } \\
\text { statement, "checked for as-builts." } \\
\text { - This revision will be used as the standard for Rev, } 5 \& 6 \text { data and dates }\end{array}$ \\
\hline $\begin{array}{l}\text { Revision } 0, \mathrm{H}-6-930 \text {, Sheet } 1 \\
\text { of } 1\end{array}$ & $\begin{array}{l}\text { Was a redraw of H-3-9951, Rev. 6, which gives it the " } 6 \text { " designation } \\
\text { for facilities outside the } 100,200,300 \text {, and } 400 \text { Areas. }\end{array}$ \\
\hline
\end{tabular}


The original drawing was made, checked, and classified November 10,1961. Seven revisions were made to Drawing H-3-9951. The first recorded revision is dated July 31, 1963 (Revision 2). It is identified as the only sheet, and gives a general layout of 14 trenches. The two northern most trenches are numbered as Trenches \#1 and \#2, and site coordinates are listed. Revision 1, which apparently changed site coordinates for the burial ground, was signed off November 29, 1961, but no copy was found.

Revision 3, dated September 25, 1963, has the locations of 40 "upright multiple metal drums," in three rows with the rows designated for the 327,325 , and 309 buildings. The north row $(N 12,456.24)$ containing 20 units was assigned to the 327 building. The middle row (N12,428.24) containing 10 units was assigned to the 325 building. The south row $(\mathrm{N} 12,398.24)$ containing 10 units was assigned to the 309 building. These drum storage units are in the northeast corner of the burial ground, as shown on the current H-6-930 drawing. The first errors were introduced into the drawings at this revision (Section 2.5). The installation of the 40 drum storage units is supported by the September 23, 1963 Berreth reference (Berreth 1963) and the drawn locations of the drum storage units are supported by the site EMI characterization (Figure 2-15).

Revision 4, dated simply "65" at the revision block, split the drawing into three sheets, labeled Trench \#3, added 10 more drum storage units, and added three caissons. It is believed that the 10 drum storage units and the three caissons were installed at the same time between June 1964 and August 1964, prior to the August 16, 1964 site aerial photograph (Figure 2-5). These additional drum storage units started at 130 feet west (W2,801.67) of the last drum storage units in the center row $(\mathrm{N} 12,428.24)$. The revision addition of three "waste burial facility vent lids" (later shown as offset drop chute caissons, Revision 5) were installed west of the 10 drum storage units from W2,906.67 to W2,939.17.

The microfilmed versions of Revisions 5 and 6 show revision dates after the closure of the burial ground. Revision 7, however, has different revision dates and descriptions for Revisions 5 and 6. The revision dates and descriptions of $5 / 17 / 65$ for Revision 5 and 8/24/65 for Revision 6 contained on Revision 7 coincide with known events of the burial ground during its operation. The revision descriptions and dates contained on the microfilmed Revisions 5 and 6 coincide with known event after the burial ground closure. Revisions, 5, 6 and 7, contain supportive burial ground data but Revision 7 provides the needed descriptive data to support characterization. For example, Revision 7 description title of Revision 6 shows "additional containers" and is dated $8 / 24 / 65$. This is the only date found that provides information concerning the installation of the last two caisson units between W2,993.67 and W3,008.67.

This drawing evaluation clearly shows that Trench $\# 1$ and Trench $\# 2$ were the first burial facilities built at the 618-11 burial ground. The two trenches were followed by construction of 40 drum storage units in September 1963 (Berreth 1963). The construction of an additional 10 drum storage units, and three caissons were added prior to August 1964 (Figures 2-7 and 2-14), and is supported by the 1965 date on Revision 4. In 1965 Trench \#3 and the final two caissons were added, as detailed in Revisions 4 and 7 . The final two caissons are shown stradding the north-south centerline $(\mathrm{W} 3,000.00)$ of the burial ground. 
There are several errors contained in the drawings (discussed in detail in Section 2.5). However, the Hanford drawings do provide a valuable resource to the burial ground characterization. Combining the data in the Hanford drawings with written references and photographic data, provide a credible burial ground characterization package.

\subsection{OPERATIONAL HISTORY}

The 618-11 burial ground operated from March 9, 1962 until October 3, 1962, and again from September 16, 1963 until it was closed permanently on December 31, 1967.

The site contains a broad spectrum of low-level dry waste including fission products, by-product material (thorium and uranium), and plutonium. The site was used for the disposal of 300 Area laboratory solid wastes. Low-activity wastes were received from the following facilities: $303,305,306,309,313,321,324,325,325-\mathrm{A}, 325-\mathrm{B}, 326,327,329,333,340$ Complex, 3706, 3707-C, 3718, 3730, and 3732. Some 1100 Area waste material was also received. These facilities all handled radioactively contaminated, or potentially contaminated, waste from operations or laboratory areas, including the hot cell areas. Moderate and highactivity (remote-handled) wastes were received from the 327 radiometallurgy hot cells, $325-\mathrm{A}$ hot cells, the 325-B (analytical) hot cells, occasionally from the PRTR - 309 building, and later from the 324 hot cells. The low to moderate activity dry solid wastes were disposed to trenches and moderate to high-activity wastes were disposed to drum storage units and caissons. Some exceptions to this general rule did exist. The 325-A hot cells disposed of moderate and highactivity wastes to the trenches in concrete/lead-shielded drums (Keene 1961). The 325-B hot cells also used concrete shielded drums to dispose of hot cell waste (including cleanup debris), used laboratory containers and glassware, and spent instruments and equipment. In addition, plutonium residues were encapsulated in concrete, and placed in lead and concrete shielded drums at the 325 building by the 340 building operators servicing various organizations and facilities, including the 308 building.

Trench \#1 was the first waste burial structure constructed at the site. Backman (1964) states that "In accordance with instructions from the AEC, use of the "Wye" burial ground will be continued only until the capacity of the trench is exhausted." This is interpreted to mean the northern most trench, labeled Trench \#1 (Figure 2-6). It was not until September 24, 1963 that any mention of placing drum storage units in the burial ground was made (Berreth 1963). Backman (1963) cautions that more 300 Area facilities are now working with plutonium, in addition to mixed fission product (MFP) type radionuclides. Backman proposed plutonium segregation, and caution in using the new WYE burial ground facility for its disposal.

Backman also suggested following the AEC recommendation to close the $300-\mathrm{N}$ burial ground as a "contamination control measure" (Backman 1963a). The AEC was beginning to recognize the importance of public perception of AEC's operation and control of government installations around the United States. If a large contamination spread was to occur at the 300-N burial ground, the only Hanford Site access road may be closed. At this same time a new 
highway, State Highway 240 (the McCormack highway) was being constructed through the southwest quadrant of the Hanford Site. The AEC believed the agency would be found negligent if it made no effort to control radioactive contamination releases to the general public. It was under this scrutiny that the decision was made to close the $300-\mathrm{N}$ burial ground. Evaluations were also began to consider the future of the 618-11 burial ground.

Trench wastes included concrete and lead shielded 55-gallon drums, nonshielded 55, 30, and 15-gallon drums or cans, spent control waste system (CWS, later called high efficiency particulate air HEPA) filters, wooden boxes, cardboard cartons, and failed equipment. Highly penetrating beta/gamma waste, including TRU radionuclides, was buried in the shielded drums. Cardboard carton wastes were typically small items contaminated with MFP, by-product, and TRU radionuclides such as rubber gloves, cloth and paper wipes, plastic sheeting and liners, masking tape, and failed or used equipment. Steel drums or cans were often used for large, heavy, or sharp tools or failed equipment, and for contaminated lead bricks or shielding. Some wooden boxes were used to dispose of contaminated lead bricks and shielding pieces, broken non-irradiated fuel pieces, and other metal waste. The CWS were typically wrapped or lined with plastic and placed in the original cardboard container used by the manufacturer. Items including both CWS and laboratory waste, typically read from a few $\mathrm{mR} / \mathrm{hr}$ to $500 \mathrm{R} / \mathrm{hr}$ at contact (Appendix A). The cartons with high dose rates were typically placed in the middle of the carton stack to reduce worker exposure.

Caissons were the last burial structures placed at the 618-11 burial ground. Because of high radiation doses (beta/gamma shine) from vertical drum storage units, offset chute designs were conceived. The recorded caisson design drawings are dated January 10, 1964 (Graybeal 1964).

Caisson wastes included much of the same waste materials, but radiation readings were in the thousands, to tens of thousands, $\mathrm{R} / \mathrm{hr}$ at contact. The caisson wastes were typically sectioned in hot cells using master slave manipulators so the waste components could fit into smaller waste disposal canisters. Canisters used included metal paint cans, five-gallon buckets, and slip-lid metal cans with tape seals; etc. The cans were sealed, crimped, or closed and loaded into casks for shipment to the burial ground.

The radioactive and other hazardous materials known, or suspected to have been buried at the site included solid metallic sodium; beryllium residues; contaminated metallic lead shielding; technetium oxide; promethium oxide (very soft energy beta, hard to detect); zirconium cladding material; potentially ignitable metal turnings; thorium oxide; other thorium compounds; enriched, normal, and depleted uranium compounds; and MFP materials. Radionuclides known, or suspected to be present include $\mathrm{C}^{14}, \mathrm{Co}^{60}, \mathrm{Zn}^{65}, \mathrm{Sr}^{90}, \mathrm{Ru}^{103}, \mathrm{I}^{131}, \mathrm{Cs}^{137}, \mathrm{Ce}^{144}, \mathrm{Pm}^{147}, \mathrm{Ra}^{226}, \mathrm{Th}^{232}$, $\mathrm{U}^{233}, \mathrm{U}^{235}, \mathrm{~Np}^{237}, \mathrm{U}^{238}, \mathrm{Pu}^{238}, \mathrm{Pu}^{239}, \mathrm{Pu}^{240}, \mathrm{Am}^{241}$, and $\mathrm{Cm}^{244}$. The $\mathrm{Pu}^{240}$ content was typically $6 \%$ (weapons grade), but later PRTR test fuel was produced with up to $12 \% \mathrm{Pu}^{240}$. Residues of that fuel were thought to be disposed at 618-11. Numerous other fission products are present as well as salt residues from salt cycle work $(\mathrm{KCl}, \mathrm{NaCl}$, etc.). Fuel residues would be mostly oxides, but could include metals and metal alloys, carbides, nitrides, carbonitrides, and halides from the salt cycle work. 
The 618-11 burial ground was permanently closed on December 31, 1967. The entire burial ground was backfilled and covered with four feet of soil. Perimeter radiation concrete posts ( $1.5 \mathrm{~m}$ high and $0.3 \mathrm{~m}$ in diameter) were fitted with stamped brass radiation hazard markers that included topographical coordinates. These markers installed in 1968 are shown in Figure 2-4 (Cadwell 1971, Corley 1968 and Hall 1967). Radiation surveys taken in the early 1980 s showed continual ground contamination at the site. The 1983 Site Assessment indicated the site was stabilized by grading and backfilling with two more feet of soil (WHC 1983) Stabilization was completed June 9, 1982. Immediately following stabilization, the site was seeded with crested wheat grass and irrigated for six weeks. The present contour of the site varies from about one to four feet above the surrounding grade (Figure 2-17).

\subsection{DISPOSAL ACTIVITIES}

Appendix $\mathrm{C}$ describes some of the standard low-activity containers that were used to dispose of the 300 Area wastes to the 618-11 burial ground. Cardboard cartons and other low-level activity wastes were collected and placed in load luggers. The containers (boxes, load luggers, and drums) were loaded on a flatbed truck trailers and transported to the burial ground for disposal. Containers with higher dose readings were loaded near the tail of the trailer so they were further from the driver and the first to be offloaded. Drivers transporting high-activity radioactive shipments sometimes switched at a mid-point to control the personnel dose of the driver. The load lugger contents were dumped into the trenches using a lift/dump mechanism on the flatbed. Wooden boxes and drums were off-loaded using a motor crane or similar device.

Appendix A addresses several cardboard cartons that read up to $500 \mathrm{R} / \mathrm{hr}$ at contact. Some of these high-activity cartons contained CWS filters used for cleaning the hot cell discharge air. Later, concrete filter burial boxes were procured as shielded container packages for high-activity CWS filter waste. 
HNF-EP-0649, Rev. 0

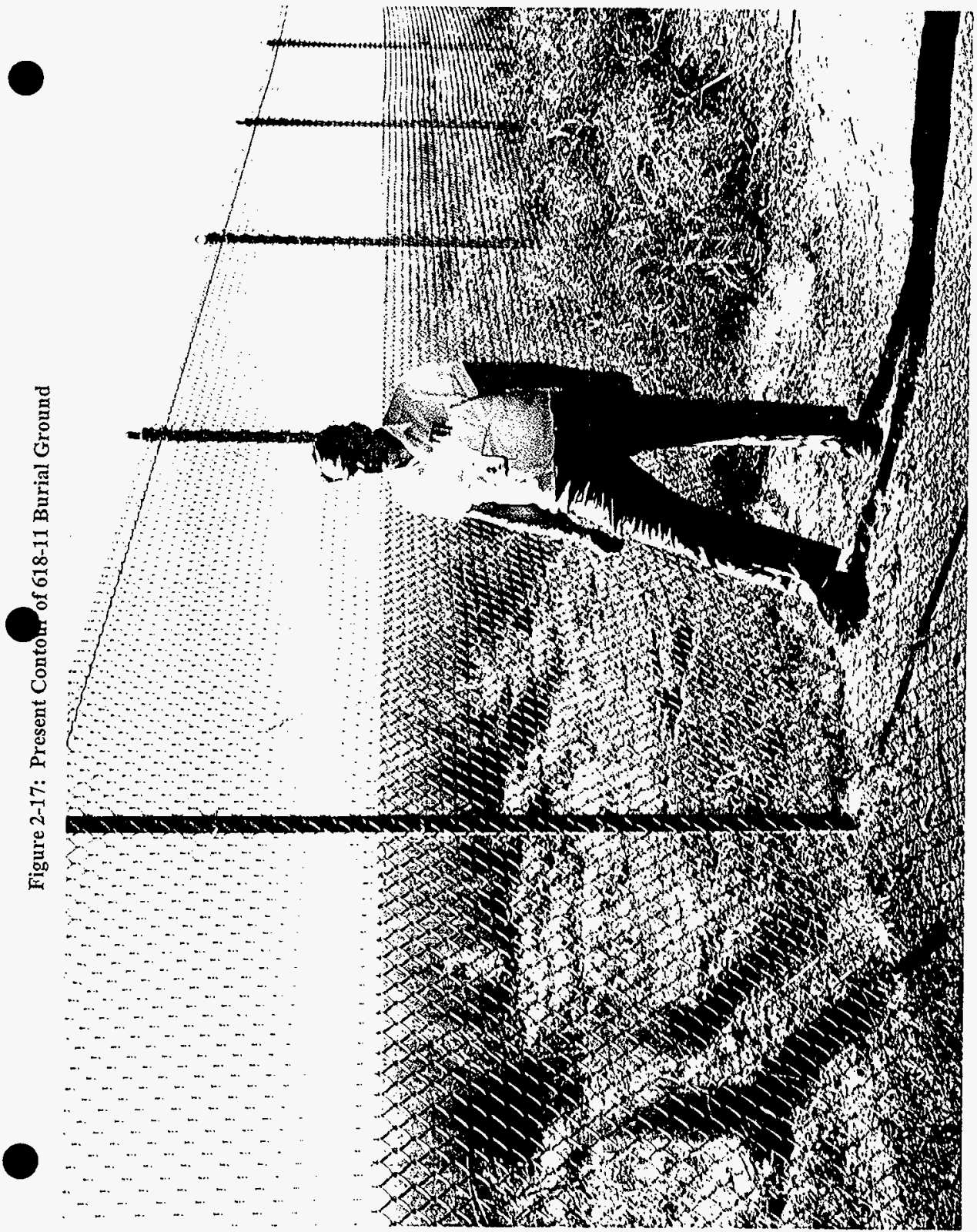


During this same time period, unshielded cartons were removed from the hot cells using a leaded cave. The four-sided cave (front and bottom removed) was set on the forks of a forklift and an empty carton slid inside the lead cave. The forklift was driven up to the hot cell where a port covering had been removed. The carton was then filled with waste items or the CWS filter from the cell. The fork lift was moved away from the cell and the cell port covering was reinstalled. The carton was closed and taped shut. The employee closing and taping the carton received a high dose rate. The box was then transported to the load lugger and shoved off the forks.

Figure 2-18 clearly shows a load of cardboard boxes disposed at the west end of Trench \#2. A bulldozer shoved the spoil pile into the trench and drove over it as the trench filled, similar to Figure 2-19. Trench waste was covered with a minimum of four feet of soil.

Trucks, unloading waste, and other heavy equipment drove over filled trenches (Figures 2-19 and 2-20). Activities at the 618-11 burial ground seemed to parallel these early trench waste-fill activities. The cardboard boxes and wooden boxes would have been badly damaged. Subsequent failures of the containers could cause trench subsidence to be a problem.

Reducing the volume of the waste void by various methods was suggested to control subsidence following burial ground closure. It was feared subsidence might cause wastes to be exposed (Backman 1963a). It appears that subsidence was a primary issue in the design of caissons (Gerber 1992). However, it should be noted that without accurate container type, exact location, and waste records, conclusions or corrective measures to subsidence issues are difficult (Kibbe 1992). Caisson and burial container static and live-load stresses were more carefully considered in the design of waste containers after several subsidence problems occurred in other burial grounds (Shirley 1980). This occurred, however, after drum storage units and trenches were filled at the 618-11 burial ground. No drum failure analyses, whether caused by corrosion or static soil loading, have been found for 618-11 storage containers.

Hanford Site soil corrosion rates of steel drums in direct soil contact show a general corrosion rate of two to six mil/year (Duncan 1992). New-condition, well-painted drums exhibit the minimal corrosion rate while reconditioned or surface-damaged drums exhibit the maximum corrosion. Pitting corrosion rates are more aggressive, ranging from 3.5 to $9 \mathrm{mil} /$ year. The 53 mil (0.053 inches ) nominal walls of the typical U.S. Department of Transportation (DOT) $17 \mathrm{H}$ or $17 \mathrm{C}$ drums are expected to have lost integrity. Since these are the drums used to build the drum storage units, the structure of the unit itself is considered lost. 
Figure 2-18: Cardboard Boxes in Trench \#2

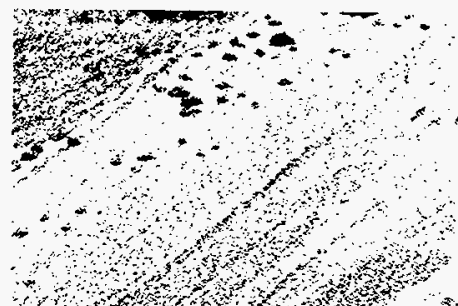

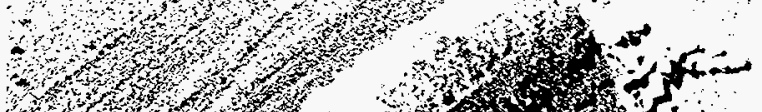
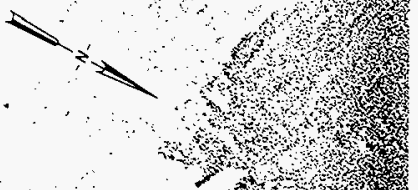

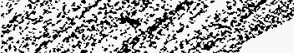

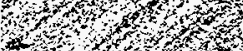

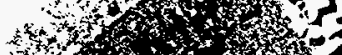
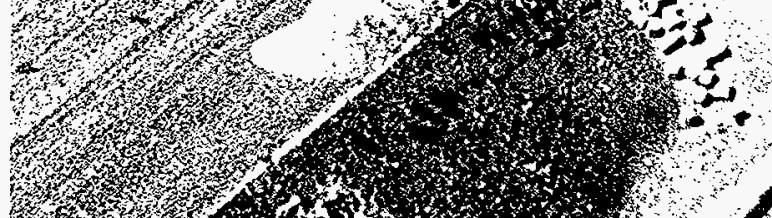

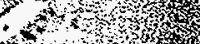

- 1

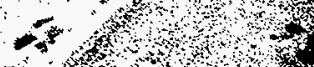

tist.

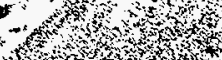

x
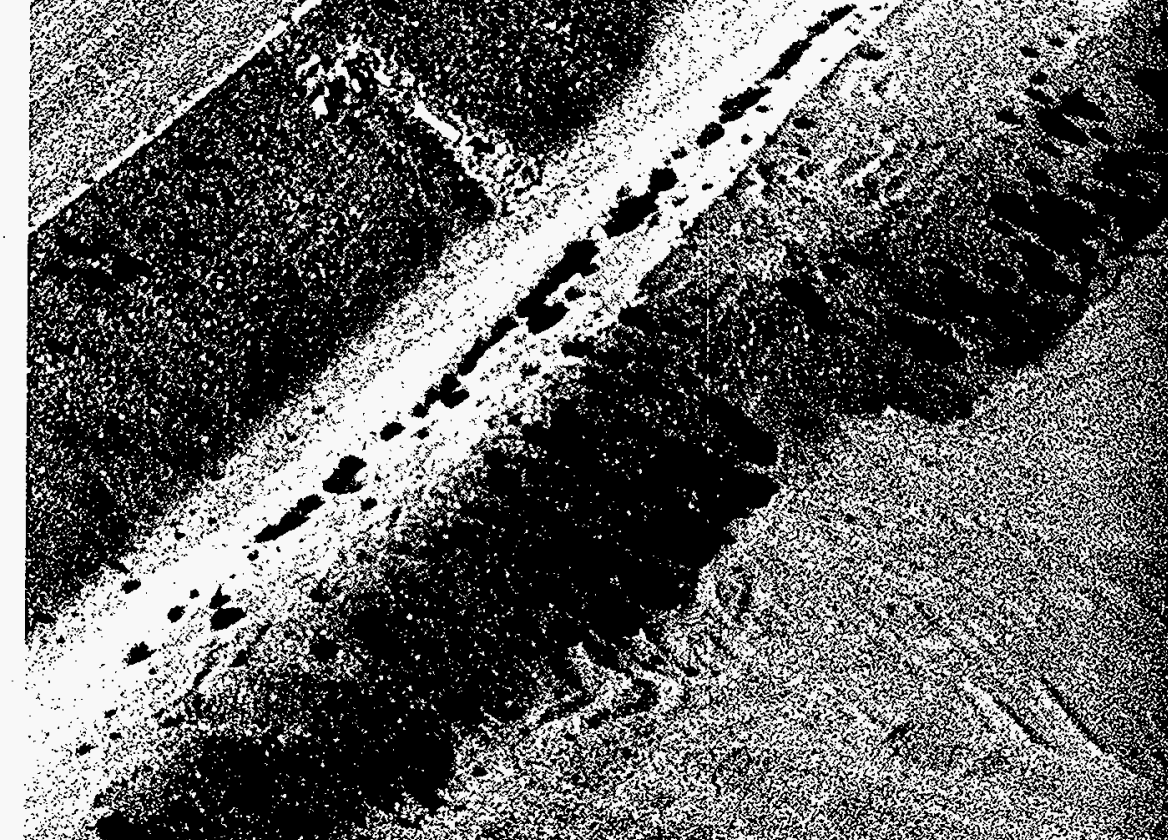

ar,

$x, 3$

$+$

(i)

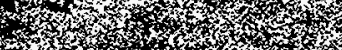

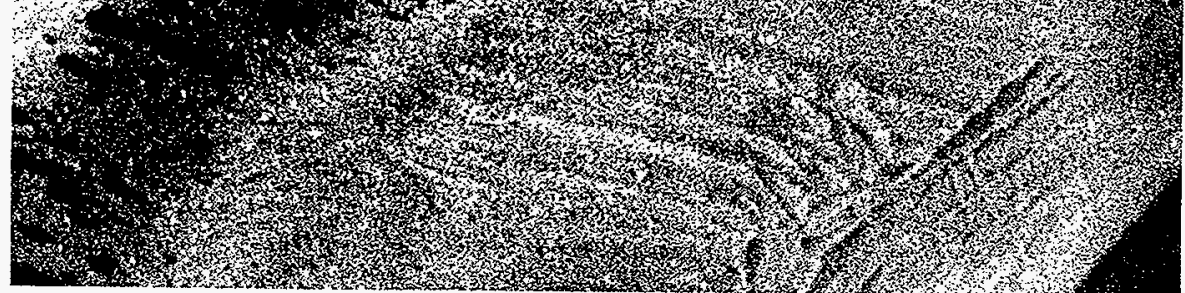




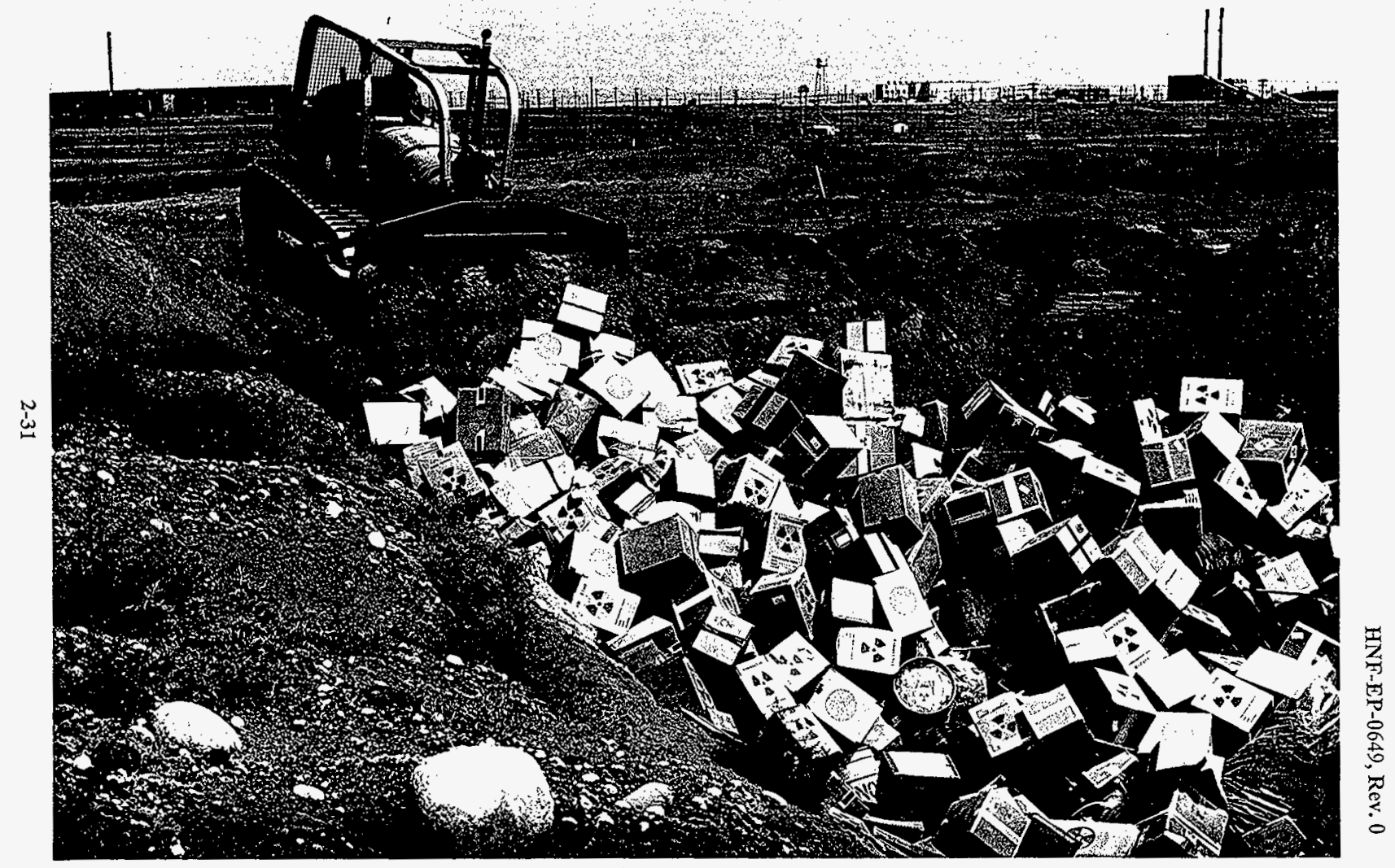




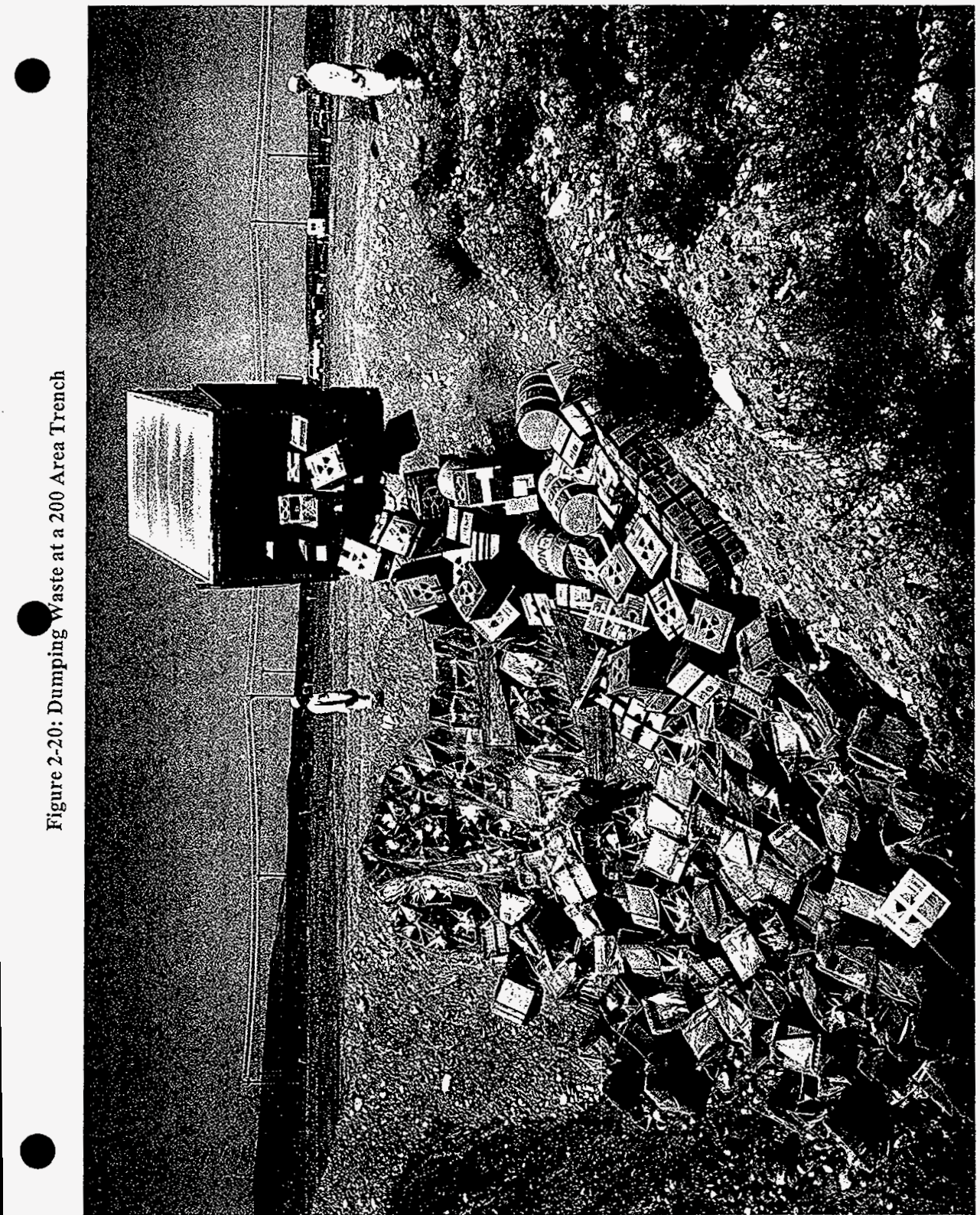


Before September 1963, all high and moderate-activity waste that could not be trench disposed was sent to the 618-10 burial ground for disposal in the drum storage units. This minimized radiation exposure to drivers and other waste workers. Milk pail and gatling gun cask wastes were first disposed in the 618-11 drum storage units from the 327 radiometallurgy building in September 1963 (Appendix E and Berreth 1963). Casks wastes from the 325-A building radiochemistry hot cells were disposed to the 618-11 drum storage units in one-ton and seven-ton casks beginning in January and March 1964, respectively (Appendices A and E).

The intermediate and high-activity wastes were transported to the 618-11 burial ground on specifically designed flatbed trucks. Casks were mounted on the bed with dump chutes installed through the bed as waste discharge channels. The drum storage units and caissons were filled beginning at the east and proceeding west. (This was opposite of trench fill). Figures 2-9 and 2-21 depict the initial cold run of the 325-A cask hauling truck. The truck was to go through the "standard run" with the new seven-ton and one-ton casks to check mounting elevation, clearance, and operability. After these photographs were taken on March 6,1964, a15-gallon black iron can was shipped to the 618-11 burial ground in the seven-ton cask. The disposal of the 15-gallon can in a drum storage unit caused a contamination spread (Appendices $\mathrm{A}, \mathrm{H}$ and $\mathrm{I}$ and GE 1962-1964).

Once the truck was positioned over the correct drum storage unit, the waste could be discharged. Figure 2-22 shows the standard waste dump operation. The operator and the radiation monitor removed the drum storage unit lid by pulling the center ring strap pin up to release the four hooks that held the lid on, and opened the cask bottom waste chute door. The operator would then pull the cask locking lever mechanism back and the waste containers would be discharged into the drum storage unit.

The radiation monitor would stand with his instrumentation to monitor radiation "shine" as the waste discharged, as shown in Figure 2-22. Typical shine or flash beta/gamma discharge doses would be one to five $\mathrm{R} / \mathrm{hr}$ out of the drum storage unit. Discharge doses from the offset caisson chutes were significantly less. Otherwise, the only difference between waste discharges into caissons versus drum storage units was that caissons had hinged lids instead of removable ones.

Repeated discharge of moderate and high-activity waste into drum storage units continued until the following conditions were reached:

- Dose at ground level reached a predetermined operational level, usually $15 \mathrm{R} / \mathrm{hr}$.

- The drum storage unit was full.

- Particulate contaminants were found outside the top of the unit being filled as a result of container integrity problems, or from dispersal of previously disposed waste caused by blowback or mishandling.

When one of the fill-completion criteria was met, the drum storage unit was capped with a concrete plug. The next waste discharges would occur at the drum storage unit to the west of the completed unit. Waste spills at discharge did happen. Figure 2-23 shows lids jarred off 
five-gallon paint cans as they hit the concrete bottom of the eight-foot diameter corrugated steel caisson. The waste caisson shown is a typical beta/gamma type unit located in the 200 West Area. The waste container fall distance is about the same as for the $618-11$ caissons ( $25 \mathrm{ft}$.), but the caisson in Figure 2-23 has a concrete floor; 618-11 caissons had earthen floors.

Figures 2-24, 2-25, and 2-26, as well as Figure 2-23 show containerized high-activity wastes disposed to caissons in the 200 West Area. The photographs were taken over 13 years. The photographs demonstrate the relatively intact condition of the waste containers in caissons. The 618-11 caissons differ from those shown in these figures in that they have a dirt bottom instead of concrete, so localized container corrosion may occur. After 33 years of corrosion to the drum storage units, it is surmised the units no longer have integrity. Therefore, waste canisters disposed to the drum storage units can not be expected to appear as those shown in the four figures. The concrete cap placed in and on top the drum storage unit at closure will add stability to the top of the unit, keep water intrusion low from the six weeks of watering the site at stabilization, but did introduce moisture to accelerate internal corrosion. Corrosion is expected to accelerate at each weld joint, perhaps breaking the unit apart. No subsidence has been reported at the drum storage unit areas (See Section 6.2). 


\section{7-Ton \\ Dry Waste Cask}

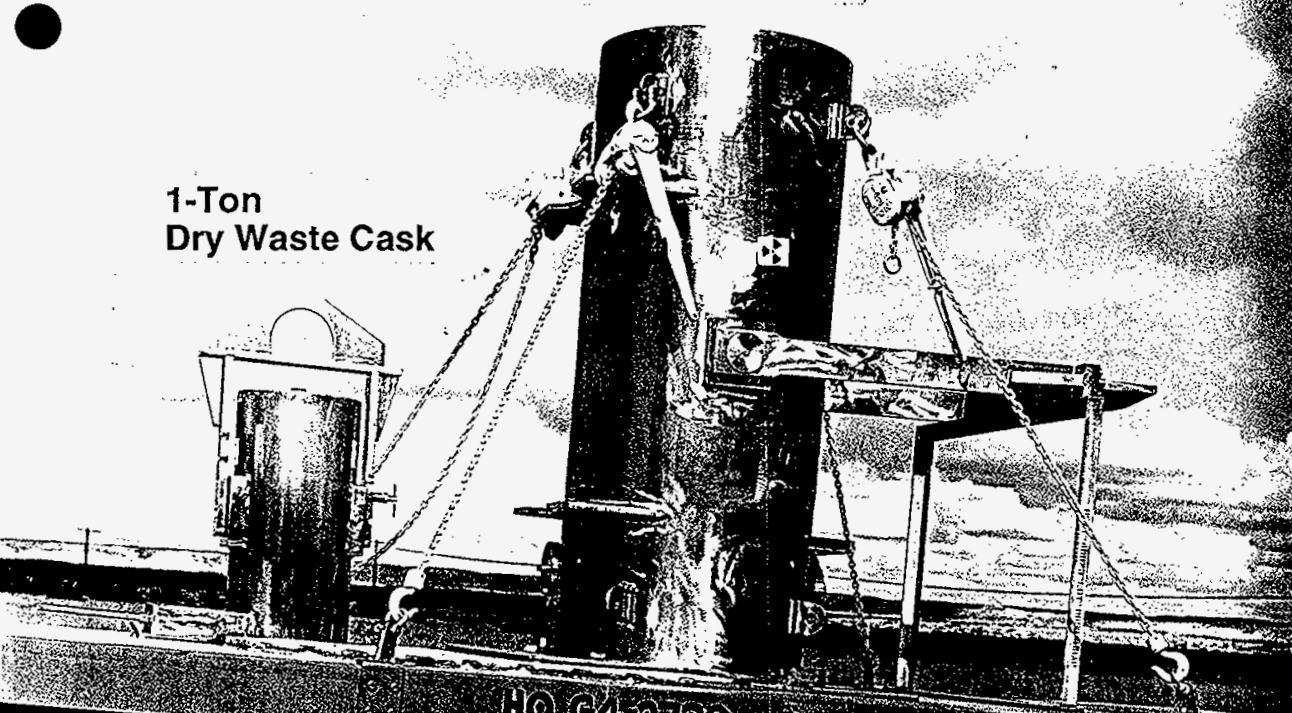

$10)(40780$

3
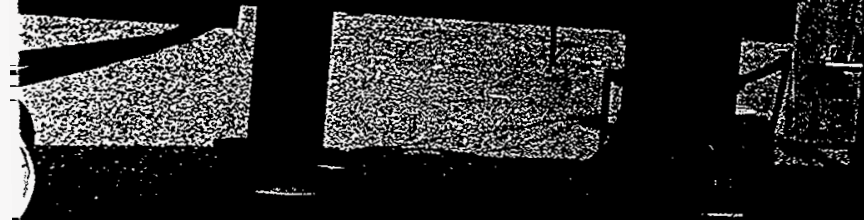

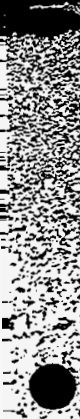

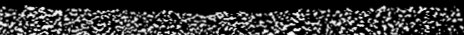

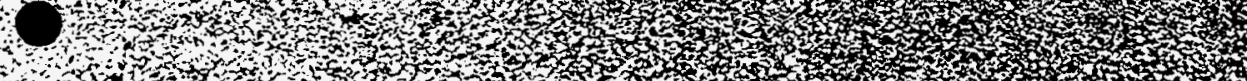

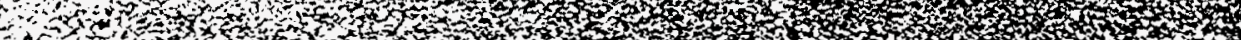

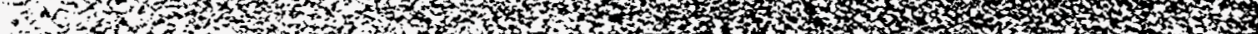

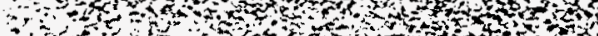

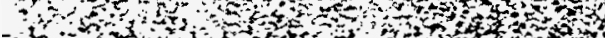


Figure 2-22: Cask Dump Operation

\section{7-Ton Cask Used for 5-Gallon and 15-Gallon Black Iron and 15-Gallon Stainless Steel Resin Can}

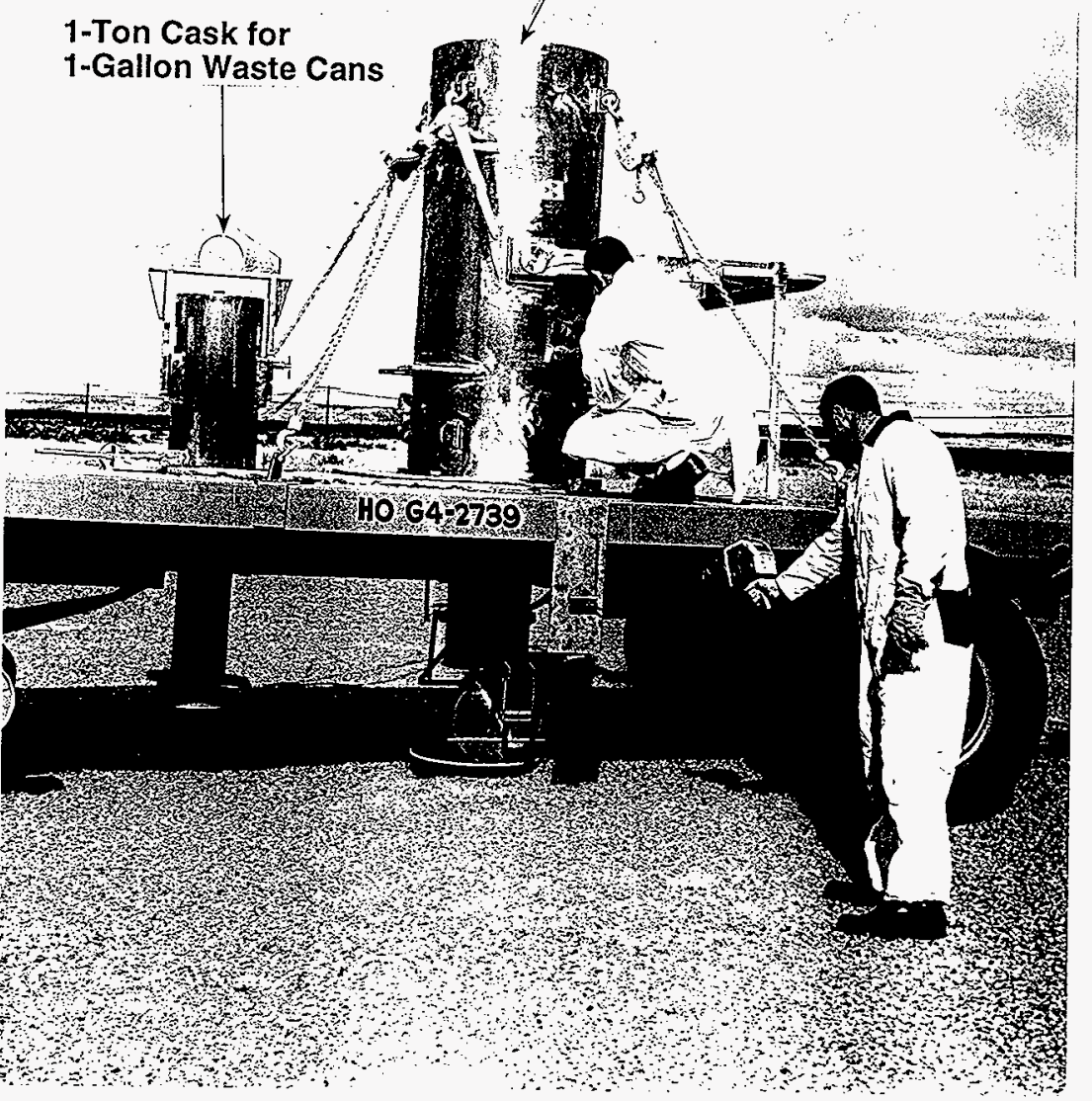




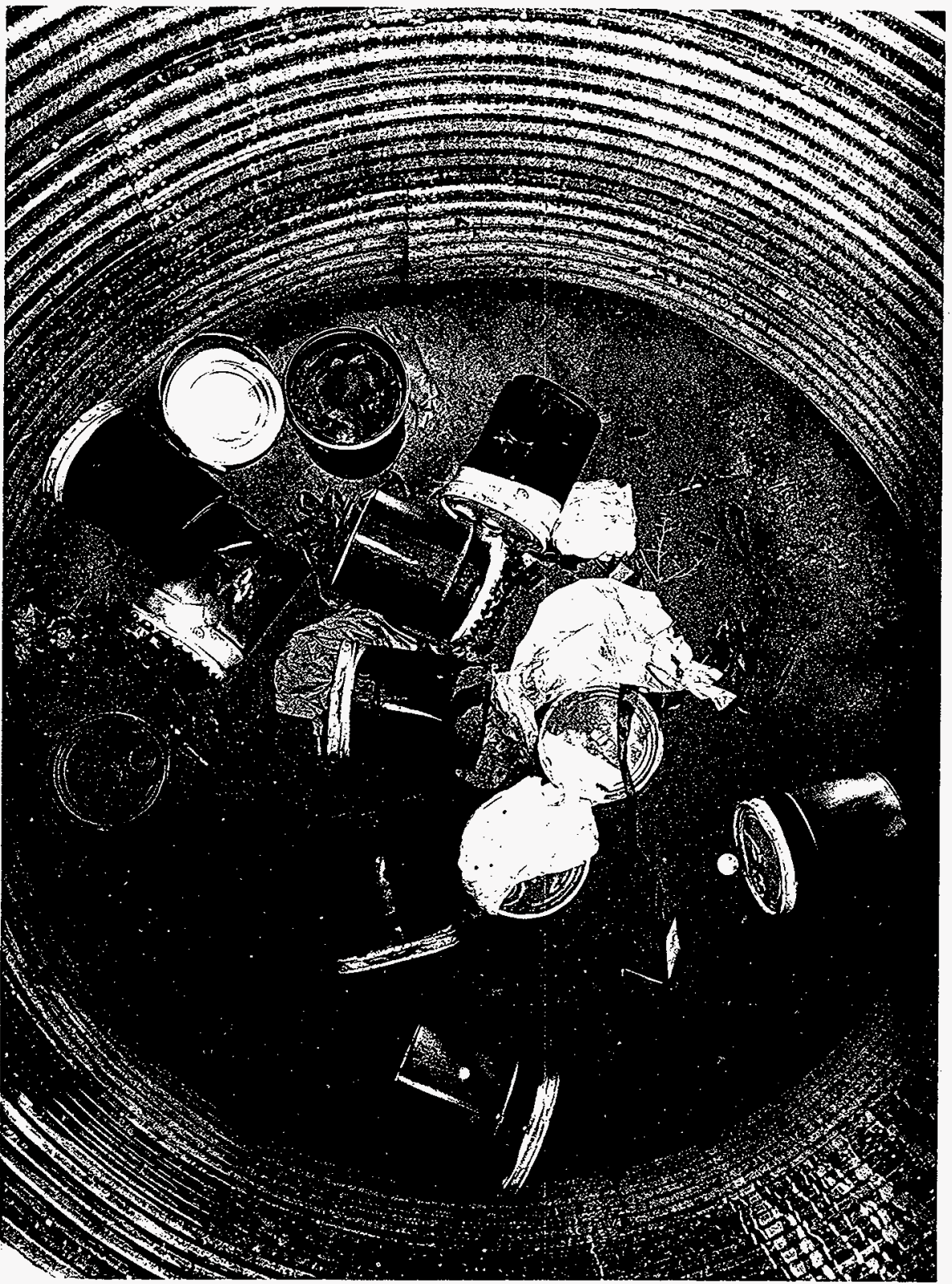


Figure 2-24: Condition of Waste Containers in Caissons (200 Area)

HNF-EP-0649, Rev. 0

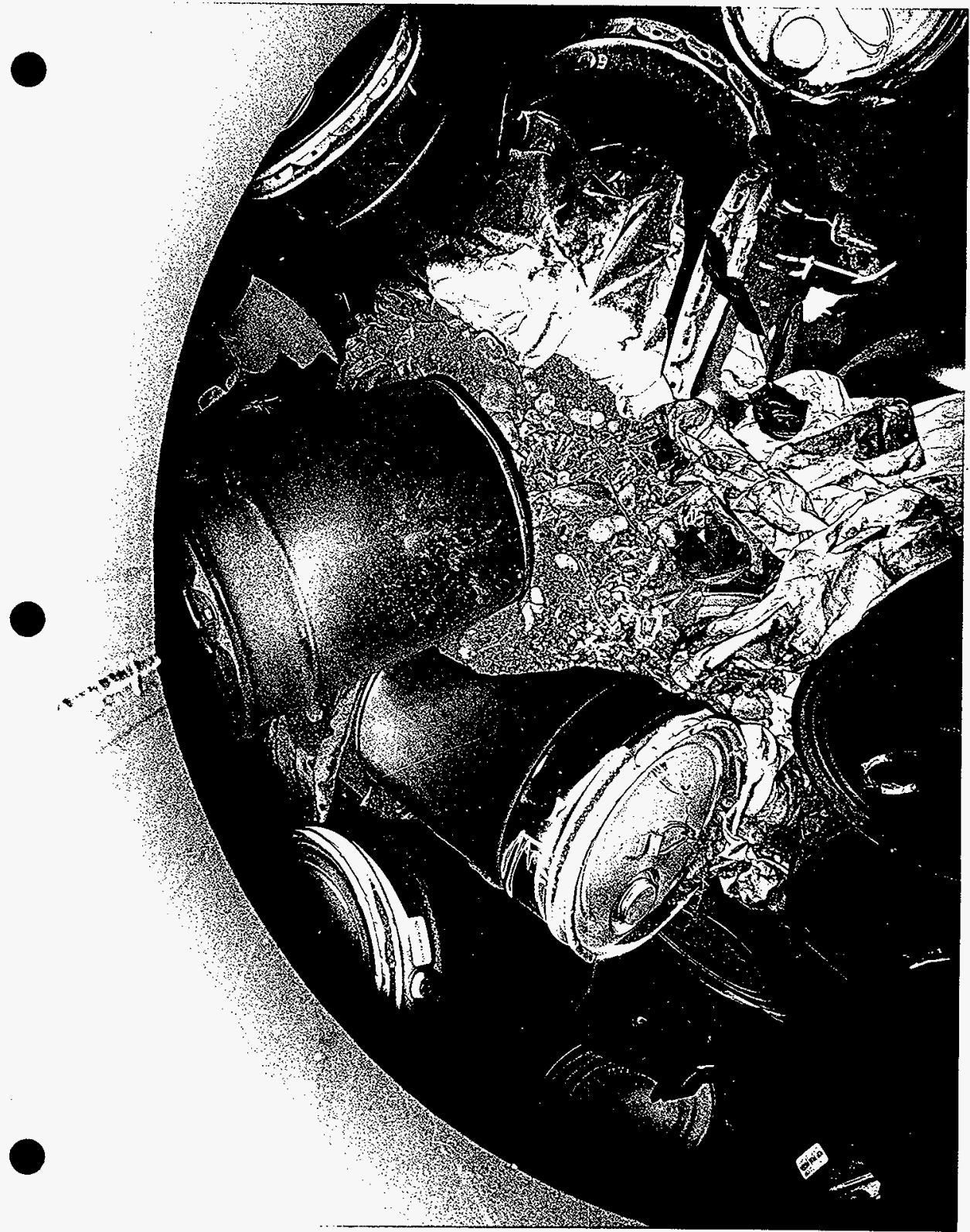


Figure 2-25: Condition of Waste Containers in Caissons (200 Area)

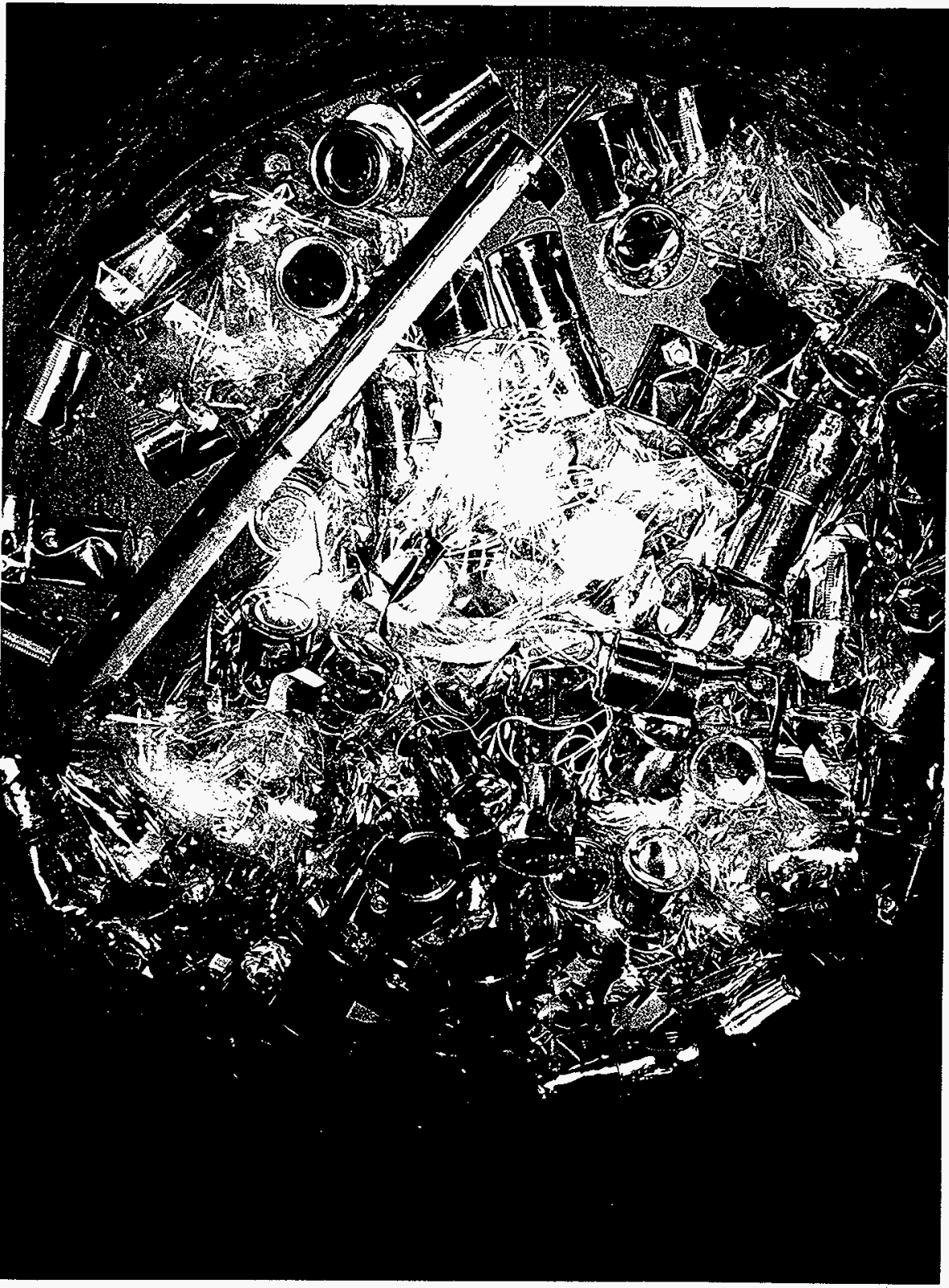


HNF-EP-0649, Rev. 0
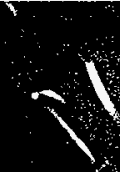

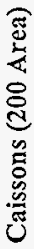

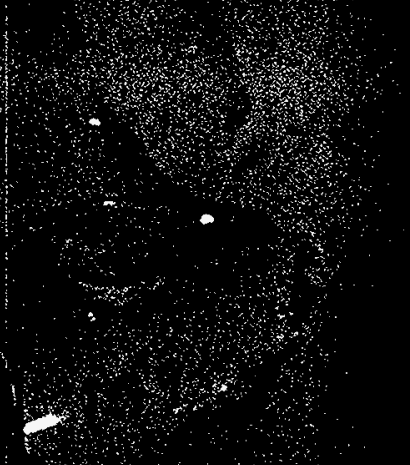

-

if

?

1

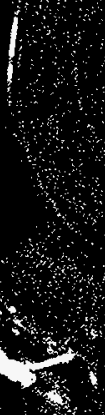




\subsubsection{Disposal Containers}

Low-activity wastes were disposed to the trenches using a variety of containers, including: cardboard cartons, steel drums (barrels), metal buckets, wooden boxes, self-contained equipment items, and plastic wrap. The weight and size of the disposed item typically dictated the type of container used. Appendix $\mathrm{C}$ shows some of the most commonly available standard containers used to dispose of low-level waste during the 1960s. A commonly used container or technique not shown in Appendix $\mathrm{C}$ is plastic wrap. Disposal items too large or cumbersome to fit in more typical containers were wrapped in four to 10 mil plastic sheeting and taped to seal the item from the environment. This method provided limited contamination protection and was only used for low-activity items too difficult to package otherwise. Plastic wrapped items were either loaded directly on a flatbed truck or, if limited to just a few items, were placed in load luggers for subsequent disposal. Load luggers, such as the one shown in Figure 2-27, were primarily used for cartoned waste. For record keeping purposes, they were estimated to hold approximately 100 feet $^{3}$ of waste (Backman 1964). Actual load lugger volumes could be up to 250 feet $^{3}$ if packed tightly and heaped to the top. Load luggers were available in several different sizes and shapes. Luggers used to hold waste cartons were typically equipped with a cover to protect the cartons from adverse weather. 


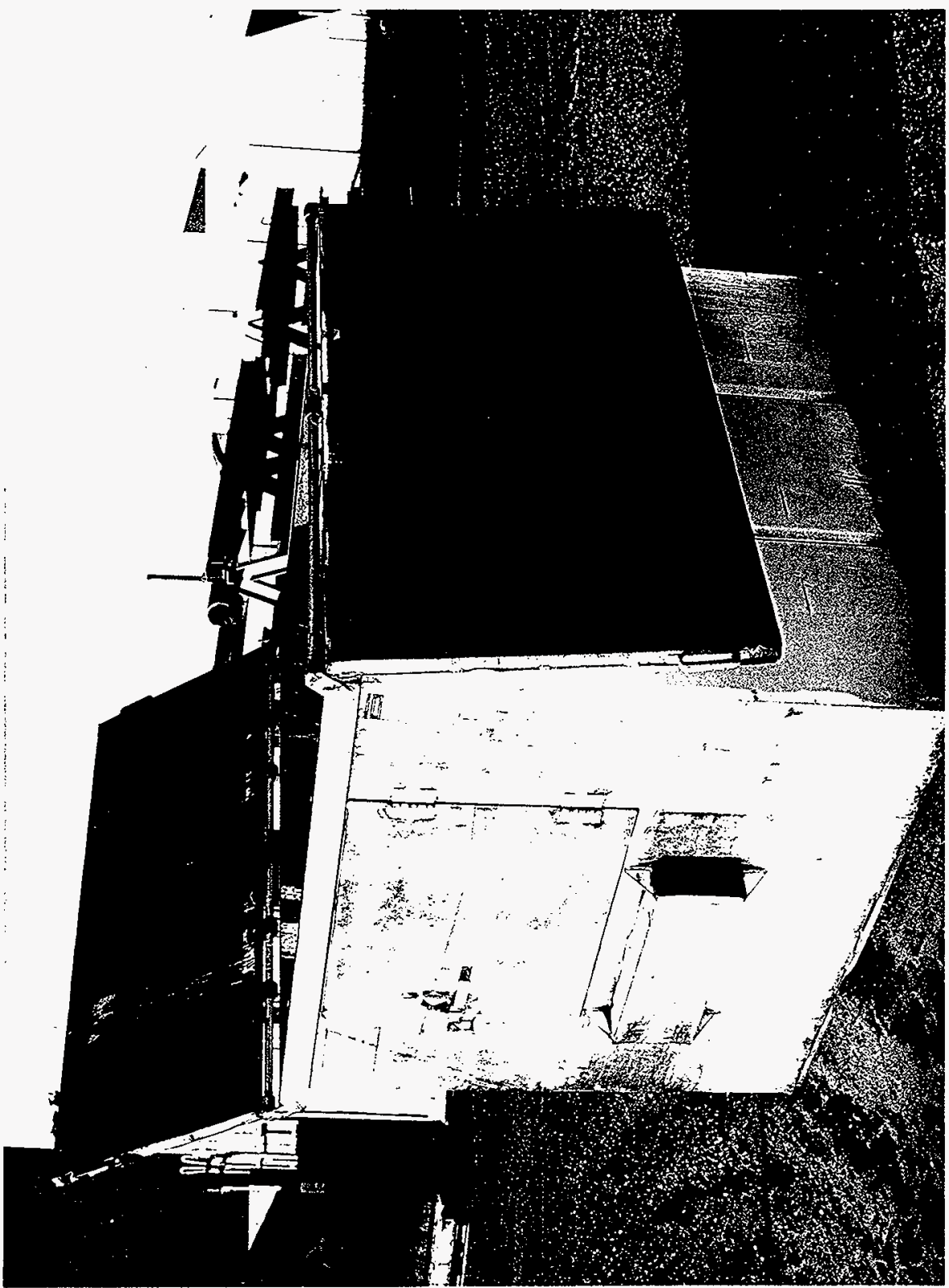


Intermediate and high-activity wastes were generated exclusively in hot cell activities in the 325-A, 325-B, and 327 facilities. Before March 1964, the 325-A hot cell disposed its intermediate and high-activity wastes to the trenches in lead-lined concrete drums (Keene 1961, Appendix B). These drums had an eight-inch diameter culvert centered in the 55-gallon drum, surrounded by concrete on the bottom and sides (Figure 2-28). In addition, the culvert might also be surrounded by one or two inches of lead, depending on shielding requirements. The culvert was typically filled with three $0.15 \mathrm{feet}^{3}$ paint cans that were approximately seven inches high by 7.5 inches in diameter. The culvert was capped with a lead plate; then concrete was poured over the cap and into the remaining void space to fill the drum. The drums were made up and topped with concrete in a simple walk-in hot cell facility located in Room 530 of the 325 building. Nearby gloveboxes and open face hood areas were used as a support area for these wastes. Many radioactive liquids, including plutonium contaminated liquids, were solidified in concrete in this facility. The facility has been decommissioned and the walk-in concrete hot cell removed.

In January and March of 1964, 325-A hot cells began using the one-ton and seven-ton dry waste casks (Figure 2-22) to ship intermediate and high-activity wastes to the 618-11 burial ground. The casks were loaded horizontally with waste containers from the hot cells (Appendix C) and the wastes shipped to the burial ground in a vertical position. The one-ton waste cask transported one-gallon waste cans (three per shipment) to the burial ground, while the seven-ton waste cask transported the 15-gallon black iron cans, the five-gallon paint cans or buckets, and the 15-gallon stainless steel resin cans (Figures 2-29 and 2-30). The 15-gallon black iron cans and the five-gallon paint cans had lids held on by a screw-dog that was forced under the lip or into the can side. The 15-gallon resin cans had lids welded on. The one-gallon cans initially used a press-fit lid, but were later changed to lids held on with metal clips, because some lids came off during discharge, resulting in contamination at the burial ground.

The 15-gallon containers from 325-A hot cells were disposed to the drum storage units; the one and five-gallon cans were disposed to both drum storage units and caissons (Section 3.2). All dry waste disposal casks that transported intermediate or high-activity wastes to the 618-11 caissons or drum storage units were single lever, single dump casks, except for the 327 building gatling gun cask.

The 327 gatling gun cask held 12 one-quart sealed cans. The cask was transported to the hot cell in a horizontal position and mounted to the exterior of the cell at the loadout position. High-activity wastes were loaded into one-quart industrial cans that had lids sealed in the cell using a commercial canner. Two sealed cans were loaded into each barrel of the cask. The turret was rotated, via the ex-cell cask handle, and each barrel was loaded. After loading, the cask was detached from the cell exterior wall, removed to the cask load-out area, and loaded onto the flatbed truck for transport to the burial ground. 
Figure 2-28:

\section{5-A Hot Cells High Activity Waste Disposal Method 1960 to 1964}

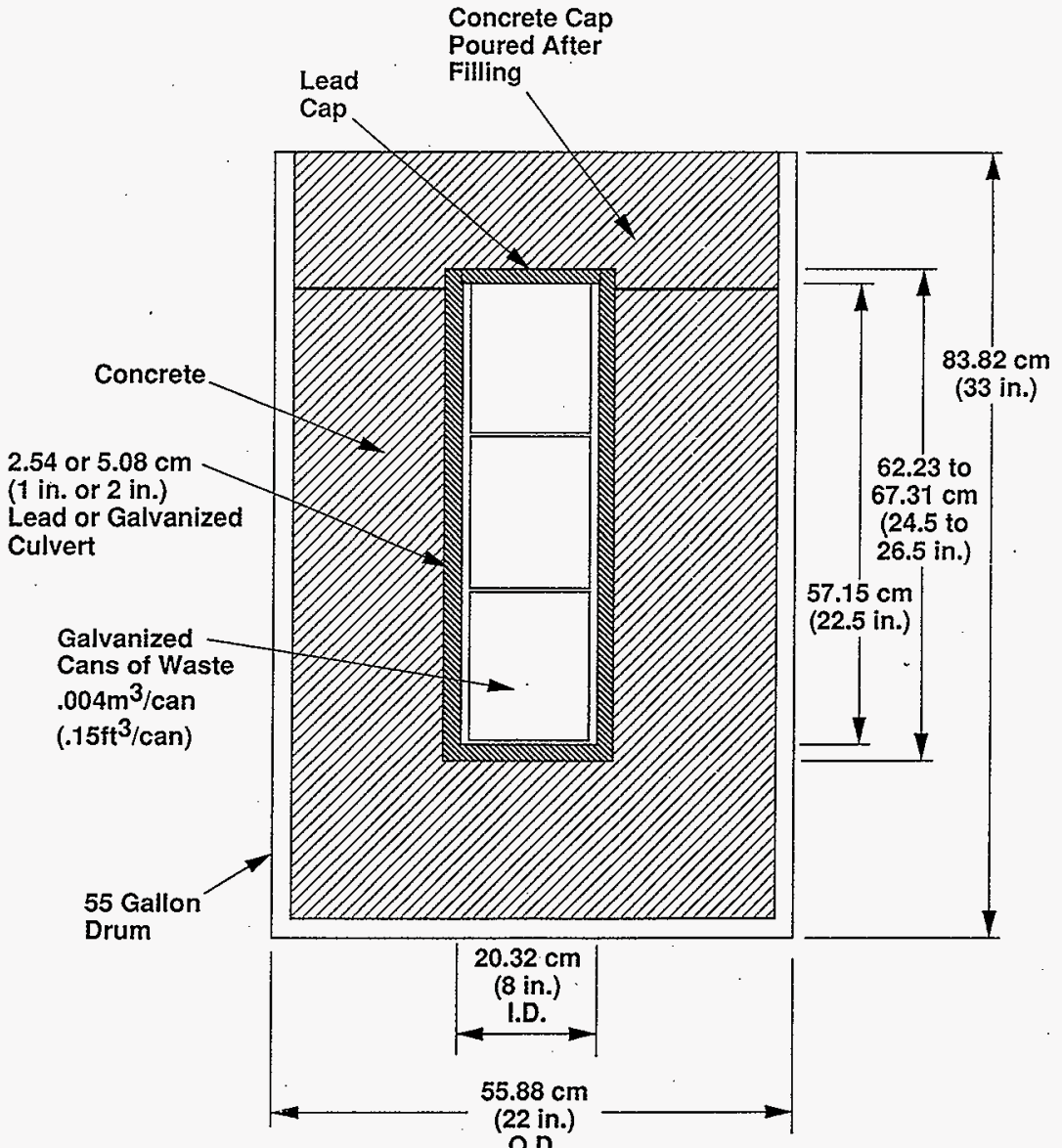

39303020.1 
HNF-EP-0649, Rev. 0

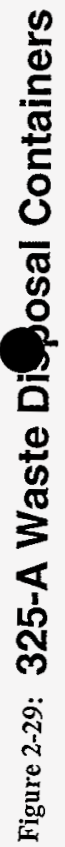

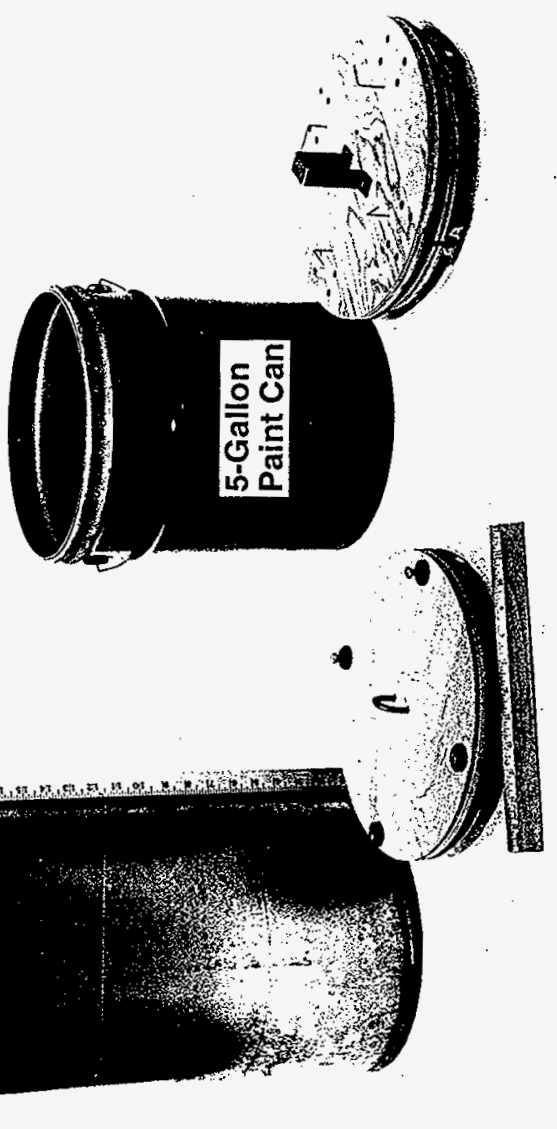


HNF-EP-0649, Rev. 0

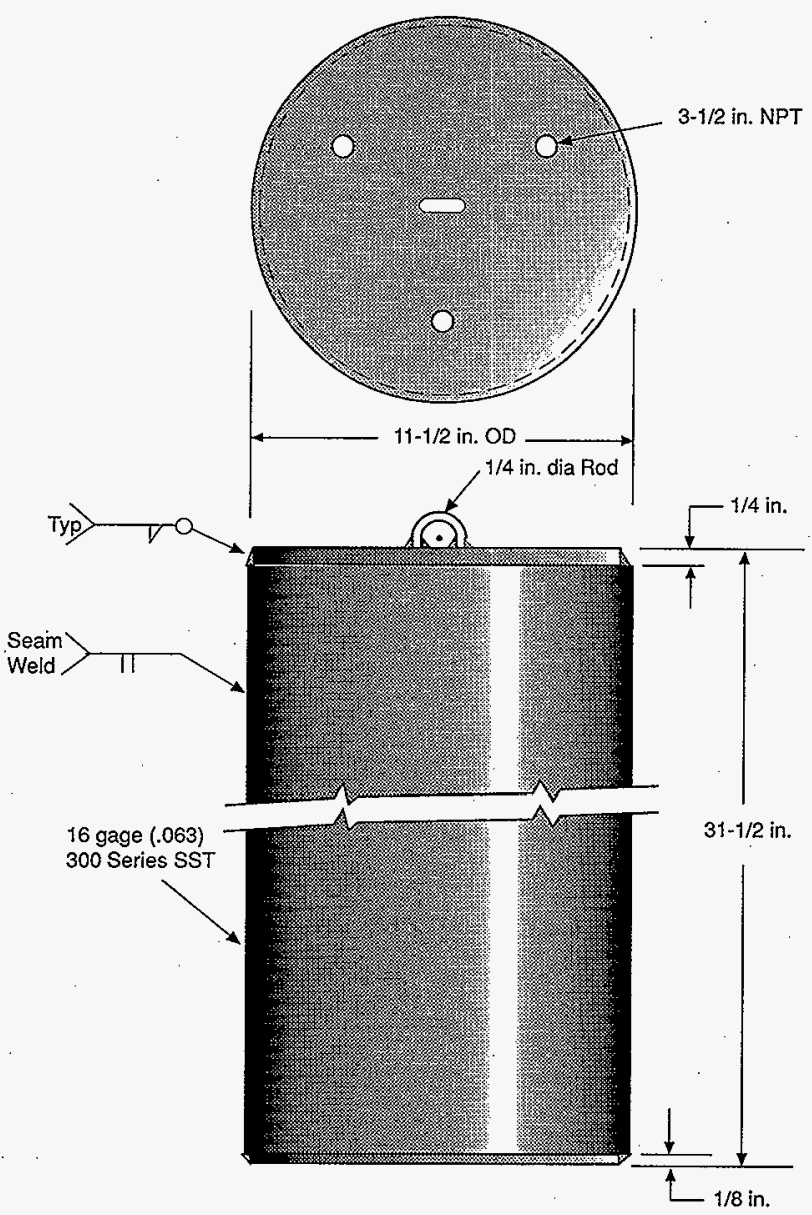

39303044.4

Figure 2-30: Resin Disposal Canister 
The cask was transported in a vertical position to the 618-11 burial ground. The gatling gun cask was centered over a caisson or drum storage unit and the cans discharged, barrel by barrel, through the discharge port on the bottom (Figure 2-31). The cans were discharged as the turret was turned by an operator on the truck bed (Figures 2-32 and 2-33). The discharge operation appeared very much as Figure 2-22 depicts the 325-A hot cell waste disposal.

The gatling gun cask was used only to dispose of high-activity waste. The waste was first disposed to the drum storage units and later to the caissons. The records show that 80 gatling gun cans were disposed to the 618-11 burial ground between July 1, 1963 and December 31, 1963. Another 150 cans were disposed to the burial ground between January 1, 1964, and June 30, 1964.

Only one gatling gun cask was built. It was first used on May 25, 1959 (Gift HW-76192). A technical data sheet on the cask is included in Appendix C. The gatling gun cask was first used at 618-10 burial ground. After 618-10 was closed on September 16, 1963 , the cask was used exclusively for high-activity disposals at the 618-11 burial ground. Records indicate the gatling gun disposal at the 618-11 burial ground ended before June 30 , 1966.

The use of milk pail casks was the other method used to dispose of 327 building hot cell wastes to the 618-11 burial ground (Figures 2-34 and 2-35). An information sheet on the milk pail cask is provided in Appendix C. Milk pail containers were six liter aluminum cans that were loaded with dry waste in the cell. The pails were seven inches in diameter, 10 inches high, with a bail-type lifting handle riveted to the pail. The milk pails were made of extruded or spun aluminum approximately 0.025 inches thick. They were inserted into a plastic bag, that was held in place by a rubber band, before being placed into the cell to provide relative contamination protection to the outside of the pails. The seven inch diameter container allowed the waste cans to be inserted through a standard cell roof, and be large enough to accept about 20 grinding and polishing dises stacked horizontally (McCormack 1962). The cans were pulled up into the milk pail cask from the inside of the hot cell, using the wire bail handle.

After filling with waste, the milk pail was sealed before removal from the cell into the cask. The seal was made by adding a $20 \mathrm{wt} \%$ gelatin in water solution to the milk pail. The gelatin and water were mixed together and the gelatin completely dissolved outside the hot cell. Hot water had to be used to dissolve the gelatin. While still warm, the gelatin was transferred into the cell through a liquid transfer line. The gelatin was placed over the waste and allowed to cool and set up for 16 hours before the milk pail could be removed from the cell. The gelatin set could be checked either mechanically with the manipulators or visually. 


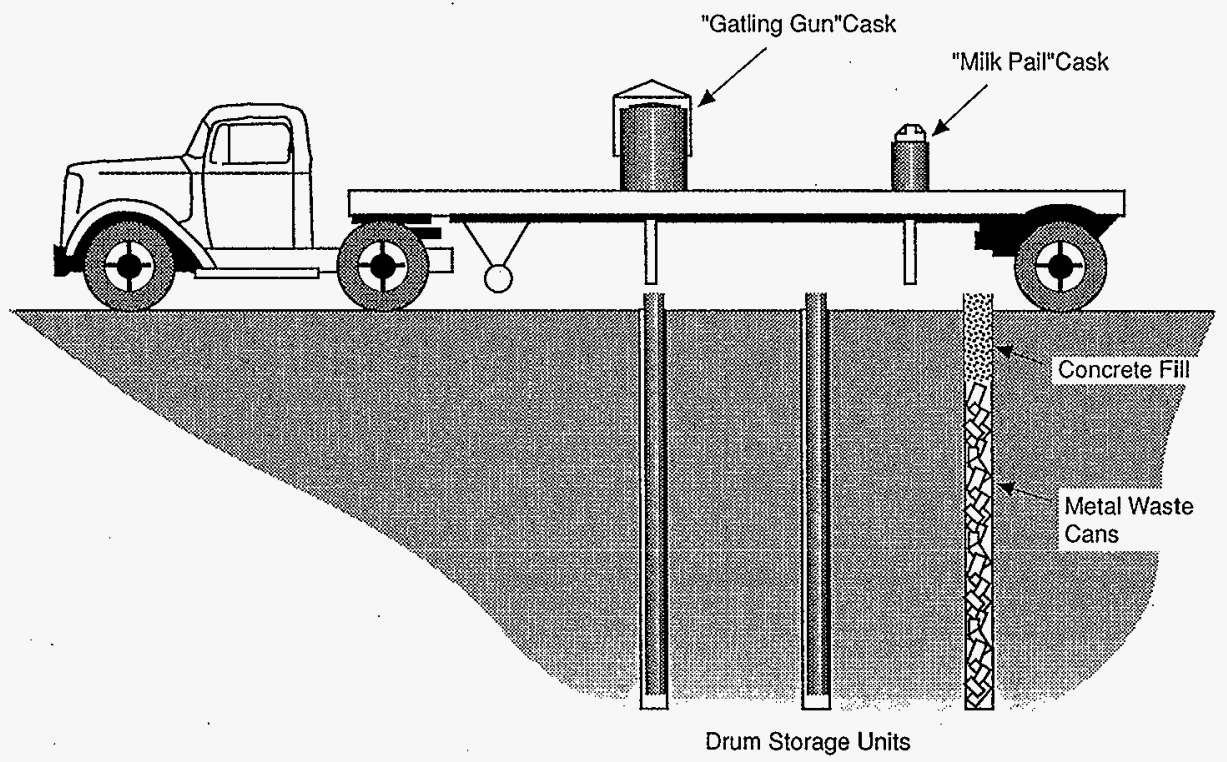

39303044.6

Figure 2-31: Radioactive Dry Waste Disposal 
Figure 2-32: 5-Ton Gatling Gun Cask Isometric

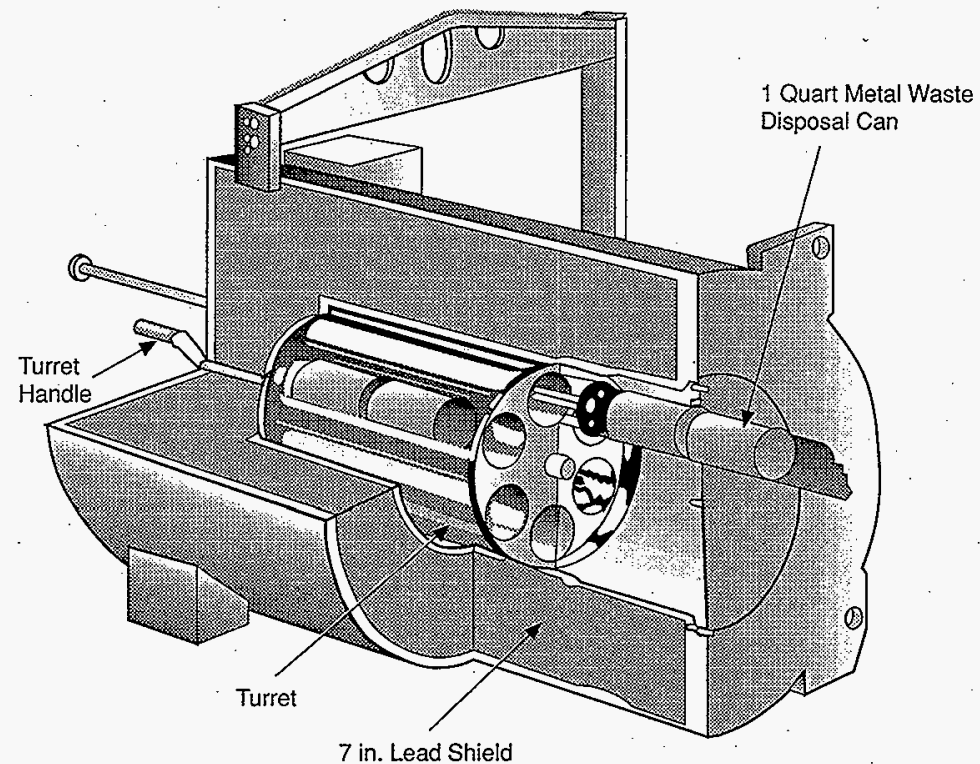

39303044.1

\section{Ton "Gattling Gun" Cask (Held $12-1$ Quart Cans)}


HNF-EP-0649, Rev. 0

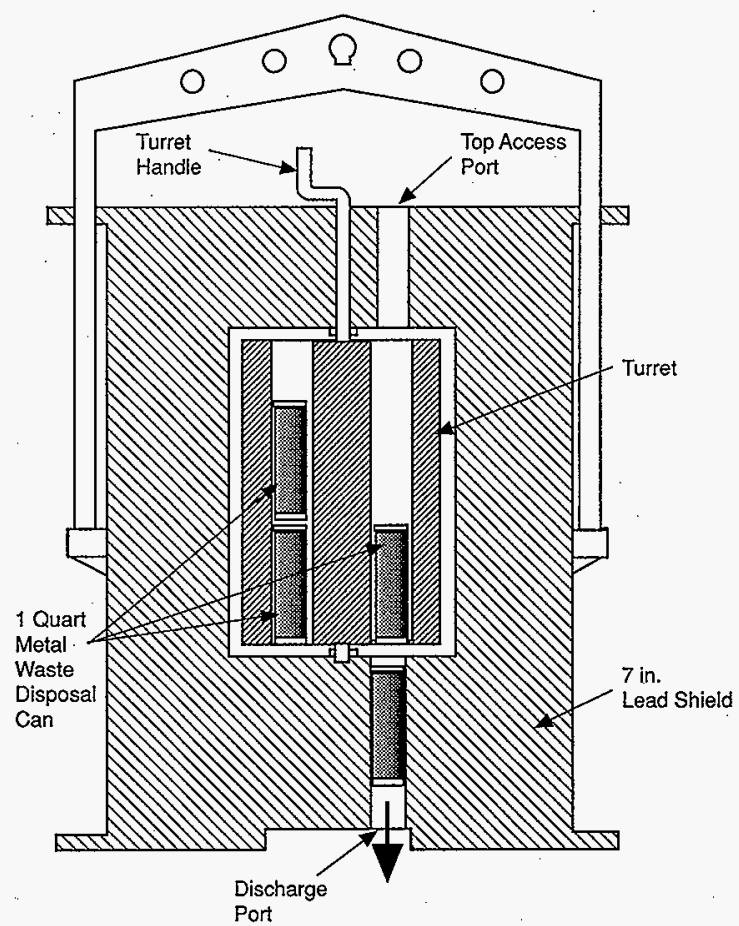

39303044.5

Figure 2-33: 5 Ton "Gatling Gun" Cask (Held 12 - 1 Quart Cans) 
HNF-EP-0649, Rev. 0

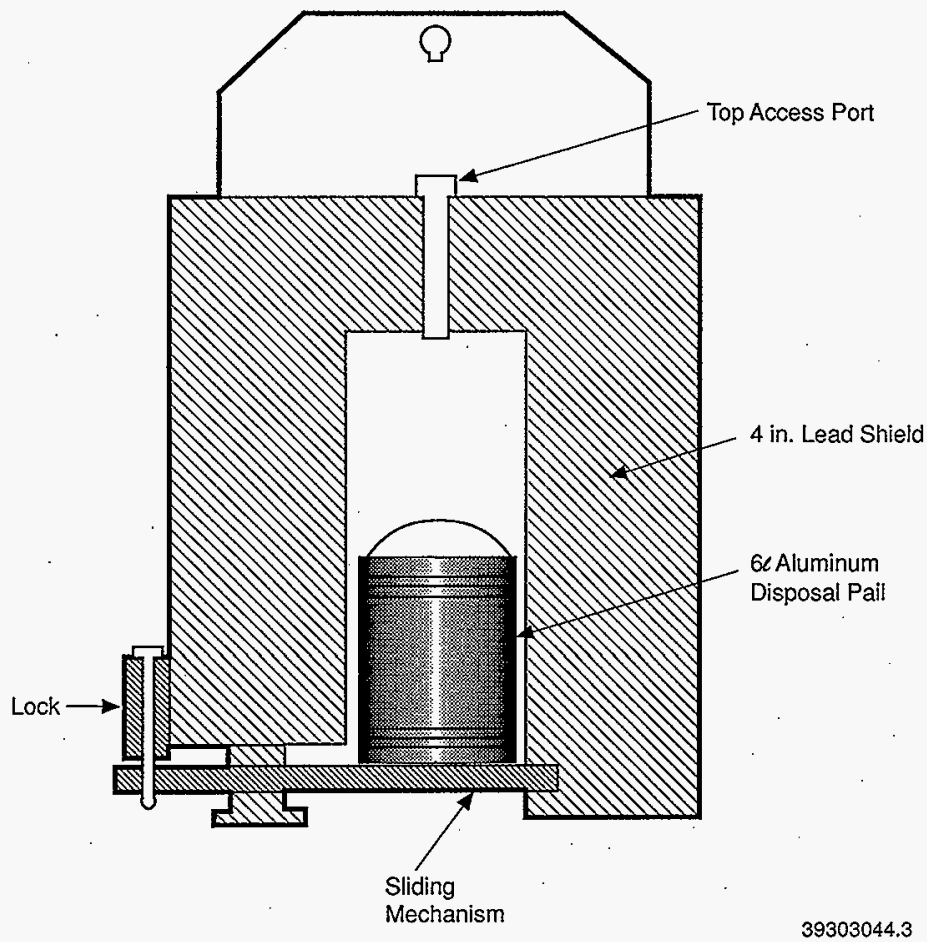

Figure 2-34: $3 / 4$ Ton "Milk Pail" Cask 
HNF-EP-0649, Rev. 0

Figure 2-35: 3/4-Ton Milk Pail Cask Isometric

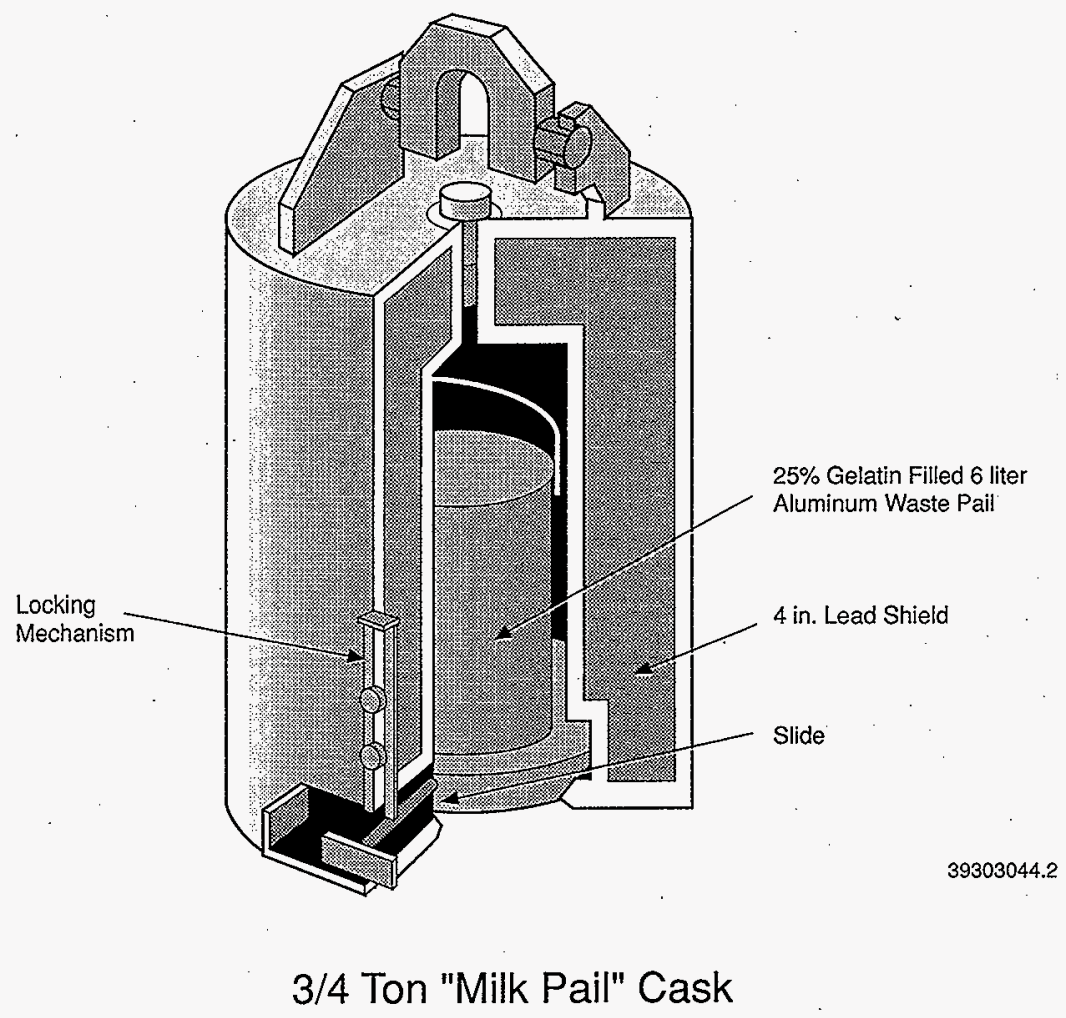


When set, the gelatin solution was strong enough to hold a 10-pound lead brick rigidly in place. The gelatin also would effectively trap small particles and dust. No other lid or seal was considered to be required for disposal of the milk pail waste (Gift HW-76192). The $20 \mathrm{wt} \%$ gelatin was less expensive and was considered to be more efficient for sealing milk pails than a mechanical lid. It was also considered more satisfactory to work with in-cell than other encapsulating or sealing materials such as concrete or plaster of paris. However, the gelatin may have been jarred from the milk pails when the waste was dropped into the storage drums or caisson chutes. The gelatin may have also deteriorated over the years of storage. Gelatin is also degradable through biological action and other means, while concrete, grout, or plaster of paris are much more resistant. However, at that time, disposal was considered complete once the waste was disposed to the trench, drum storage unit, or caisson.

The milk pails had a 30 pound weight limit, including gelatin. That meant the each milk pail was limited to 17 pounds of waste, because the gelatin seal weighed 13 pounds. The maximum density of waste was restricted to $<10.7$ pounds/gallon. Once the gelatin was set and the 16 hour waiting period ended, the milk pail was removed into the cask through the roof of the hot cell by a wire hooked to the pail handle.

The milk pail cask was suspended over the hot cell on the crane with the bottom slide mechanism open and the cell top access port removed. A wire was run through the top access port of the cask into the cell where it hooked onto the handle of the milk pail. The pail was pulled up into the milk pail cask, and the bottom slide of the cask was closed and locked. A milk pail operating procedure written in the late 1950's is included in Appendix D.

The milk pail cask was loaded vertically onto a flat-bed truck specially designed for the cask and transported to the burial ground. At the 618-11 burial ground, the truck was positioned over the active drum storage unit or caisson. The milk pail was discharged by removing the cask locking pin and pulling the discharge lever. After discharge, the cask lever was pushed back and the lock secured. The area and cask were surveyed, any contamination cleaned up, and the unit was returned to the 300 Area. 
Two milk pail casks were constructed for the 327 building. They were, completed June 18, 1959, and July 20, 1961 (Gift, HW-76192). Records indicate that from January 1, 1962, until June 30,1962, 198 milk pails were disposed of in the 618-10 burial ground, since no drum storage units existed at the 618-11 burial ground during this period (Berreth 1963). After the 618-11 burial ground was modified in August 1963 to provide drum storage units, the majority of the 151 milk pails disposed to burial grounds between July 1, 1963 and December 31, 1963 went to the 618-11 drum storage units. All milk pails disposed to burial grounds from September 30, 1963 to December 31, 1967 went to the 618-11 burial ground drum storage units or caissons.

Operations at the 618-11 facility were closed after new caissons were constructed in the 200 West Area. All waste from the 300 Area after December 31, 1967 was shipped to the 200 West Area for disposal in either the waste trenches or the newly constructed caissons.

After 1965 , milk pail waste generation in the 327 facility was listed, in part, by 327 building radiation surveys, and also in building operational logs. The survey summaries are given in Appendix G. The radiation surveys and the milk pail operations listed in building logs will be discussed in Section 3.5.

Another disposal cask was used in the 325-B analytical hot cells. The cask held two one-gallon cans, and was sealed by a friction fit lid. The cask was loaded by backing it horizontally against the cell wall, sliding open the door, and pushing the cask chute into the cell for loading. The chute with the two cans was then withdrawn into the cask and the door slid shut.

A similar chute disposal system was used to dispose of the one gallon waste cans shown in Figure 2-25. However, the chute fell from the cask and lies at the bottom of the caisson with the waste. This particular chute would hold about 7 one-gallon paint cans.

The cask was then hauled to a drum storage unit or caisson in a modified pickup truck. The truck was designed to tip the cask up over the back of the bed in line with the drum storage unit or caisson as shown in Figure 2-36. The cask lid was opened and the cans dropped into the disposal unit. The truck became contaminated and is thought to have been buried at the 618-11 burial ground when it couldn't be sufficiently decontaminated.

\subsection{WASTE SITE DATA DISCREPANCIES}

Much of the characterization information previously written on the 618-11 burial ground does nothing more than discuss physical characteristics of the Hanford Site geology, climatology, hydrology, etc. Much of the information reviewed for this document was incorrect. Several documents contained or reprinted incorrect or unfounded information. Few documents written contain 618-11 burial ground and waste characterization information. The many personal interviews conducted during the course of this document research did little to help in resolving 


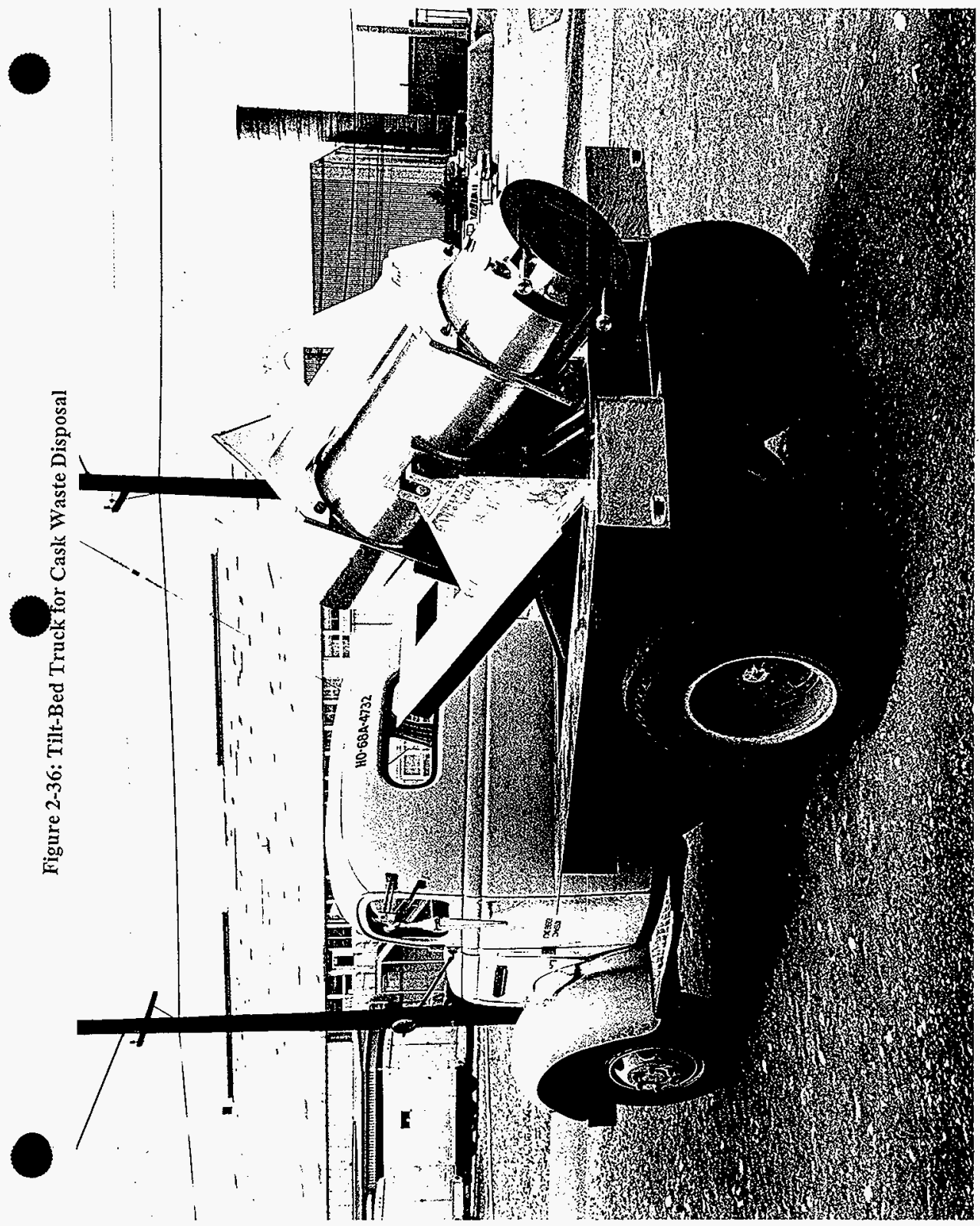


these inconsistent issues. It should also be noted that many characterization documents, generated during the burial ground operation, were destroyed just a few years ago. However, several data pieces were found that provide characterization data. These data were made into record form, and can be found in Appendices A, E, F, G, and $\mathrm{H}$ of this document.

As an aid in evaluating inconsistences discovered during research for this document of existing 618-11 burial ground information, this Section, in conjunction with Sections 2.2 .1 to 2.2.4, have been written. New information and documentation have been discovered and are presented for the first time in this document.

Several discrepancies exist in the data of the 618-11 burial site. These discrepancies show up in the documentation written during the past three decades to describe and characterize the site. Foremost, are the inaccuracies in the number of caissons and drum storage units at the site. Documents differ on the total number of drum storage units and caissons. The range varies from 12 trenches and 54 caissons (Pauly 1990) to three trenches, one large buried culvert, and three large underground tanks (Phillips 1977). This document reports three trenches, 50 drum storage units, and five eight-foot diameter caissons.

The most reliable reference for the number of drum storage units and caissons should be from the 300 Area Support Services Operations (Caldwell 1971). The letter indicates 53 drum storage units, one three-foot diameter culvert and three eight-foot diameter underground tanks (caissons) for dry storage. The recent EMI completed in 1995 (Figure 2-15), and the August 1964 aerial photograph of the site refute this count. It is clear there are 50 drum storage units. The caisson count is either five eight-foot diameter caissons or three eight-foot diameter caissons and one 12-foot long by eight foot diameter double chute caisson (Figure 2-11). To have installed a three foot diameter culvert during June to August 1964 is inconceivable, after so many contamination spread problems with drum storage units (Appendix $\mathrm{H}$ ), contamination concerns by the AEC (Backman 1963a), and new caisson designs being evaluated (Graybeal 1964 and GE, 1962-1964).

In addition, the installation of a three foot culvert seems unlikely based on the Graybeal 1964 caisson drawings, which cites that two dry waste disposal tanks were installed (GE 1962-1964), and the survey spacing measurements (Figure 2-11). If the two Graybeal caisson designs were installed, the entire area between W2,939.17 and W2,906.67 would have been taken up, leaving no room for a culvert.

Several discrepancies exist in the site engineering drawing. The first burial ground layouts shown in H-3-9951 were done for 14 trenches, running east/west, to be contained in a plot 1,000 feet east/west by 1,500 feet north/south. That plot layout was never changed, and is still shown incorrectly on the current H-6-930, Revision 0, drawing issued April 3, 1979.

The drawing also shows a scale of one inch $=100$ feet in the sign-off block, but labels the base plot layout at one foot $=100$ inches and the "north portion enlarged" as 
one foot $=50$ inches. The north portion enlarged area shows 20 drum storage units in the northern row $(\mathrm{N} 12,458.24)$ while the base scale view shows 21 units. The count of caissons and drum storage units in the other two rows is identical. Westerly grid coordinates are incorrect for the caisson and vent lid, located between W3,000 and W2,993.67. The caisson centerline shown at W 2997.17 and the neighboring caisson vent centerline shown at W2,993.67 should be revised.

The EMI of the site done in 1982 depicts three scattered drum storage unit images in the north row, one missing drum storage unit in the center row, and denotes another caisson at the western end of the center row (Phillips 1982). These discrepancies can be voided by enlargements of site photographs (Figures 2-7 and 2-14) and the EMI/GPR done in 1994 (Bergstrom 1997). The photographic enlargements clearly show three rows of drum storage units. A northern-most row shows 20 drum storage units and the southern-most row shows 10 units. The middle row is split into two segments, with an easterly segment of 10 drum storage units and a westerly segment of 10 units. All drum storage units are evenly spaced so as to match the Hanford drawing H-6-930. Three additional units at W2,939.17 to W2,906.67 appear as the "vent lid" waste burial facility storage units depicted in Detail "B" of drawing H-3-930. Figure 2-14 even shows the larger-diameter unit, shown as 36 inches O.D. at W2,906.67 on H-6-930. These photos, however, do not show the other caissons located between W3,008.67 and W2,982.17. The EMI done in 1995 clearly shows that only two caissons exist at the west, along N12,428.24 (Figure 2-15). 
HNF-EP-0649, Rev. 0

\subsection{WASTES AND WASTE GENERATORS}

\subsection{HISTORY OF 300 AREA WASTE GENERATORS DISPOSING OF WASTE TO 618-11}

When the 618-11 burial ground was opened in 1962, The General Electric Company (GE) was prime contractor for the Atomic Energy Commission (AEC) responsible for operating the Hanford Site. The burial site was constructed to dispose of 300 Area wastes. A map of the 300 Area facilities is shown in Figure 3-1. The major radioactive waste generating facilities during the 1960 s are shaded. Figure $3-2$ is a 1960 s aerial view of the southem portion of the 300 Area showing the 309 building (PRTR), 308, 325, 324, 309 and other 300 Area facilities.

Several 300 area facilities supported reactor design and fuel development, and in so doing became radioactive waste generators. The PRTR frrst reached criticality in October, 1960. The PRTR facilities are shown in Figures 3-3 and 3-4. Test fuels were prepared and fuels were examined in the 308 building (Figure 3-5). Chemical Research and Development (R\&D) for the PRTR activities, as well as other fuel fabrication and reprocessing studies, were conducted in the 325 building (Figure 3-6). Low-activity metallography work supporting the PRTR fuel was performed in the 326 building, along with general laboratory work and testing. Buildings 306 and 313 were used for fuel work, which occasionally generated uranium or other fuel-type waste. The 327 building activities were directed primarily at radioactive metallurgy, and post-fuel irradiation studies supporting those conducted in the 325 and 326 buildings. The 329 building was used for low-level counting work. In addition to counting radioactive materials, checking for residual radioactivity on apparently non-radioactive materials such as fruits and vegetables was also conducted. Most waste from the 329 building was designated non-radioactive. Plutonium-uranium extraction (PUREX) reprocessing studies took place in the 321 building, with support from laboratories in the 3706 building and other locations. Radioactive laboratories were still operating in the 3706 building until the mid-1960s. Operations for the 340 building included decontamination and waste handling activities in support of the other 300 area facilities.

Most reactor type work in the 1960s was conducted in PRTR studies or was preparatory work for fast-flux and high-temperature reactors like the Fast Flux Test Facility (FFTF) Reactor. The 308 building was used primarily for PRTR work and later changed to accommodate FFTF work. The 308 facility undoubtedly had the largest plutonium inventory of any 300 Area facility during this time period. The $308,309,325,327$, and 326 buildings were the largest solid-waste generators in the 300 Area. Initially, however, only the 325 and 327 facilities generated medium and high-activity wastes. The PRTR reactor operations also generated some medium and highactivity wastes. Later, remote handled wastes were generated from the 324 hot cells.

General Electric Company transportation organization handled the carton radioactive waste. Load luggers similar to the one shown in Figure 2-27 were placed outside each waste 


\section{Area}

Figure 3-1: 300 Area

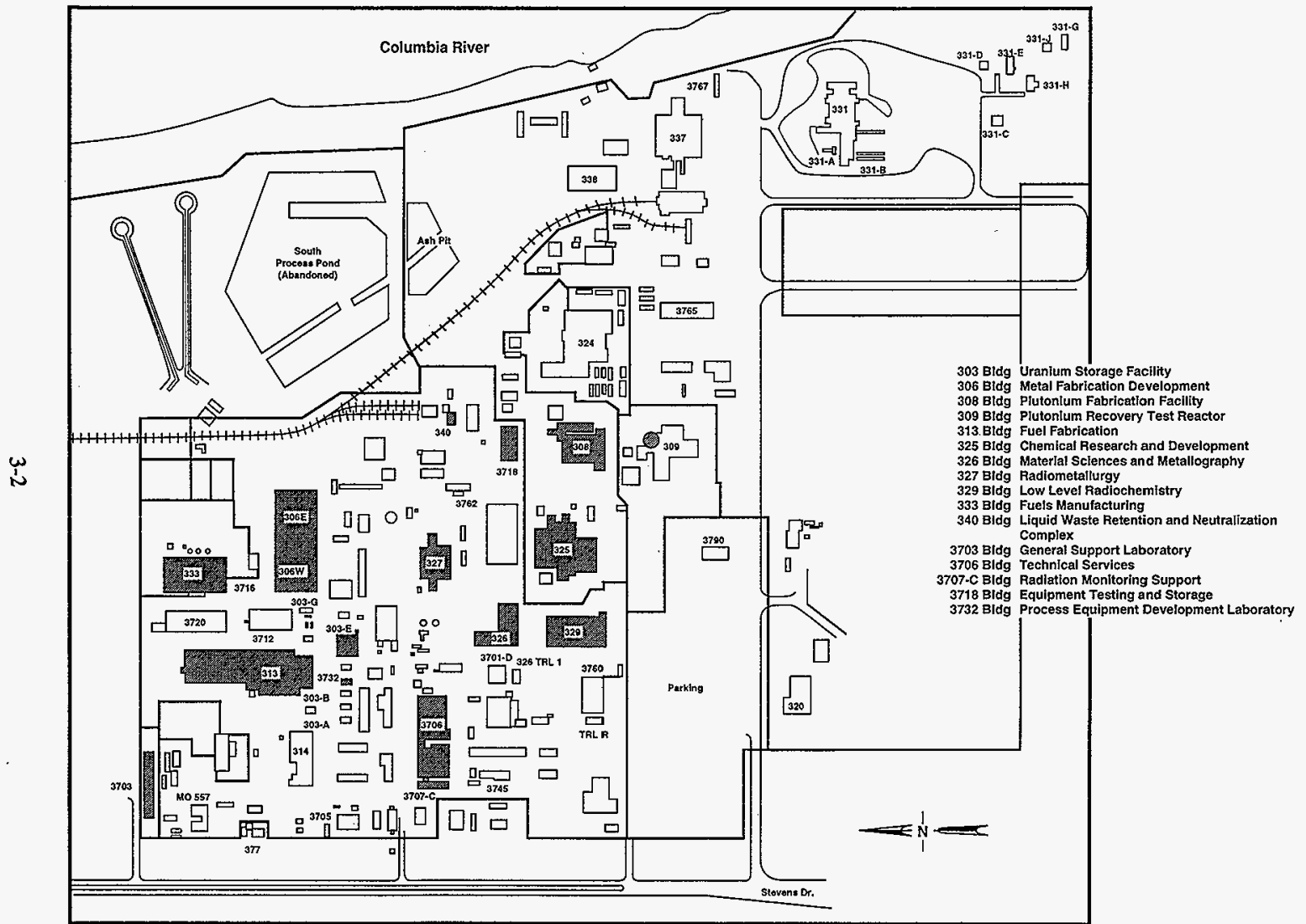




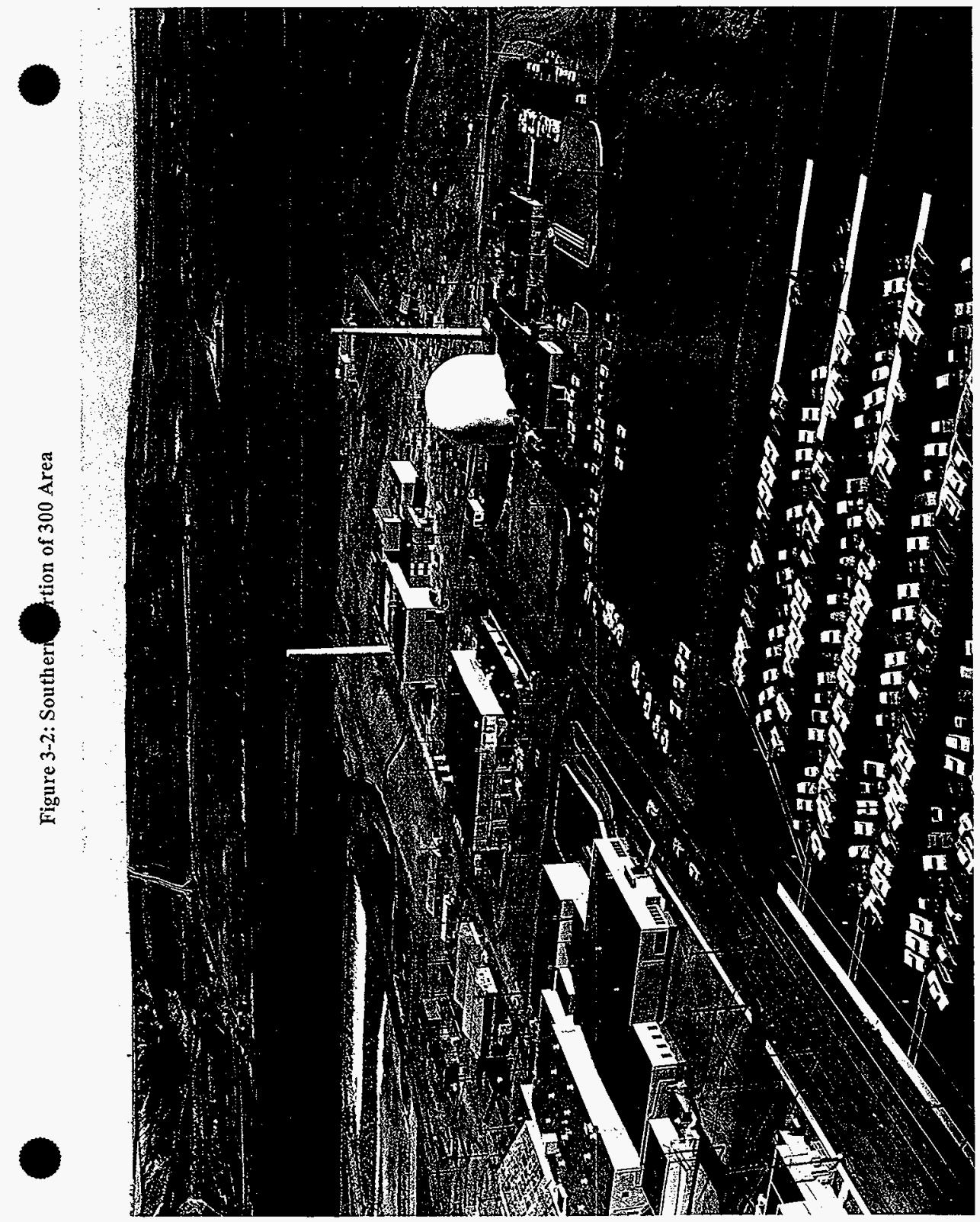




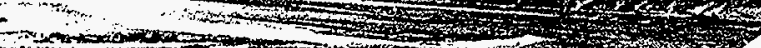
posing Q

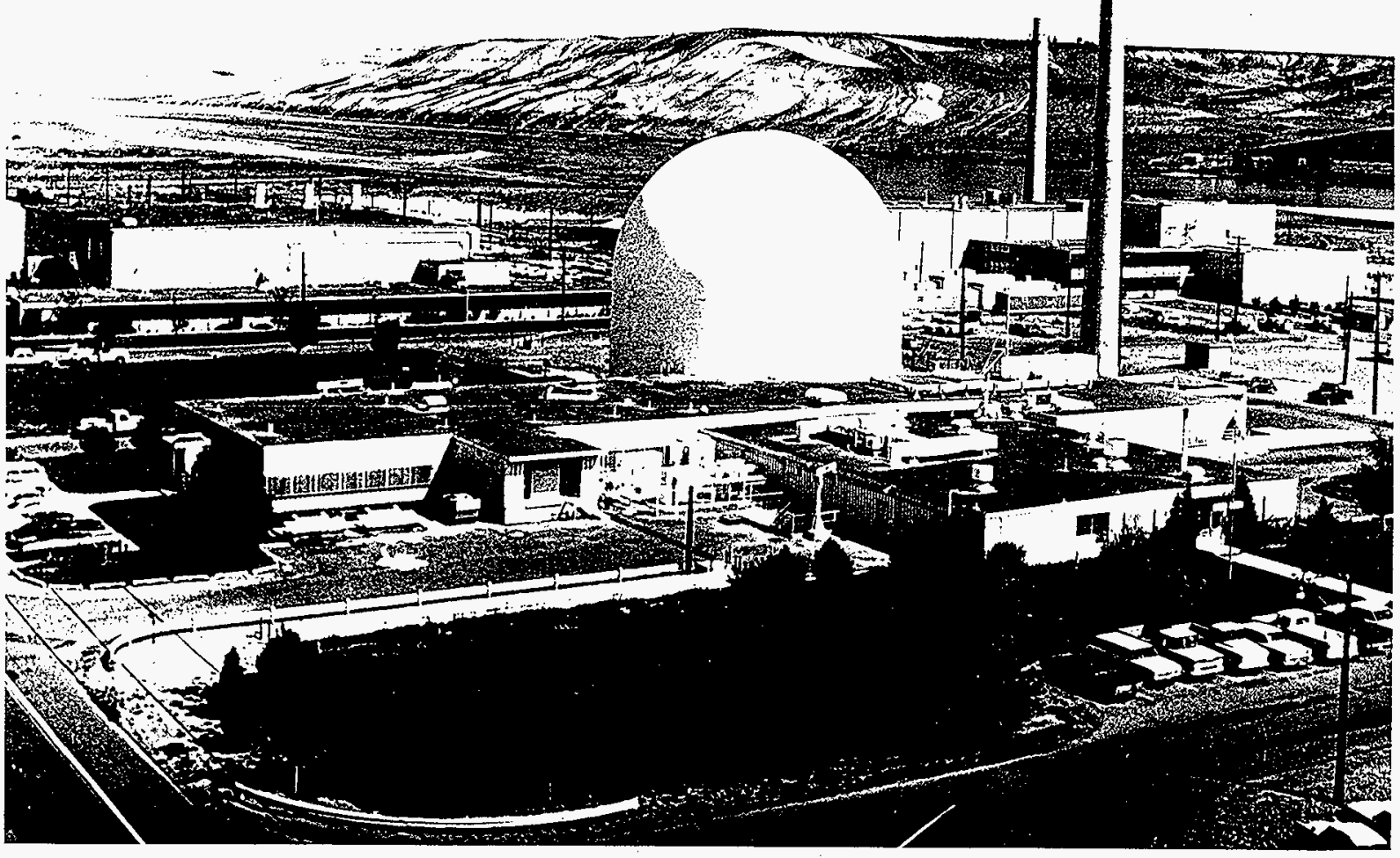




\section{Plutonium Recycle Test Reactor and Building}

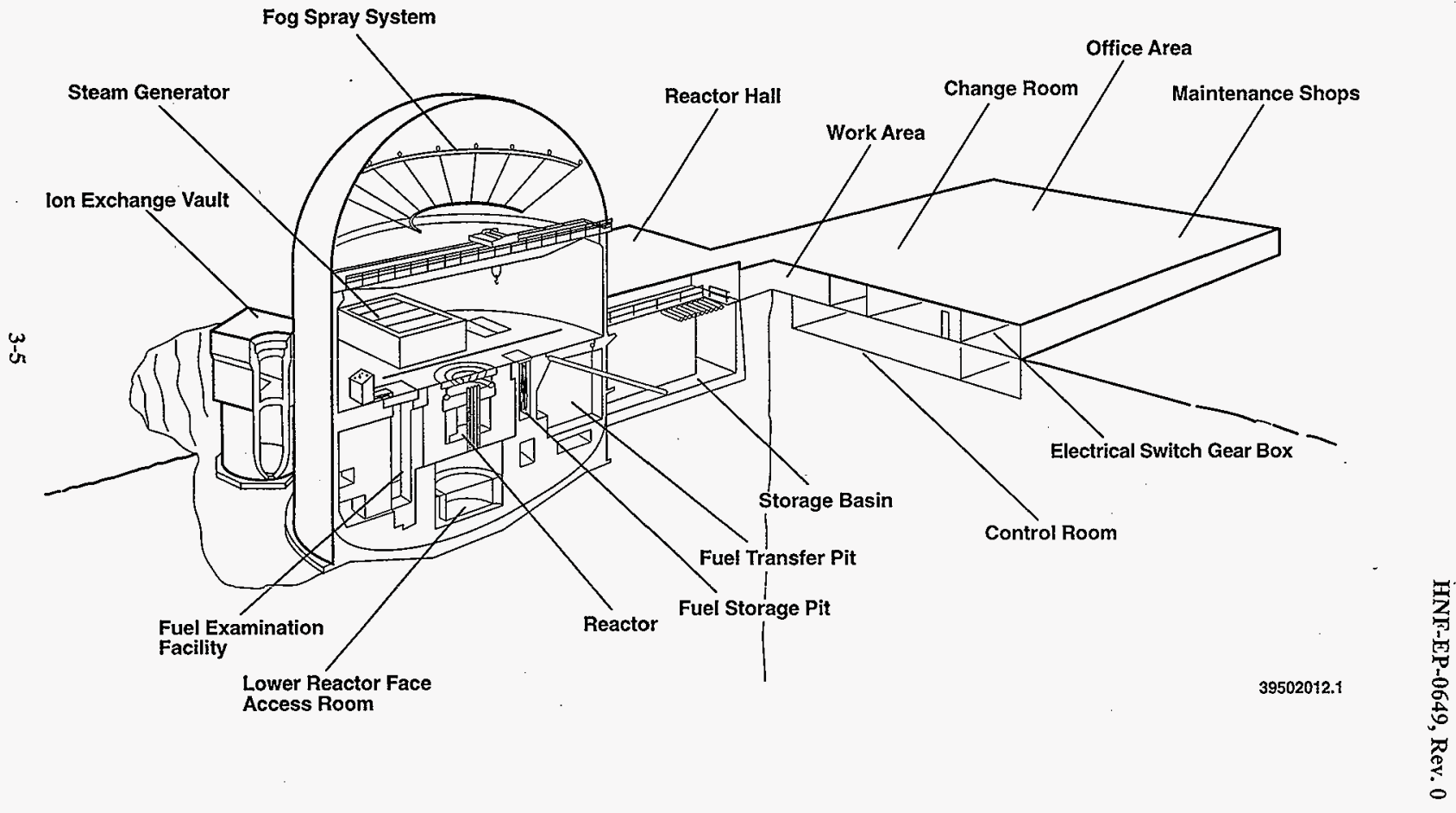



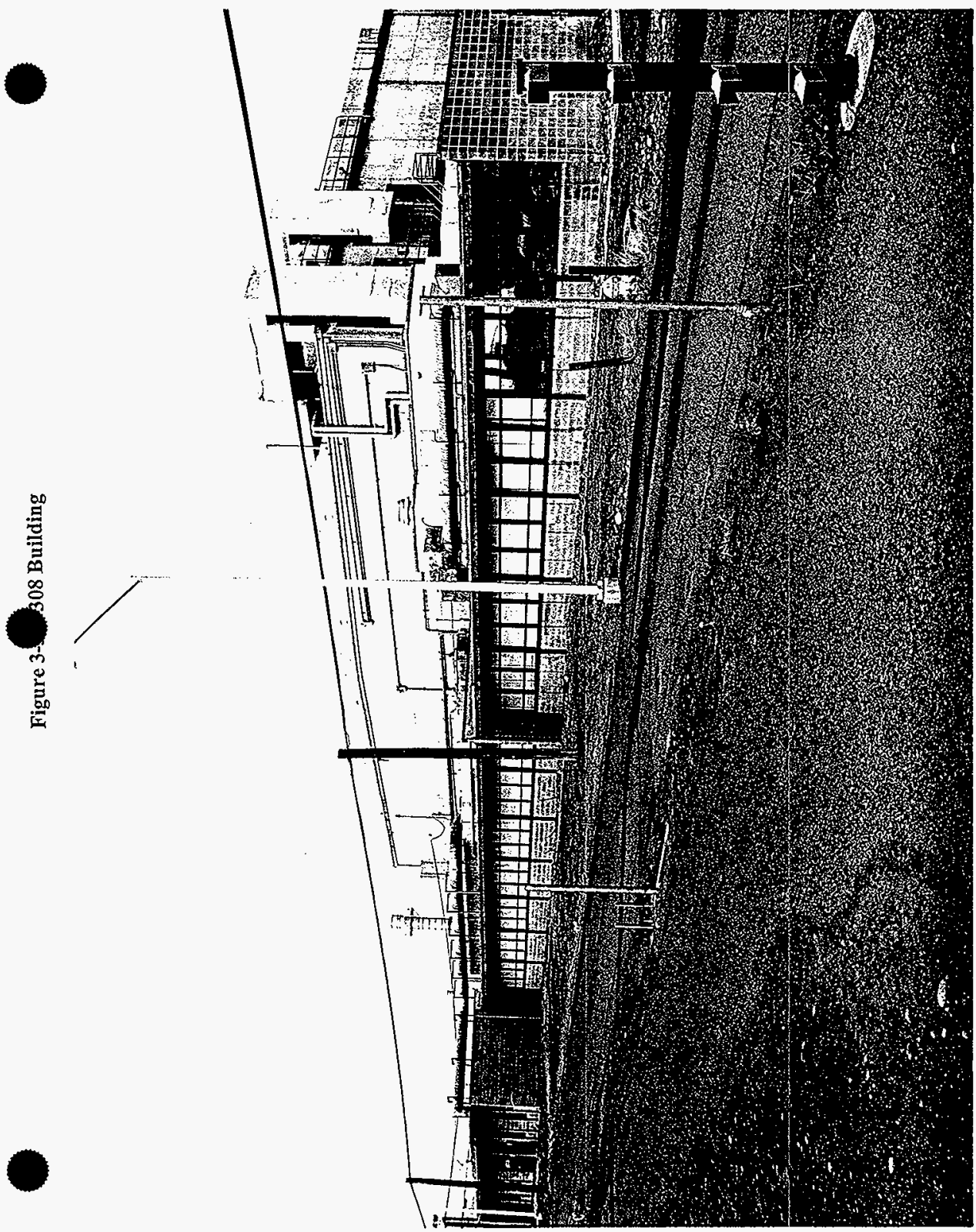
HNF-EP-0649, Rev. 0
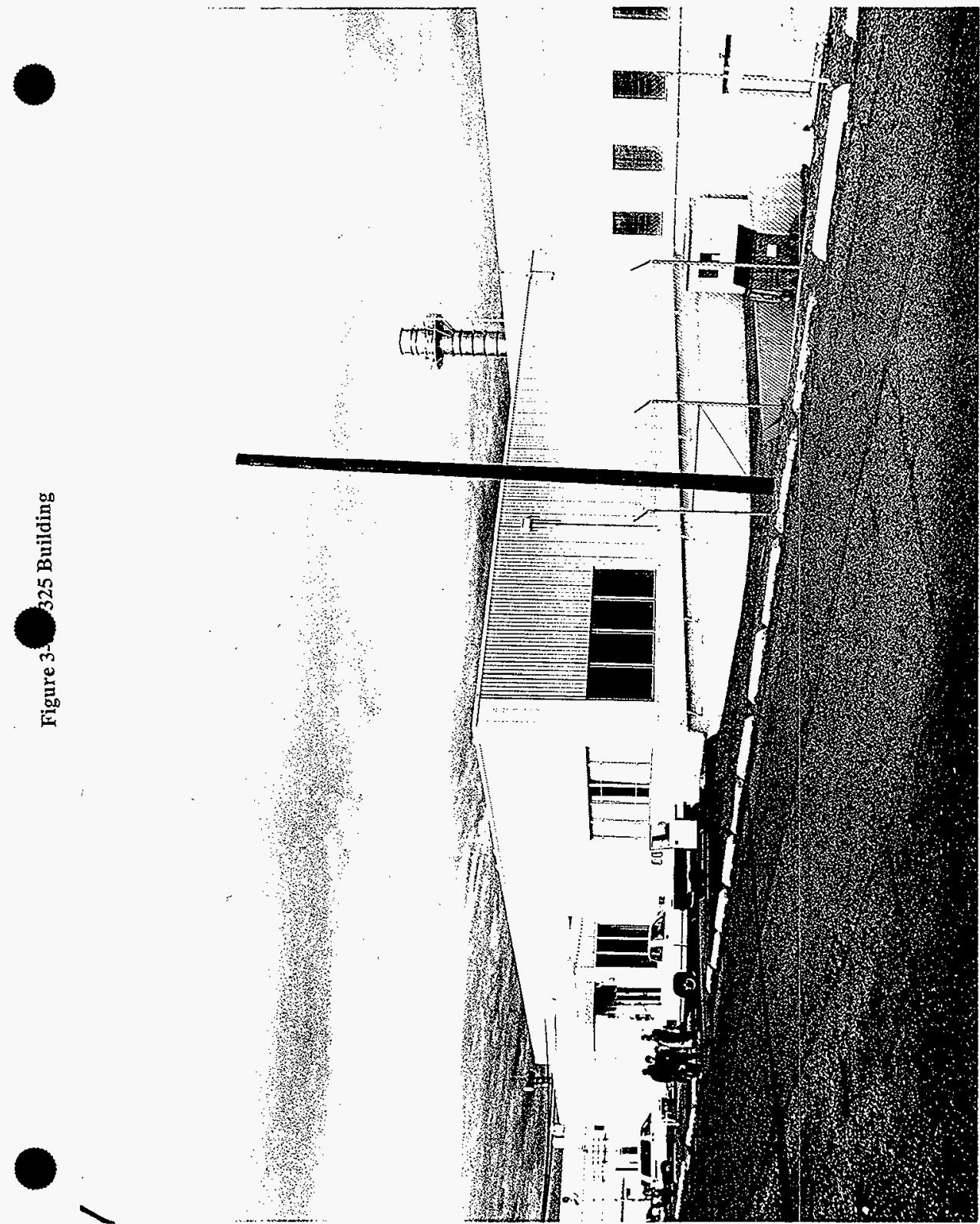
generating building and the luggers were checked on a routine basis, usually weekly or twice a week for more active facilities like the 325 building. Luggers of carton waste at such buildings always appeared full and overflowing. Less active facilities called for service when the lugger approached being full. The system continued to operate in a similar manner when Battelle Laboratories (PNL]) took over most 300 Area operations on January 1, 1965.

The carton waste was dumped or otherwise unloaded into the burial ground trenches (Figure 2-20). A lugger delivered to the 618-11 burial ground was considered to contain 100 feet $^{3}$ of waste, although luggers varied in size and often varied in how they were packed. Many luggers were packed beyond their normal capacity. However, 100 feet $^{3}$ was convenient for accountability (Backman 1964). Transportation workers estimated about 10 luggers were transported weekly to the burial site. This average is supported by Backman for July and August of 1964 (Backman 1964). The PNL radiation monitoring records from 1965 and 1966 (conservative values) indicate that waste was buried from 133 luggers in 1965 and 101 luggers in 1966. This accounted for a total of 23,400 feet $^{3}$ of waste.

Much of the drum storage and caisson disposal work was conducted, or at least coordinated, by employees from the 340 complex (Figure 3-7). Site transportation employees handled waste shipping, but the 340 workers performed most of the actual disposal work activities. Radiation monitoring technicians also accompanied the shipments, or met them at the burial site. As cited in the previous paragraph, some of the few records still available today are radiation survey records. The survey records provide some information on waste movements, shipments, and disposal activities. The records provide good information on the radiation status of the activity, but often contain incomplete shipment and disposal data. It is hoped that the survey records and other related information will help fill gaps in the burial records. 
Figure 3-7: 340 Complex

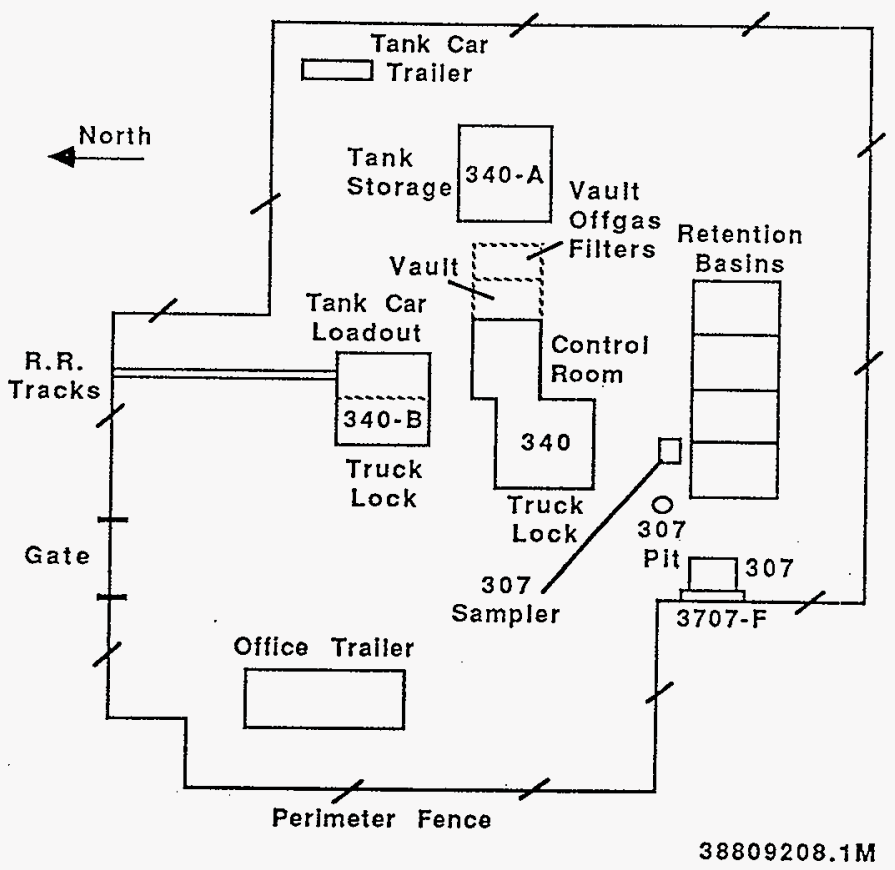


Some activities conducted in 300 Area facilities that would have affected the types and form of waste materials generated are given below:

- Development and fabrication of test reactor fuels

- Determine compositions

- Perform quality control

- Determine physical characteristics

- Determine chemical characteristics

- Measure temperature

- Measure oxygen effects

- Prepare test pins and assemblies

- Conduct fuel tests.

- Cladding and fabrication alloy development

- Work on control rods and reflectors

- Boron carbide

- Cadmium compounds

- Beryllium work

- Radiation damage analyses

- General materials technology improvement

- Special reactor targets

- Radiography

- Metallography

- PUREX reprocessing development

- PUREX waste studies

- Radionuclide separations

- Neptunium recovery

- Cesium and strontium separations

- General analytical support

- Plutonium Recycle Test Reactor (PRTR) operations and support services

- $\quad 340$ Complex decontamination and waste support services 


\subsubsection{History of the PRTR and Fuels Fabrication Facility}

The PRTR started reactor operations in 1960. The Plutonium Fuel Laboratory (PFL) in the 308 building providing the fuel for PRTR. By 1967 , more than $326 \mathrm{~kg}$ of plutonium had been fabricated into PRTR fuel (Wittenbrock 1967). All but the first core was mixed-oxide fuel with the percent plutonium increasing from $0.48 \mathrm{wt} \%$ initially to $5 \mathrm{wt} \%$ and higher (Gerber 1992) before the PRTR was shut down in 1969. Major PRTR facility operation activities are given in Table 3-1.

The PRTR reactor was a vertical pressure tube reactor, moderated and cooled by heavy water. Fuel elements were charged and discharged from the reactor top face through 85 pressure tubes made of Zircaloy-2. The reactor itself was housed in the protective, reinforced-concrete dome that became a 300 Area landmark. A complete description of the facility can be found in the Final Safeguards Analysis (Wittenbrock 1959). The PRTR schematic (Figure 3-4) shows the major reactor areas and the office area that together make up the 309 building.

Initially, the reactor was fueled with plutonium-aluminum alloy elements with sintered uranium dioxide cores. Later, plutonium-uranium dioxide material replaced the metal alloy elements. The oxide material was pressurized water reactor (PWR) grade sintered to 94 percent theoretical density and jacketed with Zircaloy-2. The fuel rods were 0.5 inches in diameter with a 30-or 60-mil jacket, and 7 feet 4 inches long (Wittenbrock 1959). Each succeeding reactor load was fitted with higher plutonium driver amounts.

Solid wastes generated during these operations were primarily disposed to the 618-11 burial ground as laboratory cardboard cartons and an occasional cask. It is calculated that the direct operations at PRTR, the fuel fabrication operations at PFL, and other support services would have incurred at least a 1 -to $2-w t \%$ plutonium operations loss. This generally agrees with fabrication records of the Babcock and Wilcox Plant which incurred about a 2-wt\% process loss on the fabrication of FFTF fuel from Cores 1 and 2 . The 2 percent total was reduced to about 1.5 percent (25 percent reduction) because part of the waste material was designated as scrap and reprocessed for recovery (Bradley 1978). This means that at least 4,875 grams of PRTR plutonium were lost to waste during the fabrication process, assuming a $1.5 \mathrm{wt} \%$ plutonium loss. 
Table 3-1: The Major PRTR Operational Activities Chart.

\begin{tabular}{|c|c|}
\hline Date & Activity \\
\hline 1956 & PRTR Activities Initiated \\
\hline 1958 & $\begin{array}{l}\text { PRTR design completed } \\
\text { PRTR construction started } \\
\text { PRTR start-up tests began }\end{array}$ \\
\hline October 1960 & Initial criticality reached \\
\hline May 1961 & $\begin{array}{l}\text { Full } 70 \mathrm{Mw} \text { power reached } \\
\text { Reactor fuel tests started }\end{array}$ \\
\hline Sept. 1963 & $\begin{array}{l}\text { Rupture loop begins operation } \\
\text { Gas loop tested }\end{array}$ \\
\hline Sept. 1965 & $\begin{array}{l}\text { Major radiation contamination incident } \\
\text { (Type A Event - fuel release, clean-up, and decontamination.) }\end{array}$ \\
\hline July 1966 & Tests resume on batch core experiments \\
\hline Mid-1968 & P-4 Valve problem identified and repairs started. \\
\hline Mid-1969 & $\begin{array}{l}\text { AEC stopped repairs, repairs later completed, and PRTR was } \\
\text { shutdown. }\end{array}$ \\
\hline $1971-1972$ & Fuel shipped to PUREX. \\
\hline 1974 & $\begin{array}{l}\text { Fuel basin clean-out } \\
\text { Dome as a clean shop }\end{array}$ \\
\hline
\end{tabular}

The fuel fabrication process for PRTR included converting the material to oxide or another fuel form, making pellets, encapsulating the pellets, analyzing the fuel, performing physical tests and measurements, and doing metallography. Figure 3.8 shows a schematic of the first floor of the 308 building where the PRTR fuel was fabricated. 


\section{Plutonium Fuels Pilot Plant}

(First Floor)

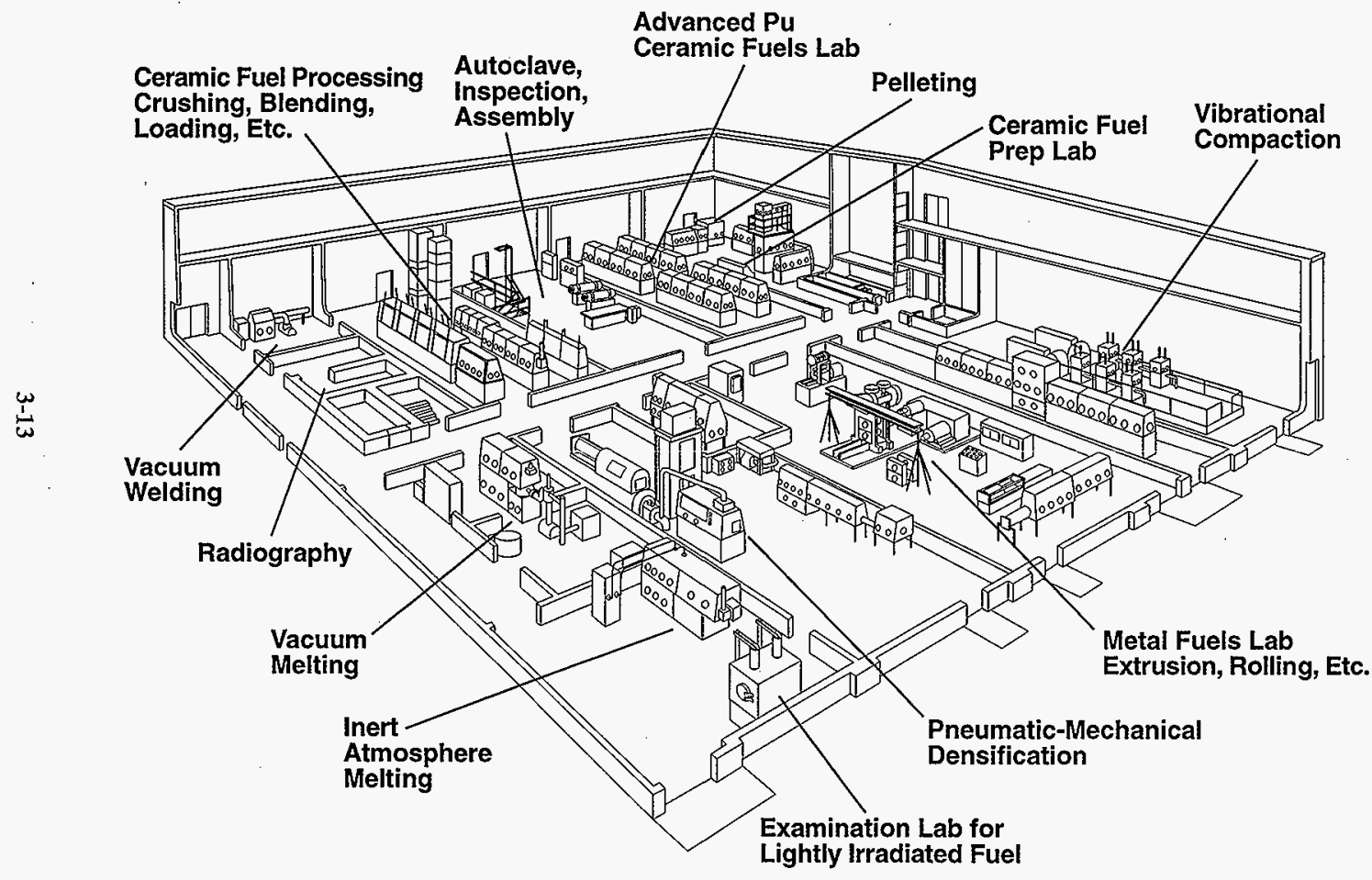


HNF-EP-0649, Rev. 0

Most of the recognized plutonium waste generated from the 308 building went to the 200 West disposal areas, particularly in the later years. Non-fabrication and support service waste went primarily to the $618-11$ burial ground. The 308 building shipped about half the waste carton material to the 200 West Area for disposal. The remaining waste was shipped to either the 618-10 or 618-11 burial ground. Other buildings and facilities including 327, 326, PRTR (309), $3706,340,321$, and 324 , shipped their waste to the $618-10$ or $618-11$ burial ground. The 325 building shipped carton waste primarily to the $618-11$ or $618-10$ burial grounds, but a small fraction of the waste cartons and a sizeable fraction of the concreted drums went to the 200 West Area burial grounds. (see Section 3.1.2) It was primarily the fuel fabrication operation, located in 308 and the basement of the 325 building, which sent waste to the 200-West Area.

The balance of the PRTR support organizations, including reactor operations, sent waste materials to the 618-11 burial site for disposal. Therefore, it is estimated that at least half of the projected plutonium in PRTR wastes, about 2,400 grams, was disposed to the 618-11 facility. The balance of the PRTR plutonium is at the 200 West burial trenches, or the $618-10$ burial facility. Very little 300 Area waste went to the 200-West burial ground until late 1963 or early 1964.

\subsubsection{History of the 325 Building from 1962 to 1968}

The 325 building was constructed in 1953. A large addition, known as the high-level radiochemistry (325-A hot cells), was constructed on the east end from 1959 to 1960 . The 325 building was one of the 300 Area facilities transitioned to PNL from General Electric at the beginning of 1965. A simple schematic of the hot cell and waste handling areas is shown in Figure 3-9. A detailed map of the main floor area is shown in Figure 3-10.

Activities in the 325 building consisted primarily of $\mathrm{R} \& \mathrm{D}$, fuel reprocessing studies, isotope separations, analytical support, and ceramic fuels work. The R\&D and related work was carried out primarily on the main floor in the middle and the east portions of the building. The analytical support work was conducted at the west end of the main floor. The ceramic fuels work and fuel material storage were in the basement. Some R\&D and related work was associated with the 325-A hot cell. The 325-A hot cells consisted of A-cell, $\mathrm{B}$-cell, and C-cell. The timeline and general activities carried out in these hot cells are listed in Table 3-2. A series of gloveboxes in the northeast corner of the building were used to conduct work in support of the hot cell operation. In addition, another series of hot cells known as the Analytical hot cells, or 325-B hot cells, were located at the far west end of the building. These hot cells supported the operation of the 325-A cells, and analyzed samples, primarily from $325-\mathrm{A}$ cells.

The operations in the 325-A hot cells consisted primarily of pilot-scale and small plant-size production tests. Fuel reprocessing or radionuclide separation campaigns were also typical work 
Figure 3-9: 325 Radiochemistry Building

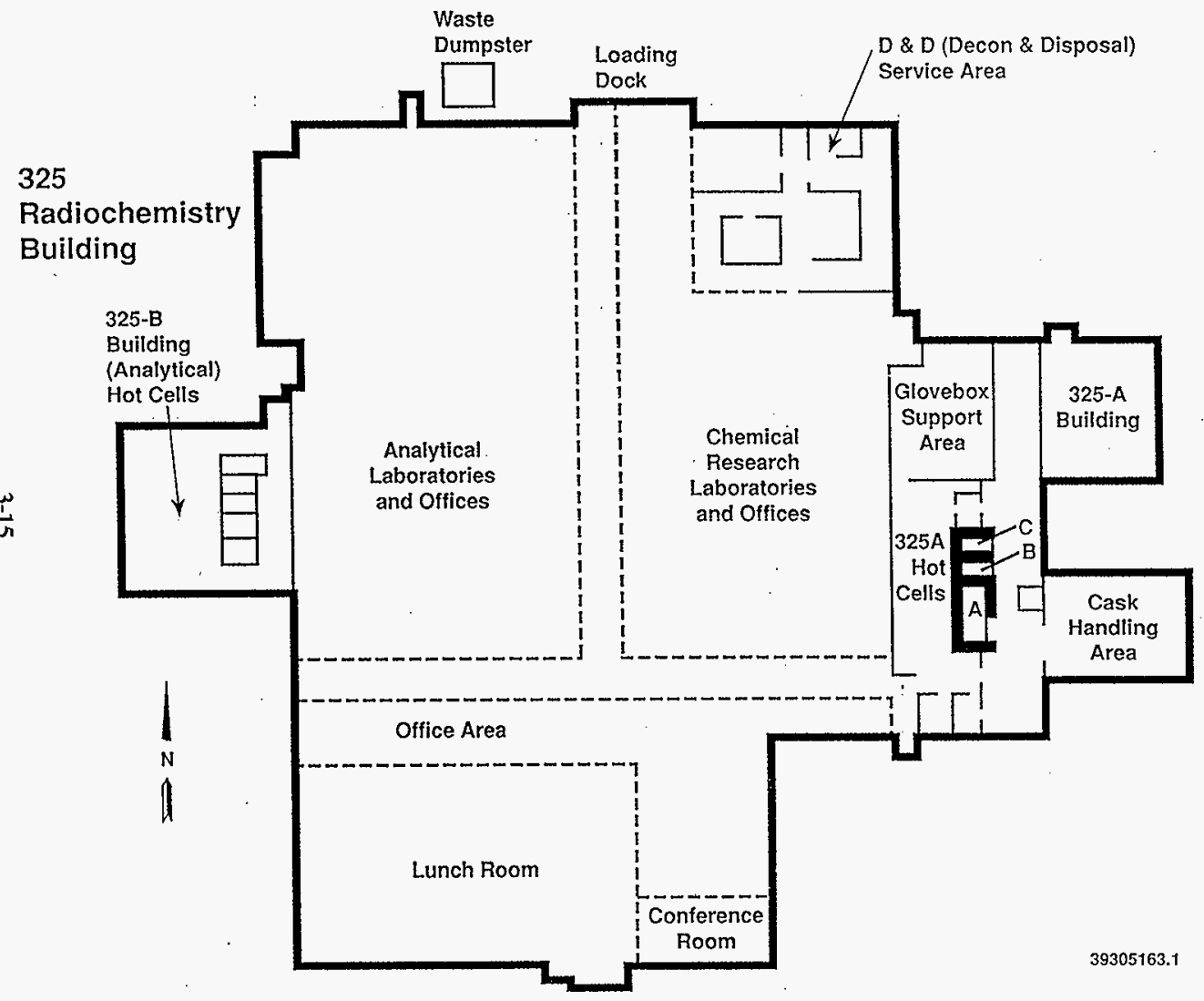


Figure 3-10: 325 Building - First Floor

\section{Building - First Floor}

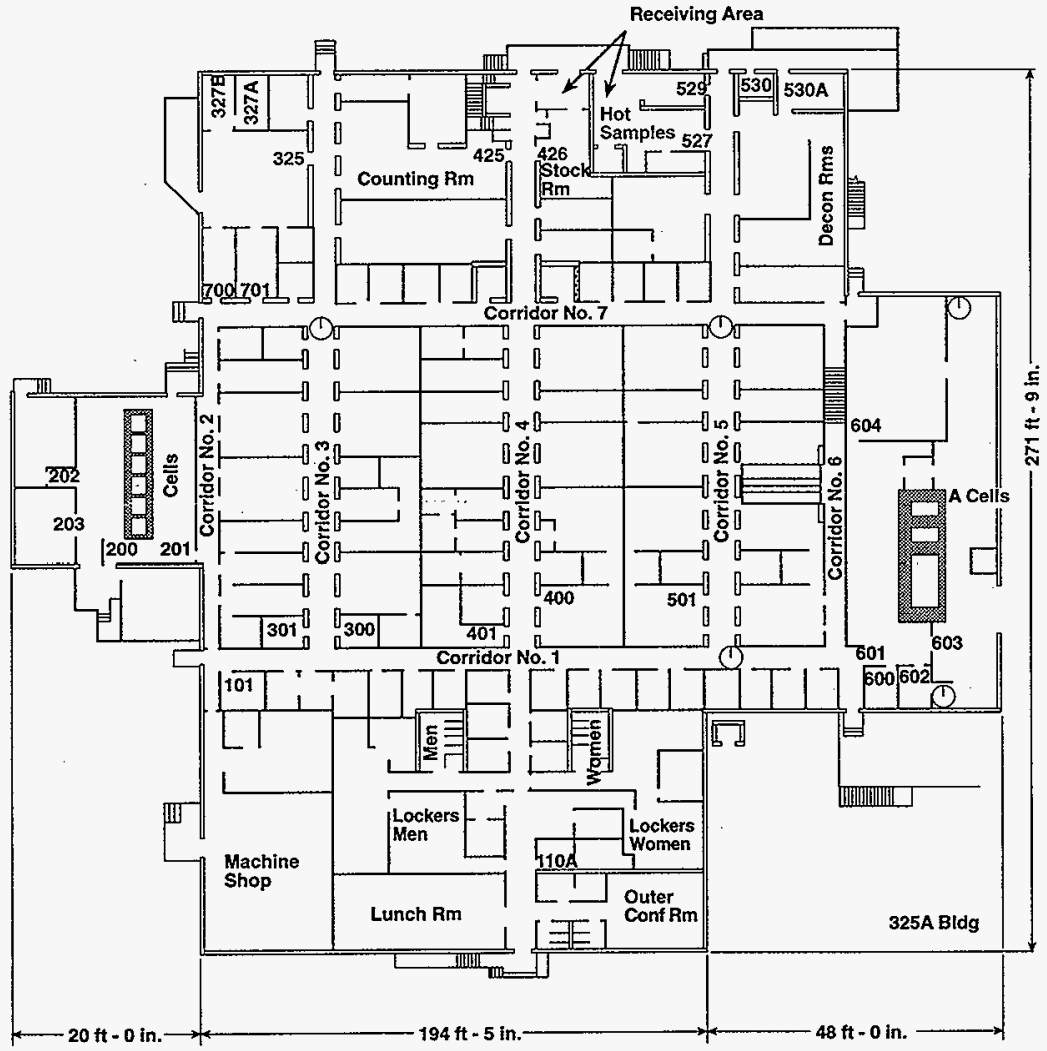

First Floor Plan

$\begin{array}{lll}0 & 16 \quad 32 \mathrm{ft}\end{array}$ 
activities (Table 3-2). A substantial fraction of the caisson waste disposed at the 618-11 burial ground was generated in the 325-A hot cell operations. Most of the concrete-shielded waste drums disposed in the 618-11 trenches were also generated in the 325-A hot cells. About 10 percent of the 325 building remote-handled waste was generated in the analytical hot-cells, including both caisson and concreted drum waste. 
Table 3-2: 325-A Hot Cells - Work Activities

\section{A-Cell}

Special Projects

1. Ion-Exchange Pilot Plant (1960-1962) Purified 1st $75,000 \mathrm{Ci}^{90} \mathrm{Sr}$ for RTGs

- 1st Macro-Scale ${ }^{147} \mathrm{Pm}$ Purification

2. Waste Solidification (1962-1964)

- 1st Spray Calcination (200 gal) of PUREX 1WW

- Demonstration of Phosphate Glass Melter

3. Ion-Exchange Pilot Plant (1964-1977) - Recovered and Purified 14 Million Curies ${ }^{147} \mathrm{Pm}$

$\omega$. Purified $1 \mathrm{~kg}^{90} \mathrm{Sr}$

䀜 . Purified $65 \mathrm{gm}^{244} \mathrm{Cm}$ from

Shippingport Waste

- Purified $3 \mathrm{~kg}^{2 * 1} \mathrm{Am}$

4. Nuclear Waste Vitrification Project (1977-1980)
B-Cell

General Purpose Lab Work

1. B-Plant Flowsheet Development

Cs Precipitation

- Cs Ion Exchange

Sr Recovery by Pb Sulfate

Carrier Precipitation

2. High-Level Waste Behavior During

Thermal Concentration

3. LWR Fuel Dissolution Tests for Waste Partitioning

\section{C-Cell \\ Special_Projects}

1. Demonstration Molten Salt Electro-deposition of $\mathrm{UO}_{2}-\mathrm{PuO}_{2}$ (1960-1963)

2. Recovery of ${ }^{237} \mathrm{~Np}$ and ${ }^{238} \mathrm{Pu}$ from Special Target Material (1964-1966)

3. Solvent Degradation Tests for LMFBR Processing (1966-1970)
4. $\mathrm{SrF}_{2}$ Capsule Development

5. CsCl Capsule Development
4. Recovery of Medical-Grade ${ }^{233} \mathrm{Pu}$ From Special Targets (1972-1973)

5. Preparation of Capsules for $\mathrm{SrF}_{2}$ Compatibility Testing (1973-1977)

6. Nuclear Waste Vitrification Project (1977-1980)

NWVP equipment placed on standby by DOE Order in 1980. The limited available space has been used since that date for the following programs:

1. MCC Leach Tests of Waste Glass

2. MCC Leach Tests of Spent Fuel

3. Post Irradiation Examination of N-Reactor Boron Thermal Shicld

4. Characterization of NCRW

5. Tests on RHO Flowsheet for Converting NCRW to Non-TRU
6. Characterization of Tank Farm Double-Shell Slurry

7. N-Reactor Fuel Yodine Control Tests

8. N-Reactor Fuel Uranium Dissolution Tests

9. Recovery of Sr Using Antimonic Acid 
Appendix A contains detailed information of all 325-A hot cell wastes disposed between April 1961 and December 1967. The information was taken from PNL 325-A operations shift $\log$ books by an employee who worked in the 325-A hot cells during the entire period. A summary of Appendix A data is given in Table 3-3, delineating wastes that went to 618-10 or $618-11$ burial grounds. Approximately $167 \mathrm{~m}^{3}$ of waste was deposited in the $618-11$ burial ground facility from the 325-A hot cells.

The radioactive solid wastes typically generated in the 325 building laboratories were discarded into polyethylene plastic-lined cardboard cartons (see Appendix C). The typical size of the cartons were 18 inches by 18 inches by 24 inches with a computed volume of 4.5 feet $^{3}$. Cardboard cartons of other sizes were sometimes used for spent CWS filters and similar wastes. This type of package represents some of the more common pre-1970 TRU waste.

During this time, radioactive wastes such as TRU, byproduct, or fission-product material were not segregated. However, plutonium and byproduct materials were classified as special nuclear material (SNM), and therefore were accountable. Plutonium, $U^{235}$, and $U^{233}$ are fissile materials and are accountable to the nearest gram. Byproduct material included natural uranium, depleted uranium, and thorium. These materials were accountable to the nearest pound. Waste cartons and other waste containers having appreciable gram quantities of plutonium, and fissile materials were to be labeled with the value of fissile material being disposed. Fissile values were also to be written off respective SNM inventory records. Likewise, waste packages containing pound quantities of byproduct material were to be labeled with SNM content. SNM inventories of byproduct materials were to be adjusted appropriately. Burial records were expected to contain this information, but lack of this type of information indicates that many SNM contents were not reported or not recorded. SNM inventory writeoff values were estimates at best, and probably were more closely related to SNM accountability than to actual waste contents. Safeguard accountability records for the 300 Area would have provided a good estimate of the amount of plutonium disposed in the waste, but the records have been destroyed.

The cartons and other waste packages were taken to the back of the building and loaded in a labeled load lugger (Figure 2-27). These were routinely emptied once a week and sometimes more often if there was a scheduled cleanup. It was sometimes difficult to make efficient use of the lugger space. However, disposal of spent CWS filters in cartons of varying size helped in packing the load lugger. Spent CWS filter cartons were approximately 12 inches by 24 inches by 24 inches and occupied about 4.0 feet $^{3}$. 
HNF-EP-0649, Rev. 0

Table 3-3 - 325A Hot Cells Disposal Record, 1961-1967

\begin{tabular}{|c|c|c|c|c|c|c|c|c|c|c|c|c|c|c|c|}
\hline YEAR & $\begin{array}{l}\text { CULVERT } \\
\text { 55-GAL } \\
\text { DRUM } \\
\end{array}$ & $\begin{array}{l}\text { 1" LEAD } \\
\text { 55-GAL } \\
\text { DRUM }\end{array}$ & $\begin{array}{l}2^{\prime \prime} \text { LEAD } \\
\text { 55-GAL } \\
\text { DRUM }\end{array}$ & $\begin{array}{l}\text { 1-GAL } \\
\text { PAINT } \\
\text { CAN }\end{array}$ & $\begin{array}{l}\text { 5-GAL } \\
\text { PAINT } \\
\text { CAN } \\
\end{array}$ & $\begin{array}{l}\text { 15-GAL } \\
\text { BLACK } \\
\text { IRON }\end{array}$ & $\begin{array}{l}\text { 15-GAL } \\
\text { RESIN SST } \\
\text { CAN }\end{array}$ & $\begin{array}{l}\text { C.W.S. } \\
\text { FILTER }\end{array}$ & $\begin{array}{l}4^{\prime} \times 4^{\prime} \times 8^{\prime} \\
\text { WOOD BOX }\end{array}$ & $\begin{array}{l}8^{\prime \prime} \times 20 " \times 28 " \\
\text { WOOD BOX }\end{array}$ & WOOD BOX & $\begin{array}{l}\text { 55-GAL } \\
\text { DRUM }\end{array}$ & $\begin{array}{l}\text { WASTE } \\
\text { CARTONS }\end{array}$ & MISCELLANEOUS & \\
\hline $1961 \mathrm{~A}$ & [2] & [3] & {$[1]$} & [2] & & & & & & & & & {$[7]$} & & \\
\hline B & [6] & [8] & [5] & & & & & [9] & [1] & & & [2] & & & \\
\hline $1962 \mathrm{~A}$ & $\begin{array}{l}{[7]} \\
\text { (3) }\end{array}$ & [5] & & & (3) & [1] & & $\begin{array}{l}{[1]} \\
(1)\end{array}$ & (1) & $\begin{array}{l}\text { (25) - LEAD } \\
\text { BRICKS }\end{array}$ & $\begin{array}{l}\text { (6) - GLASS } \\
\text { PIPES } \\
\text { 4" OD X } 9 \mathrm{ft}\end{array}$ & & & $\begin{array}{l}\left.\text { (Box } 30^{\prime \prime} \times 30^{\prime \prime} \times 35^{\prime \prime}\right) \\
(30 \text { gal drums }-2 \text { each) } \\
\text { (20 gal steel tanks - } 4 \text { each) }\end{array}$ & \\
\hline B & [6] & $\begin{array}{l}{[5]} \\
(1) \\
\end{array}$ & & & [3] & & & $\begin{array}{l}{[9]} \\
(14) \\
\end{array}$ & [2] & & & {$[3]$} & [4] & & \\
\hline $1963 \mathrm{~A}$ & {$[15]$} & [11] & [4] & & & & & [11] & [3] & & & & & $\begin{array}{l}{\left[B o x 3^{\prime} \times 3^{\prime} \times 6^{\prime}\right]} \\
{\left[3^{\prime \prime} \text { lead drum] }\right.}\end{array}$ & \\
\hline B & $\begin{array}{l}{[2]} \\
(6) \\
\end{array}$ & $\begin{array}{l}{[3]} \\
(4) \\
\end{array}$ & $\begin{array}{l}{[1]} \\
(2) \\
\end{array}$ & & & & & $\begin{array}{c}{[1]} \\
(16) \\
\end{array}$ & & & & & & & \\
\hline $1964 \mathrm{~A}$ & & & & (98) & (2) & (22) & & (35) & & & & & & & \\
\hline B & & & & (32) & (36) & (2) & & (37) & & & & & (4) & & \\
\hline $1965 \mathrm{~A}$ & & & & (5) & (12) & $(42)$ & & (29) & (17) & & & & & $\left(2\right.$ Boxes $\left.-2^{\prime} \times 3^{\prime} \times 4^{\prime}\right)$ & \\
\hline B & & & & & (10) & $(50)$ & & (8) & (8) & & & & & & \\
\hline $1966 \mathrm{~A}$ & & & & & (19) & (10) & (2) & (6) & (1) & & & & & & \\
\hline B & & & . & & (24) & (2) & (8) & - & & & & & & (14) - 40 gal tanks & \\
\hline $1967 \mathrm{~A}$ & & & & & (58) & (4) & (9) & (17) & & & & (1) & (5) & $\begin{array}{l}\text { (2) Wood boxes - glass pipe } \\
16^{n} \text { OD } \times 9 \mathrm{ft} \\
8^{n} \text { OD } \times 9 \mathrm{ft}\end{array}$ & \\
\hline B & & & & & (84) & & (19) & (12) & (5) & & & & & & \\
\hline TOTAL & $\begin{array}{l}{[38]} \\
(9) \\
\end{array}$ & $\begin{array}{c}{[35]} \\
(5)\end{array}$ & $\begin{array}{l}{[11]} \\
(2)\end{array}$ & $\begin{array}{c}{[2]} \\
(135) \\
\end{array}$ & $\begin{array}{c}{[3]} \\
(248) \\
\end{array}$ & $\begin{array}{c}{[1]} \\
(132) \\
\end{array}$ & (38) & $\begin{array}{r}{[31]} \\
(175) \\
\end{array}$ & $\begin{array}{l}{[6]} \\
(32) \\
\end{array}$ & $(25)$ & (6) & $\begin{array}{l}{[5]} \\
(1) \\
\end{array}$ & $\begin{array}{l}{[11]} \\
(9) \\
\end{array}$ & $\begin{array}{l}{[2]} \\
(15) \\
\end{array}$ & Totals \\
\hline $\begin{array}{l}\text { Volume } \\
\left(\mathrm{ft}^{3}\right)\end{array}$ & $\begin{array}{r}{[285]} \\
(67.5) \\
\end{array}$ & $\begin{array}{l}{[262.5]} \\
(37.5)\end{array}$ & $\begin{array}{l}{[82.5]} \\
(15.0) \\
\end{array}$ & $\begin{array}{r}{[0.3]} \\
(18.4) \\
\end{array}$ & $\begin{array}{c}{[2.0]} \\
(168.6) \\
\end{array}$ & $\begin{array}{c}{[2.0]} \\
(269.3) \\
\end{array}$ & $(77.5)$ & $\begin{array}{l}{[124]} \\
(700) \\
\end{array}$ & $\begin{array}{r}{[768]} \\
(4096) \\
\end{array}$ & (64.8) & (4.7) & $\begin{array}{l}{[37.5]} \\
(7.5) \\
\end{array}$ & $\begin{array}{l}{[49.5]} \\
(40.5) \\
\end{array}$ & $\begin{array}{l}{[61.5]} \\
(126)\end{array}$ & \\
\hline $\begin{array}{l}\text { Volume } \\
\left(\mathrm{m}^{3}\right)\end{array}$ & $\begin{array}{l}{[8.077} \\
(1.91) \\
\end{array}$ & $\begin{array}{l}{[7.43]} \\
(1.06)\end{array}$ & $\begin{array}{l}{[2.33]} \\
(0.42)\end{array}$ & $\begin{array}{l}{[0.01]} \\
(0.52)\end{array}$ & $\begin{array}{c}{[0.057]} \\
(4.77) \\
\end{array}$ & $\begin{array}{c}{[0.057]} \\
(7.62)\end{array}$ & $(2.19)$ & $\begin{array}{r}{[3.51]} \\
(19.81) \\
\end{array}$ & $\begin{array}{r}{[21.73]} \\
(115.92) \\
\end{array}$ & (1.83) & $(0.13)$ & $\begin{array}{l}{[1.06]} \\
(0.21) \\
\end{array}$ & $\begin{array}{l}{[1.40]} \\
(1.15) \\
\end{array}$ & $\begin{array}{l}{[1.74]} \\
(3.57) \\
\end{array}$ & $\begin{array}{l}{[47.39]} \\
(161.11) \\
\end{array}$ \\
\hline
\end{tabular}

$A=$ First half of year

$\mathrm{B}=$ Second half of year

Brackets [ ] refer to 618-10 Burial ground
Parentheses ( ) refer to 618-11 Burial ground 
Radioactive laboratory liquid wastes were routinely discharged to the contaminated sewer system now known as the radioactive liquid waste system (RLWS) and went to the 340 building. Any significant discharge of plutonium material to the liquid waste steam was prohibited unless approved ahead of time. Criticality limitations restricted the waste in the RLWS system to less than $15 \mathrm{~g}$ fissile per tanker truck ( 8,000 gallons maximum) or rail tanker load $(20,000$ gallons maximum).

The liquid waste was collected in holding tanks located in the 340 building where it was neutralized and the $\mathrm{pH}$ adjusted to basic levels in a large mixing tank. The neutralized waste was then loaded into tanker trucks (later rail tankers) for shipment to the 200 Area for concentration by evaporative processing. The liquid concentrate was stored in underground tanks now known as single-shell tanks. Buildings that were serviced by the RLWS system included 327, 326, 325 (including both hot cell areas), 324, 309, and 308, and the decontamination area of 340 (Lust 1976). Potential (but normally non-radioactive) liquid waste was discharged to the retention waste system (BNWL 1967). The retention waste was monitored for radioactivity and if non-radioactive, was discharged to the process sewer system. If the retention waste was found to be radioactive, it was retained and processed in the RLWS system. No appreciable plutoniumcontaminated waste would have been discharged in this manner.

The other solid and liquid radioactive waste generated in the building comprised moderate and high-activity wastes. This specialized waste was generated primarily from the hot cell areas, either the 325-A hot cell or the 325-B hot cells. Initially, the typical hot cell waste was cut up and placed in one gallon cans, which were placed in a concrete and/or concrete/lead shielded drum. Wastes in these shielded 55-gallon drums were disposed of to the 618-10 or 618-11 trenches. Later, casks were designed that held larger waste containers; five gallon cans for high-activity wastes and 15-gallon cans for lower activity waste and spent equipment. Beginning January 1964, the one gallon cans were disposed using the new one ton cask. The use of the cask made it possible to use fewer shielded drums. However, concrete-shielded drums continued to be used for some cell waste through the 1960s and 1970s. March 1964 began the shipment of five and 15-gallon containers to the burial grounds using the new seven-ton cask (Figures 2-9 and 2-21). The wastes were loaded out the side of the cells into the horizontally positioned cask, and shipped vertically on a flatbed truck trailer to the 618-11 burial ground. One 15-gallon drum disposed of spent resin while the other disposed of larger equipment and hardware.

The concrete drums were also used to dispose of small volume liquid wastes that were either highly radioactive, had a high plutonium content $(>15 \mathrm{~g})$, or contained contaminated oil or organics. Sealed liquid bottles were placed in the center of a concrete drum, and concrete was poured on top to seal them (Lust 1976). The concrete was mixed in Room 530, and the drums filled in an open hot cell facility with a portable commercial cement mixer. Weights, volumes, and quantities of waste generated at the 325 building are discussed in Section 3.2. Some 
325-A hot cell wastes. Much of the equipment is stainless steel with tubing, glass, tanks, wiring, insulation, valves, pumps, and motors. The rest is miscellaneous pressure, vacuum, flow, and temperature support equipment. Much of the waste is contaminated and may harbor significant SNM material. Hundreds of thousands of curies of various radionuclides have been disposed of, but with several half-lives completed, the activity is down to only thousands of curies. 


\section{SALT CYCLE PROCESS CONCEPTUAL FLOWSHEET}

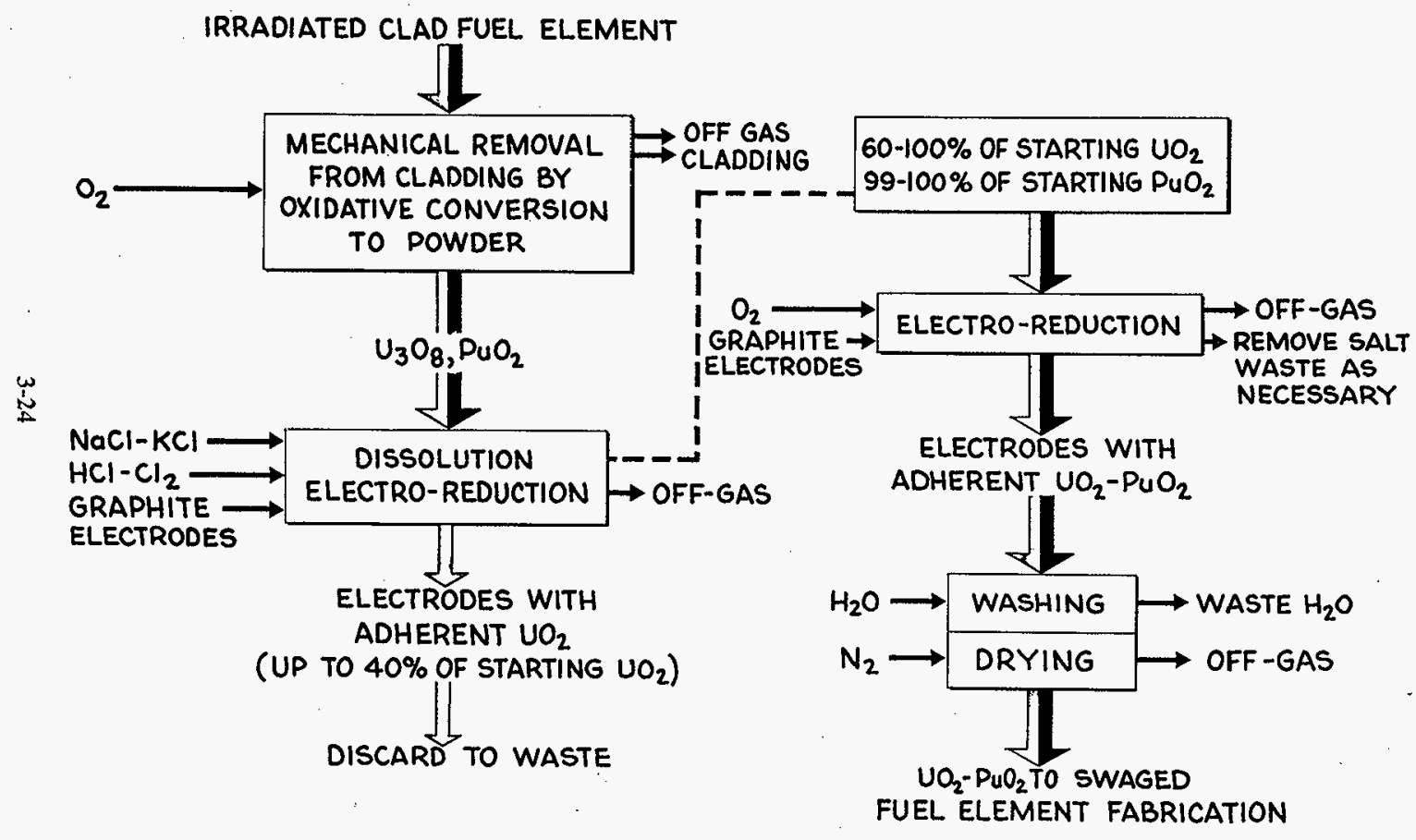


Figure 3-12: Approximate Composition of PUREX 1WW

\section{APPROXIMATE COMPOSITION OF PUREX IWW}

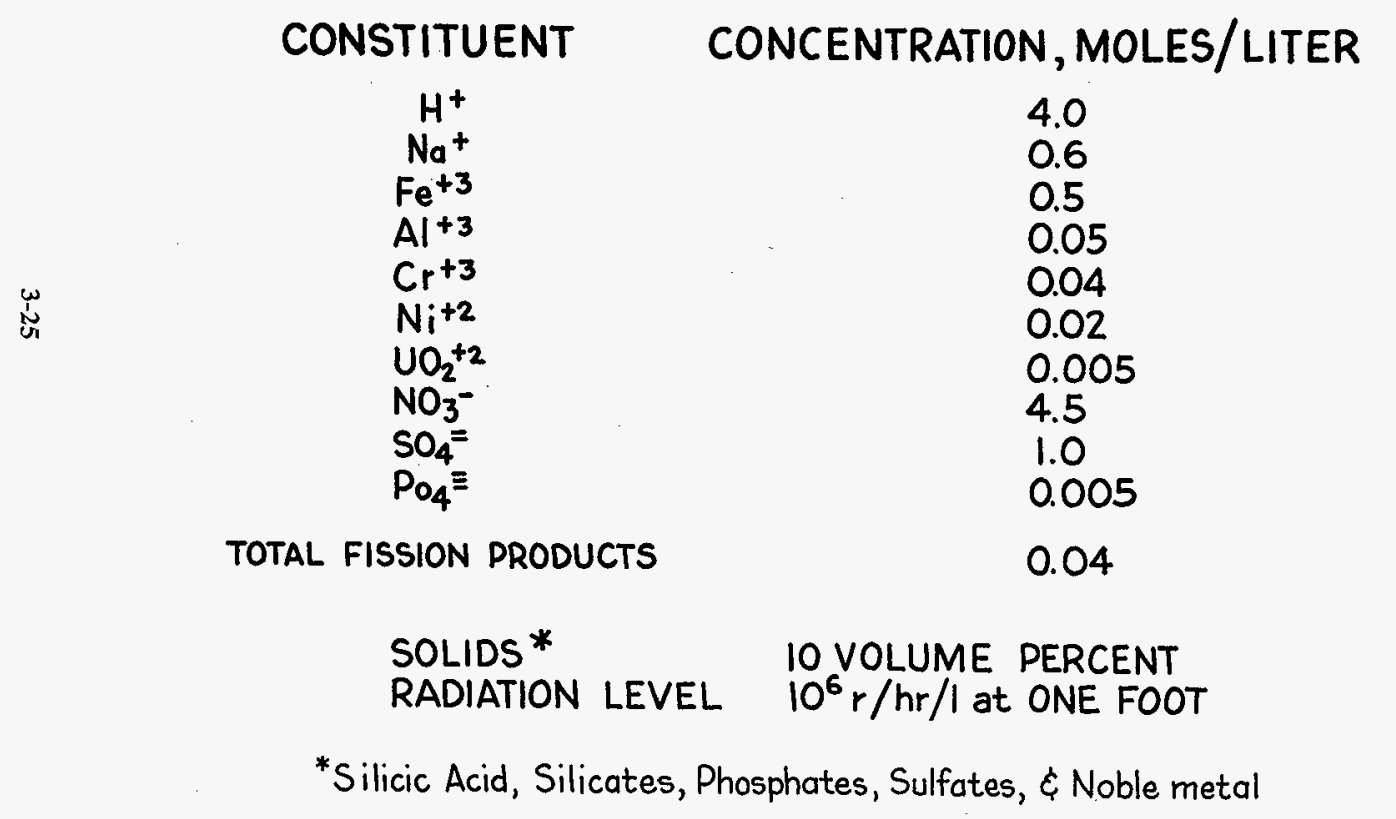


Figure 3-13: PUREX Plant Strontium Discovery Flowsheet

\section{PUIREX PLANT STRONTIUM RECOVERY FLOWSHEET}

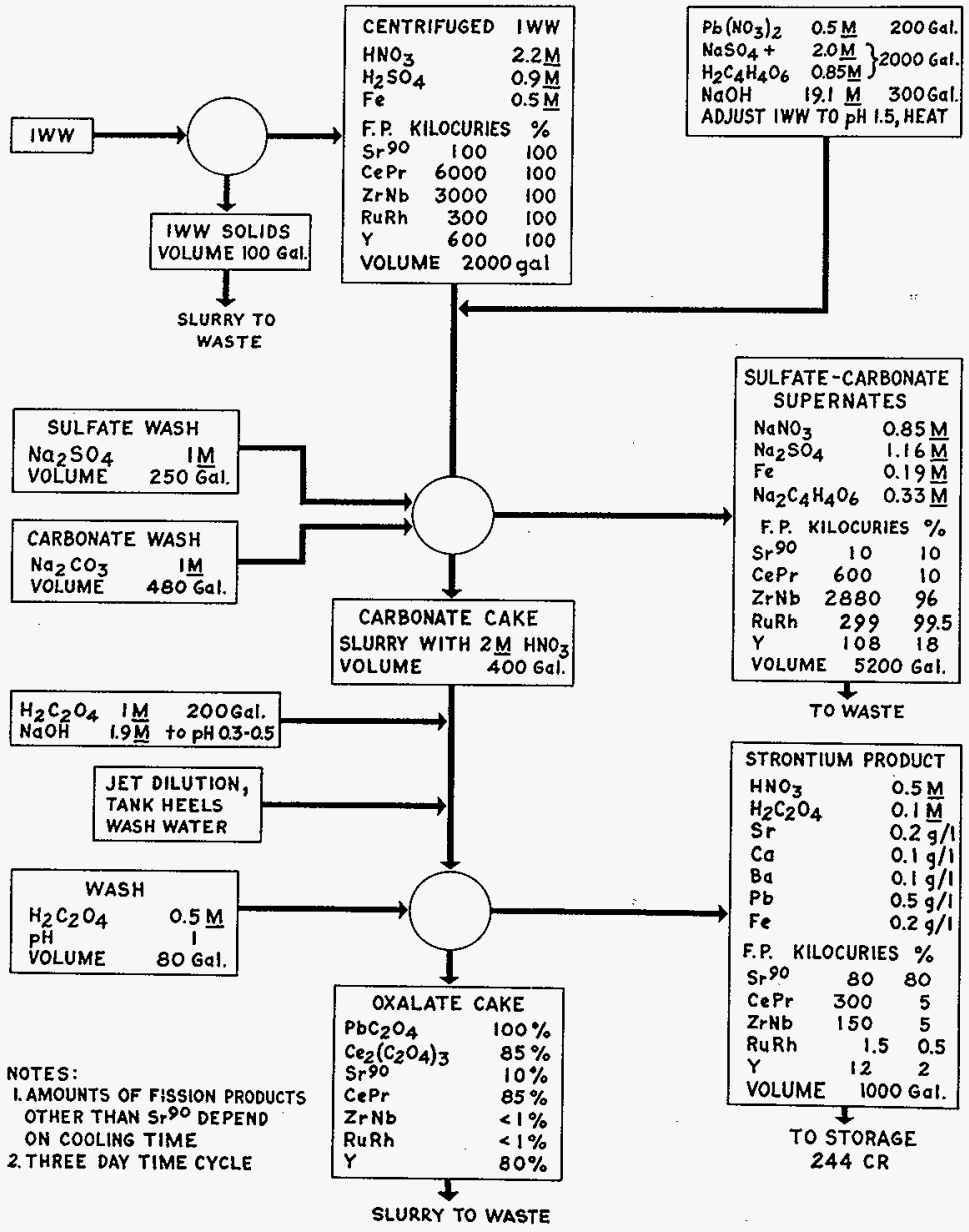


Figure 3-14: "A" Cell Spray Calciner Mock Up

HNF-EP-0649, Rev. 0

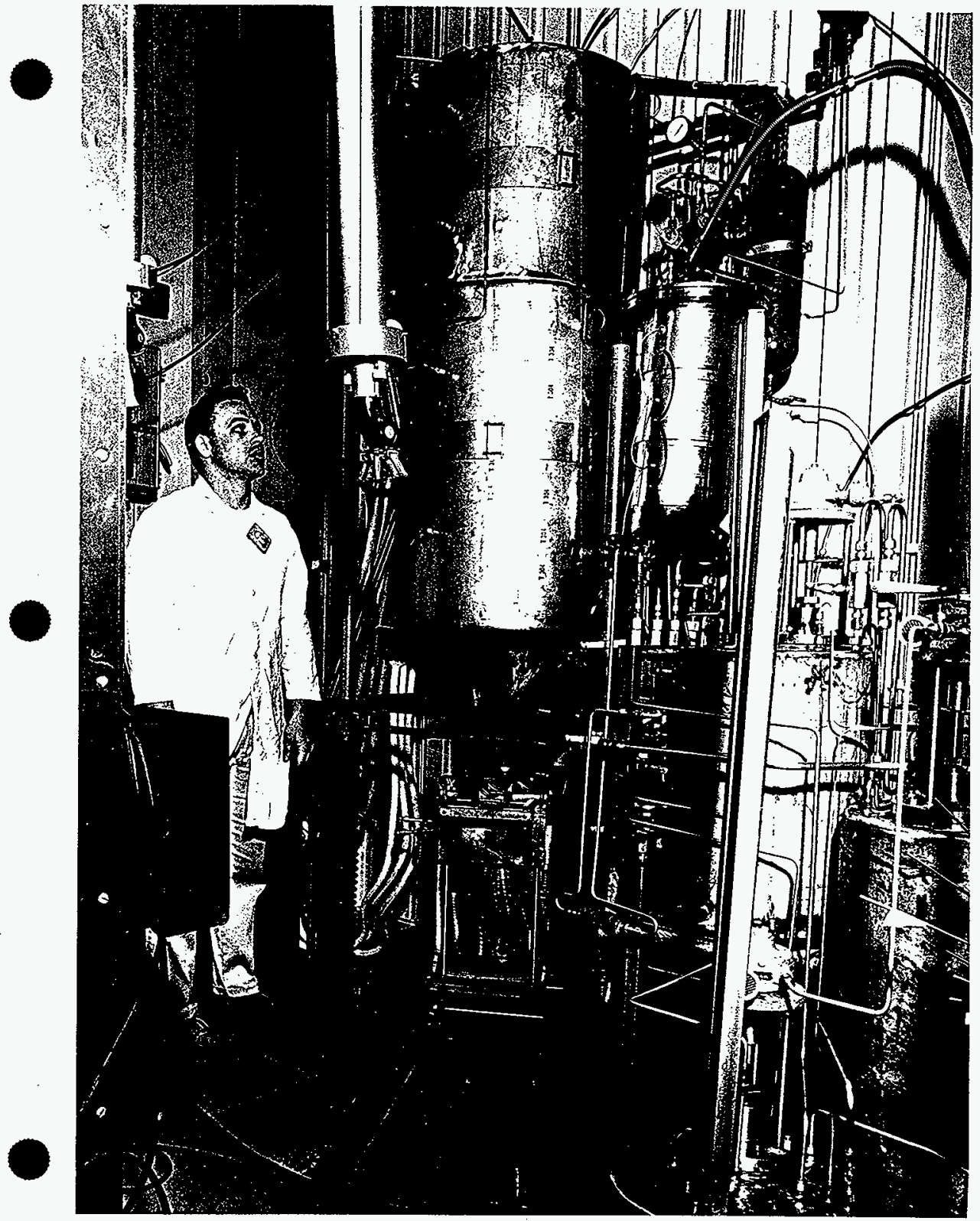


Figure 3-15: Spray Calciner in "A" Cell (1962-1964) Equipment Buried in 1965

HNF-EP-0649, Rev. C

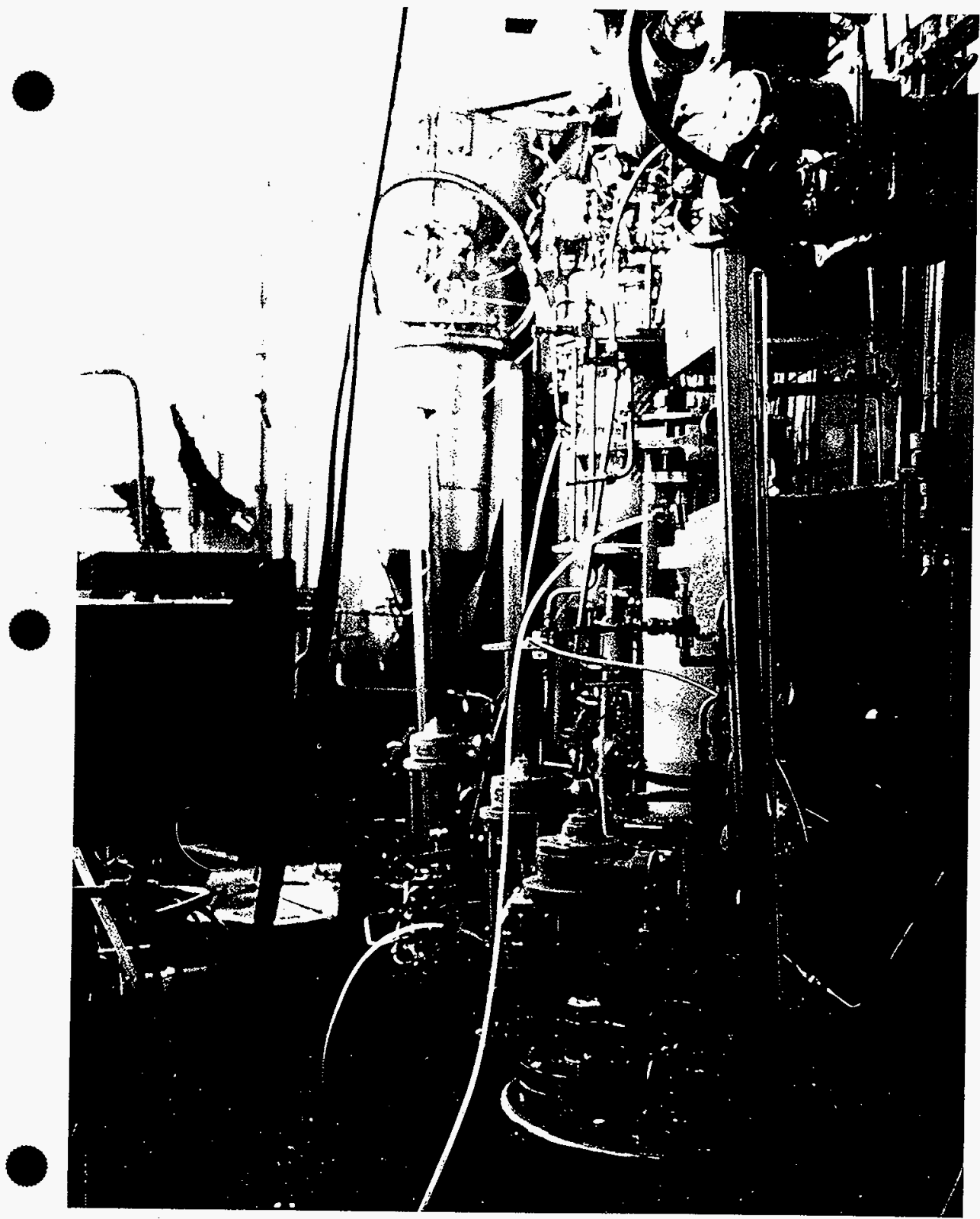




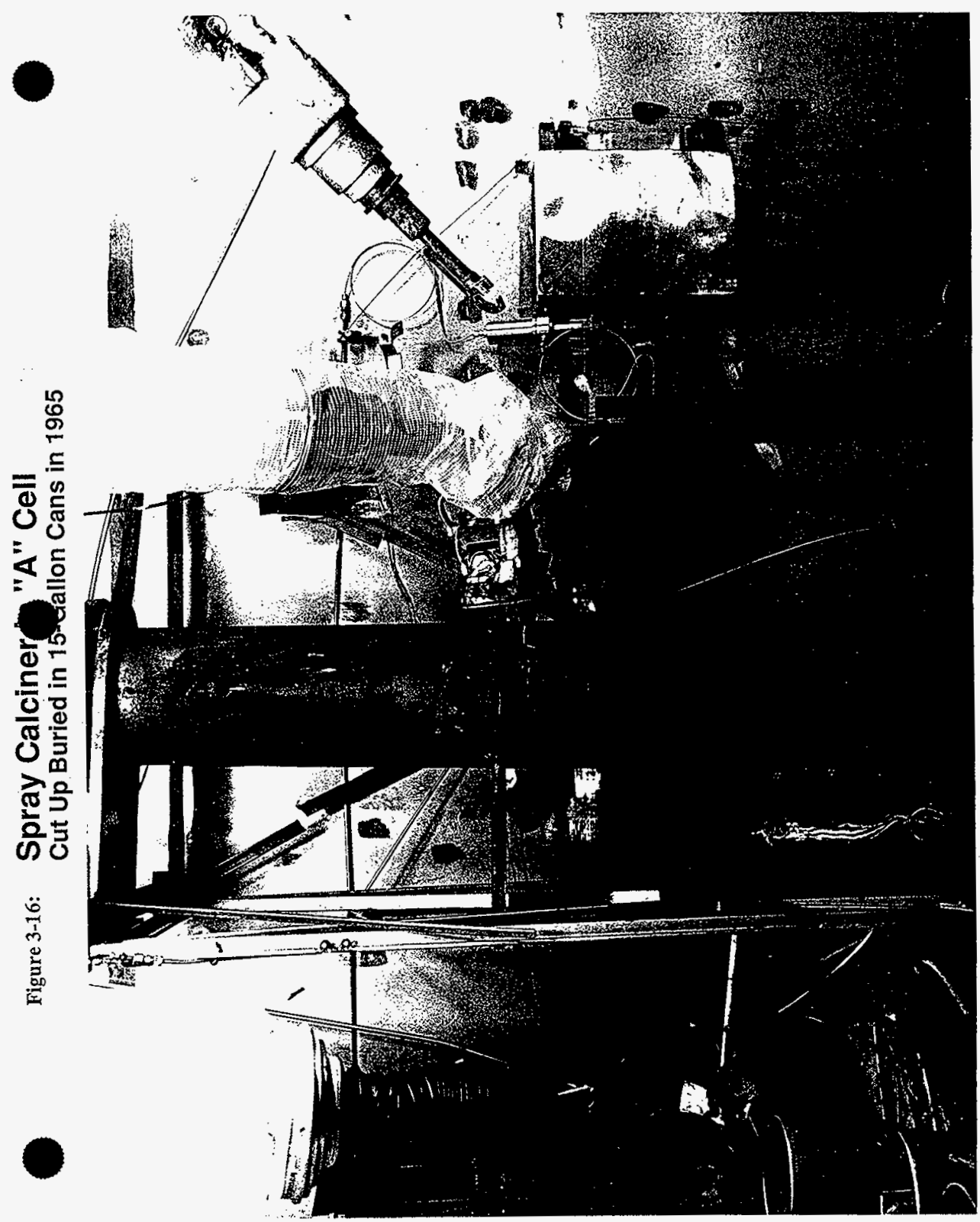


Figure 3-17: $325-A$ "A" Cell 147Pm lon Exchange (1960-1962) Equipment Sent to Burial in 1963

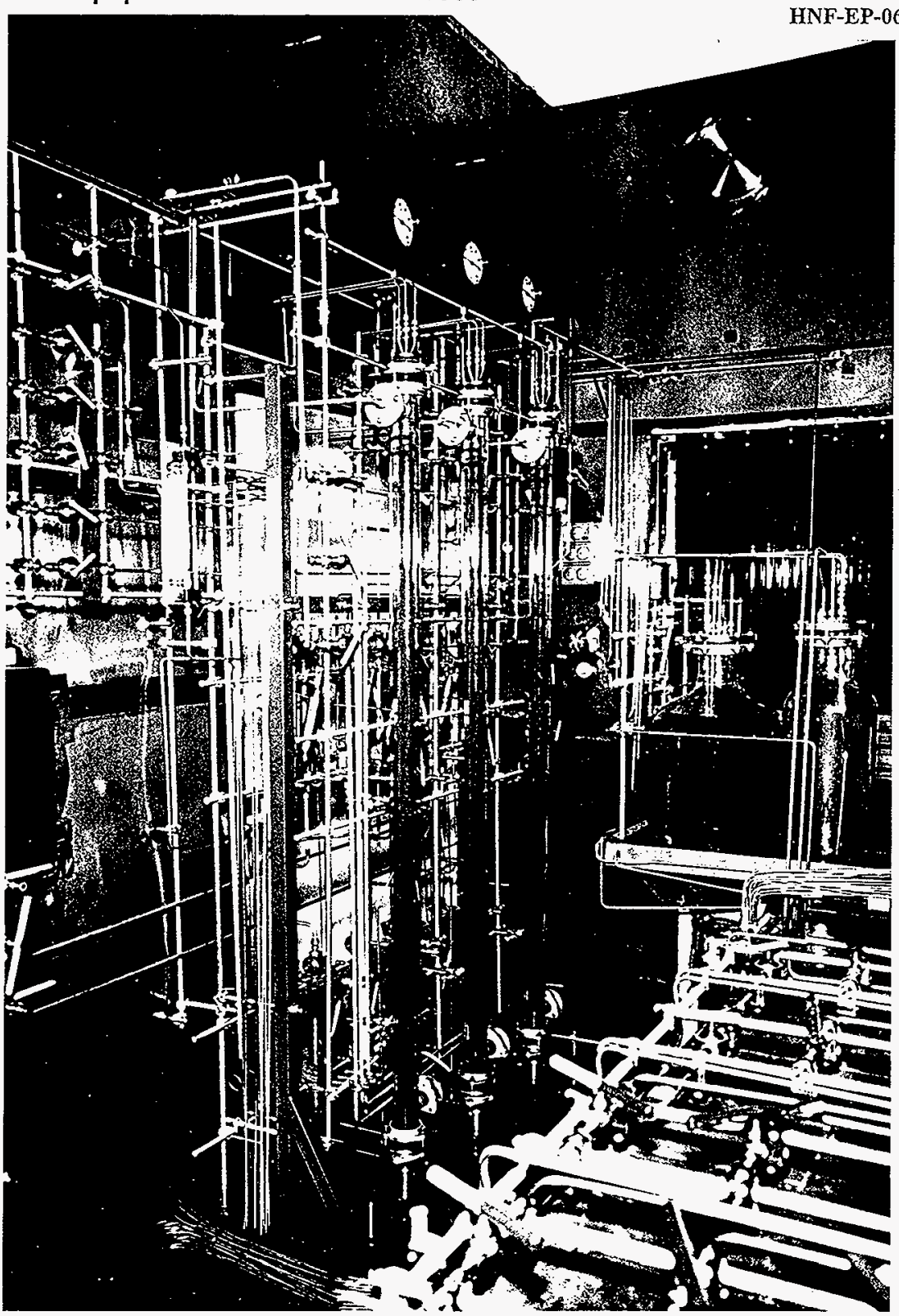




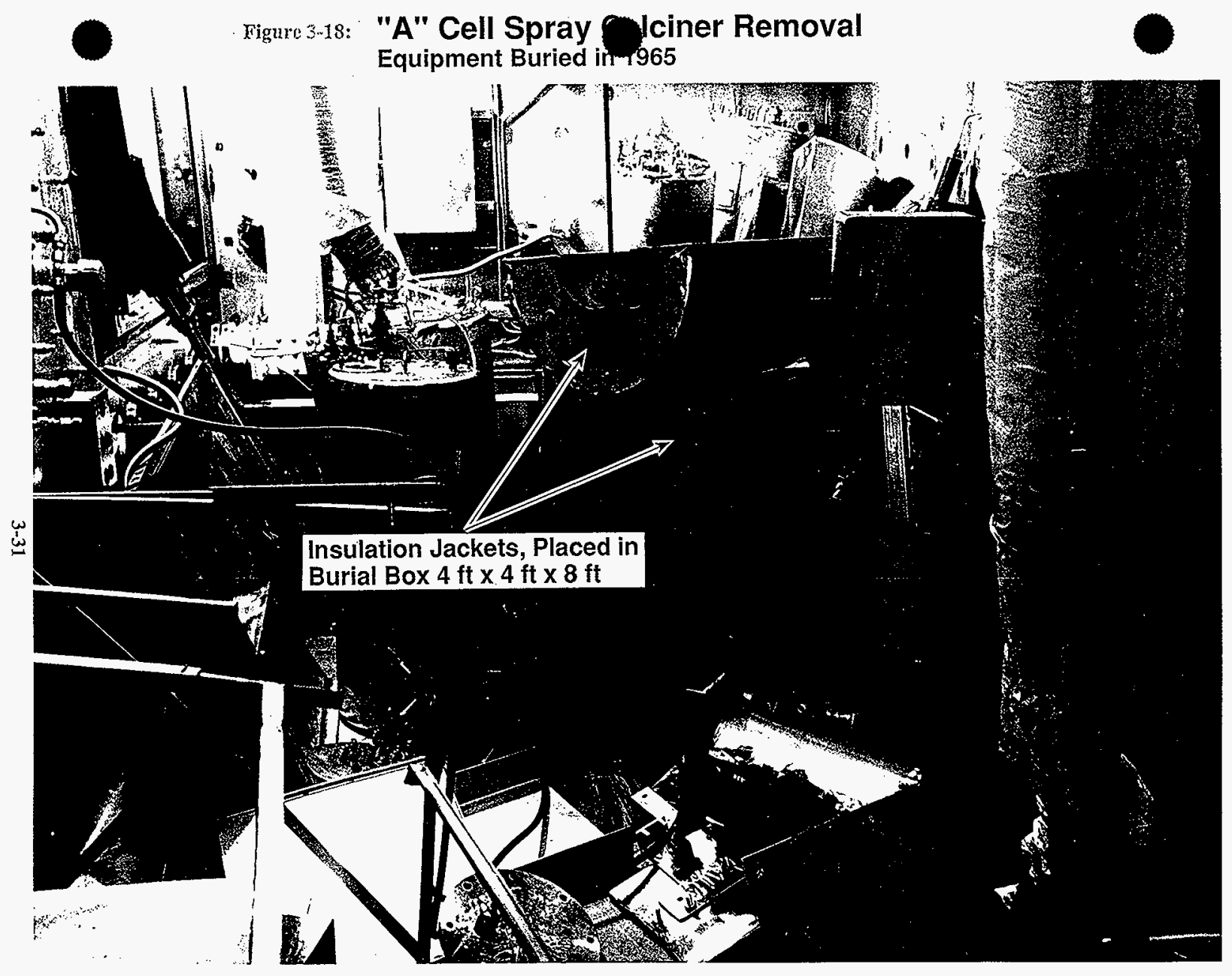


Figure 3-19: "A" Cell 147Pm Ion Exchange Pilot Plant (1960-1962) Equipment Sent to Burial 1963

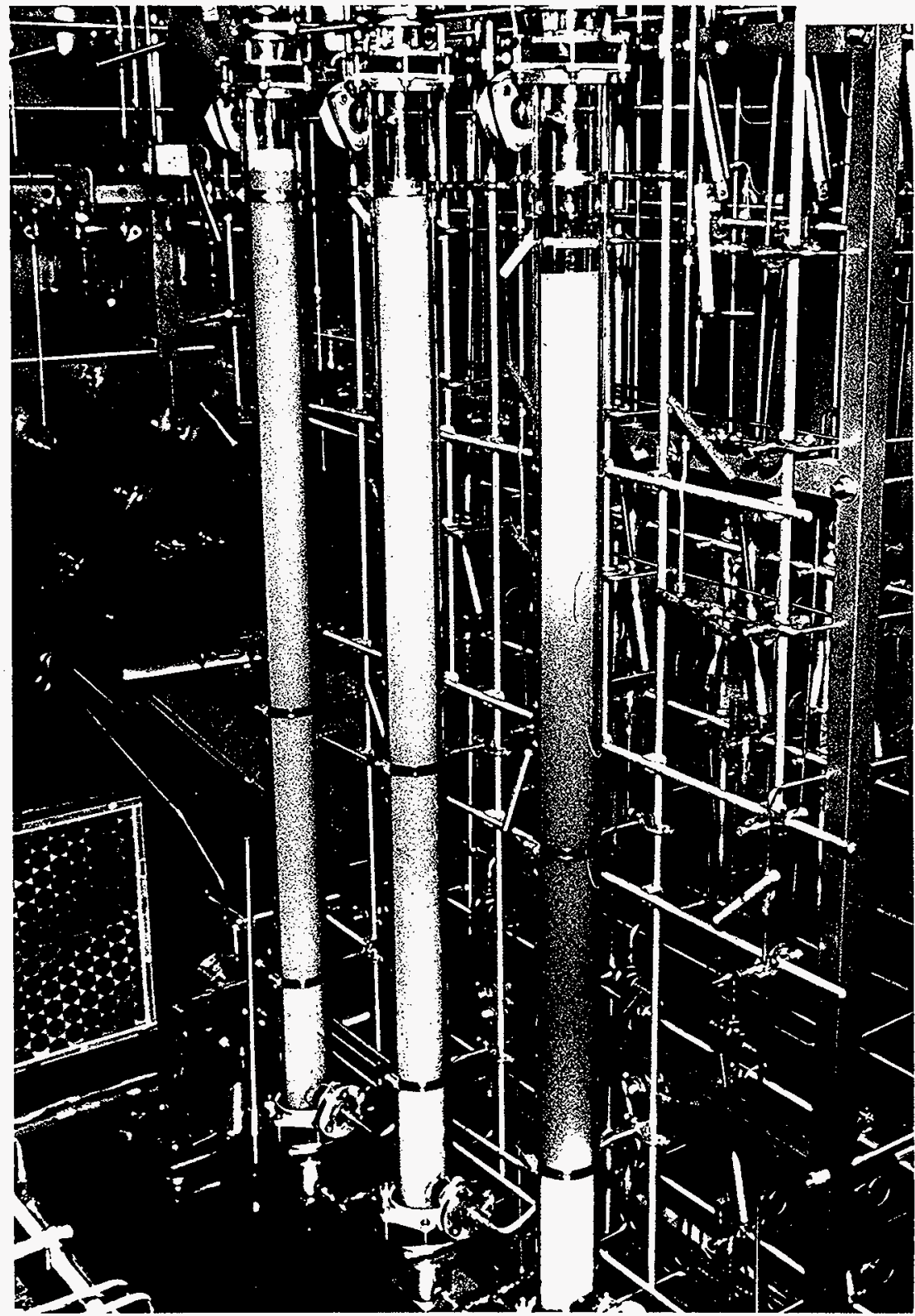


Figure 3-20: 325-A "B" Cell

Equipment Removed to Burial in 1965

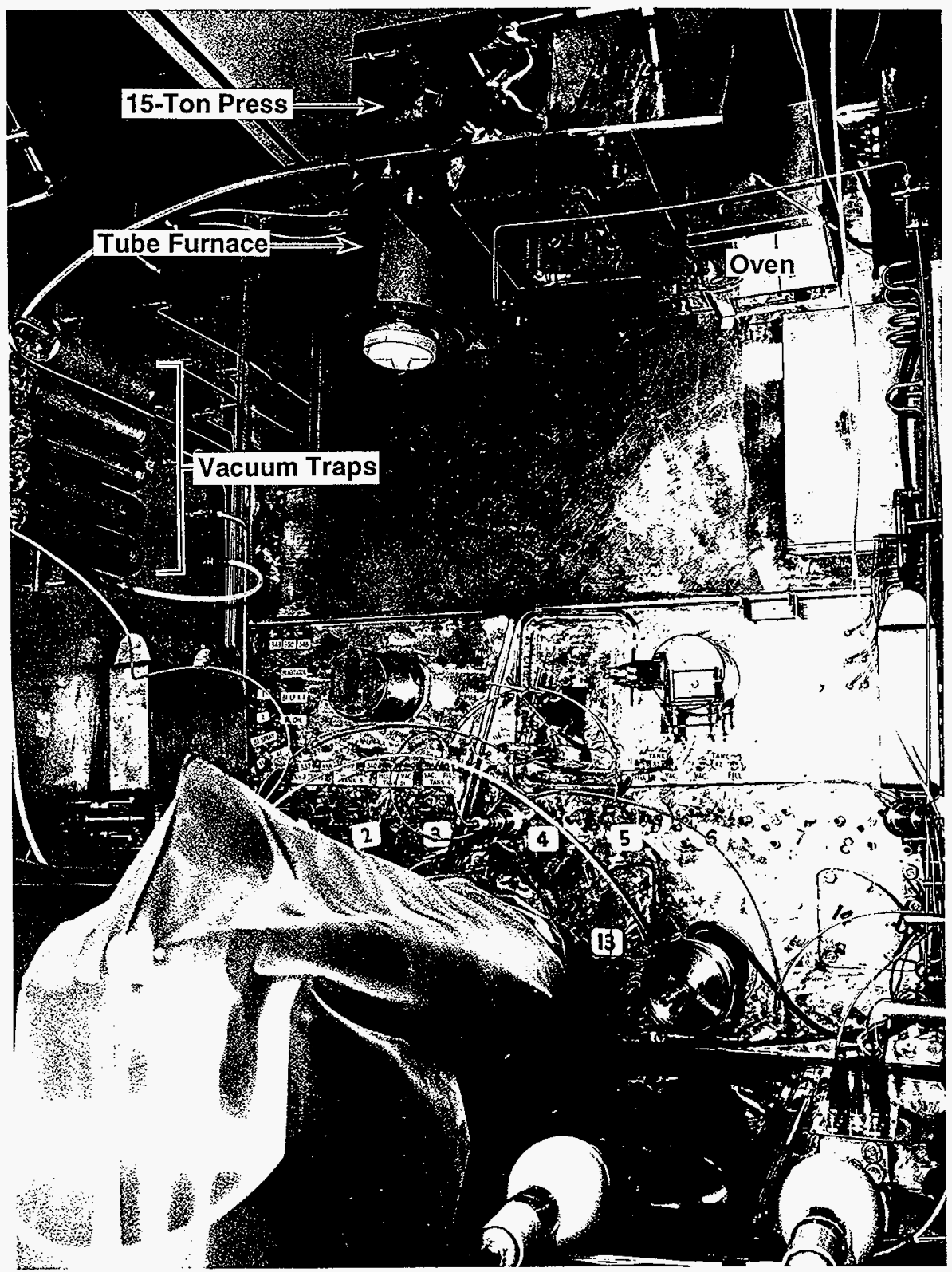


Figure 3-21: $\quad$ "C" Cell 147Pm Purification Equipment Sent to Burial 1963

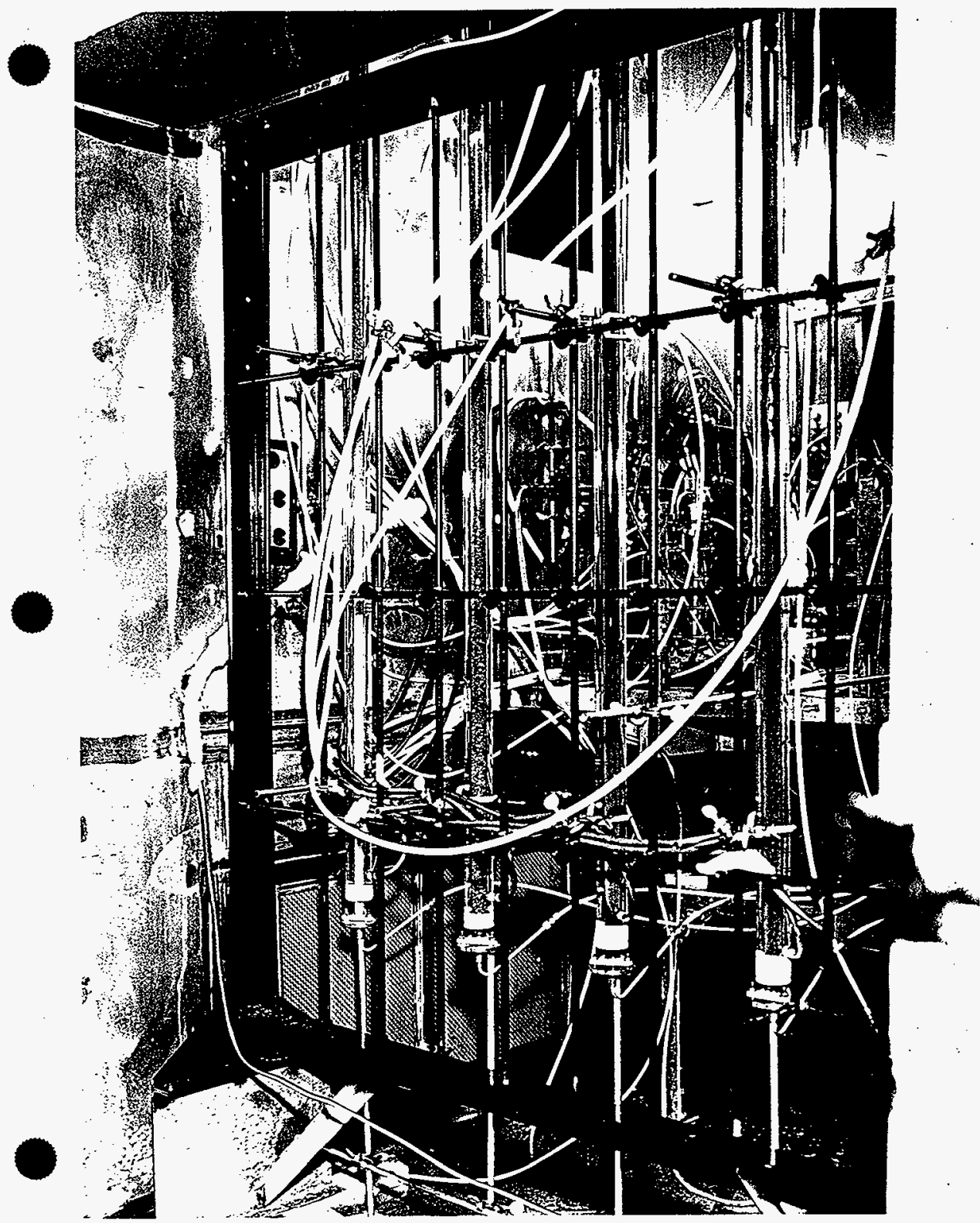


Figure 3-22: $\quad 325-A$ "C" Cell Salt Cy process (1960-1963) Equipment Sent to Burial in To64

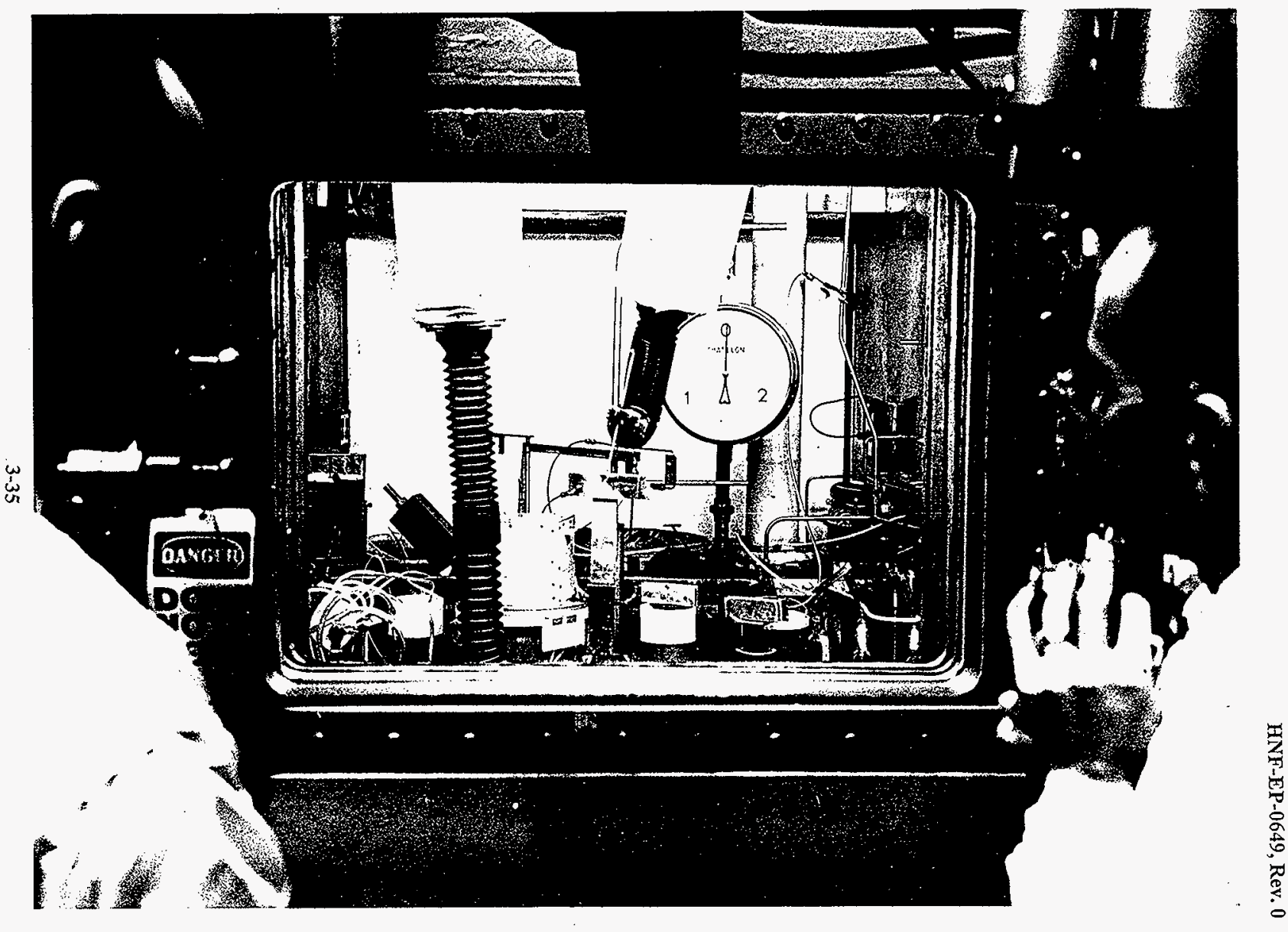


Figure 3-23: "C" Cell Salt Cycle Process Graphite Electrode Sent to Burial in 1964

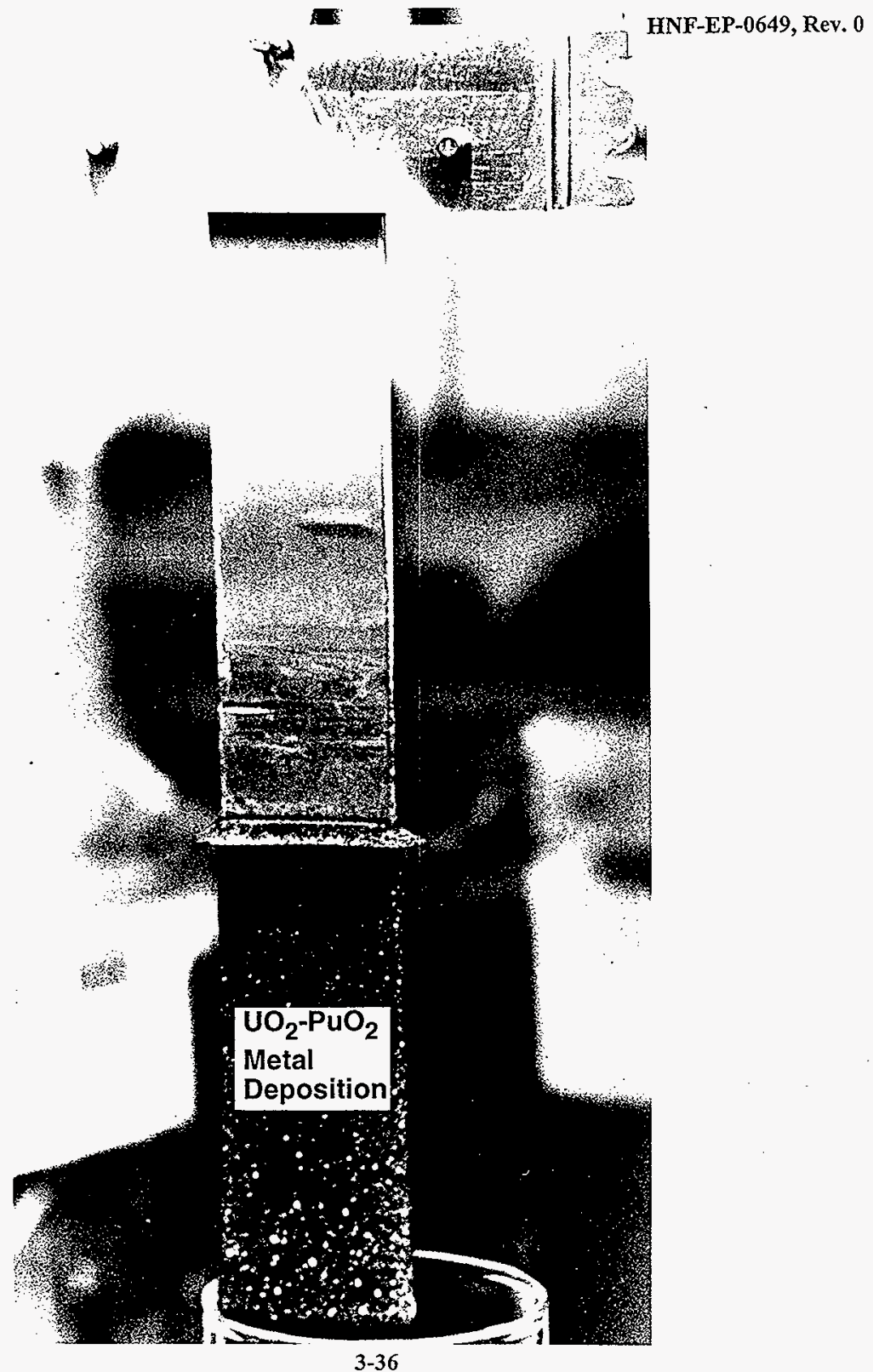


Assuming a 2 percent radionuclide content loss in the waste, the following will have transpired:

- $75,000 \mathrm{Ci}$ of $\mathrm{Sr}^{90}$ in $\mathrm{A}$-cell (1960-62) produced 1,500 $\mathrm{Ci}$ to waste that has decayed to 750 Ci today.

- $14,000,000 \mathrm{Ci}$ of $\mathrm{Pm}^{147}$ purified in A-cell (1964-1977) produced $280,000 \mathrm{Ci}$ of waste that has decayed to $100 \mathrm{Ci}$ today.

- $1 \mathrm{~kg}$ of $\mathrm{Sr}^{90}(131,000 \mathrm{Ci})$ purified in $\mathrm{A}$-cell (1964-70) produced 2,600 Ci of waste that has decayed to $1,300 \mathrm{Ci}$ today.

- $60 \mathrm{~g}$ of $\mathrm{Am}^{241}$ waste generated in $\mathrm{A}$-cell

Other R\&D projects conducted in the 325-A hot cells produced, through purification or separation, the following radionuclide volumes:

- $\quad \mathrm{Np}^{237}$ recovery in C-cell (1964-1966) - $4.3 \mathrm{~kg}$ plus 1 to $2 \mathrm{~kg}$ special dissolver test $\mathrm{Np}$ material.

- $\quad \mathrm{Pu}^{238}$ recovery in C-cell (1964-1966) - 0.3 to $0.5 \mathrm{~kg} \mathrm{Pu}{ }^{238}$.

- $\mathrm{PuO}_{2}$ production in C-cell (1960-1966) - $13.75 \mathrm{~kg} \mathrm{UO}_{2}, 2 \% \mathrm{PuO}_{2}$

The above three volumes are production, not waste, values. However, substantial quantities of radioactive materials, including TRU and alpha materials, were processed in the cells and added significantly to the waste volumes generated. One waste of particular concem is the 185 spent CWS filters that went into the 618-11 trenches. Multi-gram quantities of shortlived beta/gamma radionuclides, as well as long-lived TRU radionuclides, were entrapped in the CWS filters.

\subsubsection{History of the 327 Building From 1962 to 1968}

The 327 building is located in the middle of the 300 Area (Figure 3-24). The facility was completed and occupied in 1953. The 327 building is shown as it appears today in Figure 3-25. It was constructed to replace the termporary 111-B metallurgy building and was designated the Radiometallurgical Building. Later, the name was changed to the Postirradiation Testing (PIT) Laboratory. Since operations started in 1953, two additions and two major modifications have occurred. The floor plan, after the addition of F, G, H, and I cells, is shown in Figure 3-26. The 327 building played an important role in the metallurgical and fuel research programs conducted on the Hanford Site (Briggs 1982, Gerber 1992). 


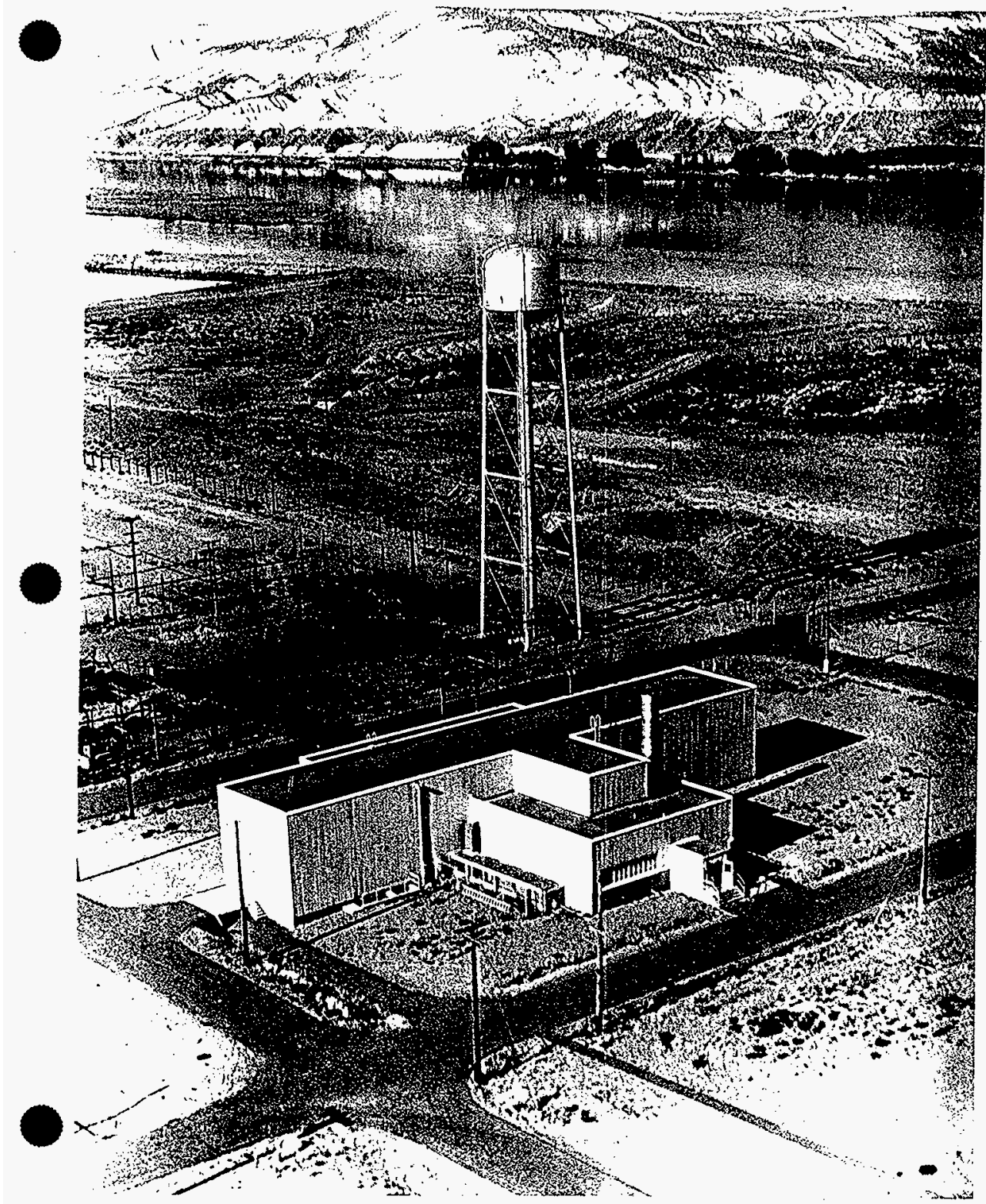


HNF-EP-0649, Rev. 0

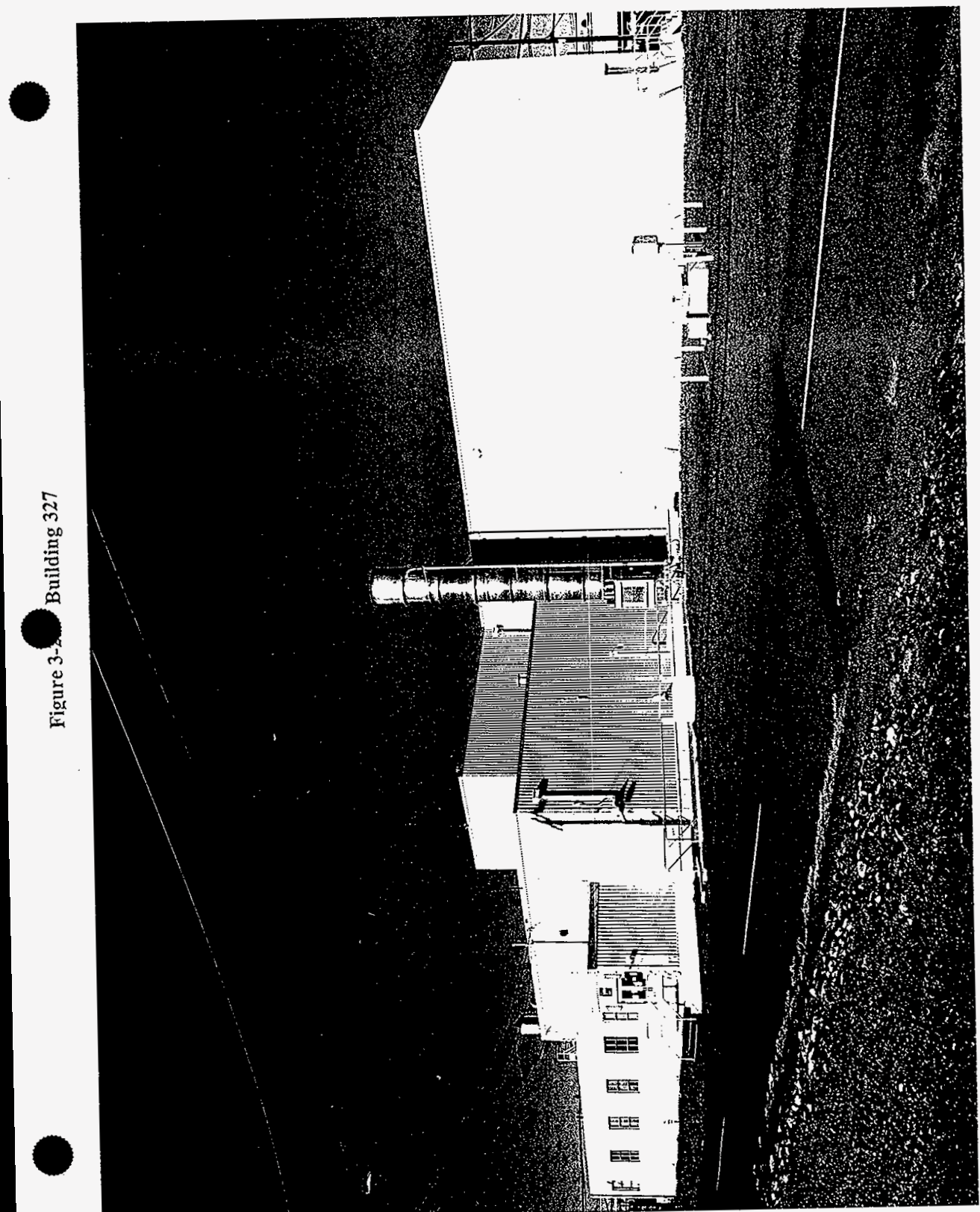


Figure 3-26: 327 Radiometallurgy Building Floor Plan

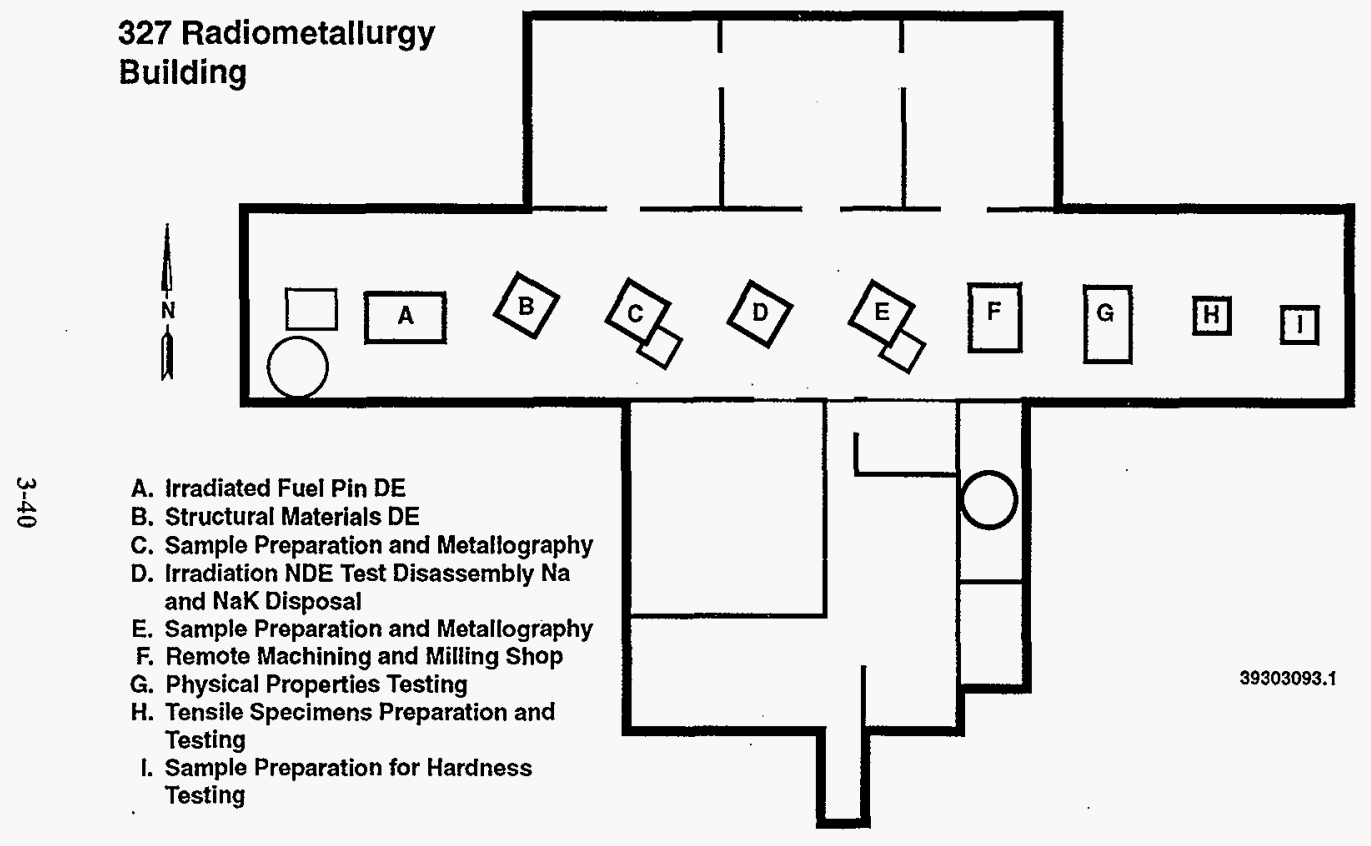


After the addition of the four cells, the facility included 10 shielded hot cells, a water-filled fuel basin, and dry sample storage facilities. Figure 3-27 shows the main canyon floor of the building looking east. The circular ports on the cells were designed to be removed to load out waste into one of several loading casks (Figure 3-28). Aluminum milk cans or buckets were used in the early 1960s as moderate and high-activity waste disposal containers. Casks, such as the one shown in Figure 3-28, replaced the milk pail and gatling-gun casks in the later 1960s. These casks could be loaded with several one gallon cans. Figure 3-29 shows the relative sizes, shapes, and characteristics of the different casks used to ship wastes from the 327 building.

The 327 building offered a wide range of capabilities including irradiated fuel pin destructive and non-destructive analyses, metallographic examinations, irradiation test assembly fabrication, and structural material testings (HEDL 1983). The laboratory is 215 feet long by 140 feet wide by 32 feet high. The main operating canyon had 10 alpha qualified steel shielded cells. A directory of the cells and the operations conducted in each cell is given in Table 3-4. Adjacent auxiliary areas include a photography laboratory, machine shop, manipulator repair area, a semi-radioactive metallography facility, and the storage and loading area for casks using bridge cranes (Figure 3-30). A typical isometric view of a 327 hot cell unit is given in Figure 3-31. The basement area contained storage space and stored equipment, hot cell exhaust systems, RLWS lines, air conditioning, utility, and power services.

The 327 building was used to perform physical and metaliurgical examinations of irradiated nuclear materials. These included nuclear fuels such as natural or enriched uranium in the metal or the oxide (dioxide) form, plutonium in the metal alloy or oxide form mixed with uranium, and thorium oxide (dioxide) mixed with the oxides of uranium or plutonium. Fuel cladding materials including aluminum, stainless steel, and zirconium alloys were examined as were reactor structural materials, including graphite, aluminum, stainless or mild steel, and zirconium alloys. Examination specimens could range from $3 / 8$ inch diameter spheres to fuel element assemblies which were eight feet long and more than three inches in diameter. The 327 building activities conducted during the 1950s and 1960s are summarized in Table 3-5.

Hot cell operations in the 327 building differed from those in 325-A. The materials testing campaigns involved examination of different fuels and materials not stripping hot cells of equipment and refurbishing with new equipment as was done in 325-A hot cells. Failed equipment was removed and new equipment was installed infrequently. The 327 wastes were metal and fuel grindings; fuel pieces; specimen-cleaning solutions on wipes; small laboratory equipment; hardware used in the metallographic preparations; and residues from sampling, storing, mounting, and examination of specimens. A survey of four different one-gallon cans of 327 waste from typical fuel sampling and testing operations produced the results listed in Table 3-6. The survey was carried out in the 1980s. 327 building operations had not changed much from the 1960s and this waste is expected to be characteristic of the 327 hot cell wastes that went to the 618-11 burial ground (Greenhalgh 1986). 


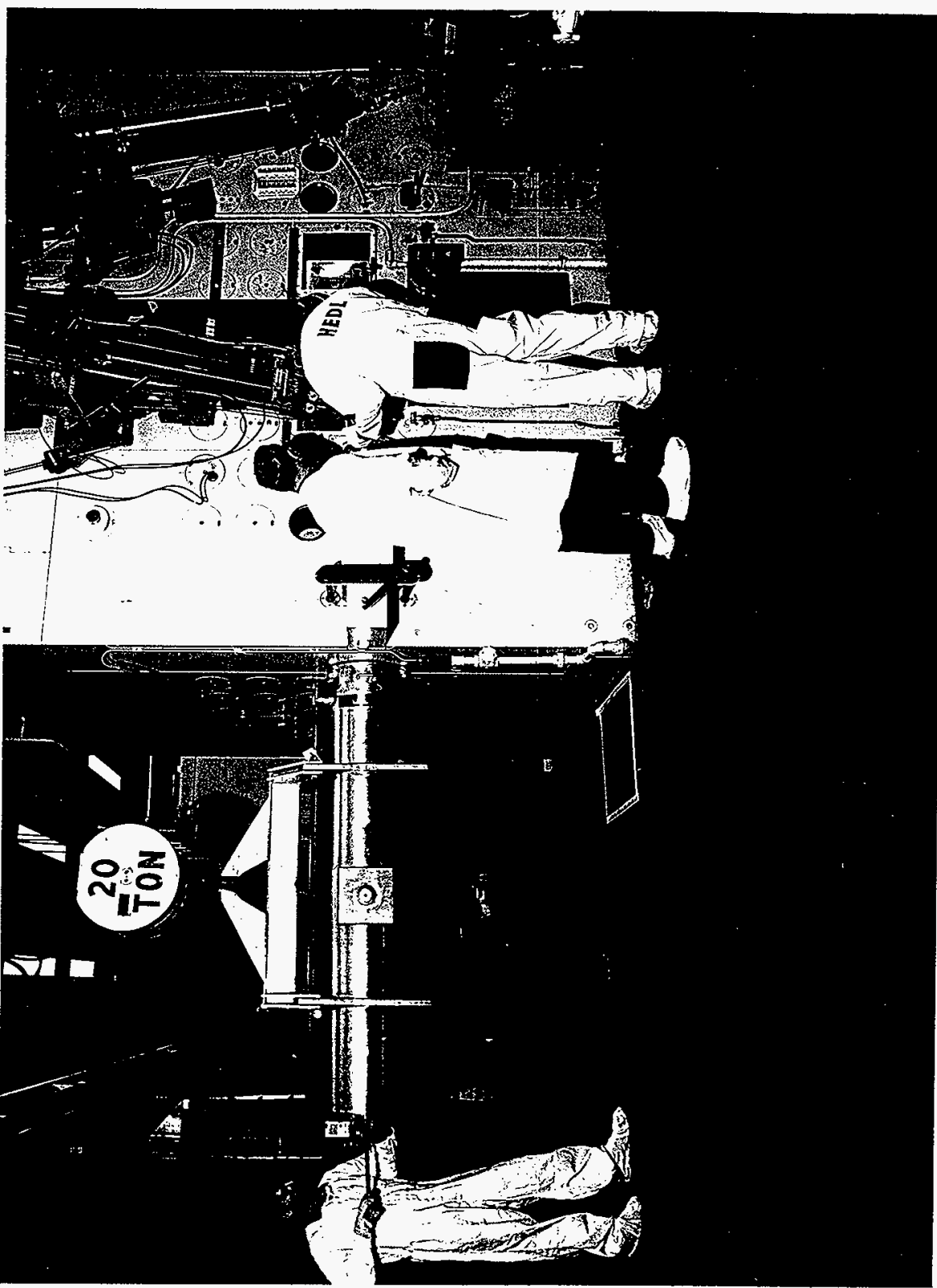


Figure 3-29: 327 Building Cask Collection

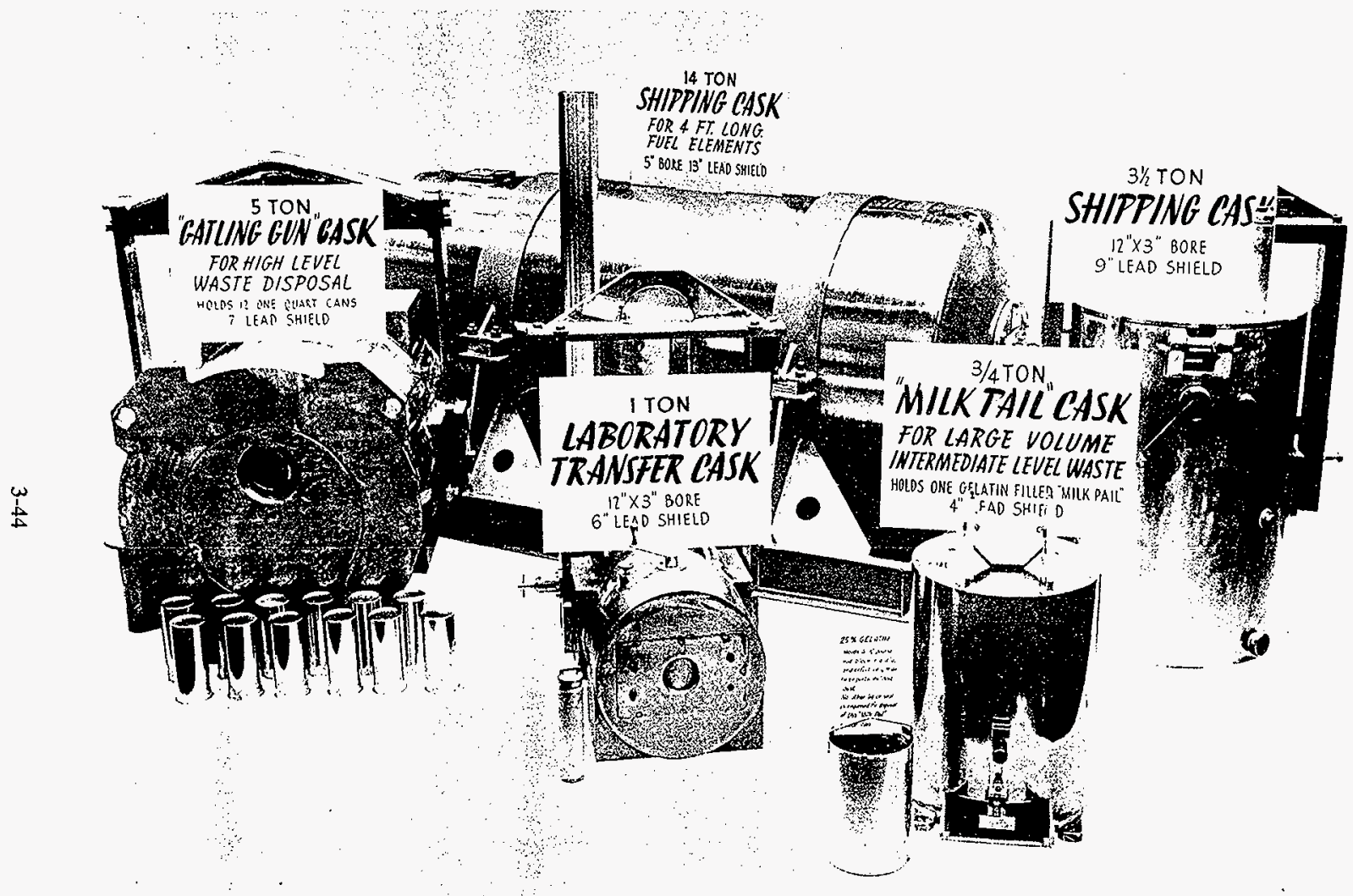




\section{Table 3-4: Directory of 327 Building Cells}

(Autumn 1962)

\section{Title Shielding}

\begin{tabular}{|c|c|c|c|}
\hline A Cell & Examination & $\begin{array}{l}18^{\prime \prime} \text { Cast Iron } \\
\text { (Meehanite) }\end{array}$ & $\begin{array}{l}\text { Initial examination and } \\
\text { photography. Length, diameter and } \\
\text { wrap measurements. Sample } \\
\text { cutting. }\end{array}$ \\
\hline B Cell & Chemistry & 15 " Cast Iron & $\begin{array}{l}\text { Sample dissolution for burn-up } \\
\text { analysis. Chemical decladding. } \\
\text { Fission product gas collection and } \\
\text { measurement. Auxiliary sample } \\
\text { cutting. }\end{array}$ \\
\hline C Cell & Metallography & 10-1/2" Cast Iron & $\begin{array}{l}\text { Sample grinding, polishing and } \\
\text { etching. Metallography. } \\
\text { Replication for electro microscopy. }\end{array}$ \\
\hline D Cell & $\begin{array}{l}\text { Materials } \\
\text { Testing }\end{array}$ & 10-1/2" Cast Iron & $\begin{array}{l}\text { Micro hardness testing. Micro } \\
\text { sampling. Pulse annealing. } \\
\text { Scintillation scanning. }\end{array}$ \\
\hline E Cell & Utility Cell & 10-1/2" Cast Iron & $\begin{array}{l}\text { Hardness testing. Annealing. } \\
\text { Equipment mockup. }\end{array}$ \\
\hline F Cell & $\begin{array}{l}\text { High Level } \\
\text { Utility }\end{array}$ & 18 " Cast Iron & $\begin{array}{l}\text { Sample forming, mechanical } \\
\text { decladding, and capsule opening. }\end{array}$ \\
\hline G Cell & $\begin{array}{l}\text { Physical \& } \\
\text { Mechanical } \\
\text { Testing }\end{array}$ & 10-1/2" Cast Iron & $\begin{array}{l}\text { Tensile, fatigue, and impact testing. } \\
\text { Dilatometry and electrical } \\
\text { resistivity. Annealing. }\end{array}$ \\
\hline H Cell & $\begin{array}{l}\text { High } \\
\text { Temperature } \\
\text { Tensile Testing }\end{array}$ & 10-1/2" Cast Iron & $\begin{array}{l}\text { Tensile testing at room and high } \\
\text { temperatures }\left(1000^{\circ} \mathrm{C}\right) \text {. } \\
\text { Micro-photography. }\end{array}$ \\
\hline \multirow[t]{3}{*}{ I Cell } & Tensile Testing & 10-1/2" Cast Iron & $\begin{array}{l}\text { Tensile and compression testing at } \\
\text { room temperature. }\end{array}$ \\
\hline & Density Cell & 8" Lead & Density determination. \\
\hline & X-Ray Cell & 6" Lead & X-Ray diffraction studies. \\
\hline
\end{tabular}

Operation

Initial examination and photography. Length, diameter and wrap measurements. Sample Sample dissolution for burn-up analysis. Chemical decladding. Fussion product gas collection and measurement. Auxiliary sample etching. Metallography. Micro hardness testing. Micro sampling. Pulse annealing. Hardness testing. Annealing. Sample forming, mechanical ecting, and capsule opening. Tensile, fatigue, and impact testing. Dilatometry and electrical Tensile testing at room and high temperatures $\left(1000^{\circ} \mathrm{C}\right)$. room temperature. $\mathrm{X}$-Ray diffraction studies. 


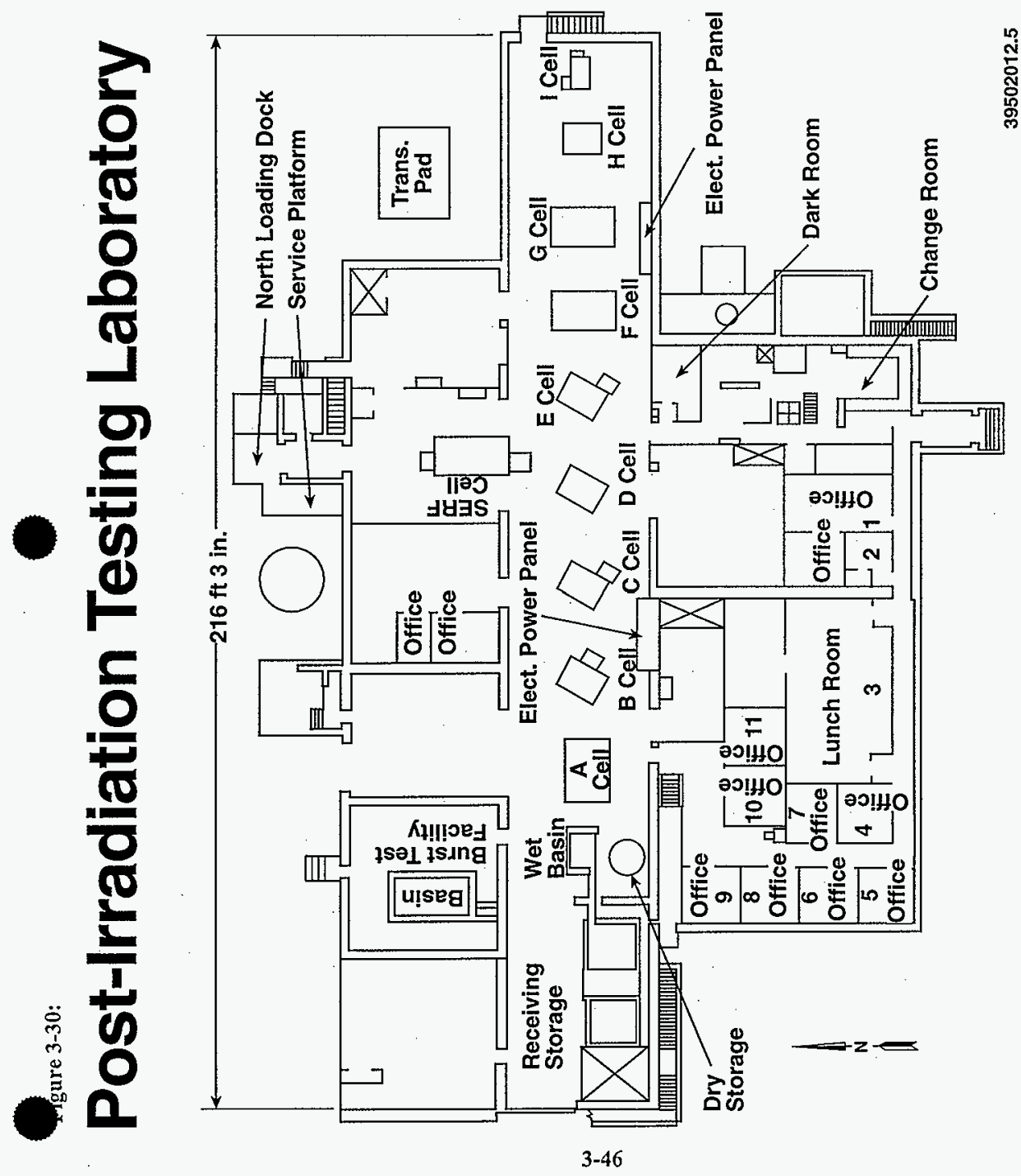


HNF-EP-0649, Rev. 0

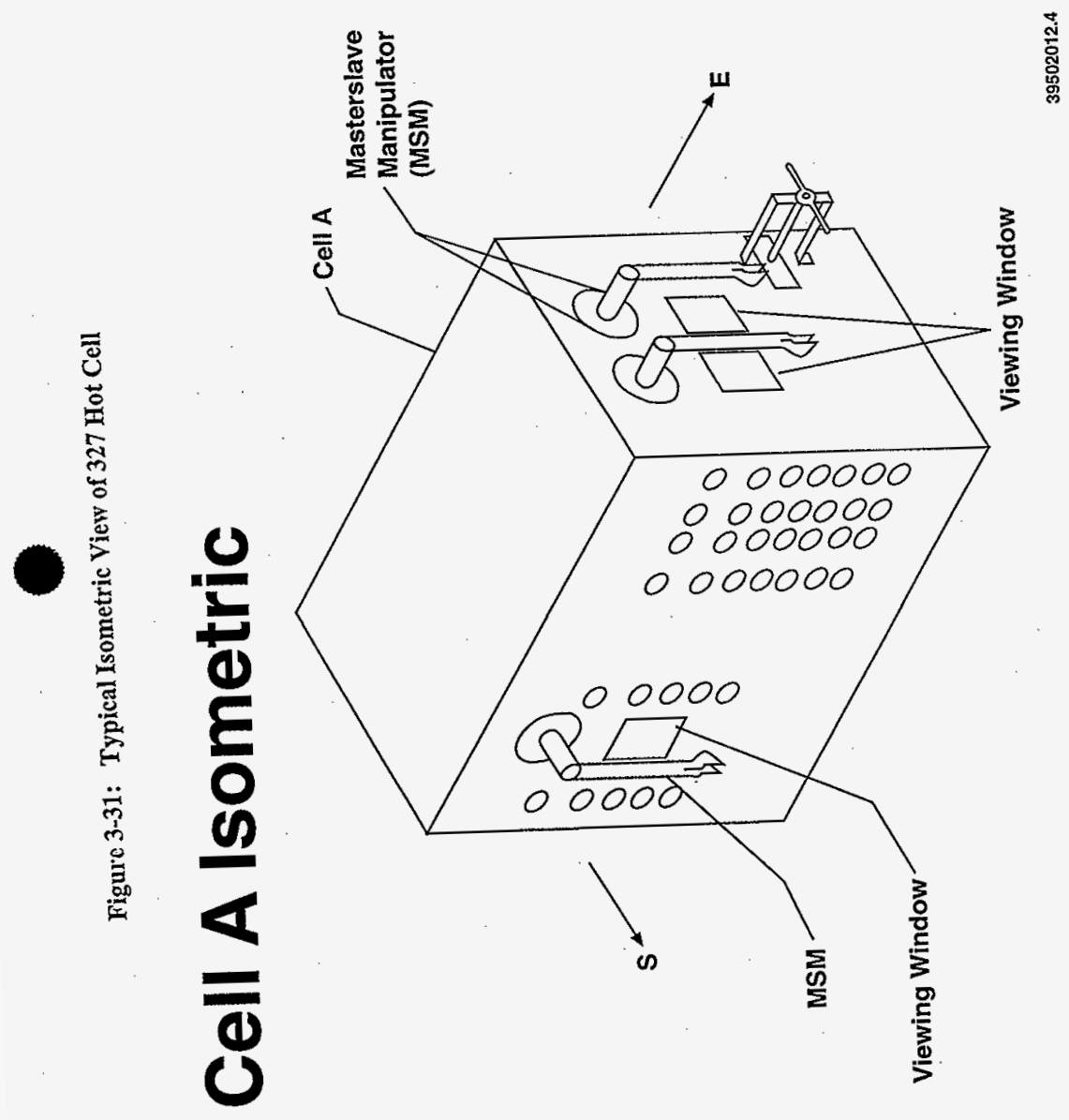




\section{Table 3-5: 327 Building History}

1953-1970 Provide surveillance and rupture/failure analysis for fuel elements and materials for the Hanford Production Reactors.

1958

Evolution from aluminum to zirconium clad metal fuels, zirconium 11 environment with $\mathrm{NaK}$, Ni plating of cladding, etc.

1958-1968 Provide surveillance and rupture/failure analysis for fuel elements and materials for the Plutonium Recycle Test Reactor.

1959-1965 Examination $\mathrm{PuO}_{2}-\mathrm{UO}_{2}$ fuels and the introduction of higher enrichment fuels, use of stainless steel cladding, etc..

1960 Facility was expanded to eleven Hot cells to provide additional examination capabilities.

1960-1988 Provide surveillance and rupture/failure analysis for fuel elements and materials for $\mathrm{N}$-Reactor. Pressure tube safety enhancement project.

1961 Plutonium impregnated graphite, GEH series prototypic fuel pins, etc..

1962 PRTR pressure tube burst testing, examination of prototypic fuel materials, e.g., magnesium oxide and $\mathrm{PuO}_{2}$, etc.

1963 Waste tanks sludge examination, SNC cermet fuel examination, etc.

1964 Aluminum/aluminum lithium examination, waste glass concentrate examination, British fuel and material examination, etc..

1965 First series of ruptured N-Reactor fuel element examinations, thorium oxide examinations, etc..

1965-1972 Examination of fuels and materials for NASA.

1967

Heat source examinations, e.g., cesium chloride, promethium oxide, strontium. 
HNF-EP-0649, Rev. 0

\section{Table 3-6: The Representative Contents of Simulated 327 Remote Handled Transuranic Waste}

\section{Quantity}

Can No. 1
$\mathrm{CanNo} .2$

25

10

10

5

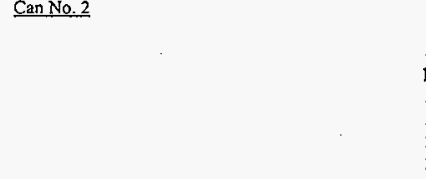

Can_No. 3
180 grit grinding discs 240 grit grinding dises 400 grit grinding discs 600 grit grinding dises Pellon polishing dises Micro-cloth polishing discs Aluminum brads

Cotton sample swabs Nylon sample grinding caps \#8-1/2 rubber stoppers \#1-1/4 plasic pipe caps

13 Dram plastic vials and caps Kotex napkins

Mod. "G" manipulator boot 4" ice cream carton \#1-3/8 rubber tube caps $1 / 2$ " rubber tube caps $\# 1 / 2 \times 3$ snap cap vials Nylon sample grinding caps Kotex napkins WypAll paper towels

\#1-1/4 plastic pipe caps $1-1 / 3 \times 2-1 / 8$ plastic vials and caps $1 / 2 \times 1$ tapered corks Nylon sample grinding caps \#5-1/2 rubber stopper

$7 / 8 \times 2$ plastic vials and caps

\#1/4 rubber tube caps \#1/4 threaded steel pipe plugs $2 \times 4$ glass dish Ink Marker

1" nylon paint brush \#105 rigid tubing cutter \#10-099 Stanley utility knife

Kotex napkins WypAll paper towels $12 \times 14$ plastic bag

Kotex napkins

$23 / 4 \times 3$ aluminum weight (round)

$11 / 2 \quad 1-1 / 8 \times 3$ aluminum block.

$7 / 8 \times 1 \times 21 \%$ SS block

$1 / 4 \times 1 \times 1 \times 7$ aluminum angle metal

Krylon spray paoint can (punctured)

$24 \times 24$ cloth rag

$2 \times 4$ plastic bottle

$1 / 2 \times 2 \times 3$ aluminum block

rubber canner's gloves

WypAll paper towels

Contents and Description 
Figure 3-32 is a typical fuel sample flow chart for the 327 building main floor. A test fuel element entering the 327 building generally arrived in a large, lead-filled stainless steel cask and was loaded either into a water-filled storage basin or directly into one of the cells. Examination steps that may then be performed include photography; length, diameter, and warp measurement; and metallography. In this operation, metal samples are cut with a silicon carbide saw and ground, polished, etched, and photographed at high magnifications. 
Figure 3-32: Radiometallurgy Flow-Chart

\section{Radio - Metallurgy Flow Chart}

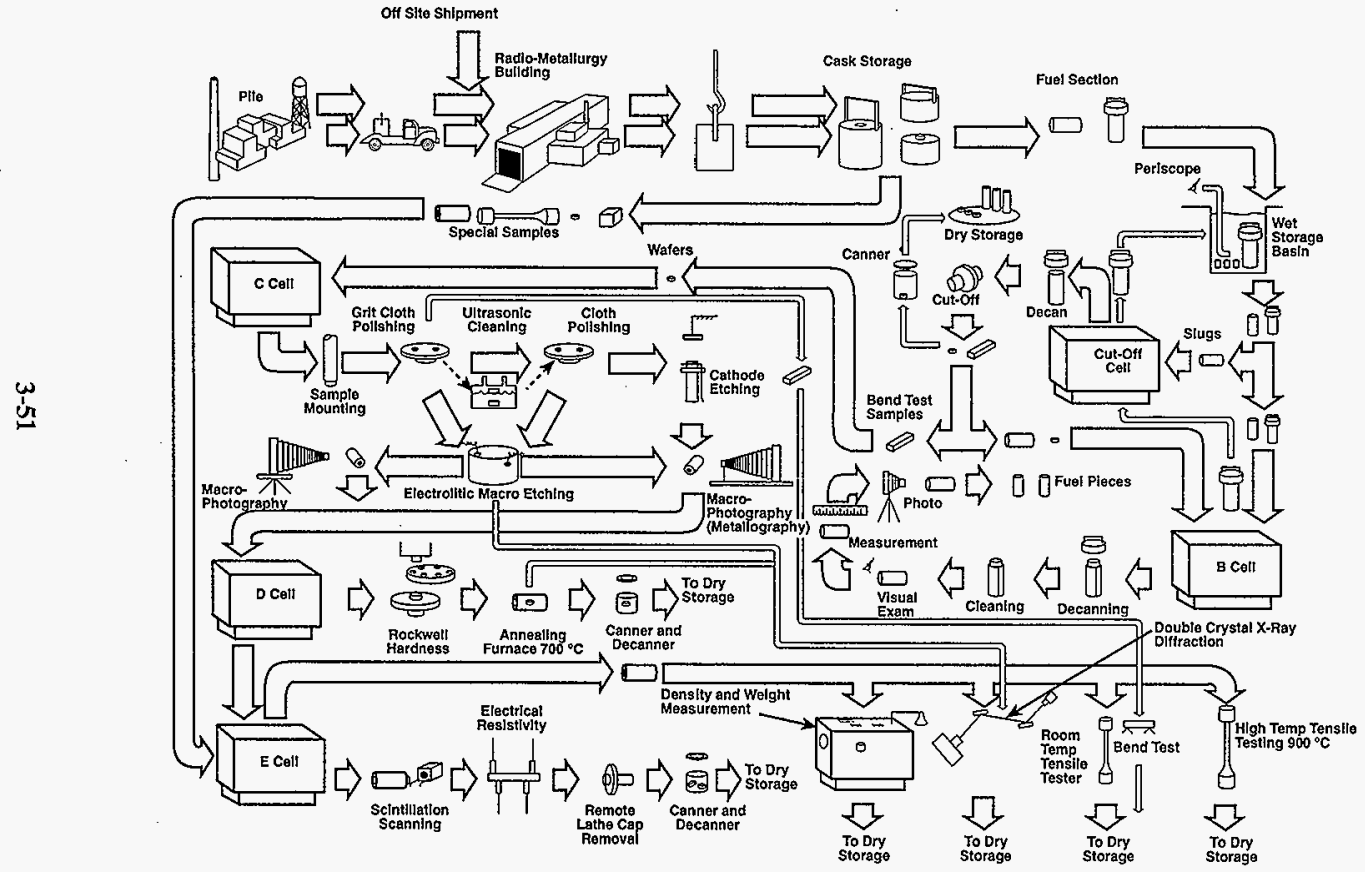


Numerous additional examinations were carried out, including hardness testing, tensile testing at room and elevated temperatures, dilatometry, density, annealing studies, and X-ray diffraction studies. Fission product gas was collected and measured from experimental ceramic fuel elements. Samples from various elements were dissolved for chemical analysis to determine the amount of irradiation each sample had received.

The 327 facility was used to examine, test, and analyze irradiated fuel specimens. Work activities included the following:

- Visual and photographic examinations

- Density and balance point measurements

- Tests on irradiated capsule assemblies and disassemblies

- Remote sample forming

- Irradiated fuel pin modification

- Assembly of irradiated fuel components

- Welding of fuel components and other hardware

- Component inspection/qualification

- Fission gas collection

- Fuel burn-up examinations

- Microstructural studies

- Metallography

- Ceramography

- Microprobe sample preparations

- Replication

- Fuel pin/capsule assembly

- Fuel cladding transient tests

- Post test recovery and examination work.

These operations produced much of the waste listed in Table 3-6, plus spent and failed equipment items. Most of this waste was contaminated with irradiated fuel specimens and is therefore of moderate or high-activity. The moderate and high-activity wastes disposed to the 618-11 burial ground were shipped from the 327 building using either the gatling-gun cask or the milk-pail cask (Gift HW-76192). The data sheets for 327 building casks used for 618-11 disposal are shown in Figures 3-33 and 3-34. A copy of the milk pail cask loading procedure is given in Appendix D. 
Figure 3-33: Radiometallurgy Gatling Gun Cask

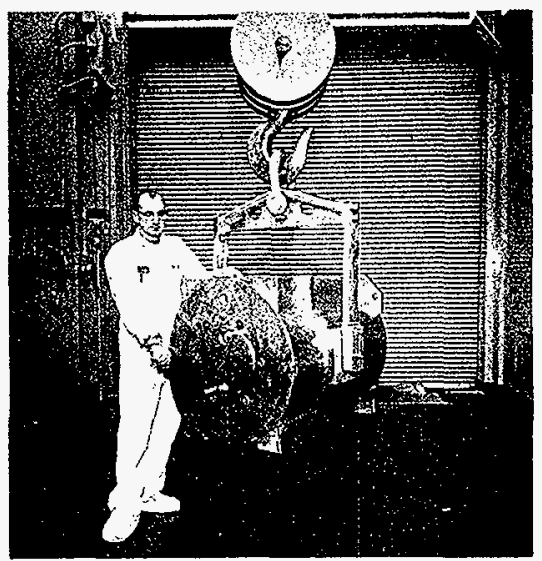

Radioactive Weste Disposal. Cask

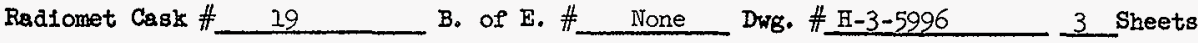

Commonly Known As: Gatling gun cask

Dimensions: $30^{\prime \prime}$ O.D. By: $37^{\text {tt }}$ long

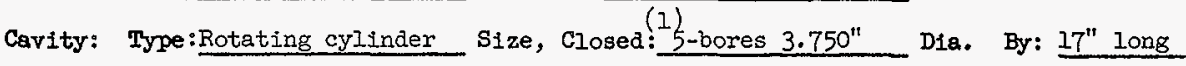

Cavity: Type:Rotating cylinder Size, Closed:L-bores $3.750^{\prime \prime}$ Dia. By: 17" 1ong

Closure (s): Loading plug 3-5/8" $\times 10^{\prime \prime}$; end plug 10" $\times 14^{\prime \prime}$; both flenged

Approximate Weight of Removable Plug(s): 25 and 200 Ibs.

Alternste Plug Length: None

Shell: $30^{\prime \prime}$ Sch. 30 stainless steelpipe Cavity Liner: Stainless steel w/stainless stee: Shielaing: $\quad 7^{\prime \prime}$ Po Total Welght: 7400 lbs. cylinder

Yoke: Attached - positionable

\begin{tabular}{|c|c|c|c|c|}
\hline \multirow[t]{2}{*}{ Normal Positions: } & \multirow{2}{*}{$\begin{array}{l}\text { Loading: } \\
\text { Hauling: }\end{array}$} & Horizontal & \multirow{2}{*}{$\begin{array}{l}\text { Unloading: } \\
\text { Storlng: }\end{array}$} & Vertical* \\
\hline & & Vertical* & & Hortzontal \\
\hline
\end{tabular}

* Special trailer required.

(1) Sixth bore plugged for safety factor. 
Figure 3-34: Radiometallurgy Milk Pail Cask

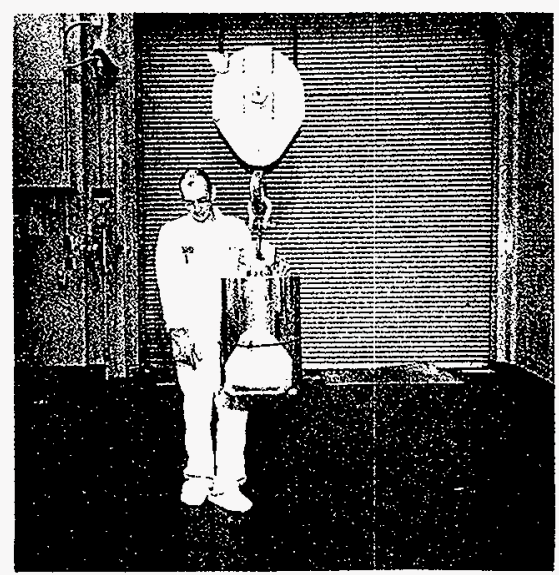

Radioactive Waste Disposal Cask

Radiomet Cask \# 18 and 23 B. of $\mathrm{E}$. \# None Dwg. \# $\mathrm{H}-3-13077$ Sheets Commonly Known As: Milk pail cask

Dimensions: $16^{\prime \prime}$ O.D. By: 26-1/2" high, including hitch

Cavity: Type: Inverted well Size, Closed: $7.264^{\prime \prime}$ Dia. By: $13-1 / 8^{\prime \prime}$ hig closure(s): 2. 2" thick slide at bottom, 3/4" plug at top Approximate Weight of Removable Plug(s): Alternate Plug Length: -

Shell: $16^{\prime \prime}$ Sch. 20 stainless steel pipeCavity Liner: Stainless steel Shielding: $4^{n} \mathrm{Fb}$ Total Weight: 1200 1bs.

Yoke: Attached swing Normal Positions: Loading: Vertical* Unloading: Vertical* Houling: Vertical Storing: Vertical

* Bottom loading and unloading No. 18 and No. 23 have identical specifications. 
Smith (1965) provided nuclear safety specifications for controlling plutonium amounts in the 327 building dry storage. The specification indicated the amount of plutonium that could have potentially been processed through the 327 building. This waste characteristic will be discussed in detail in Section 3.2.

In addition to the mixed fission products work at the 325-A hot cells, the 327 building administration had a concern about the higher enrichment $\mathrm{Pu}^{240}$ fuels. Fuel specimens with up to 22 percent $\mathrm{Pu}^{240}$ were tested for the Clinch River Breeder Reactor (CRBR) and FFTF programs, although the standard was approximately 11 to 12 percent. This markedly increased radiation exposure rates. These higher $\mathrm{Pu}^{240}$ enrichment values from the 327 building coupled with the $\mathrm{Pu}^{238}$ and $\mathrm{Np}^{237}$ values from the $325-\mathrm{A}$ facility will be used to determine the estimated dose equivalent (EDE) onsite and offsite for remediation activities.

\subsection{WASTES GENERATED}

Individual waste shipment records for all wastes shipped to the 618-11 burial ground were maintained onsite until 1988 and SNM records were kept onsite until 1992. Unfortunately, both sets of records were destroyed. The loss of these two sets of records have made this work difficult and caused uncertainty about some of the information. The SNM records contained fissile assay data that are partly recorded on the SWITS database. Despite the loss of this primary records data, some burial records data were maintained and delivered to the authors of this document. PNL and WHC radiation survey records are available from record storage. Some facility shipping records have also been obtained. In addition, information has been obtained from old photographs, scientific surveys, published documents, letters, memos, and logbook data. These sources have been brought together in this document to yield characterization data of the wastes disposed of at the 618-11 burial ground. Most of the records data discovered has been tabulated and appears in the appendix or in tables throughout the text. The characterization of the waste is considered as complete as possible without the official individual waste shipment records and the corresponding fissile (plutonium) contents. This data is also intended to support development of accident scenarios, EDE release calculations, site sampling and investigation needs, safety assessment development, and other site remediation activities

Segregation of TRU wastes from non-TRU wastes was not conducted during the operational time frame of the 618-11 burial ground. Even though many understood the land use withdrawal ramifications of burying long-lived radionuclides with other radioactive wastes (Corley 1967), segregation of TRU wastes from non-TRU wastes was not mandated by the AEC until 1970. Even after mandating, segregation of TRU wastes from non-TRU wastes took several years to implement in some facilities (Craddock 1975). It should also be noted that entire disposed waste volumes became TRU through non-segregation. Craddock (1975) reports that the TRU volumes from the postirradiation facilities ( 327 and 324 buildings) could have been reduced by $90 \%$ if they had been segregated. 
Estimated plutonium values of waste disposed to the three trenches are discussed in Section 3.6. Calculations indicate that the trenches are TRU and are significantly above the TRU limit of $100 \mathrm{nCi} / \mathrm{g}$ with an estimated $0.043 \mathrm{~g} /$ feet $^{3}$ plutonium density in the disposed trench waste. Characterization information and references indicate that the drum storage units and caissons are also TRU. Corley (1967) indicates that significant amounts of $\mathrm{Pu}^{239}$ have been disposed of to the $618-11$ burial ground caissons.

The 618-10 and 618-11 burial ground shipping records that are available are given in Appendix E. The records are summarized in Table 3-7. According to this information approximately $4420 \mathrm{~m}^{3}\left(156,201\right.$ feet $\left.^{3}\right)$ were disposed to the three $618-11$ trenches, $50 \mathrm{~m}^{3}$ $\left(1,766 \mathrm{feet}^{3}\right)$ to the $618-11$ drum storage units, and $1.0 \mathrm{~m}^{3}\left(34.5 \mathrm{feet}^{3}\right)$ to the $618-11$ caissons.

Hazardous materials disposed of to 618-11 include the following:

- Cleaning solvents

- Ppainting materials

- Strip coat

- Small amounts of mercury

- Sample vials with acids $\left(\mathrm{HNO}_{3}, \mathrm{HCL}, \mathrm{HF}\right.$, and $\left.\mathrm{H}_{2} \mathrm{SO}_{4}\right)$

- Metallic sodium; metal alloys of chromium and nickel

- Nitrides and halides from molten salt, lead, beryllium residues, zirconium, thorium metal turnings, and uranium metal turning

Appendix F contains a list of general waste shipments made from 1962 through 1964 compiled from monthly activities reports (GE 1962-1964). Waste was sent to either the 618-10, $618-11$, or the $200 \mathrm{~W}$ sites. The $618-10$ site was used only when the $618-11$ burial ground was not available. The $200-\mathrm{W}$ burial ground was to be used for the high plutonium, but low beta/gamma dose rate waste. Appendix F data are summarized in Table 3-8: 


\begin{tabular}{|c|c|c|c|c|c|c|c|c|c|c|c|c|c|}
\hline 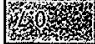 & $\angle 0$ & 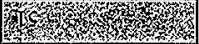 & IZZ'Z & I & $z$ & $o z$ & $\angle \tau$ & Fy. & - & $\varepsilon 6$ & 69 & $9 S Z^{c} t$ & $\left({ }_{\varepsilon} \mathrm{ux}\right)$ әưn \\
\hline 93 & 92 & $10941 \mathrm{k}$ & $\nabla 2$ & $L \varepsilon Z$ & 265 & 669 & 096 & 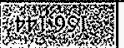 & - & $80 \varepsilon^{\prime} \varepsilon$ & $\tau \varepsilon \neq \succ \tau$ & tOt'OSI & 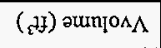 \\
\hline & $\triangleright \varepsilon 0^{\circ} 0$ & $\mathrm{~V} / \mathrm{N}$ & $b$ & $9 E \mathfrak{I}^{\prime} 0$ & I $89^{\circ} 0$ & ZIZ0 & $S^{\prime} L$ & $\mathrm{~V} / \mathrm{N}$ & - & $S L$ & $8 Z I$ & $S \bullet$ & 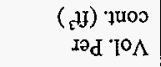 \\
\hline & $\$ 9 L$ & & 9 & $\nabla L I$ & $L$ & $86 z \varepsilon$ & $8 Z I$ & & $\mathfrak{l}$ & Itt & $6 I$ & $\varepsilon \tau t^{\prime} \varepsilon \varepsilon$ & IETOI \\
\hline - & 0 & & 0 & $8 \mathcal{E}$ & $0 t$ & $0 L \varepsilon$ & 0 & & 0 & 0 & 0 & 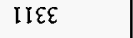 & ${ }^{\circ} \angle 96 \mathbf{I}$ \\
\hline & 0 & & 0 & $s$ & 9 & $8 \varepsilon t$ & 0 & & 0 & 0 & 0 & 0082 & 'E L96I \\
\hline & 0 & & 0 & $\angle I$ & 8 & $0 \varepsilon Z$ & 0 & & 0 & 0 & 0 & $\varepsilon I I Z$ & ๑ 996I \\
\hline & $\varepsilon Z I$ & & 0 & $6 I$ & $t$ & $\varepsilon I \varepsilon$ & 0 & & 0 & 0 & 0 & ZEIE & 'e 996I \\
\hline & $9+I$ & & 9 & $L t$ & 0 & $69 \varepsilon$ & 0 & & 0 & 0 & 8 & $\varepsilon \subseteq 6 \varepsilon$ & ૧ ९96I \\
\hline & SEI & & 0 & $8 t$ & 9 & $0 Z t$ & 0 & & 0 & $00 t$ & 0 I & $\varsigma Z Z \downarrow$ & ' $\$ 96 \mathrm{I}$ \\
\hline & $9 \varsigma$ & & 0 & 0 & $\varepsilon 乙$ & $\triangleright 8 \mathcal{E}$ & 0 & & 0 & 9I & 0 & SL8t & $9 \$ 96 I$ \\
\hline & OSI & & 0 & 0 & 0 & $s z b$ & 0 & & 0 & $s z$ & 0 & $0 S L E$ & ' $\mathrm{t}+96 \mathrm{I}$ \\
\hline & 08 & & 0 & 0 & 0 & ISI & $o z$ & & 0 & 0 & 0 & 0991 & ' q £96I \\
\hline & pasolo & & pasolo & pəso!๐ & pasolo & pasoio & pasoto & & pasolo & pasols & pasoło & pasoip & ' \\
\hline & 0 & & 0 & 0 & 0 & 0 & $\begin{array}{l}\text { peiaxouos } \\
\text { ot }\end{array}$ & & 0 & 0 & 0 & $z \succcurlyeq 9 l$ & 92961 \\
\hline & $S L$ & & 0 & 0 & 0 & $86 I$ & $\begin{array}{c}\text { радалото } \\
89\end{array}$ & & I & 0 & I & 2961 & $\cdot \mathrm{e} 296 \mathrm{I}$ \\
\hline 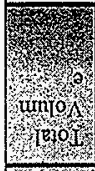 & 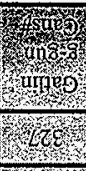 & 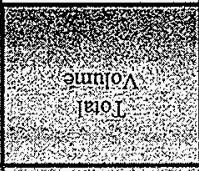 & 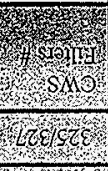 & Sy & 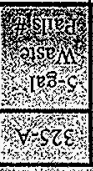 & 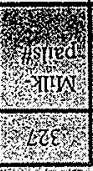 & 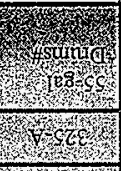 & 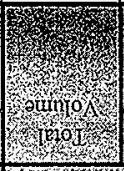 & 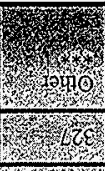 & 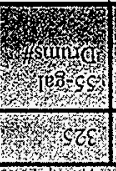 & 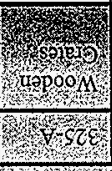 & 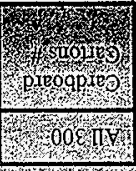 & 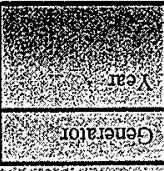 \\
\hline \multicolumn{2}{|c|}{ 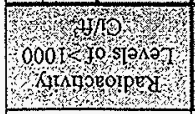 } & \multicolumn{6}{|c|}{ 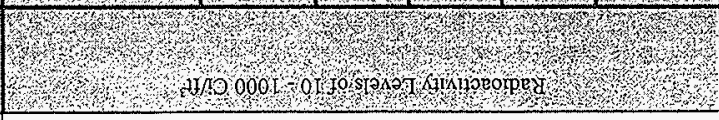 } & \multicolumn{6}{|c|}{ 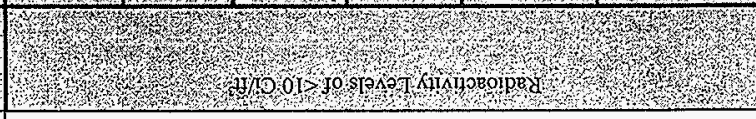 } \\
\hline uos & & & & (ว)ี. & unu & & & & & & पวuə.। & & \\
\hline
\end{tabular}


HNF-EP-0649, Rev. 0

Table 3-8: Solid Waste Disposal Summary 1962 to 1964 from Monthly Activity Reports

\begin{tabular}{|l|r|r|r|r|r|}
\hline Burial Site & \multicolumn{1}{|c|}{$\begin{array}{c}\text { No. of } \\
\text { Luggers }\end{array}$} & $\begin{array}{c}\text { Vol. of } \\
\text { Luggers } \\
\left(\mathbf{m}^{3}\right)\end{array}$ & $\begin{array}{c}\text { No. of Remote } \\
\text { Containers }\end{array}$ & $\begin{array}{c}\text { No. of Concrete } \\
\text { Barrels }\end{array}$ & $\begin{array}{c}\text { Vol. of Concrete } \\
\text { Barrels }\left(\mathbf{m}^{3}\right)\end{array}$ \\
\hline \hline $300-\mathrm{N}$ & 326 & 923 & 24 & 154 & 33 \\
\hline WYE & 573 & 1622 & 719 & 294 & 62 \\
\hline $200-\mathrm{W}$ & 81 & 229 & 0 & 81 & 17 \\
\hline & & & & & \\
\hline
\end{tabular}

At the end of 1964, PNL assumed the site operations contract from the General Electric Company. The monthly activity reports published by General Electric were replaced by monthly and quarterly operation reports published by PNL. The latter reports did not carry any information on solid waste generation or disposal. Therefore, a careful review was made of the 1965-66 radiation survey records of waste material shipments. These survey records are given in Appendix G. Table 3-9 summarizes the items shipped to the 618-11 burial ground in 1965 through 1967 from available shipping records. The table also summarizes the items and volume of waste materials shipped, as interpreted from the records. Some container volumes had to be estimated from the container description. Also, it appears that at least part of the 1967 records are missing.

Baker (1968) reported on the solid waste generated throughout the Hanford Site for the latter half of calender year 1967 . He reported that $422 \mathrm{~m}^{3}$ (14,900 feet $\left.{ }^{3}\right)$ of low-activity waste $\left(0-10 \mathrm{Ci} / \mathrm{feet}^{3}\right)$ had been disposed to the $618-11$ burial ground. In addition, the report said 13,358 feet $^{3}$ of PNL waste had gone to the 200 West burial ground. Only some of the PNL facilities are in the 300 Area. Using this facility base and earlier waste projections (Parks 1966), approximately $246 \mathrm{~m}^{3}\left(8700 \mathrm{ft}^{3}\right)$ of that material came from the 300 Area. Therefore, the 300 Area generated approximately $668 \mathrm{~m}^{3}$ of low-activity waste during the last half of 1967 according to these records. About 63 percent of the waste, by volume, had been disposed to the 618-11 burial ground. The $422 \mathrm{~m}^{3}$ six-month disposal rate at the $618-11$ burial ground compares with $420 \mathrm{~m}^{3}$ per six months based on burial records. 
Table 3-9a: Radiological Survey Records (PNL, 1965)

\begin{tabular}{|l|c|c|c|}
\hline \multicolumn{1}{|c|}{ Containers } & $\begin{array}{c}\text { Number of } \\
\text { Containers }\end{array}$ & $\begin{array}{c}\text { Container } \\
\text { Volume }\left(\mathbf{m}^{3}\right)\end{array}$ & $\begin{array}{c}\text { Total Volume } \\
\left(\mathbf{m}^{3}\right)\end{array}$ \\
\hline Boxes - plywood & 5 & 3.62 & 18.1 \\
\hline Boxes - wooden & 4 & 1.81 & 7.24 \\
\hline Concrete radiation boxes & 28 & 0.76 & 21.28 \\
\hline Dump-track loads & 3 & 7.64 & 22.92 \\
\hline Gatling-gun casks* & 33 & 0.0113 & 0.37 \\
\hline Small hot cell casks* & 64 & 0.0047 & 0.3 \\
\hline Large hot cell casks* & 70 & 0.0189 & 1.32 \\
\hline Large can cask** & 16 & 0.0566 & 0.91 \\
\hline Lead glass window & 1 & 0.566 & 0.57 \\
\hline Luggers & 195 & 2.83 & 551.85 \\
\hline Milk pail casks* & 235 & 0.006 & 1.41 \\
\hline Filters & 1 & 0.0113 & 0.11 \\
\hline Pumps & 2 & 0.09 & 0.18 \\
\hline Drums & 13 & 0.208 & 2.7 \\
\hline $\begin{array}{l}\text { Truck loaded with drums } \\
\text { and/or equipment }\end{array}$ & 17 & 8.32 & 141.44 \\
\hline Total & 418 &.- & 771 \\
\hline *Remote Containers & & & $\left(152 \mathrm{ft}^{3}\right)$ \\
\hline & & & $\left.\mathrm{ft}^{3}\right)$ \\
\hline & & & \\
\hline
\end{tabular}


HNF-EP-0649, Rev. 0

Table 3-9b: Radiological Survey Records (PNL, 1966)

\begin{tabular}{|c|c|c|c|}
\hline Containers & $\begin{array}{l}\text { Number of } \\
\text { Containers }\end{array}$ & $\begin{array}{c}\text { Container } \\
\text { Volume }\left(\mathbf{m}^{3}\right)\end{array}$ & $\begin{array}{c}\text { Total Volume } \\
\left(\mathrm{m}^{\mathbf{3}}\right)\end{array}$ \\
\hline Boxes - plywood & 6 & 3.62 & 21.72 \\
\hline Drums & 49 & 0.208 & 10.19 \\
\hline Dump-truck loads & 3 & 7.64 & 22.92 \\
\hline Gatling-gun casks* & 10 & 0.0113 & 0.11 \\
\hline Glove boxes & 2 & 2.72 & 5.44 \\
\hline Small hot cell casks* & 26 & 0.0047 & 0.12 \\
\hline Large hot cell casks* & 44 & 0.0489 & 0.83 \\
\hline Large can casks* & 14 & 0.0566 & 0.79 \\
\hline Luggers & 156 & 2.83 & 441.48 \\
\hline Milk pail casks & 128 & 0.006 & 0.77 \\
\hline $\begin{array}{l}\text { Truck load ( } 55 \text {-gal drums or } \\
\text { equipment) }\end{array}$ & 40 & 8.32 & 332.8 \\
\hline Truck load (35-gal drums) & 1 & 5.29 & 5.29 \\
\hline Truck load (15-gal drums) & 2 & 2.27 & 4.54 \\
\hline \multicolumn{4}{|l|}{ Miscellaneous: } \\
\hline Filters & 5 & 0.113 & 0.57 \\
\hline Concrete anchor & 1 & $\sim 0.2$ & 0.2 \\
\hline Furnace and controllers & 3 & $\sim 0.2$ & 0.6 \\
\hline Bird cages & 12 & 0.208 & 2.5 \\
\hline Ballast & 1 & $\sim 0.2$ & 0.2 \\
\hline Total & 503 & -- & $\begin{array}{c}851 \\
\left(30070 \mathrm{ft}^{3}\right)\end{array}$ \\
\hline *Remote containers & 222 & -- & $\begin{array}{c}2.62 \\
\left(92.6 \mathrm{ft}^{3}\right)\end{array}$ \\
\hline
\end{tabular}


Table 3-9c: Radiological Survey Records (PNL, 1967)

\begin{tabular}{|l|c|c|c|}
\hline \multicolumn{1}{|c|}{ Containers } & $\begin{array}{c}\text { Number of } \\
\text { Containers }\end{array}$ & $\begin{array}{c}\text { Container } \\
\text { Volume }\left(\mathrm{m}^{3}\right)\end{array}$ & $\begin{array}{c}\text { Total Volume } \\
\left(\mathbf{m}^{3}\right)\end{array}$ \\
\hline \hline Boxes - plywood & 16 & 3.62 & 57.92 \\
\hline Drums & 5 & 0.208 & 1.04 \\
\hline Filters & 2 & 0.113 & 0.23 \\
\hline Gas bottles & 2 & $\sim 0.1$ & 0.2 \\
\hline Large hot cell casks & 1 & 0.0047 & 0.005 \\
\hline Large can casks & 2 & 0.0566 & 0.11 \\
\hline Luggers & 7 & 2.83 & 19.81 \\
\hline Truck-loads (Drums) & 2 & 8.32 & 16.64 \\
\hline \multicolumn{1}{|c|}{ Total } & 37 & & 96 \\
& & & $\left(3390 \mathrm{ft}^{3}\right)$ \\
\hline
\end{tabular}




\subsection{LOW-ACTIVITY CONTAMINATED WASTE}

Low-activity wastes include any contaminated or potentially contaminated material from general operations, laboratory, and other working areas outside of gloveboxes, hot-cell, and reactor core work. These wastes were generally classified as containing $<10 \mathrm{Ci} / \mathrm{feet}^{3}$. Such waste is collected in the standard 18 inch square by 24 inch high cardboard carton that have a large radiation symbol painted on each side. Filled cartons were stored outside the main buildings in load luggers. The cartons were typically disposed of at the 618-11 burial ground in an open trench. Waste additions to the trench were covered weekly or sooner if required. Waste in steel drums, concreted and lead-lined steel drums, wooden boxes, and plastic wrapped spent equipment were also buried in the trenches. These packages contained cut-up equipment that was too heavy or too difficult to package or contaminated items that exceeded the radiation limit of a carton. Cartons only had a 65 pound weight limit.

The normal waste output for the 327 building was about 50 cartons per week (12 shift operation). The 325 building generated approximately a truck load, or 25 cartons per week. Radiation levels generally varied from about 5 to $200 \mathrm{mr} / \mathrm{hr}$ at one foot from a sealed carton. However, much higher readings were encountered on occasion, and drivers sometimes had to trade off driving chores on the burial ground run to keep from exceeding personal radiation exposure levels.

Other buildings in the 300 Area that generated cardboard carton wastes disposed at 618-11 burial ground included 324, 3706, 321, 340, and occasionally the 306, 308, 309, and 329 .

\subsection{INTERMEDIATE-ACTIVITY CELL WASTE}

Intermediate-activity waste was classified as containing 10 to $1000 \mathrm{Ci} / \mathrm{feet} 3$. This waste was produced in large quantities in five of the 327 building hot cells. Intermediate activity waste was disposed in expendable waste cans, and milk pails during the 1960 s. The intermediate waste was generated primarily from the 327 building hot cells, although some came from either the 325-A or 325-B hot cell. Table 3-10 gives a reasonable representation of the waste from the 327 building. Waste from the $325-\mathrm{A}$ hot cells would contain more equipment and hardware. The $325-\mathrm{B}$ hot cells would contain small vials, bottles, and both solid and liquid analytical samples and sample residues. Most liquid samples were acid solutions or slurries. These intermediate waste forms from the 325 building hot cells represent moderately radioactive materials, but exclude most irradiated materials. These wastes were primarily disposed to the drum storage units.

Radiation levels for loaded intermediate waste casks were generally the same, or slightly higher than those of radioactive waste cartons. The radiation levels were typically $200 \mathrm{mR} / \mathrm{hr}$ at one foot, with occasional higher readings. Table 3-11 is a list, obtained from 327 operations log 


\section{HNF-EP-0649, Rev. 0}

books, of the milk pails shipped from the 327 building hot cells from January 1965 through June 1966. During that 18 month period, 346 pails were generated giving an average rate of 19 pails per month. The table also shows which cells generated the milk pails. 
Table 3-10: Metallurgical (327 Building)

Waste Materials

Tampon wipes

Paper towels

Tissues

Plastic sheeting

Paper or cardboard sheeting

Plastic pipe caps

Plastic vials and caps

Corks

Nylon sample grinding caps

Rubber stoppers

Rubber tube caps

Steel pipe plugs

Glass dishes

Nylon paint brushes

Tubing cutters

Stanley utility knives

Plastic bags

Grinding discs

Polishing discs

Aluminum brads

Cotton swabs

Manipuiator boots and bands

Ice cream cartons

Aluminum weights and blocks

Stainless blacks

Paint spray cans (punctured)

Cloth rags

Plastic bottles

Rubber canner gloves

Other varieties of gloves

Small tools

Small or cut-up equipment items

Small or cut-up instrument items 
HNF-EP-0649, Rev. 0

Table 3-11: Number of Milkpails from 327 Building

\begin{tabular}{|c|c|c|c|c|c|c|c|c|c|c|c|}
\hline & \multicolumn{9}{|c|}{ Cell } & \multirow[b]{2}{*}{ Total } & \multirow[b]{2}{*}{$\begin{array}{l}\text { Total Volume } \\
\left(\mathrm{M}^{3}\right)\end{array}$} \\
\hline Date & A & B & $\mathrm{C}$ & D & $\mathbf{E}$ & F & $\mathbf{G}$ & B-NORTH & B-SOUTH & & \\
\hline Jan- 65 & & & 2 & & & 5 & & & & 7 & 0.05 \\
\hline Feb-65 & 10 & 6 & 19 & & & & & & & 35 & 0.23 \\
\hline Mar-65 & & & 2 & 2 & 1 & 2 & & & & 7 & 0.05 \\
\hline Apr-65 & 9 & 3 & 18 & 2 & 12 & 6 & & & 1 & 51 & 0.34 \\
\hline Jul-65 & & 6 & 1 & & & & & & & 7 & 0.05 \\
\hline Aug- 65 & 5 & & 1 & 1 & & & 1 & & & 8 & 0.05 \\
\hline Sep-65 & 5 & & & & & 5 & & & & 10 & 0.07 \\
\hline Oct-65 & 3 & & 1 & & 3 & & & & & 7 & 0.05 \\
\hline Nov- 65 & 2 & & & & & 3 & & & & 5 & 0.03 \\
\hline $\operatorname{Jan}-66$ & 6 & 2 & 11 & 2 & 6 & 7 & 4 & & & 38 & 0.25 \\
\hline Feb-66 & 8 & 4 & & & 12 & 10 & & & & 34 & 0.22 \\
\hline Mar-66 & 7 & 2 & 5 & 5 & 12 & 8 & 4 & 7 & 1 & 51 & 0.34 \\
\hline Apr-66 & 5 & 1 & 4 & 1 & 6 & 8 & 3 & & & 28 & 0.19 \\
\hline May-66 & 10 & 1 & 7 & 4 & 7 & 5 & 1 & & & 35 & 0.23 \\
\hline Jun-66 & 1 & 2 & 4 & 4 & 6 & 3 & & 3 & & 23 & 0.15 \\
\hline Total & 71 & 27 & 75 & 21 & 65 & 62 & 13 & 10 & 2 & 346 & \\
\hline $\begin{array}{l}\text { Total } \\
\text { Volume } \\
\left(\mathrm{M}^{3}\right)\end{array}$ & 0.47 & 0.18 & 0.5 & 0.14 & 0.43 & 0.41 & 0.09 & 0.07 & 0.01 & 2.29 & \\
\hline & & & & & & & & & & & \\
\hline
\end{tabular}




\subsection{HIGH-ACTIVITY WASTE}

High-activity wastes were primarily irradiated nuclear fuels and materials upon which tests, assays, or lab studies were performed. It also included materials used in fission product recovery, and purification studies from either irradiated fuel or liquid waste streams. The work activity generating these wastes was separate from the plutonium production process. Highactivity waste is classified as containing greater than $1,000 \mathrm{Ci} /$ feet $^{3}$.

High-activity waste generated in the 325-A hot cells was packaged in one-gallon paint cans with crimp-on lids. These cans were filled with various types of wipes, samples, tools, and cut up equipment. The cans were typically loaded on a push through trough that was loaded in the cell, then pulled back into the cask. The cask lid was closed and the cask was removed from the hot cell. General radiation exposure levels of high-activity waste were determined to be about $1,000 \mathrm{R} / \mathrm{hr}$ at the surface of the waste with occasioned hot spots up to $10,000 \mathrm{R} / \mathrm{hr}$. Table 3-3 summarizes the hot cell waste generated from 1961 through 1967 at the 325-A cell facility obtained from the operating logs (Appendix A). The high-activity waste is limited primarily to the one and five-gallon can material transported in the shielded one and seven-ton casks. The 15-gallon black iron cans and similar materials were generally regarded as intermediate level wastes (significantly reduced dose rate) and were generally disposed of to the drum storage units. The high-activity one and five-gallon cans were disposed to the caisson units.

The volume of high-activity waste that went to the $618-11$ burial ground from the 325-A hot cells was approximately $164 \mathrm{~m}^{3}$ of trench waste, $9.6 \mathrm{~m}^{3}$ of drum storage unit waste, and $5.6 \mathrm{~m}^{3}$ of caisson waste, based on the information in Table 3-3.

High-activity waste from the 327 building was canned in a commercial one-quart juice can that was disposed using the gatling-gun cask. The cask provided seven inches of lead shielding and handled 12 cans in a rotating six barreled chamber.

\subsection{TRANSURANIC CONTENT}

References vary widely on waste plutonium contents disposed to the 618-11 burial ground. Some inconsistencies even occur within the same record. However, a number of references provide the approximate plutonium content for the 618-11 burial ground. Voiland (1970) says $<100$ grams of plutonium were disposed at $618-11,<1,000 \mathrm{Ci}$ beta/gamma, and approximately $120,000 \mathrm{feet}^{3}$ of buried waste. Then Voiland (1970) states tens to hundreds of grams of plutonium and thousands of curies of beta/gamma were disposed of there. Speaking in general about plutonium content at the 618-11 burial ground, Voiland states: "Recognized plutonium wastes were either contained in concrete, confined to the caissons or shipped to 200 West burial sites." Berreth (1963) says some of the wastes will contain plutonium in fractional grams or greater. Backman (1964) reports that $3.51 \mathrm{~g}$ of plutonium went out in the liquid waste for 
July 1964 and $1.15 \mathrm{~g}$ in August. However, no plutonium values were listed for the 10 concrete drums, 94 load luggers of waste cartons, and 171 containers of high level dry waste that were disposed during those two months to the 618-11 burial ground. During the same two month period nine concrete drums and 13 load luggers of waste cartons were disposed to the 200 West Area (Backman 1964). An effort was made from the fall of 1963 through 1967 (Berreth 1963) to ship recognized plutonium waste from the 308 and 325 buildings to 200 West for disposal. However, there were exceptions. Building 325 generated hot cell wastes and other high dose rate plutonium wastes that were shipped to the 618-11 burial ground. Therefore, by the fall of 1963, low-activity plutonium waste from 308 and some from 325 building went primarily to the 200 West Area rather than the 618-11 burial ground. Essentially all other 300 Area buildings and facilities, including $321,327,3706,340,306,324,3718$, and 326 sent waste only to the $618-11$ burial ground. The PRTR (309 building) sent waste to the $618-11$, but a small portion also was sent to 200 West.

Stevens (1963) indicates that multi-curie content plutonium waste with $\mathrm{Sr}^{90}$, and other isotopes have been encased in concrete prior to disposal at the 618-10 and 618-11 burial grounds. Geiger (1977) indicates that $100 \mathrm{~g}$ of known plutonium were disposed to the $618-11$ burial ground, but indicates that records were not certain. The plutonium value might be on the order of five kg. Coony (1985) lists the 618-11 site as having 10,000 grams of plutonium or about 960 curies. That is the value also listed on the most recent reference (DOE 1987), 10,000 g of plutonium and $960 \mathrm{Ci}$ of TRU waste. The document also listed the disposed waste volume at $7,900 \mathrm{~m}^{3}$ and overburden volume at $18,000 \mathrm{~m}^{3}$. If credit is taken for the overburden soil in determining the plutonium density, the $618-11$ burial ground exhibits a TRU density of $68 \mathrm{nCi} / \mathrm{g}$. The waste would then be considered non-TRU if the overburden soil is accepted as contributing to the weight of the waste. If the overburden soil is not considered as contributing to the waste weight, the waste is TRU.

An overwhelming number of references agree that the drum storage units and caissons are TRU waste. Corley (1967) states that waste packages with significant amounts of $\mathrm{Pu}^{239}$ have been disposed in the silos (drum storage units and caissons) at the 618-11 burial grounds. .

More in-depth discussions about the plutonium content of the trenches revealed that both TRU and non-TRU waste was buried in the standard waste carton. In addition, the concrete drums buried in the trench often contained TRU solid and liquid waste. No data are available, nor is there an easy way to estimate, the plutonium content of the concrete drums. However, an estimate of the balance of the trench content can be made from available data on 300 Area laboratory waste generated in 1968 and also assay data from the 1970s (Cooley 1975).

Hall (1969) listed the burial volumes and plutonium contents of waste from the various Hanford Site sectors. PNL is listed as having generated $1,355 \mathrm{~m}^{3}\left(47,900\right.$ feet $\left.^{3}\right)$ of waste containing $18.5 \mathrm{~kg}$ of uranium, $1,020 \mathrm{~g}$ of plutonium, and 1,590 Ci of radioactivity. An 
appreciable portion of the waste volume might have come from PNL operating areas other than the 300 Area. However, the plutonium content is primarily from the 300 Area. Therefore, it appears that the solid waste being generated in the 300 Area in the mid-1960s was contaminated with approximately one $\mathrm{kg}$ of plutonium per year. Other TRUs such as americium were generally ignored unless they were SMN material. Therefore, the actual TRU content would be slightly higher because the burial ground also contains $U^{233}$ and $U^{235}$, neptunium, americium, and perhaps curium and californium.

The laboratory waste generated in the 1960 s was mostly packaged in standard cardboard cartons. Little effort was made to distinguish between non-TRU (fission, by-product, or activation product) and TRU waste (Craddock 1975). All waste was packaged and placed in building load luggers. In addition, carton-type waste also included CWS filters from open-face hoods, plutonium gloveboxes, and hot cell facilities. The filters were generally packed in the original $\left(4.0\right.$ feet $\left.^{3}\right)$ cardboard cartons.

The plutonium content of the 618-11 burial ground trenches was estimated in three different ways:

- Specific survey information from the first half of 1975 was used to calculate an average plutonium density.

- The total plutonium content of the waste for the mid-1970s was totaled and corrected to give a total plutonium content.

- An estimate of the plutonium and other TRUs handled in the 300 Area in the mid-1960s was made. The amount going to waste, including the 618-11 burial ground, was estimated.

The data given in Table 3-12 show that from January through June 1975, 1,530 feet ${ }^{3}$ of TRU waste were generated against a total waste volume of 16,704 feet $^{3}$. This gives a 9 percent TRU fraction (10 percent being quite typical in the 1970s). During the same period, $723.2 \mathrm{~g}$ of plutonium were assayed in the waste, amounting to an average plutonium density of $0.043 \mathrm{~g} /$ feet $^{3}$. The total volume of trench waste listed for the 618-11 burial ground was 155,151 feet $^{3}$. Multiplying the density times the total volume gives a total plutonium estimate of $6,720 \mathrm{~g}$. The waste weighed approximately 127 pound/drum or $16.93 \mathrm{lb} /$ feet $^{3}$. Assuming the plutonium to be mostly $\mathrm{Pu}^{239}(0.08 \mathrm{Ci} / \mathrm{g})$, the trench TRU density totals approximately $450 \mathrm{nCi} / \mathrm{g}$, which is 4.5 times the TRU limit. Diversion of some of the waste from the 308 and 325 buildings to the 200 West disposal area probably resulted in a 10 percent reduction in the amount of plutonium buried, so the plutonium density would be about $400 \mathrm{nCi} / \mathrm{g}$. Therefore, it still appears that wastes disposed to the 618-11 trenches is TRU, based on total waste average. No correction was made nor credit given for soil overburden. If the volume and weight of the 
overburden soil (density 6 to 7 times waste) is considered as part of the waste, the plutonium density less than $100 \mathrm{nCi} / \mathrm{g}$ and it would be non-TRU.

Table 3-12: 300 Area Waste Shipment volumes Generated by Hanford Engineering Development Laboratory

\begin{tabular}{|l|r|r|r|r|}
\hline \hline $\begin{array}{l}\text { Waste Designation (in ft } \\
\text { Transuranic } \text { (TRU) }\end{array}$ & $\begin{array}{l}\text { CY-1973 } \\
\text { July - Dec. }\end{array}$ & \multicolumn{1}{l|}{$\begin{array}{l}\text { CY-1974 } \\
\text { Jan. - June }\end{array}$} & $\frac{\text { CY-1974 }}{\text { July - Dec. }}$ & $\frac{\text { CY-1975 }}{\text { Jan. - June }}$ \\
\hline \hline Non-TRU (FP \& other) & 13,215 & 20,715 & 16,779 & 15,174 \\
\hline TRU & 3,320 & 883 & 1,088 & 1,530 \\
\hline Total & 16,535 & 21,598 & 17,867 & 16,704 \\
\hline Percent Non-TRU & $80 \%$ & $96 \%$ & $94 \%$ & $91 \%$ \\
\hline
\end{tabular}

Using the second method to estimate the plutonium content, the average 300 Area waste content from 1974 through 1977 was used to project a plutonium value. The plutonium values are given in Table 3-13.

Table 3-13: Plutonium in 300 Area Waste

\begin{tabular}{|c|r|}
\hline Date & Total Pu \\
\hline CY-1974 & $1,304 \mathrm{~g}$ \\
CY-1975 & $1,579 \mathrm{~g}$ \\
CY-1976 & $669.7 \mathrm{~g}$ \\
CY-1977 & $1,053.8 \mathrm{~g}$ \\
& \\
Total & $4,606.5 \mathrm{~g}$ \\
\hline
\end{tabular}

Four years of nuclear operations generated waste material contaminated with $4,606.5 \mathrm{~g}$ of plutonium. The $618-11$ burial ground was open about 4.8 years, with a projected generation of $5,528 \mathrm{~g}$. The trench plutonium density based on the latter estimate would be $375 \mathrm{nCi} / \mathrm{g}$. Correction for 10 percent diversion to the 200 West Area would make that approximately $335 \mathrm{nCi} / \mathrm{g}$. This indicates the trench wastes are TRU.

Another way to estimate the plutonium content of the 618-11 burial ground is to approximate the amount of plutonium being handled by the 300 Area during the period. Section 3.1.1 indicated that at least $2,400 \mathrm{~g}$ of plutonium were expected to have been disposed to the 
618-11 burial ground from PRTR activities. Other work activities, mentioned in Section 3.1.2, indicate a substantial amount of non-PRTR work occurred, such as radionuclide separations, reprocessing studies, 327 studies on non-PRTR fuels, and radiochemical analyses. Many of these activities involved the use of plutonium, neptunium, or other transuranics.

The 325 building operated under a criticality limit of $2000 \mathrm{~g}$ per laboratory and $230 \mathrm{~g}$ per fissile station (Berreth 1962). The building operating limit over the years has varied, but was typically five $\mathrm{kg}$ fissile. The actual operating fissile inventory was typically two to three $\mathrm{kg}$. The 327 building handled less fissile material. Their limit was approximately $230 \mathrm{~g}$ per cell. The 327 building had ten hot cells and some other fissile stations. The 327 building typically operated at about 20 percent of their fissile limit, which calculates to be about $500 \mathrm{~g}$. The approximate minimum fissile inventory total for the two buildings would be $2,500 \mathrm{~g}$.

Other buildings, such as $326,3706,329,3718$, and other small facilities, were primarily limited control facilities with a maximum fissile limit of $170 \mathrm{~g}$ fissile. Other facilities such as the $324,340,305$, and 306 varied depending on the work activities. During the 1960 s these facilities had nuclear safety specifications that allowed greater than $170 \mathrm{~g}$ fissile, but lesser fissile quantities than nuclear facilities like the 325 or 308 buildings. The total fissile inventory of the rest of the 300 Area was perhaps another $2,500 \mathrm{~g}$. It seems reasonable to expect that during and 4.8-year operation of the 618-11 burial ground, most of the 300 Area fissile inventory would have been tested, analyzed, synthesized, metalographed, processed, or otherwise treated and discarded to waste. Therefore, the 300 Area waste fissile material inventory, combined with that from the PRTR would generate about five $\mathrm{kg}$ of plutonium waste that would have been disposed to the 618-11 burial ground. In addition, there was approximately one $\mathrm{kg}$ of designated plutonium waste material that was sent to 200 West for disposal.

\subsection{TRU CONTENT COMPARISONS}

The 618-11 burial ground TRU content figures presented in this document need to be compared with other well documented waste disposal sites. Other Hanford waste disposal figures and national waste disposal figures can be compared to validate the 618-11 TRU content figures presented.

The SWITS database lists the volume of solid waste generated since Hanford Site operations began in 1944 through 1967 in Table 3-14. It shows that during that time $164,916 \mathrm{~m}^{3}$ $\left(5,827,420 \mathrm{ft}^{3}\right)$ of waste was generated. That waste contained an estimated $347,205 \mathrm{~g}$ of . plutonium for an estimated average density of $2.1 \mathrm{~g} / \mathrm{m}^{3}$ compared with that of $1.4 \mathrm{~g} / \mathrm{m}^{3}$ estimated for the 618-11 burial site. 
Table 3-14: The Average Hanford Site Soild Waste Fissile Density

\begin{tabular}{|c|c|c|c|c|}
\hline Year & $\begin{array}{c}\text { Waste Volume } \\
\left(\mathrm{m}^{3}\right)\end{array}$ & $\begin{array}{l}\text { Accumulative } \\
\text { Volume }\left(\mathbf{m}^{3}\right) \\
\end{array}$ & $\begin{array}{c}\text { Pu Content } \\
\text { (g) }\end{array}$ & $\begin{array}{l}\text { Accumulative } \\
\text { Pu Content }\end{array}$ \\
\hline 1944 & 14 & 14 & 0 & 0 \\
\hline 1945 & 2104 & 2118 & 1340 & 1340 \\
\hline 1946 & 2161 & 4279 & 1340 & 2680 \\
\hline 1947 & 3576 & 7855 & 1435 & 4115 \\
\hline 1948 & 3520 & 11,375 & 1435 & 5550 \\
\hline 1949 & 3607 & 14,982 & 6415 & 11,965 \\
\hline 1950 & 4822 & 19,804 & 21,360 & 33,325 \\
\hline 1951 & 4737 & 24,541 & 31,320 & 64,645 \\
\hline 1952 & 5434 & 29,975 & 32,335 & 96,980 \\
\hline 1953 & 5747 & 35,722 & 30,200 & 127,180 \\
\hline 1954 & 7153 & 42,875 & 31,700 & 158,880 \\
\hline 1955 & 9010 & 51,885 & 33,340 & 192,220 \\
\hline 1956 & 8317 & 60,202 & 34,905 & 227,125 \\
\hline 1957 & 8807 & 69,009 & 31,965 & 259,090 \\
\hline 1958 & 7797 & 76,806 & 32,555 & 291,645 \\
\hline 1959 & 7739 & 84,545 & 6975 & 298,620 \\
\hline 1960 & 8914 & 93,459 & 3300 & 301,920 \\
\hline 1961 & 5125 & 98,584 & 5890 & 307,810 \\
\hline 1962 & 5834 & 104,418 & 565 & 313,505 \\
\hline 1963 & 4980 & 109,398 & 6160 & 319,665 \\
\hline 1964 & 5802 & 115,200 & 6500 & 326,165 \\
\hline 1965 & 25,059 & 140,259 & 6450 & 332,615 \\
\hline 1966 & 5101 & 145,360 & 6660 & 339,275 \\
\hline
\end{tabular}


Table 3-15 summarizes waste characteristics from the commercial burial sites. The activity of the commercial burial sites is reviewed for comparative purposes only. The table shows the waste volumes buried at commercial disposal sites throughout the United States during 1966, 1967, and 1968. The SNM density average for the sites was $1.7 \mathrm{~g} / \mathrm{m}^{3}$ for the entire country, drawn from only the commercial waste burial sites. The fissile content of the 618-11 burial ground, based on estimates in this document, place it less than the overall Hanford solid waste fissile average and less than the commercial nuclear waste for a comparable time frame. This demonstrates that Hanford fissile waste loading disposed to the 618-11 burial ground parallels the expected norm. With all the diversified operations conducted in the 300 Area (reactors operations, fuel fabrication, fuel reprocessing or reprocessing studies, analytical support, fuel testing, and materials separations and purification), to produce a waste that exhibits an average or slightly less than average comparable fissile density is conceivable.

Table 3-15: Fissile Density of Commercial Waste Buried During 1966-67

\begin{tabular}{|l|c|r|r|r|}
\hline \hline Burial Site & Year & $\begin{array}{c}\text { Waste Volume } \\
\left(\mathbf{m}^{\mathbf{3}}\right)\end{array}$ & $\begin{array}{r}\text { Fissile Content } \\
(\mathbf{g})\end{array}$ & $\begin{array}{c}\text { Fissile Density } \\
\left(\mathrm{g} / \mathbf{m}^{\mathbf{3}} \mathbf{)}\right.\end{array}$ \\
\hline \hline Morehead, KY & 1966 & 5,560 & 7,462 & 1.34 \\
& 1967 & 7,820 & 14,842 & 1.90 \\
\hline Sheffield, IL & 1967 & 2,530 & 1,238 & 0.49 \\
& 1968 & 2,710 & 1,754 & 0.65 \\
\hline Beatty, NV & 1966 & 3,530 & 5,782 & 1.66 \\
& 1967 & 3,210 & 22,644 & 7.05 \\
\hline Richland, WA & 1966 & 2,403 & 1,418 & 0.59 \\
& 1967 & 870 & 0.16 & 0.0002 \\
\hline
\end{tabular}

\subsection{SOURCE MATERIAL AND BY-PRODUCT CONTENT}

An accurate accounting of source material and beta/gamma by-product material (uranium and thorium) was either lost or not kept for 618-11 burial ground wastes. However, 300 Area shipping records for the 1965-67 time period (see Appendix G) contains information that will allow estimation of the source material content. Also, the beta/gamma curie content can be estimated from volume of the different waste activity levels summarized in Table 3-7 for the whole 1962-1967 time period. 
The shipping records indicate that at least seven truck loads and two load luggers of thorium waste, five truck loads of uranium waste, and at least four drums of uranium/thorium metal turnings scrap were disposed of in the 618-11 burial site during 1965-1967. Assuming each waste drum in the truck load contained one to $10 \mathrm{~kg}$ of source material contamination, approximately $100 \mathrm{~kg}$ per load lugger, and each drum of scrap weighed $100 \mathrm{~kg}$, there is about $3,000 \mathrm{~kg}$ of source material present. In addition, assume about $1,000 \mathrm{~kg}$ of source material present in miscellaneous waste cartons not initially identified as containing the material. The total disposed would be $4,000 \mathrm{~kg}$. Additionally, fuel fabrication operations were ongoing, so source material contamination was being generated. It is assumed that an additional $2,000 \mathrm{~kg}$ of source material from fuel fabrication was disposed. This quantity is small because $\mathrm{N}$ - Reactor did not become operational until 1964. This gives a total of $6,000 \mathrm{~kg}$ of source material disposed at the 618-11 burial ground. Approximately one-third or $2000 \mathrm{~kg}$ was uranium, with the majority being slightly enriched uranium ( 0.95 or higher). In total, the site could contain three to four $\mathrm{kg}$ of U-235 SNM in excess of the natural uranium (0.72\%). 


\subsection{RADIOACTIVE RELEASES (UPDATED 9/29/97)}

The use of the 618-11 burial ground for disposal of a wide variety of radioactive materials has resulted in occasional radioactive contamination releases. In general, the contaminated area was isolated as quickly as possible, uncontaminated soil placed over the contaminated soil, and packed in place. The area was then surveyed to ensure that the contamination was completely covered. A record of site contamination releases, including 618-11 burial ground, is given in Appendix $\mathrm{H}$.

Appendix H, a chronology of contamination incidents from 1956 through 1971, lists nine incidents at the 618-11 burial ground. The Hanford Inactive Site Surveillance database given in Appendix I lists only seven incidents at the 618-11 burial ground. Appendix I omits contamination incidents dated January 14, 1965; October 12, 1965; and October 17, 1967. Appendix I also has incident information for September 30,1963 at the 327-2 drum storage unit at 618-11 and differs from Appendix $\mathrm{H}$, which indicates 618-10 burial grounds as the location of the incident. The issue of location seems to be cleared up with General Electric, 1962-1964. Reported in the October 1963 Monthly Activities Report is the following: "The "Wye" burial ground, contaminated during a milk pail dumping operation, was cleaned satisfactorily". This leaves little issue that the contamination spread of September 30, 1963 occurred at the 618-11 burial ground. Therefore, there were a total of 10 reported contamination incidents at the 618-11 burial ground.

All radioactive release incidents, except two (Appendix I) indicate contamination spreads occurred while dumping wastes into the caisson or drum storage units. Only one incident report provides wind direction data and another reports the contamination spread was limited to a fan shaped area extending northeast from the dump chute (Appendix I). Hanford meteorology wind data from meteorology Station 12 (closest to the site), indicate that winds blow almost exclusively from the northwest, west, or southwest. These data would support contamination spreads to the northeast, east, or southeast.

One incident report also indicates water was sprayed on contaminated areas to wash contaminants into the soil and inhibit wind-aided spread of material (Appendix I). Spray downs to control contamination spread have been widely used at Hanford before or during waste disposal and during construction excavations. R. L. Spinks, a 327 building worker, also recalls coal clinkers being dumped around some caisson units so trucks could get traction in the sandy soil. This would also aid in keeping contamination down. Presence of the coal clinkers could account for the black strip seen in Figures 2-9 and 2-10.

Cadwell (1971) records, "the most extensive contamination spreads occurred at the 300 North and 300 Wye burial grounds. The contamination is not detectable at the present time because of radioactive decay, dispersion by wind and rainfall, or because of action taken at the time such as blending of the dirt, occurred to cover the contamination. The area north of the 
618-11 burial ground was bladed in 1967 to cover fission product (primarily $\mathrm{Ru}^{103}$ ) contamination spread in April of that year."

Wind erosion and subsequent contamination spreads were reported on several radiological survey sheets through 1974. Uptake of short-lived fission products by plants and grasses led to discovery of plant seeds or dried plants reading up to 40,000 counts $/ \mathrm{min}$. Small subsidences were also reported, which were of additional concern for further contamination spread (Maxfield 1973). To control the situation and ensure that unauthorized personnel would not enter the 618-11 burial ground area, an eight-foot chain-link fence was erected around the burial ground in July 1974 (J.A. Jones 1974 and ARCO 1974). The secured burial ground (eight-foot chain-link fence) is apparent in Figure 2-11.

Several loads of earth fill and gravel were placed on the burial ground to cover contamination spots (Maxfield 1974a and 1974b). A final stabilization effort to end sporadic contaminations and secure the area for the Washington Public Power Supply System operation was conducted in June 1982. It included two additional feet of soil, seeding the soil with grass, and irrigating the seeded fill. Semi-annual and quarterly surveys taken from 1982 until 1992 reported no detectable contamination above background levels (Conklin 1982, and Borup 1992). Monitoring of the burial ground continues. 


\subsection{BURIAL GROUND CLOSURE (UPDATED 9/25/97)}

\subsection{JUSTIFICATION}

The decision to move burial grounds away from the 300 Area was made in the 1950 s due to projected high dose rate exposures to site and fire personnel (Gerber 1992). The decision to close the $618-10$ burial ground was based on the same reasoning. Fires or wind-borne contamination accidents would likely contaminate large areas and close Highway 45 (Backman 1963a). Also, the AEC was in the process of reviewing the burial ground location (General Electric, 1962-1964) and recognized the contamination potential and the adverse public opinion to contaminations that could impact a large population of employees or off site personnel. Land off the 200 Area plateau was also recognized as being released for reuse or free access in the future (Keene 1963 and Corley 1967). The following concerns and policies about burial practices at 618-11 were first documented in April 1963 (Backman 1963a):

- The only sites suitable for all types of solid waste disposal were located on the 200 Area plateau.

- Severe contamination spreads at a single burial ground would limit the use of the site for extended time periods.

- Current policies and procedures to control radiation exposure, the disposition of radioactive materials to the ground, and the minimization of disposed sites were given.

- The "Wye" burial ground would be continued only until the capacity of the existing trench is exhausted.

Berreth (1963) discussed the need to dispose of plutonium wastes in fractional grams or greater quantities and requested guidance to be able to do so. Backman (1963b) indicated that several facilities in the 300 Area were working with plutonium, and that the plutonium wastes should be segregated and disposed of to the 200 Areas. Stevens (1963) indicated that wastes containing multi-curies of plutonium, $\mathrm{Sr}^{90}$, and other isotopes were encased in concrete and disposed of at the 300 Area (618-10 and 618-11) burial grounds. Stevens also questioned the need, other than fencing, to control the 300 Area disposal sites and proposed allowing some contaminated solid wastes containing plutonium and Sr-90 to be buried at 618-11. Keene (1963) recommended that Hanford laboratory facilities dispose of plutonium or $\mathrm{Sr}^{90}$ containing wastes to the 200 Area burial sites because further site diversification and the establishment of new industries would allow more non-project people contact with 300 Area burial sites.

Consequently, the 300 Area burial sites and the wastes to be received by them would become more difficult to control. A reference of actual implementation of procedures or policies to limit disposal of certain radionuclides by gram quantity or curie activity, which "shall be disposed to the 200 Area burial grounds" was not found, although general company or facility guidance was given (Berreth 1962 and BNWL 1967). 
The justification to close the 618-11 burial ground seems to have come as an Atomic Energy Commission (AEC) document. Corley (1967) indicates that the final text of the AEC-RL00 Manual, Chapter 0510 will state that solid wastes containing certain long-lived nuclides, including Sr-90, Cs-137, and Pu-239 should be buried only on the 200 Area plateal. The reference also states that the purpose of the burial ground closure "is to avoid unreasonably long ( $>100$ years) denial of other potential usage of land containing isolated waste disposal sites, as well as to provide longer soil columns to ground water for nuclides of both long half-life and high radiotoxicity". The reference also states that waste packages with significant amounts of $\mathrm{Pu}-239$ have been disposed in the silos (drum storage units and caissons) at the 618-11 burial ground.

In Hall (1967), support for the forthcoming AEC closure is given and suggests alternatives be examined to be better prepared when the closure request came. The burial ground was closed December 31, 1967.

\subsection{STABILIZATION}

After the closure of the 618-11 burial ground on December 31, 1967, all plutonium and mixed-fission product wastes were transported to the 200 Area plateau for disposal. Closure of the 618-11 burial ground basically ended all solid waste disposal in or around the 300 Area, except for one trench burial ground north of 300 Area that accepted only uranium fabrication wastes (SNM by-product material).

After the 618-11 closure, both the TRU and low-activity beta-gamma wastes were combined and disposed to trenches in the 200 East and 200 West Areas It was not until April 1970 that the AEC ruling was issued directing contractors to separate waste containing TRU elements, and to place it in retrievable storage. Retrievable waste was to be separated from other radioactive wastes because of concerns about long-lived toxicity. However, segregating TRU wastes from non-TRU wastes took several years to implement in some facilities (Craddock 1975). Moderate and high-activity beta-gamma wastes were disposed to the 200 West Area beta-gamma caissons in one-gallon and five-gallon buckets. Larger, moderate or high-activity wastes (boxes, drums, and equipment) were shielded and disposed in the 200 West Area trenches as remote-handled (RH) waste. All solid wastes having contact dose readings of 200 $\mathrm{mR} / \mathrm{hr}$ or greater were designated $\mathrm{RH}$ when disposed.

Final site closure housekeeping was made during 1968 (Corley 1968, Hall 1968). Hall (1968) listed the final site closure activities for the 618-11 burial ground. The entire site was backfilled and covered with a four foot layer of soil. Perimeter radiation concrete posts (1.5 m high, $0.3 \mathrm{~m}$ in diameter) were installed in 1968 (Cadwell 1971). The posts were fitted with stamped brass radiation hazard markers which included topographical coordinates (Cadwell 1971). The retired burial ground was placed on a monthly survey surveillance.

Native grasses and tumbleweeds began to revegetate the site. The contamination incidents at the site made subsurface contamination available to the plant life. Dispersion of 
contamination by wind began to be a problem. The wind dispersion, combined with uptake of contaminants by deep-rooted plants, particularly tumbleweeds, and reported subsidences at the site, gave typical survey readings of 20,000 to $40,000 \mathrm{cpm}$ on the site surface (Maxfield 1973, 1974a). It appears the site was surveyed monthly through July 1974, although Corley (1967) requested only an annual survey.

The unauthorized entries (Saueressig 1981) and continued spread of contamination by plants and wind, justified enclosing the 618-11 site with an eight-foot chain-link fence. Localized contamination was covered with gravel and three loads of soil (Maxfield 1973, 1974b, 1974c). The fence to curtail access to the site was approved and erected on July 25, 1974 (J.A. Jones 1974).

The site continued to be plagued by plant and wind erosion contamination problems. Radiation surveys T81-1138 (October 31, 1981), T82-0222 (February 23, 1982), T82-0487 (April 5, 1982), and T82-0527 (April 14, 1982) report radiation counts to $30,000 \mathrm{cpm}$. Soil coverage attempts to control contamination at the site were not successful.

A final stabilization was initiated in April 1982 (Bracken 1982). The stabilization effort placed two additional feet of soil over the site and leveled the soil with heavy equipment (WHC 1983). The stabilization effort was completed on June 9, 1982. The site was then seeded with crested wheat grass and irrigated for 6 weeks. The radiation survey conducted after stabilization indicated no radiations levels above background (Conklin 1982).

Subsequent surveys, conducted after 1982, indicate the soil overburden intact, no detectable radiation levels above background, and the crested wheat grass has adapted well and covers approximately 90 percent of the site surface (Figure 5-1). Documented confirmation is best provided by Borup (1992). Borup's July 1992 radiation survey report is an example of the "no detectable contamination" survey reports. Radiation surveys of the 618-11 burial ground from the 1982 stabilization work through 1987 were done semi-annually. In 1988, the radiation survey frequency of the site was increased from semi-annually to quarterly, which is the current frequency schedule. 


\subsection{MONITORING AND SURVEILLANCE (UPDATED 9/30/97)}

\subsection{WATER TABLE DATA}

The location of the $618-11$ burial ground relative to the water table and moisture penetration from rainfall indicate that the minimum depth to ground water beneath the site is 18 $\mathrm{m}(59 \mathrm{ft})$ (Brown 1977). In 1974, rainfall at the Hanford Site was 170 percent of normal. That rainfall penetrated less than $5.5 \mathrm{~m}(18 \mathrm{ft})$ into the sediments at a field test site located south of the 200 East Area. A normal rainfall would typically penetrate two to four $\mathrm{m}(6.5$ to $13 \mathrm{ft})$ (Geiger 1977). The data also indicated that on the average, more moisture has evaporated from the ground than has been recharged by precipitation. Below nine meters $(29.5 \mathrm{ft})$, the sediments are extremely dry. In this desiccated zone, the ability of sediments to transmit water is significantly reduced (Brown 1977). Shortly after the 618-11 site was closed, it was covered with four-feet of soil. An additional two-feet of soil was added during final stabilization in 1982. This means that the bottoms of the trenches and eight-foot diameter caissons are now 31 feet below grade. The bottoms of the drum units are 21 feet below grade. All metal storage units that have been used are capped with a concrete plug. Thus, the probability that any contaminants have been leached into the soil below the burial grounds due to precipitation is extemely low. Although the bottoms of the metal storage units and some caissons are open, only plastic wrapped or containerized solid waste has been stored there. Any liquid accompanying the solid waste will have been fixed with adsorbents and will not have traveled significantly in the extremely dry soil at that depth.

\subsection{WELL MONITORING}

Monitoring wells were chosen to present upstream and downstream data. Permeation rates are not included, although they are low. The relative time for water to flow between two typical monitor wells is measured in terms of monthly units. Well \#8-17 is approximately 2.87 miles west/southwest of the burial site and is upstream in the water table, although flow proceeds south of the site approximately 1.5 miles. Well \# 15-15B is approximately 2.34 miles west/northwest and upstream from the site and is nearly in a direct water table line with the site. It is also nearly in a direct flow line from the burial site. Figure 6-1 shows these relationships. Figures 6-2 through 6-5 show concentrations of tritium, nitrate, beta, and alpha both upstream and downstream from the site. In some of the graphs, the concentration of radionuclides appears to be higher downstream and in others it appears to be lower. This is probably due to peaks passing wells at intervals, the low permeation rate, the southerly location of Well \#8-17, and the fact that it is approximately 5.2 miles between wells \#15-15B and \#10-E12.

A detailed study would needed to determine whether this specific burial site is contributing to groundwater or subterranean contamination. The study would need to include both groundwater sampling and soil sampling. The general groundwater monitoring program for the Hanford Site has shown that no appreciable radioactive contamination has been detected in the groundwater that can be attributed to buried solid radioactive waste (Geiger 1977). However, comprehensive and detailed burial ground site studies have not been done to confirm these results. 


\section{Figure 6-1: Hanford Site Map}

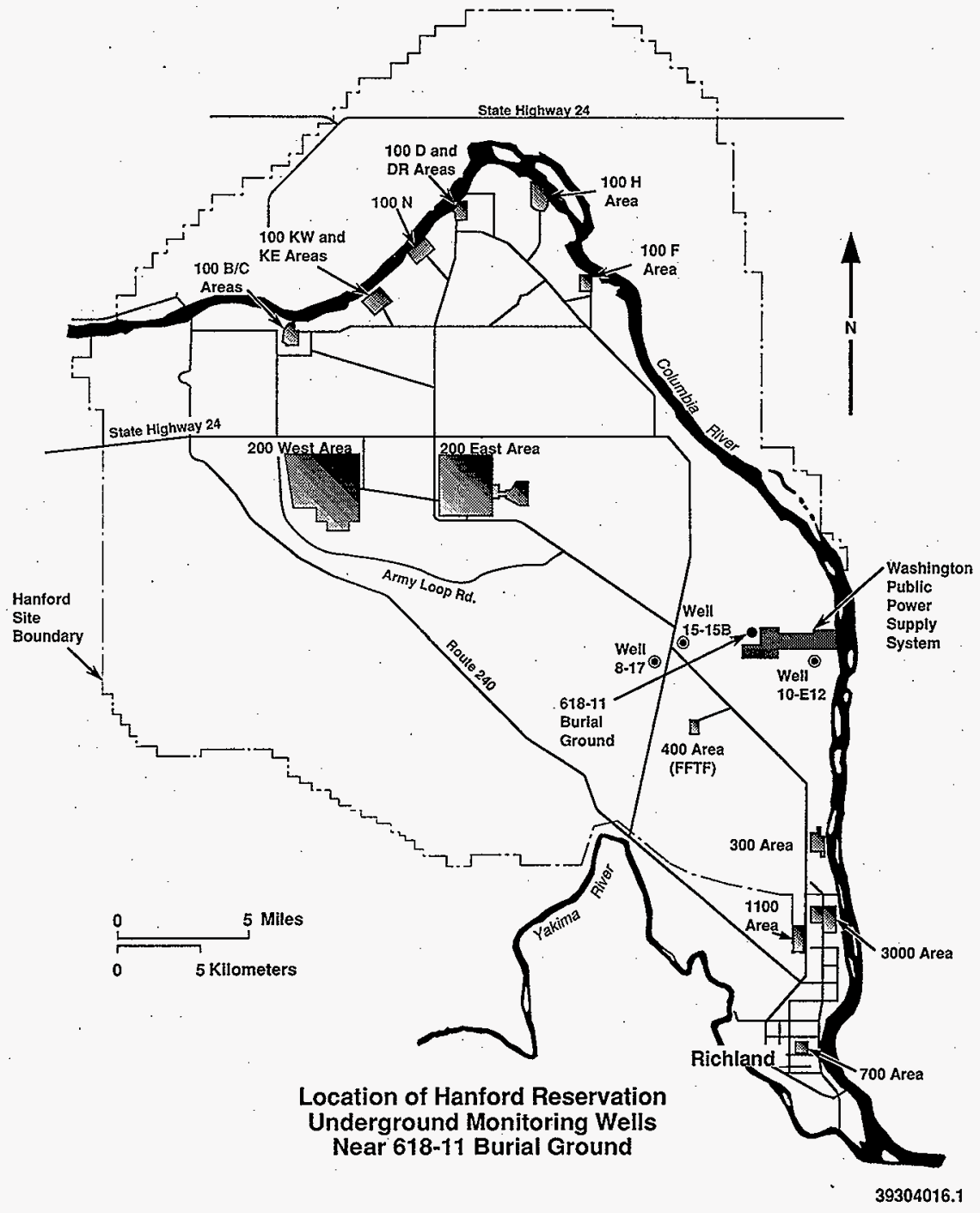


Figure 6-2: 618-11 Burial Site Tritium Concentration

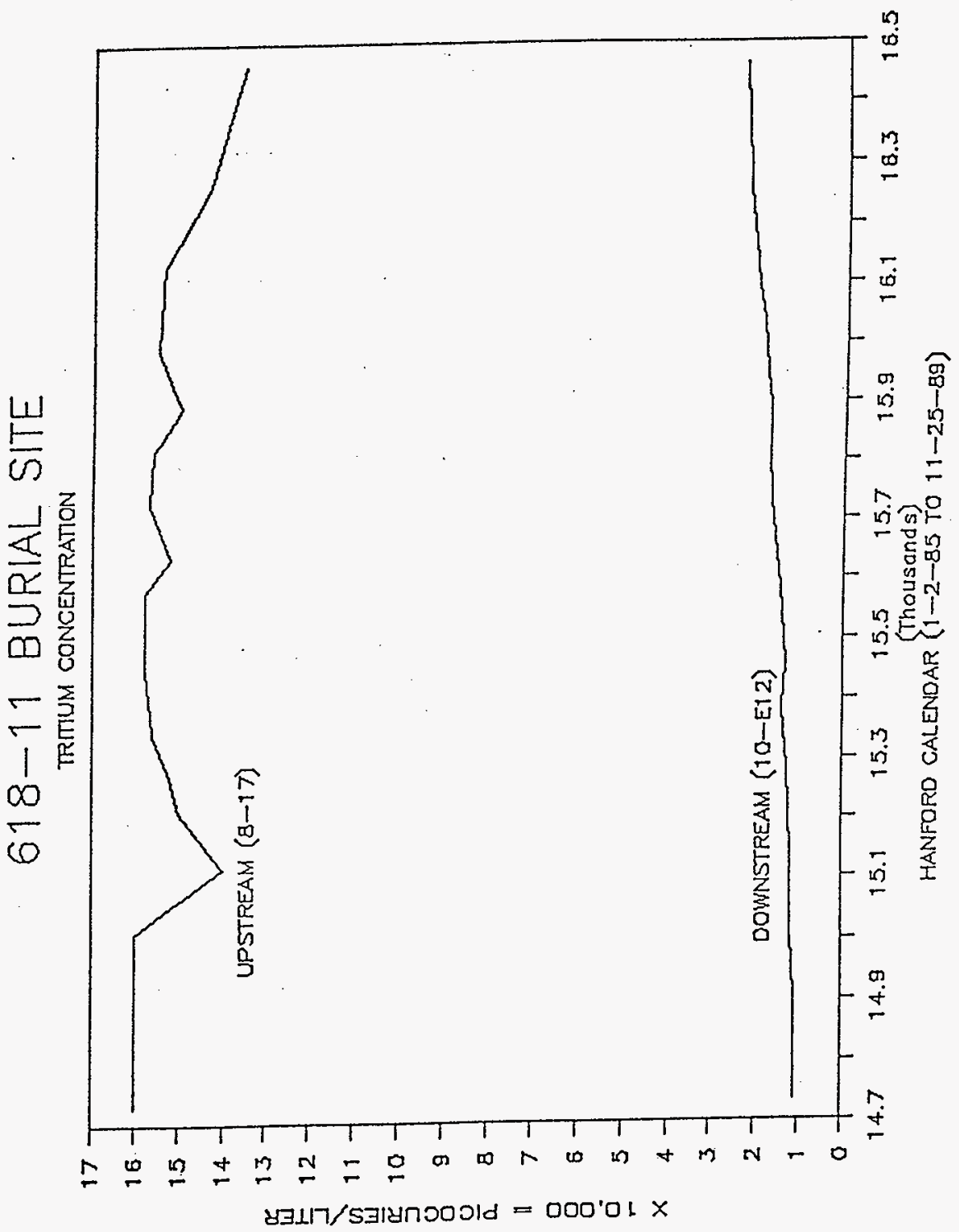




\section{8-11 BURIAL SITE}

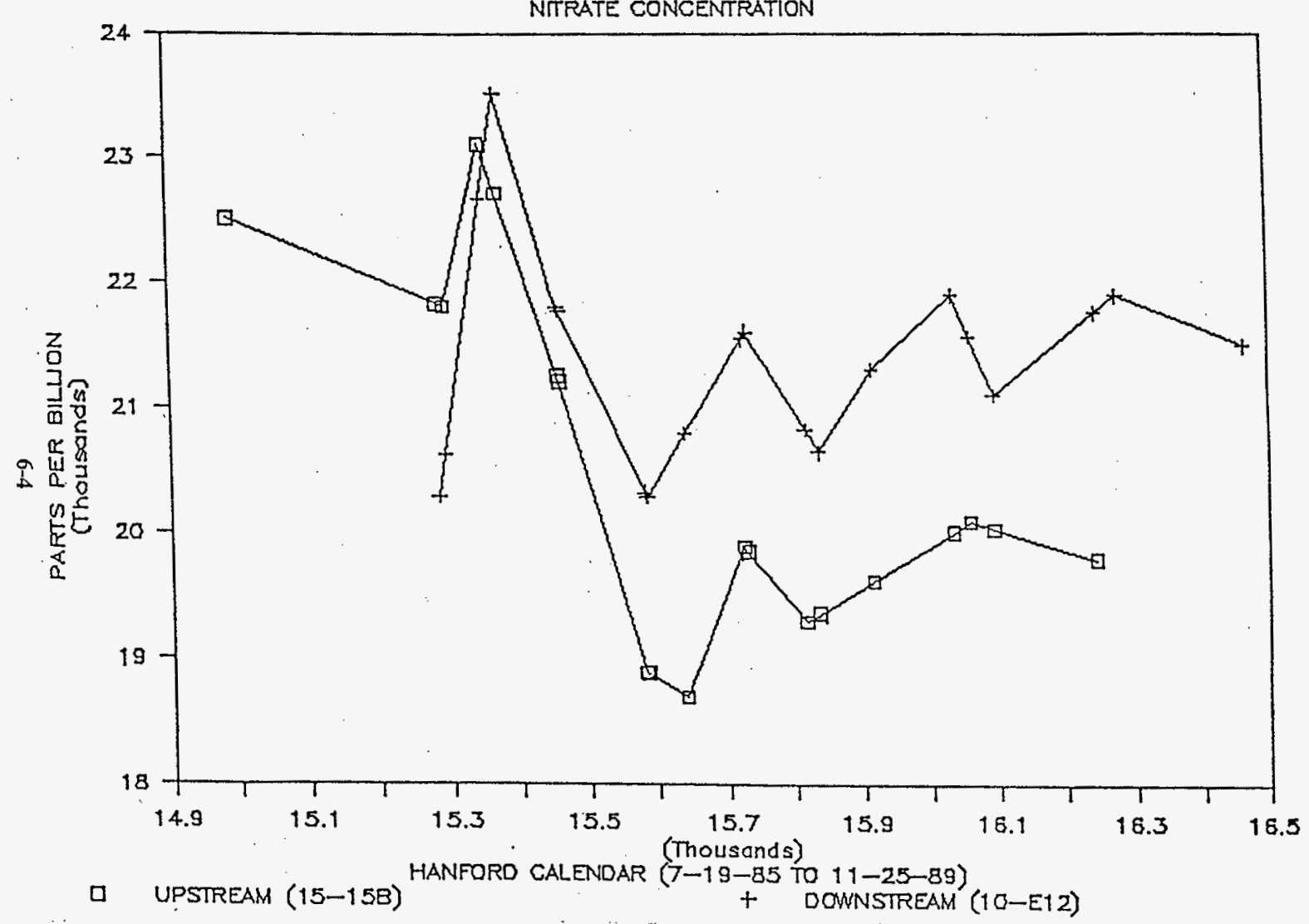

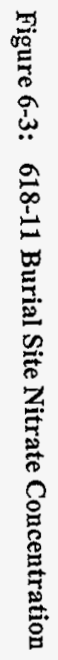




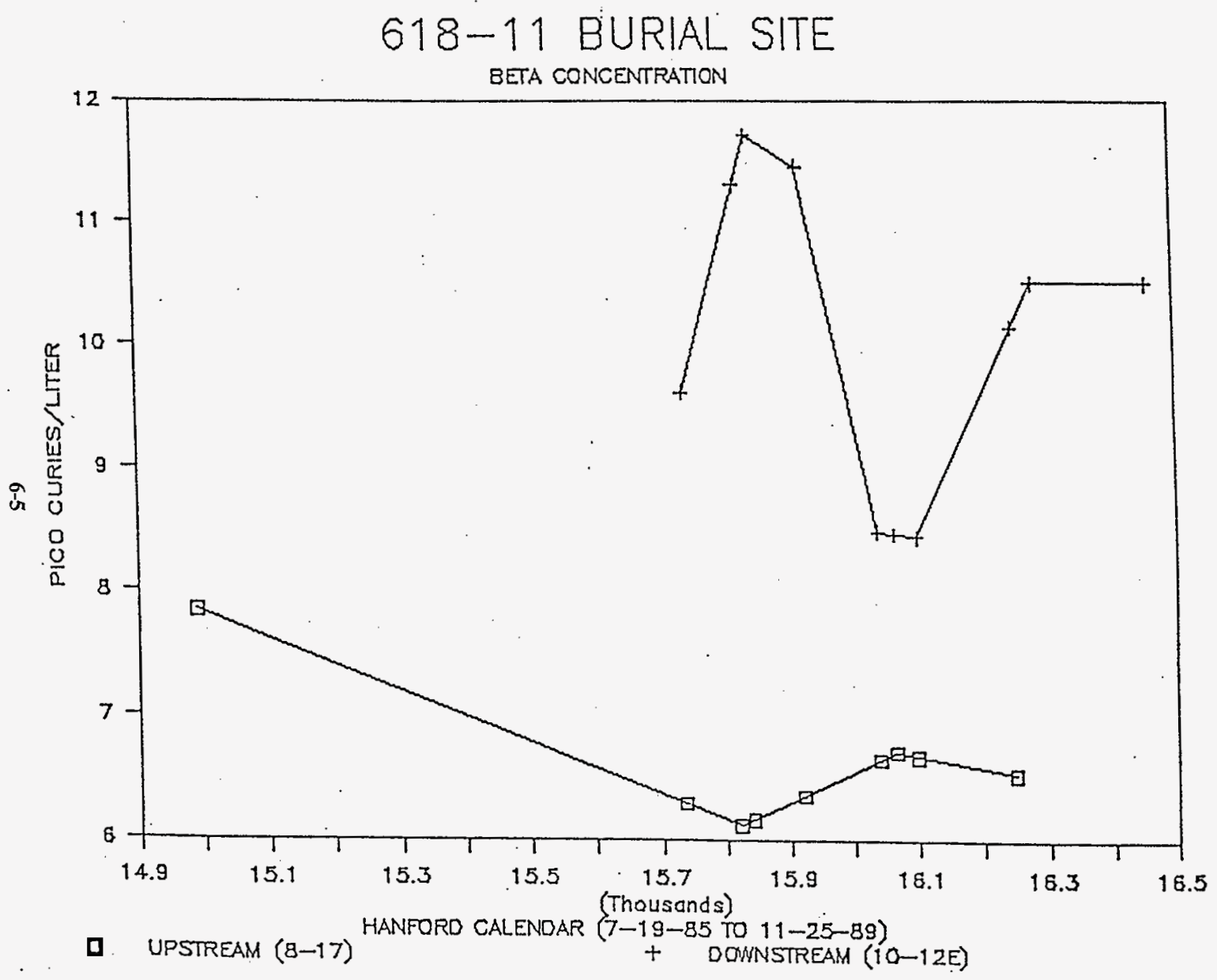




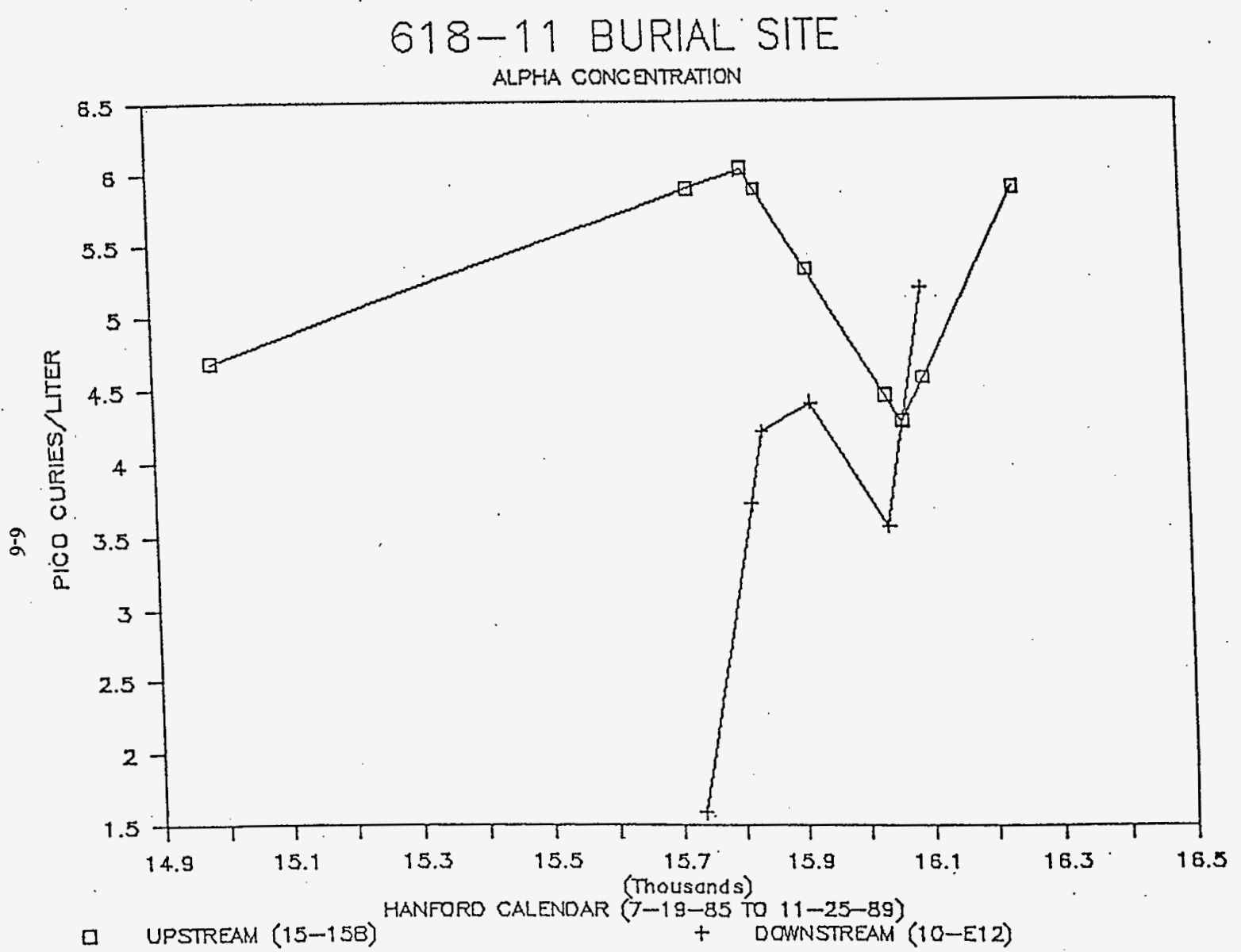


An attempt to characterize the 618-11 site by geophysical means was made in 1978 because, "quantitative evaluation of the migration of radiocontaminants from burial structures would provide information far more useful than site inventory" (Phillips 1980). Phillips reports on core drilling and sampling from four 300 Area burial grounds, including 618-11. The locations of the core drilling and sampling are not given. Therefore, determining whether the sampling was done nearer the caissons, drum storage units, or trenches is not possible. The document states that, "the wells were located to enable drilling beneath the structure where radiocontaminated leachate, if present, would be intercepted, rather than drilling into the structure."

Phillips (1980) reports two sample locations at 9.4 and $8.8 \mathrm{~m}$ deep in depth for the $618-11$ burial ground. (No indication is given if they are from the same core drill site.) After evaluating the core samples, the document reports gross alpha, gross beta, and other natural occurring radionuclides to be within background range. Phillips indicates $\mathrm{Cs}^{137}$ was found at sample location $\# 2$ (at the $8.8-\mathrm{m}$ depth) with an activity range of $0.13 \pm 0.05 \mathrm{pCi} / \mathrm{g}$. The report indicates that $\mathrm{Cs}^{137}$ was found only at the 618-10 and 618-11 burial grounds (Phillips 1980).

In addition, a search was conducted on the Hanford Environmental Information System (HEIS) for information concerning chemical and/or radiological analyses associated with wells within Hanford Plant coordinates N17500, N5500, W6500, and E6500. (Plot Plan H-6-930 lists the approximately northwest corner of $618-11$ as N12478, W3562; the southeast corner as N12103, W2562.) The search was concluded on February 4, 1993 and focused on wells listed on Table 6-1. Other wells are known to have existed in the area. All known wells specifically deleted from the search were seismic shot holes with very little possibility of any associated soil and/or groundwater analytical sampling data. The well data provided year of sample, analytical class, and number of results per class. Results of total samples associated with each well are shown in the Table 6-1.

Some of the data are historical, and not validated to current practice. Data may have been gathered for wells not shown, but they are not available in this major database. Well names reflect their location. An explanation of well names and details such as coordinates, casing diameter, drill depth, screen intervals, etc., may be found in McGhan (1989).

The three wells in closest proximity to the 618-11 burial ground are 699-13-1A, 699-13-1B, and 699-13-1C. These wells were sampled for potable water. Wells $1 \mathrm{~A}$ and $1 \mathrm{~B}$ are shallow wells ( 240 and $260 \mathrm{ft}$ respectively), and $1 \mathrm{C}$ is a deep well going down into the basalt bedrock. Well $1 \mathrm{C}$ is not currently being used because it brings up too much sand. 
Table 6-1: HEIS Monitoring Well Data

\begin{tabular}{|c|c|c|}
\hline Well Name & Count & Year \\
\hline 699-11-1A & 4 & 1973 \\
\hline $699-12-4 \mathrm{~B}$ & 246 & $1984-88$ \\
\hline $699-13-1 \mathrm{~A}$ & 99 & $1973-81$ \\
\hline 699-13-1B & 85 & $1973-81$ \\
\hline $699-13-1 \mathrm{C}$ & 74 & $1980-92$ \\
\hline 699-14-E6P & 69 & $1966-82$ \\
\hline 699-14-E6Q & 83 & $1967-81$ \\
\hline 699-14-E6R & 60 & $1967-81$ \\
\hline 699-14-E6S & 62 & $1967-81$ \\
\hline 699-14-E6T & 101 & $1966-88$ \\
\hline $699-17-5$ & 587 & $1951-92$ \\
\hline 699-9-E2 & 571 & $1958-87$ \\
\hline
\end{tabular}

\subsection{SITE MONITORING}

Sections 4.0 and 5.2 discussed historical site monitoring of the $618-11$ burial ground from site closure through stabilization in 1982, and up to present day monitoring activities. Hall (1968) gives the condition of the site shortly following closure, and at least four references attest to numerous contamination release concerns that existed until final site stabilization in 1982. Conklin (1982) provides the monitoring survey data before and after stabilization. Stabilization success is confirmed by a recent site survey showing no detectable contamination above background at the 618-11 site (Borup 1992).

Some recent site monitoring data were generated with the completion of the Ultrasonic Ranging and Data System (USRADS) mapping conducted February 4 through 10, 1993. The USRADS radiological survey results of the 618-11 field survey are given by Wendling (1993). The survey reported the gross gamma radiation detected while walking the site with hand-held backpack-mounted instrumentation. The system automatically logs gross gamma readings at approximately six-inches and three-feet from the soil surface.

The survey was a comprehensive compilation of data points conducted over the 10 grids laid out in the 618-11 burial ground. Each of the 34,321 data points represents two gross gamma radiation readings: counts per minute at six-inches, and dose rate at three-feet. The survey results for dose rate and count rate are given in the 3-D contour (Figures 6-6 and 6-7). The view is looking from the southwest corner.

The results indicate the 618-11 burial ground has no individual data point that exceeds background. (The background was taken at a "low background" site between 100-D/100-DR and the 100-H Areas.) The survey located the highest elevation dose rate and count rates in the

$$
6-8
$$


Figure 6-6:

\section{8-11 USRADS SURVEY \\ RADIOLOGICAL PROFILE}

DOSE RATE

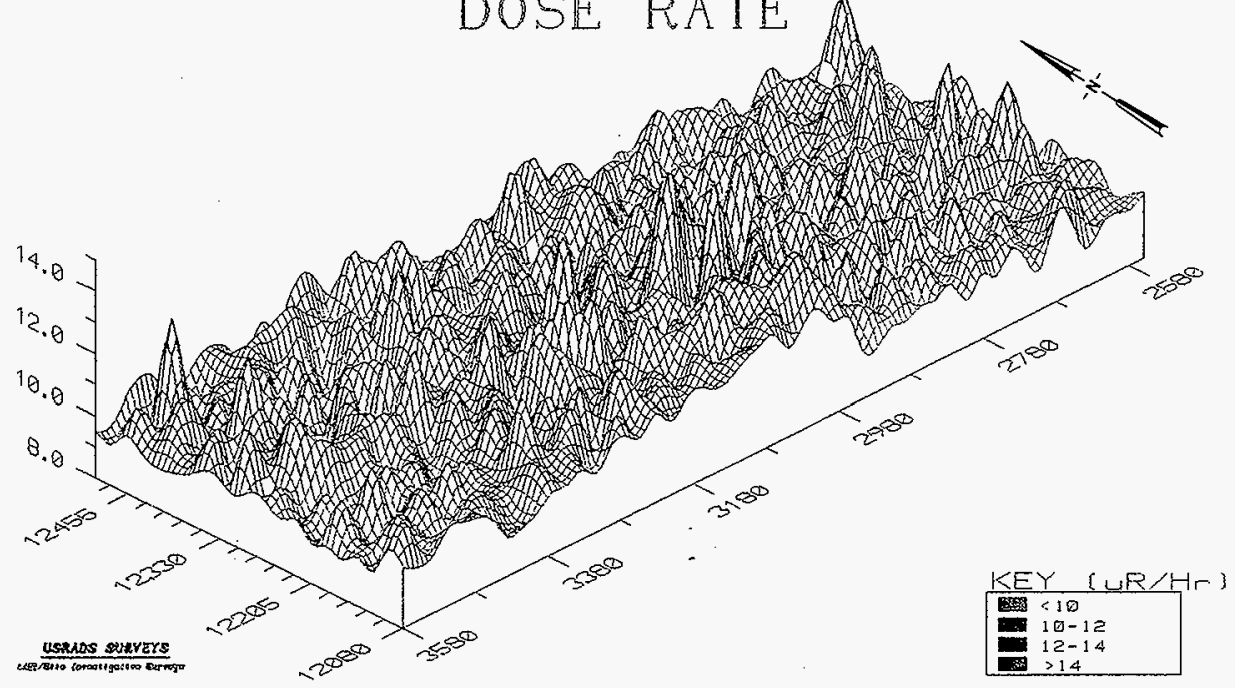


Figure 6-7:

\section{8-11 USRADS SURVEY RADIOLOGICAL PROFILE COUNT RATE (2X2 NaI)}

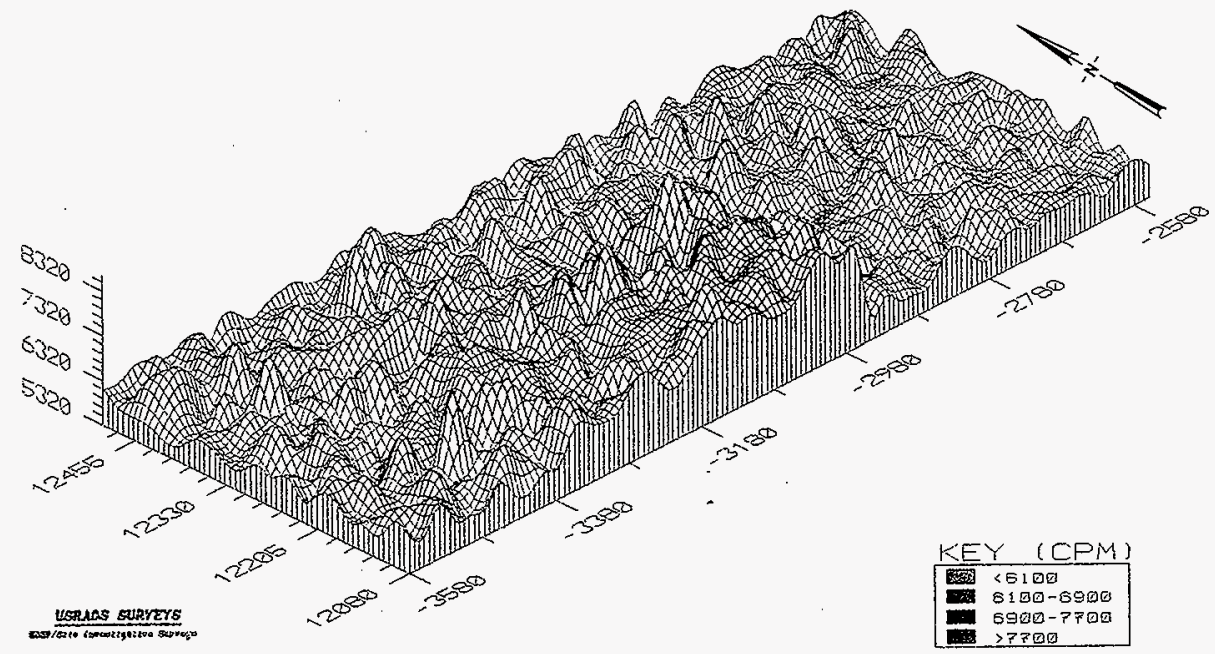


HNF-EP-0649, Rev. 0

618-11 burial ground, which are along the southern boundary proceeding north to the area of the eight-foot diameter caissons.

The predominate winds blow from the west. With all the backfill and blading of soil and gravel at the site, it is impossible to determine how Figures 6-6 and 6-7 support or negate contamination incidents. The survey does indicate that the final stabilization effort taken in 1982 is still effective.

The most current characterization survey of 618-11 burial ground was the geophysical investigation completed in 1995 (Bergstrom 1997). A geophysical survey of the burial site was conducted using GPR and EMT. Both methods are nonintrusive, environmentally safe, and cost effective. The GPR method uses a transducer to transmit FM frequency radio energy into the ground. Interfaces in the ground reflect back the transmitted energy. The GPR did not provide any new data locating the drum storage units and caissons and correlated well with existing geophysical documentation. The GPR did however confirm that Trench \#3 was only partially filled with waste.

EMI investigates the electrical conductivity properties of subsurface soil, rock, and in this study drums, vessels, tanks, and caissons. Figure 2-15 shows the recent EMI results of the 618-11 burial site (Bergstrom 1997). Its data is in complete agreement with site drawing H-6-930. The results confirm that there are 50 drum storage units and five anomalies (caissons) west of the drum storage units along N450. The drum storage units and caissons are visible as contour circles. The fields created by wastes in the trenches are also visible as contour lines. Trench \#1 is located along N350, Trench \#2 along N250, and Trench \#3 along N150.

Caisson location data can be confirmed by additional geophysical investigations. The GPR grid for this investigation was 10 feet. If the site was redone on a two-foot grid, in the area of the caissons, the details of the western five anomalies could be better defined. The tighter grid would determine the number of caissons and the caisson layout along N12,428.24 (Figure 2-11). 


\subsection{INTERVIEWS}

The recent destruction of 618-11 waste shipping manifests and the 300 Area SNM records left a significant information gap in the content of wastes generated and shipped to the 618-11 burial ground during operations in 1962 - 1967. Personal interviews were conducted with active and retired 300 Area facilities employees, who were in any way concerned with solid waste in the mid-1960s. Attention was directed particularly to 325 and 327 building employees, because these two facilities were the primary solid waste generators. The intent of the interviews was to locate written records about burial site practices, shipment information, or other related data. It became apparent only a few employees (past or present) retained much written information. The information obtained from individual files was incomplete for rebuilding the missing waste burial records.

However, some written records were obtained or located through interviews. These records, along with published documents and other preserved engineering records, helped establish the basis of this report. The following types of records were located through interviews:

- Photographs
- Lurvey records
- Exters
- Drawings and sketches
- Luried waste tabulations
- Logbook data

Most of the employees whose work was closely connected to the 618-11 burial ground work are now deceased. The majority of those still living, are retired and many have moved from the Tri-City area. Interviews with employees or retirees who possessed no written information were informative and interesting. These interview yielded controversy or another name to interview. Most interviews yielded hearsay or "as I remember it" information. This type of information usually was confusing or difficult to verify or confirm. A list of individuals interviewed who were considered knowledgeable of the 618-1I burial ground and its practices is given in Greenhalgh (1995).

Some Hanford Site records were available from archives in Auburn or Seattle, Washington. These records were reviewed on an individual basis. These records were primarily radiation survey records for the various 300 Area facilities. They have provided some supportive documentation; however, company rules for maintaining or archiving records vary among Hanford contractors. Many records were required to be maintained for only five years. In practice, most records generated in the 1960 s were stored for at least 10 years before they were either archived or destroyed. Most of the information needed for complete characterization of the $618-11$ burial ground was not preserved. This has limited the burial site characterization. 
Other information sources could not be pursued due to time limitations.' One area that could still potentially produce some information is the employee laboratory notebooks from 308 , 325,327 , and 340 Buildings. These records are listed on the classified card files of the 300 Area Technical Library (PNL) and the notebook documents are either stored or archived. These records could provide some additional data, if they can be located, and reviewed. Most of the formal, letter, and company reports generated by operating personnel in the 1960s have been reviewed. 


\subsection{RECOMMENDATIONS}

Uncertainties or deficiencies concerning the 618-11 burial ground exist for the site itself, the wastes disposed of, and the documentation that describes both.

Documentation concerning the site uncertainties is discussed in Sections 2.4.1 and 2.5. Waste disposal deficiencies are discussed in Section 3.6. The above uncertainties were caused by the length of time since the site was operated, and by the poor collection of historical records having to do with waste burial records. Recommendations are given to increase the confidence level required for site remediation. The recommendations are as follows:

Site

1. Conduct a new GPR scan in the area of the caissons. Use a scan grid of about two feet to provide more detailed data to the exact number, size, and location of the caissons west of the center row of drum storage units.

2. Evaluate new commercially available NDT and/or NDE methods for characterizing the 618-11 burial ground including trenches, drum storage units, and caissons.

3. Improve present radiographic data by inserting a probe sleeve beside selected caissons and drum storage units. This is to inset instrumentation for side-scan X-ray (to get density), gamma count, and possibly provide access for soil and air sampling.

4. Bore into the top of caisson units and insert a video scope to photograph and video the condition of selected caissons. Perform infrared photography and video to ascertain general contents, radiation hot spots; and identify contaminants, such as heat-producing radionuclides like $\mathrm{Pu}-238$.

5. Conduct a gamma count in the caisson selected for the activity in Step 3.

6. Evaluate placing probe sleeves into the trench areas (based on the outcome of Step 2 and conduct exploratory testing suggested in Step 3).

\section{Waste Documentation}

7. More documentation exists in the card files, particularly in individual log books that could provide characterization data for the burial ground. This should be done for 1962-67. 
The following conclusions were made concerning the 618-11 burial ground:

1. Records indicate that the waste generated in the 4.8 years the $618-11$ burial ground was open, contained about five $\mathrm{kg}$ of plutonium. A limited amount of low dose rate plutonium waste went to the 200 West burial grounds for disposal from the 308 and 325 buildings. All other 300 Area waste went to the 618-11 burial ground, including most of the waste from the 325 building and some from the 308 building. The estimate derived from data presented in this document is that 618-11 burial ground drum storage units and caissons have waste containing about five $\mathrm{kg}$ of plutonium plus other TRU radionuclides including slightly enriched uranium. The trenches also contain hundreds of grams to kilogram quantities of plutonium and other fissile material. The TRU curie content, however, is thought to be primarily due to the plutonium concentration.

2. The presence of five $\mathrm{kg}$ of plutonium in the 618-11 burial grounds defines it as a TRU burial ground $(>100 \mathrm{nCi} / \mathrm{g})$ if no correction is made for the soil overburden. If a correction is made for soil overburden of the trenches, the trenches would be considered non-TRU. The drum storage units and caissons would remain TRU waste.

3. Different records show different burial contents. Combined together, the records give a good indication of the burial ground activity.

4. Burial ground contents include defense plutonium, $\mathrm{Pu}^{238}, \mathrm{~Np}^{237}, \mathrm{Am}^{241}$, uranium, thorium, $\mathrm{Pm}^{147}$, radiostrontium and radiocesium, salt cycle molten salt residues, PRTR test fuel pieces, PUREX and REDOX R\&D reprocessing residues, building debris, contaminated casks, lead bricks and shielding, concrete and lead shielded drums, contaminated glassware and columns, contaminated piping, and other equipment including gloveboxes.

5. Categories of waste buried include TRU, non-TRU, contact handled (CH), remote handled (RH), low-level, and mixed-waste. The trenches wastes will contain both $\mathrm{CH}$ and $\mathrm{RH}$ waste. Much of the waste will also be mixed waste, including hazardous chemicals. An effort will need to be made to segregate hazardous materials. Also, equipment and other larger waste containers will probably have to either be cutup or overpacked. Wastes will have to be certified for disposal to the Waste Isolation Pilot Plant. 


\subsection{REFERENCES}

Atlantic Richfield Hanford Company, 1974, "CP-1068 and CP-1069 Burial Ground Fencing," Letter to Al Prince, J. A. Jones Construction Company, Richland, Washington, February 11, 1974

Backman, G. E., P. C. Jerman, R. E. Roberts, and J. W. Vanderbeek, 1963a, "Burial of Hanford Radioactive Wastes," HW-77274, General Electric Company, Richland, Washington, April 15, 1963.

Backman, G. E., 1963', "Plutonium Contamination Waste Disposal", Memo to E A. Berreth, Hanford Atomic Products Operations, Richland, Washington, September 26, 1963.

Backman, G. E., 1964, "Waste Disposal and Decontamination Monthly ReportSeptember 1964, "General Electric Company, Richland, Washington, October 14, 1964.

Baker, E.G., 1968, "Hanford Waste Disposal Summary 1967", BNWL-793, Battelle Northwest Laboratories, Richland, Washington, May 1968.

Battelle-Northwest Laboratories, 1967, "Radioactive Waste Disposal, Pamphlet \#17-667-.5, Battelle-Northwest Laboratories for AEC-RL, Richland, Washington.

Benedict, G. E., K. M. Harmon, G. Jansen, L. K. Mudge, and F. A. Scott, 1963, "Production of Reactor Fuel Oxides from Molten Chloride Salt Solution," HW-SA-2915, General Electric Company, Hanford Atomic Products Operation, Richland, Washington, May 15, 1963.

Bergstrom, K. A., Mitchell, T. H., and Bolin, B. J., 1997, "Geophysical Investigations of the 618-10 and 618-11 Burial Grounds, 300-FF-2 Operable Unit," Document No. BHI-00291, Revision 1, Bechtel Hanford Inc., Richland, Washington, September 1997.

Berreth, E. A., 1962, "325 Building Standard Operating Procedures," HW-73112, General Electric Company, Hanford Atomic Products Operation, Richland, Washington. September 15, 1962.

Berreth, E. A., 1963, "Plutonium Waste," Letter to G. E. Backman, General Electric Company, Hanford Laboratories, Richland, Washington, September 24, 1963. 
Borup, D. R., 1992, "Survey of 618-11," Radiation Survey Report 73085, Westinghouse Hanford Company, Richland, Washington, July 23, 1992.

Bracken, K. W., 1982, "Surface Stabilization Radiation Readings," U.S. Department of Energy, Richland, Washington, October 8, 1992.

Bradley, J. G. and D. E. Clark, 1978, "Waste Generated During Fabrication of Mixed Oxide Nuclear Fuel," HEDL-TME 78-71, Hanford Engineering Development Laboratory, Richland, Washington, October 1978.

Briggs, F. H., 1982, "A Radiological History of HEDL Laboratories and General 300 Area Environs," Draft Document, Hanford Engineering Development Laboratory, Richland, Washington, September 23, 1982.

Brown, D. J., and R. E. Isaacson, 1977, "The Hanford Environment as Related to Radioactive Waste Burial Grounds and Transuranium Waste Storage Facilities," ARH-ST-155, Atlantic Richfield Hanford Company, Richland, Washington, June 1977.

Cadwell, J. J., 1971, "Waste Management Records on In-Soil-Stored Radioactivity," Letter to T. A. Nemzek, with attachment, "In-Soil-Stored Radioactivity in Areas Assigned to HEDL," Hanford Engineering Development Laboratory, Richland, Washington, July $21,1971$.

Conklin, A. W., 1982, "Radiological Surveys of the 618-11 "Y" Burial Ground," Letter to M. A. Christie, No. 72740-82-ESC-047, Rockwell Hanford Company, Richland, Washington, September 29, 1982.

Cooley, C. R., 1975, "Commercial Alpha Waste Program Quarterly Progress Report, January March 1975," HEDL-TME 75-87, Hanford Engineering Development Laboratory, Richland, Washington, October 1975.

Coony, F. M., 1985 "Hanford Defense Waste Environmental Impact Statement Engineering Data Package: Transuranic Pre-1970 Buried Solid Waste Sites," SD-WM-DP-008, Rockwell Hanford Operations, Richland, Washington, August 1985.

Corley, J. P., 1967, "New Silos For High Level Solid Waste," Memo to P. F. X. Dunnigan, Battelle-Northwest Laboratories, Richland, Washington, June 19, 1967. 
Corley, J. P., 1968, "Wye Burial Ground," Memo to W. C. Horton, Battelle-Northwest Laboratories, Richland, Washington, March 12, 1968.

Craddock, L. E., and Gruber, W. J., 1975, "Reduction of Postirradiation Testing Transuranic Waste," Letter to R. B. Hall, Hanford Engineering Development Laboratory, Richland, Washington, February 18, 1975.

DOE/EIS-0113F, 1987, "Final Environmental Impact Statement, Disposal of Hanford Defense High-Level, Transuranic and Tank Wastes, Hanford Site, Richland, Washington," Volume 2, July 1987.

Duncan, D. R., D. A. Burbank, B. C. Anderson, and J. A. Demiter, 1992, "Application of Service Examinations to Transuranic Waste Container Integrity at the Hanford Site," WHC-SA-1450-FP, Westinghouse Hanford Company, Richland, Washington, October 1992.

Geiger, J. F., 1977, "Assessment of Hanford Burial Grounds and Interim TRU Storage," RHO-CD-78, Rockwell Hanford Operations, Richland, Washington, August 1977.

General Electric Company, 1962-1964, "Hanford Laboratories Operation Monthly Activity Reports," Hanford Atomic Products Operation, Richland, Washington, March 1962 December 1964.

Gerber, M. S., 1992, "Past Practices Technical Characterization Study-300 Area-Hanford Site," DOE/RL-92-39, Westinghouse Hanford Company, Richland, Washington, December 1992.

Gift, R. E., "Shipping Casks," HW-76192, General Electric Company, Hanford Atomic Products Operation, Richland, Washington, undated.

Graybeal, R., 1964, "Waste Burial Facility Wye Burial Ground," soil loading calculation and caisson design drawings, January 10, 1964.

Greenhalgh, W. O., 1986, "Technical Studies for the Processing and Disposal of High-Activity TRU Waste, TRU Caisson Waste," HEDL-TC-2861, Hanford Engineering Development Laboratory, Richland, Washington, September 1986.

Greenhalgh, W. O. and J. A. Demiter, 1995, "Letter Report on 618-11 Personnel Interviews," Internal Memo 95105W0G, Westinghouse Hanford Company, Richland, Washington. March 15, 1995. 
Hall, R. B., 1967, "300 Wye Burial Ground," Memo to P. F. X. Dunnigan, Battelle Northwest Laboratory, Richland, Washington, July 31, 1967.

Hall, R. B., 1968, "300 North and 300 Wye Burial Grounds," Memo to L. M. Ostby with Attached Environmental Monitoring Trip Log, Battelle Northwest Laboratory, Richland, Washington, September 16, 1968.

Hall, R. B., 1969, "Hanford Waste Disposal Summary - 1968," BNWL-1081, Battelie Northwest Laboratory, Richland, Washington, May 1969.

HEDL, 1983, "HEDL Postirradiation Examination Capabilities," HEDL-7371, Hanford Engineering Development Laboratory, Richland, Washington, July 1983.

J. A. Jones Construction Company, 1974, "Work Acceptance Form," JAJ-767, Installation of Burial Ground Fencing, J. A. Jones Construction Company, Richland, Washington, July 25, 1974.

Keene, A. R., 1961, "Burial of Solid Wastes in the Vicinity of the 300 Area," Letter to A.J. Stevens, General Electric Company, Hanford Laboratories Operation, Richland, Washington, February 3, 1961.

Keene, A. R., 1963, "Disposal of Wastes Containing Long-lived Radioactive Materials," Memo to F. W. Albaugh, et al., General Electric Company, Hanford Laboratories Operation, Richland, Washington, October 24, 1963.

Kibbe, D. R., 1992, "Subsidence Assessment," Letter to J. M. Nielsen, et. al, No. 87320-92-007, Westinghouse Hanford Company, Richland, Washington, February 19, 1992.

Lust, L. F. and J. W. Davison, 1976, Waste Management Manual, TMT-3, Hanford Engineering Development Laboratory, Richland, Washington, July 1976.

Maxfield, H. L., 1973, "Weekly Check of 300 Area Burial Grounds," Survey No. 11-423, November 28, 1973.

Maxfield, H. L., 1974, "Weekly Check of 300 Area Burial Grounds," Survey No. 11-463, January 24, 1974.

Maxfield, H. L., 1974, "Weekly Check of 300 Area Burial Grounds," Survey No. 11-488, March 1, 1974.

Maxfield, H. L., 1974c, "Weekly Check of 300 Area Burial Grounds," September 4, 1974. 
McCormack, C. G., 1962, "Radioactive Waste Handling at the Hanford Laboratories Radiometallurgy Facility," HW-72103, General Electric Company, Hanford Laboratories Operation, Richland, Washington, January 16, 1962.

McGhan, V. L., 1989, "Hanford Wells," PNL-6907/UC-11, Pacific Northwest Laboratories, Richland, Washington, June 1989.

McGuire, H. E., 1988, "Hanford Site Implementation Plan For The Hanford Defense Waste Environmental Impact Statement Record of Decision," Letter 8851315, Westinghouse Hanford Company, Richland, Washington, February 22, 1988.

Parks, D. L., 1966, "Low Level Solid Waste Disposal Study for Hanford 200 Areas," ISO-169, Isochem, Inc., Richland, Washington, March 15, 1966.

Pauly, T. R., 1990, "Engineering Study for Waste Receiving and Processing (WRAP) Facility, Module 2," WHC-SD-W100-ES-001, Rev. 0, Westinghouse Hanford Company, Richland, Washington, March 28, 1990.

Phillips, S. J., A. E. Reiseauer, W. H. Rickard, G. A Sandness, 1977, "Initial Site Characterization and Evaluation of Radionuclide Contaminated Solid Waste Burial Grounds," BNWL-2184/UC-70, Pacific Northwest Laboratories, Richland, Washington, February 1977.

Phillips, S. J., L. L. Ames, R. E. Fitzner, G. W. Gee, G. A. Sandness, and C. S. Simmons, 1980, "Characterization of the Hanford 300 Area Burial Grounds," PNL-2557 UC-70, Pacific Northwest Laboratories, Richland, Washington, January 1980.

Phillips, S. J., D. D. Fischer, R. C. Crawford, J. L. Rising, 1982, "Engineering Assessment of Low-Level Liquid Waste Disposal Caisson Locations at the 618-11 Burial Ground," WHC-MR-0400, Westinghouse Hanford Company, Richland, Washington, June 1982.

Saueressig, B. J., 1981, "Wye Burial Ground (\#318-11)," Letter to J. L. Deichman, No. 72340-81-045, Rockwell Hanford Company, Richland, Washington, June 9, 1981.

Shirley, G. C., 1981, 1980, "Theoretical Stresses on Buried Waste Containers," WHC-SD-WM-TI-062, Rockwell Hanford Company, Richland, Washington, September 8, 1980.

Smith, F. M., 1965, "Nuclear Safety Specifications as Applied to Dry Storage," Nuclear Safety Specification No. H-1, 327 Building, Battelle-Northwest Laboratories, Richland, Washington, August 18, 1965. 
Stevens, A. J., 1963, Untitled Memo to G. E. Backman, General Electric Company, Hanford Laboratories, Richland, Washington, October 23, 1963.

Voiland, E. E., 1970, "Waste Burial Ground Data Pacific Northwest Laboratory Sites," Letter to F. S. Zvonar, Battelle-Northwest Laboratories, Richland, Washington, February 2, 1970.

Wendling, M. A., 1993, "618-11 Burial Ground USRADS Radiological Surveys," Westinghouse Hanford Company, Richland, Washington, February 1993.

Westinghouse Hanford Company, 1983, "1983 Site Assessment," WHC-SD-PRS-004, 1983, Rev. Letter 0-0, Page A-27.

Wittenbrock, N. G., P. C. Walkup, and J. K. Anderson, 1959, "Plutonium Recycle Test Reactor Final Safeguards Analysis," HW-61236, General Electric Company, Richland, Washington, October 1, 1959.

Wittenbrock, N. G., 1967, "Plutonium Handling Safety in the Plutonium Recycle Program," BNWL-SA-1345, Battelle-Northwest Laboratories, Richland, Washington, July 3, 1967. 
HNF-EP-0649, Rev. 0

ENCLOSURE

\section{APPENDIX A}

WASTE SHIPPED FROM THE 325-A CELLS 1961-1967 (EXTRACTED FROM PNL 325-A SHIFT LOGBOOKS) 


\section{APPENDIX-A}

- WASTE SHIPPED FROM 325-A HOT CELLS, 1961-1967 (EXTRACTED FROM PNL 325-A SHIFT LOGBOOKS)

The 325-A hot cell started up hot in June 30, 1960 with 1Wh feed solution in B-cell, and solid waste was removed from the cells starting April 5, 1961.

$\underline{1961}$

04/06/61 Work in A-cell with PUREX Sr 90. Removed (2) 55-gallon drums of solid waste. Each 55-gallon drum will only contain 3 one-gallon cans. Most of the cans will contain: crushed glass, rags, paper, metal, and plàstic.

04/07/61 (2) $1^{\text {"I }}$ lead-lined 55-gallon drums from $A$ and $B$ cells.

04/11/61 3 waste boxes with plastic, rags, paper, tubing, one box reading $1 R / h r$.

06/02/61 4 waste boxes waste from A-cel1, manipulator boots, polytubing, 1 gai. cans of waste, one reading $500 \mathrm{mr} / \mathrm{hr}$, and one reading $3.5 \mathrm{R} / \mathrm{hr}$.

$06 / 20 / 61$ Waste from $A$ and $B$ cells into (1) $1^{11} 55$-gallon and (1) 2" 55-gat7on drum.

09/11/61 B-cell waste 2 - 2" lead 55-gallon and 3-1" lead 55-gallon drums. Glass filters, sample vials, rags, and metal. IWW wash.

$10 / 06 / 61$ (4) culvert 55-gallon drums from A-cell.

10/09/61 9 CWS filters were removed from cell exhaust.

10/26/61 1 small glove box in wood box, Photo. 061541-1.

11/01/61 A-cell waste (2) culvert 55-gallon and (1) 1" lead drums (Sr ${ }^{90}$ ).

11/11/61 8-cell waste (2) 1" lead and (3) 2" lead 55-galion drums.

$11 / 28 / 61 \cdot C$-cell waste (2) 1" lead inserts 55-galion drums.

$12 / 20 / 61 \quad A-c e l l$ waste (1) 55-gallon drum reading $2 R / h r$ though side.

12/22/61 A-cell waste (1) 55-gallon drum: Tc, $\mathrm{Pm}, \mathrm{Sr}$, and Am.

1962

01/09/62 B-cell waste (3) 1" lead 55-gallon drums.

01/12/62 B-cell CWS filter.

$01 / 24 / 62$ (1) culvert 55-gallon drum from $C$-cell. 
02/20/62 A-cell waste (3) culvert 55-gailon drums (sample vials, glass, rags). 02/21/62 A-cell waste SST tubing, fitting, valves. (1) 55-gallon drum.

02/23/62 A-cell waste (1) I" lead drum and (2) culvert drums.

02/26/62 A-cell waste (1) 1" lead drum and (1) culvert drum.

03/1/62 A-cell (1) 15-gailon Black iron can.

03/14/62 B-cell CWS filter $\mathrm{Sr}^{90}$.

03/22/62 A-cel1 (1) 55-gailon drum containing SST items and lead brick.

03/23/62 A-ce11 TK-7 and (1) 55-gallon drum with SST items.

$03 / 28 / 62$ A-cell shipped (3) boxes containing glass pipes $4^{\prime \prime} O D \times 9^{\prime} L$ and (2) 55-gallon drums of small metal parts, valves and tubing.

$03 / 29 / 62$ (3) box containing glass pipes. $6^{\prime \prime} 00 \times 9^{\prime}$ long and (1) $4^{\prime} \times 4^{\prime} \times 8^{\prime}$ box metal rakes, tanks, tubing, and (2) 55-gallon drums of junk.

$04 / 02 / 62$ (2) $4^{\prime} \times 4^{\prime} \times 8^{\prime}$ wood boxes of metal equipment, (2) 30-gation drums with lead and (3) 5 -gallon buckets with lead.

$04 / 04 / 62$ (11) wood boxes $8^{\prime \prime} \times 20^{\prime \prime} \times 28^{\prime \prime}$. with lead bricks.

$04 / 06 / 62$ (3) 20 -gallon tanks and (6) boxes of lead.

$04 / 10 / 62$ (8) boxes of lead bricks and (1) 55-gallon drum (1) wood box of junk $30^{\prime \prime}$ $\times 30^{\prime \prime} \times 35^{\prime \prime}$.

$05 / 21 / 62$ (3) culvert drums of waste from B-cel1, glass, rags, plastic. The work was with lWW feed from PUREX process.

09/04/62 Sent (14) C.W.S. filters to burial ground. Three of them were from Bcell reading $60 \mathrm{R} / \mathrm{hr}, 40 \mathrm{R} / \mathrm{hr}$, and $80 \mathrm{R} / \mathrm{hr}\left(\mathrm{Sr}^{90}\right)$.

$09 / 24 / 62$ (1) 55-galion drum with $1^{\prime \prime}$ lead lined ( $\mathrm{UO}_{2}, \mathrm{PuO}_{2}$ works in $\mathrm{C}$-cel1).

10/03/62 (1) A-cel1 C.W.S. filter, (1WW spray calciner work).

10/09/62 (1) A-cell C.W.S. filter.

10/25/62 C-cel1 waste (1) I" lead, (1) culvert 55-gallon drum (4R/hr at bottom of drum) and three 5-gallon buckets.

10/26/62 (1) A-cell C.W.S. filter.

10/29/62 A-cell C.H.S. filter $(60 \mathrm{R} / \mathrm{hr})$.

10/31/62 A-cell C.W.S, filter. 
11/01/62 C-cell (2) 1" lead drums and (2) culvert 55-gallon drums containing SST valves, fittings, tubing, glass, and plastic.

11/02/62 C-cell waste (3) culvert 55-gallon drums $\left(\mathrm{UO}_{2}, \mathrm{PuO}_{2}\right.$ work).

11/2-5/62 (2) C.M.S. filters from A-cell (one at $70 \mathrm{R} / \mathrm{hr}$ and one at 100R/hr).

$11 / 05 / 62$ (2) 1 " lead drums from C-cell waste.

11/07/62 A-cell C.H.S. fi]ter.

11/29/62 C-cell equipment removal (1) $4^{\prime} \times 4^{\prime} \times 8^{\prime}$ wood box and (2) 55-gallon drums.

12/03/62 C-cell (1) $4^{\prime} \times 4^{\prime} \times 8^{\prime}$ wood box and (1) 55-galion drum.

12/05/62 A-cell C.W.S. filter reading 400R/hr.

$12 / 12 / 62$ Removed (4) waste cartons from room 603 reading up to $4 \mathrm{R} / \mathrm{hr}$.

$\underline{1963}$

01/14/63 (2) culvert 55-gallon drum from A-cell.

01/25/63 B-ce11 (2) 1" lead 55-gallon drums.

02/08/63 C-cell (2) culvert 55-gallon drums.

B-cell (2) I" lead and (2) 2" lead drums.

02/11/63 (3) culvert and (3) 1 ". lead 55-gallon drums ( $A$-ce11 1 WW waste)

(3) C.W.S. filters, 2 from A-cell, 1 from B-cell.

02/12/63 (2) culvert drums from A-cel1.

$02 / 13 / 63$ (1) culvert drum from A-cell and (1) 1" lead drum.

02/15/63 We received 50,000 curies of $5 r^{90}$, put into B-cell.

03/26/63 (2) culverts C-cell and (1) culvert A-cell (Pm in C-cell).

04/18/63 Removed equipment from C-cell Pm contaminated put in a $3^{\prime} \times 3^{\prime} \times 6^{\prime}$ wood box.

04/19/63 Removed 7 C.H.S. filters from cells exhaust.

04/23/63 Removed all equipment from C-cell (Pm work): glass pipes, tanks, trays, tables, tubing, valves. Put into 3 boxes $4^{\prime} \times 4^{\prime} \times 8^{\prime}$.

05/01/63 B-cell waste (1) 2" lead, (1) culvert 55-gallon drum.

05/02/63 A-cell (1) I" lead, (1) culvert 55-gallon drum, 3" lined 55-galion drum contains (2) $8^{\prime \prime} \times 8^{\prime \prime} \times 6^{\prime \prime}$ C.H.S. filters from calciner off gas and vacuum lines and other material. 
$05 / 07 / 63$

(2) 1" lead lined 55-gallon drums, contains SST tubing, valves plastic, (1) 2" lead lined 55-gallon drum contains C.W.S. filter from B-cell vacuum system $\left(8^{\prime \prime} \times 8^{\prime \prime} \times 6^{\prime \prime}\right)$.

06/20/63 A-cell C.W.S. filter (exhaust).

07/15/63 A-cell (2) culvert 55-gallon drums, containing sample bottles, rags, metal, and plastics.

08/13/63 B-cell waste (3) 1" lead and (1) 2" lead 55-gallon drums of waste: glass sample vials, bottles, rags, and plastic.

09/06/63 A-cell C.W.S. filter.

10/16/63 A-cell (3) 1" lead, (3) culverts, and (1) 2" Jead 55-galion drums.

10/23/63 A-cell C.W.S: filter.

11/04/63 A-cel1 C.W.S. filter reading $30 \mathrm{R} / \mathrm{hr}$.

11/15/63 A-ce11 (2) 1" lead, (1) 2" lead, (3) culvert 55-gallon drums.

$11 / 22 / 63$ A-cell (2) C.H.S. filters, reading on one was $2.7 \mathrm{R} / \mathrm{hr}$ and the other $22 \mathrm{R} / \mathrm{hr}$. They were put into load lugger, then to burial ground:

11/27/63 C-cell Pu waste in one-galion cans put in waste box.

12/02/63 A-cell C.W.S. filter reading $1 R / \mathrm{hr}$.

12/03/63 A-cell C.W.S. filters reading $3 R / h r$ and $5 R / h r$.

12/12/63 A-cell C.H.S. filters reading 1 WW spray calciner work.

12/16/63 A-cell C.W.S. filters.

12/17/63 A-ce11 C.W.S. filters reading 70R/hr.

12/20/63 A-cell C.H.S. filters.

12/23/63 A-cell C.H.S. filters.

$\underline{1964}$

01/03/64 Pulled 10 C.W.S. filter.

$01 / 03 / 64$ (6) one-gallon cans from $A-c e 11$, using the new 1 ton cask.

01/08/64 (3) one-gallon cans C-cel1, Pu waste.

01/09/64 (6.) one-gallon cans C-cell.

02/04/64 (11) one-gallon cans from $A$ and $B$ cells.

02/28/64 A-cell C.W.S. filter. 
03/06/64 B-cell waste into 15-gallon black iron can using the new 7 ton waste cask.

03/11/64 C-cell (1) 15-gallon. can ( $\mathrm{Pu}, \mathrm{UO}_{2}$, work).

03/16/64 A-cell C.W.S. filter (150R/hr).

$03 / 18 / 64 \quad C$-cell two 15-galion cans waste.

03/19/64 A-cell (6) one-galton cans.

03/26/64 C-cell one 15-gallon can and (6) one-gallon cans.

03/31/64 A and B cell, (12) one-gallon cans.

04/14/64 C-cell (3) one-galton and (1) 15-gallon cans.

04/15/64 A-cell C.W.S. filter.

04/30/64 C-cell (1) 15-galion can.

05/04/64 C-cell C.W.S. filter $\left(\mathrm{UO}_{2}\right)$.

05/28/64 A-cell (9) one-gallon cans $\left(\mathrm{Sr}^{90}, \mathrm{Ce}\right)$.

06/02/64 C.W.S. filters from $A, B$, and $C$ cells (3).

06/03/64 Waste from $A, B$, and $C$ cells (12) one-gallon cans.

06/11/64 C-cel1 C.W.S. filter $\left(\mathrm{UO}_{2}\right.$ dust) changed out the C.H.S. filter on $\mathrm{C}$ for the second time ( 2 filters), one reading $80 \mathrm{R} / \mathrm{hr}$. Changed C.W.S. filters on $A$ and $B$ cells ( 2 filters), one reading $90 \mathrm{R} / \mathrm{hr}$.

06/12/64 C-cell C.W.S. filter (reading $80 \mathrm{R} / \mathrm{hr}$ ) decladding fuel rods.

06/15/64 (8) C.H.S. filters changed out.

$06 / 19 / 64 \quad$ (2) $A$ and $B$ cell filter changed out.

06/22/64 A-cell waste (6) one-gallon cans and (2) 15-gallon container with calcined IWW from PUREX.

06/23/69 (12) one-galion cans and 4 containers with calcined pots of 1 WW waste.

06/23/64 C-cell C.H.S. filter change.

06/24/64 A-cell (2) calciner pots and (6) one-gallon cans.

06/25/64 A-cell (4) caiciner pots.

06/26/64 (2) C.W.S. filters from $B$ and $C$ cell.

06/29/64 A-cell waste (2) 15-gallon cans.

06/30/64 A-cell (2) 5-galion buckets and (1) 15-galion can. 
07/10/64 C-cell C.H.S. filters.

$07 / 14 / 64$ (2) 5-gallon cans from A-cell and (2) 5-gallon cans from C-cell contain carbon electrodes from Pu work.

07/15/64 A-cell (8) one-galion cans.

07/21/64 C-ce11 C.W.S. filters.

$07 / 30 / 64$ (2) 5-galion cans A-ce11, (2) 5-galion cans B-ce11, (3) one-gallon cans c-cell.

07/31/64 C-cell C.W.S. filter.

08/14/64 C-ce]1 C.W.S. filter $\left(\mathrm{Pu}^{\mathrm{U}} \mathrm{UO}_{2}\right)$.

$08 / 17 / 64$ C-cell (4) 5-galton cans.

09/03/64 C-cell (2) 5-gallon cans, B-cell (2) 5-gallon cans.

09/09/64 (2) C.W.S. filters.

$09 / 10 / 64$ (2) 5-gallon cans A-cell, (2) 5 -gallon cans from B-cell, and (2) 5-gallon cans from $\mathrm{C}-\mathrm{cel} 1$.

$09 / 21 / 64 \quad A$ and $C-c e 11$ C.W.S. filters.

09/22/64 B-cell C.W.S. filter (thorjum work in ce11).

10/06/64 C-cell (4) 5-gallon cans and (6) one-gallon cans.

10/07/64 A and B cell C.H.S. filters (2).

10/08/64 B-cell (2) 5-gallon cans and (3) one-galion.

10/15/64 A and C cell C.H.S. filters (2).

$10 / 22 / 64: B$ and $C$ cell C.W.S. filters (2).

11/01/64 Solution came out under C-cell door it was cleaned up with absorbent and rags. Put waste into (4) waste boxes, they were reading $(4 R / h r)$.

11/04/64 C-ce11 C.H.S. filters (2).

$11 / 05 / 64$ C-cell C.H.S. filter (1). (6) one-gallon and (4) 5-gallon cans.

11/9-30/64 There were (12) C.W.S. filter change outs on the fuel decladding operation in $\mathrm{C}$-cell.

$12 / 02 / 64$ (2) 5-gailon cans from B-cell, (1) 15-gallon and (6) one-gallon from C-cel1.

12/03/64 (2) 5-gallon cans B-cell and (1) 15-gallon can C-cell.

12/14/64 (5) C.H.S. filters from C-cell work. 
01/05/65 A-cell (2) 5-gallon cans.

01/05/65 $A$ and B-cel1 (6) 5-gallon cans.

01/08/65 Changed out all C.W.S. filters, (10) in ail.

$01 / 12 / 65-$ $02 / 25 / 65$

Starting A-cell clean out of the spray calciner equipment. There were (37) 15-gallon containers with cut up SST items, calciner, rakes, valves, pumps, air motors, $8^{\prime \prime} \times 8^{\prime \prime} \times 6^{\prime \prime}$ C.W.S. filters, and calcined IWW pots.

03/02/65 C-cell C.W.S. fi]ter (2).

03/04/65 C-cell C.W.S. filter (1) reading 70R/hr.

03/09/65 Several 30-gallon drums containing lead bricks from A-cell.

$03 / 10 / 65 \quad$ (8) C.W.S. filters.

$03 / 10 / 65$

$04 / 01 / 65$

(17) wood boxes $4^{\prime} \times 4^{\prime} \times 8^{\prime}$ containing tanks, trays, dunnage, and insulation

$03 / 31 / 65$

(3) C.H.S. filters.

$04 / 06 / 65$

(1) C.W.S. filter C-cell.

$04 / 12 / 65$

(2) one-gallon cans C-cel1.

$04 / 14-30 / 65$

(6) 15-gallon cans and (3) one-gallon cans B-cell.

$05 / 05 / 65$

(1) C.W.S. filter C-cell.

$05 / 11 / 65$

(2) $2^{\prime} \times 3^{\prime} \times 4^{\prime}$ wood boxes of B-cell equipment: large press, one oven and one tube furnace.

$05 / 25 / 65$

(1) C.W.S.filter C-cell.

$06 / 16 / 65$

(4) 5-gallon cans from $\mathrm{C}$-cell $\mathrm{Pu}, \mathrm{UO}_{2}$ work.

$06 / 23 / 65$

(2) C.H.S. filters C-cell.

$07 / 22 / 65-$

$10 / 21 / 65$

(50) 15-gallon Black iron cans containing C-cell equipment removed: glass, stainless steel vaives, tubing, rakes, condensers, small tanks, pumps, rotometers, and (4) C.W.S. filters.

$10 / 27 / 65$

(6) 5-gallon buckets from B-cell.

$11 / 03 / 65$

(6) wood boxes $4^{\prime} \times 4^{\prime} \times 8^{\prime}$ containing large tanks, trays, tubing, tools, skill saw, and wrenches. 
$11 / 10 / 65 \quad$ (1) C.W.S. filter C-cell.

$11 / 22 / 65$ (2) 5-gallon cans from B-cell.

$11 / 24 / 65 \quad$ (2) $4^{\prime} \times 4^{\prime} \times 8^{\prime}$ wood boxes containing the C-cell crane and parts, and miscellaneous junk.

$12 / 09 / 65$, (3) C.H.S. filter.

$12 / 13 / 65 \quad$ (2) 5-galion cans B-cell.

$\underline{1966}$

$03 / 07 / 66 \quad$ (1) 5-gallon can C-cel1 $\mathrm{Pm}^{147}$ oxide work.

$03 / 14 / 66$

(2) 15-gallon SST resin cans from A-cell $\mathrm{Pm}^{147}$.

$03 / 15 / 66$

(4) 5-gallon cans B-cell.

$03 / 29 / 66$

(2) 5-gallon cans and (1) 15-gallon can from A-cell.

$03 / 30 / 66$

(3) 15-gallon cans into (1) large container A-ceil.

$04 / 12 / 66$

(4) 5-galion cans from A-cell Pm work.

$04 / 15 / 66$

(1) $4 \times 4 \times 8$ foot wood box with trays, press, and stands from Pm work.

$05 / 11 / 65$

(3) C.W.S. filters.

$05 / 20 / 66$

(2) 5-gallon cans and (1) 15-gallon resin can from Pm work.

$06 / 03 / 66$

(3) C.H.S. filters.

$06 / 20 / 66$

(6) 5-gallon cans glass, poly tubing, valves, rags, and plastic.

$06 / 21 / 66$

(4) 15-galion BTack iron cans. A-cell waste.

$08 / 30 / 66$

(4) 5-galion cans.

$09 / 15 / 66$

(4) 15-gallon SST resin cans.

$09 / 16 / 66$

(2) 15-gallon Black Iron cans.

$09 / 27 / 66$

(4) 5-gaition cans.

$09 / 28 / 66$

(4) 5-gallon cans from A-cell.

$11 / 02 / 66$

(6) 5-gallon cans B-cell $5 r^{90}, \mathrm{Ce}, \mathrm{Cs}$.

$11 / 14 / 66$

(4) 40-gallon tanks from room $40 \mathrm{~A}$.

$11 / 23 / 66$

(4) 15-gallon resin cans from A-cell.

$12 / 13 / 66$

(6) 5-gallon cans from C-cell Np (Neptunium) work. 
$01 / 06 / 67$

$01 / 13 / 67$

$02 / 08 / 67$

$02 / 09 / 67$

$02 / 17 / 67$

$03 / 17 / 67$

$03 / 20 / 67$

$03 / 21 / 67$

$03 / 27 / 67$

$03 / 31 / 67$

04/03/67

$04 / 7-11 / 67$

$04 / 19 / 67$

$05 / 04 / 67$

05/05/67

$06 / 13 / 67$

$06 / 28 / 67$

$07 / 06 / 67$

$07 / 20 / 67$

$07 / 24 / 67$

$07 / 26 / 57$

$08 / 09 / 67$

$08 / 18 / 67$

$09 / 13 / 67$

$09 / 14 / 57$

(3) C.W.S. filters reading $500 R / h$.

(2) 5-gallon cans from B-cell and (4) 5-gallon cans from A-cell.

(2) 5-gallon cans from C-cell and (4) 5-gallon cans from B-cell.

(10) C.W.S. filters.

(2) 5-gallon cans and (1) 15-gallon resin can.

(4) 5-gallon cans and (1) 15-gallon resin can.

(4) 5-gallon cans from A-cell Pr work.

(1) C.W.S. filter from B-cell Np work.

(2) C.W.S. filters from C-cell and one C.W.S. filter with charcoal for iodine.

(7) 15-gallon resin cans from A-cell Pm work.

(3) 15-gallon Black Iron cans.

(18) 5-gallon cans C-cell.

(2) 5-gallon cans from 8-cell Np work and (1) 15-gallon A-cell Pm waste can.

(2) wood boxes containing glass pipe, $16^{\prime \prime} O D \times 9^{\prime}$, and $8^{\prime \prime} O D \times 9^{\prime}$ long.

(2) 5-gallon glass containers with resin and 55-gallon drum with absorbing compound and vacuum pump oil.

(14) 5-gallon cans $B$ and $C$ cells.

Waste cartons that contained rags with $\mathrm{Pu}^{238}$, wipes from spill in room 603.

(9) C.H.S. filters.

(6) 5-galton cans from $C$-cell.

(6) 5-gallon cans from B-cell.

(1) $4^{\prime} \times 4^{\prime} \times 8^{\prime}$ wood box contains lumber, plastic, and rags.

(4) 5-gallon cans from $B$ and $C$ cell.

(3) C.W.S. filters vault exhaust reading $1.5 \mathrm{R} / \mathrm{hr}, 9 \mathrm{R} / \mathrm{hr}$, and $4 \mathrm{R} / \mathrm{hr}$.

(8) 15-gallon resin cans and (2) 5-gallon cans from A-cell.

(8) 5-gallon cans from Pm work. 
$09 / 15 / 67$

(6) 5-galion cans from Pu work.

$10 / 18 / 67$

(6) 5-gallon cans from A-cell Pm and (1) 15-gallon resin can.

$10 / 19 / 67$

(8) 5-gallon cans from A-cell.

$10 / 26 / 67$

(8) 5-gation cans from $\mathrm{C}$-cell.

$11 / 03 / 67$

(3) $4^{\prime} \times 4^{\prime} \times 8^{\prime \prime}$ wood boxes, equipment from A-cel1: glass column, metal, wood, and plastic.

$11 / 17 / 67$ (1) $4^{\prime} \times 4^{\prime} \times 8^{\prime}$ wood box contains $3 / 4^{\prime \prime}$ plywood used as shielding, lead, plastic, rags, and $2^{13} \times 4^{\prime \prime} s$.

$11 / 20 / 67$

(4) 5-gallon cans from $C-c e 11$.

$11 / 21 / 67$

(3) 15-gallon resin cans from A-cell and (2) 5-galion cans from C-cell.

$11 / 22 / 67$

(2) 5-gallon cans from $\mathrm{C}$-cell.

$12 / 12 / 67$

(3) 15-gallon resin cans from A-cell.

$12 / 14 / 67$

(6) 5-gallon cans from A-cell.

$12 / 22 / 67$

(3) 15-gallon resin cans.

$12 / 27 / 67$

(12) 5-galion cans from A-cell and (one) resin can.

$12 / 29 / 67$

(4) 5-gallon cans from $B$ and $C$ cells. 
HNF-EP-0649, Rev. 0 ENCLOSURE

\section{APPENDIX B}

DRAWING H-3-9951, "PLOT PLAN 300 WYE BURIAL GROUND" Revisions 2-7

DRAWING H-6-930, "PLOT PLAN 300 WYE BURIAL GROUND" Rev. 0 


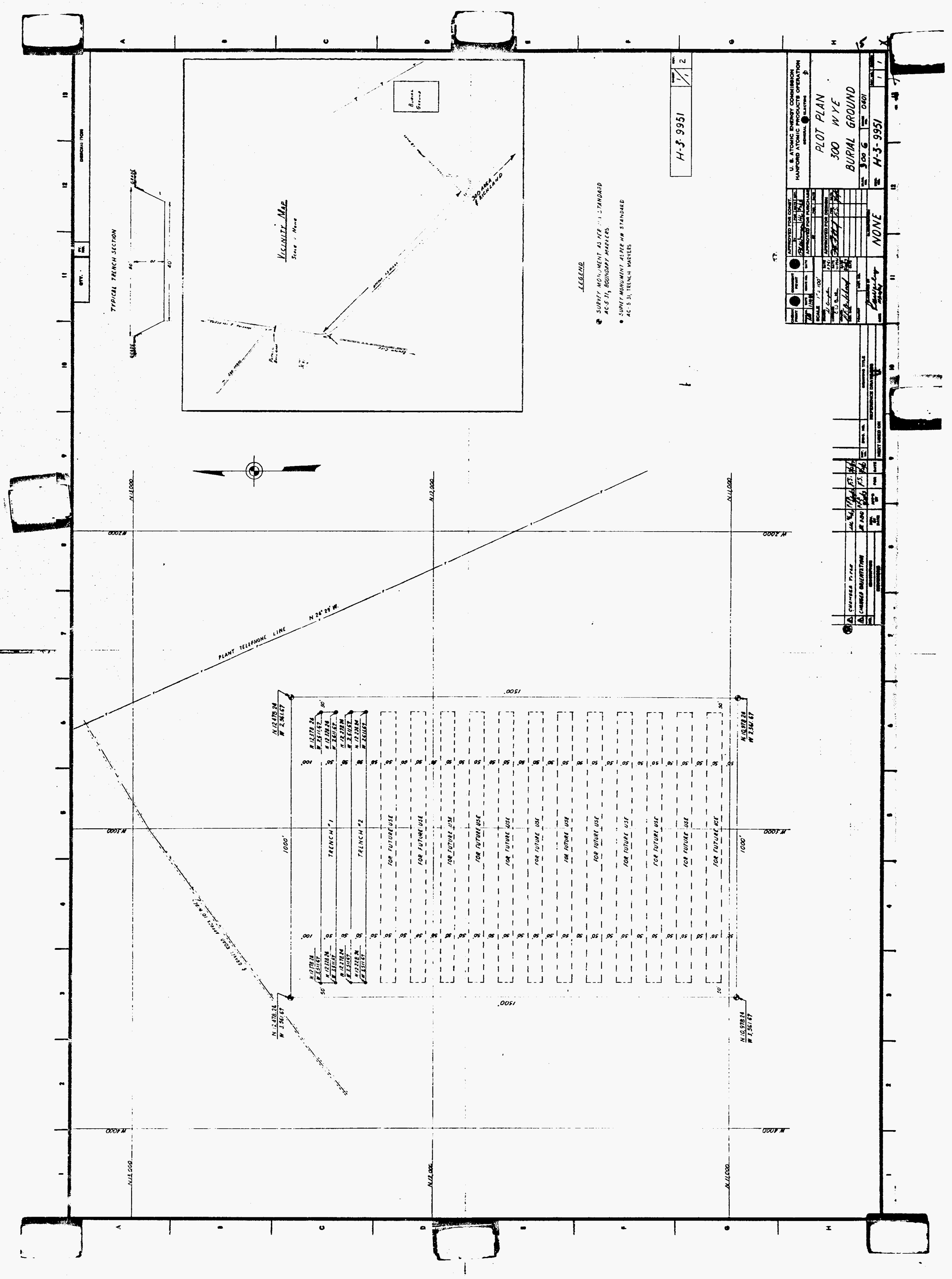




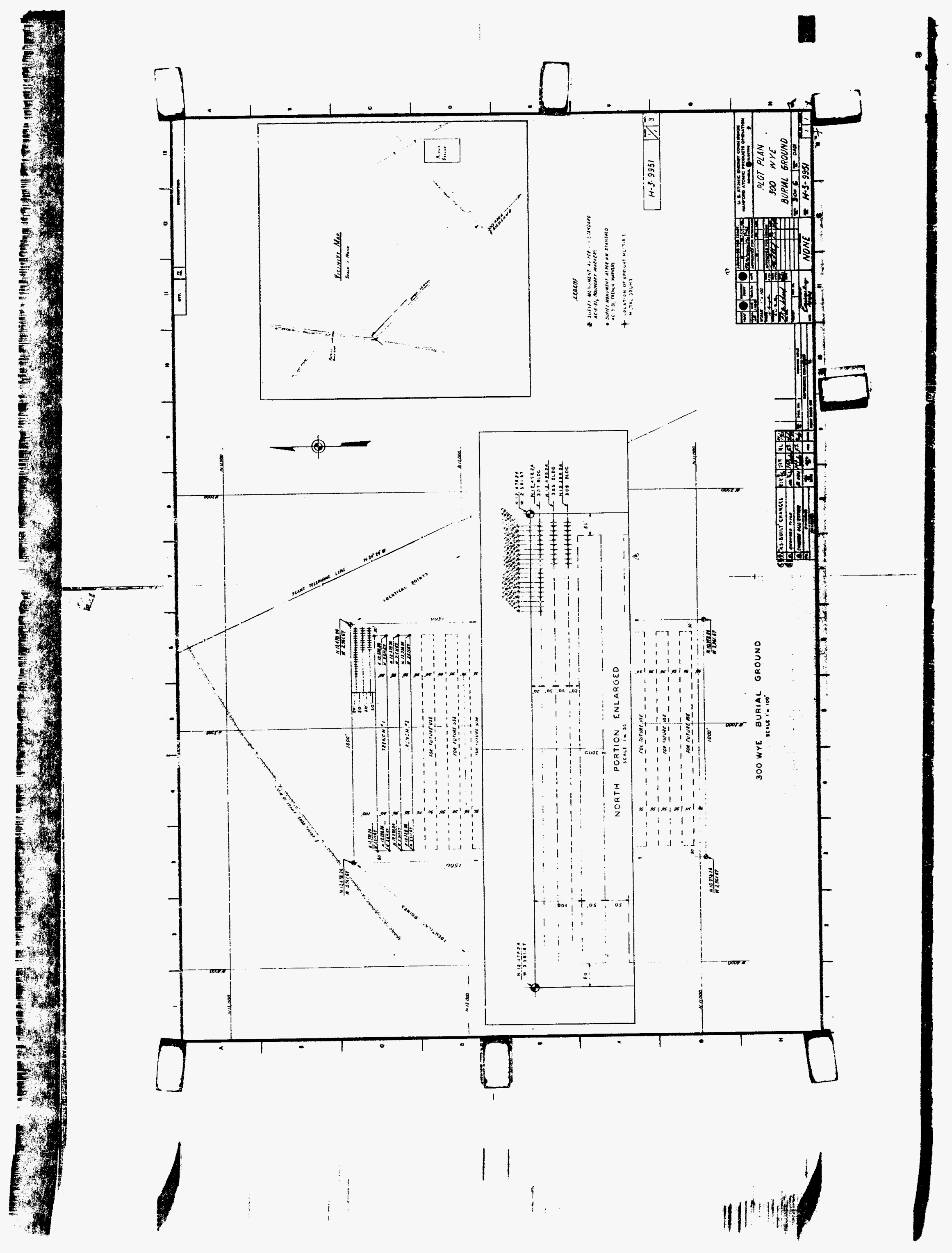




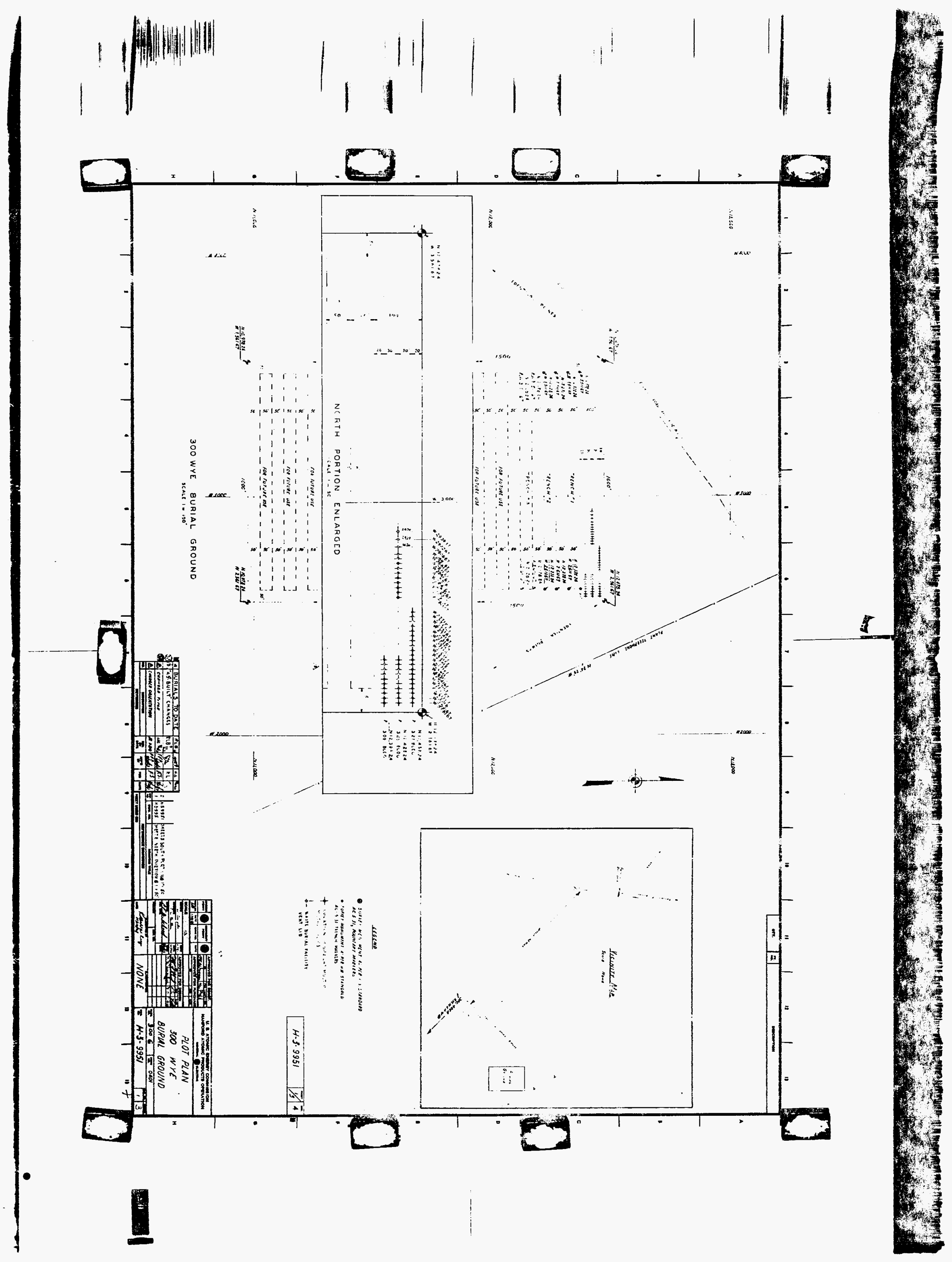




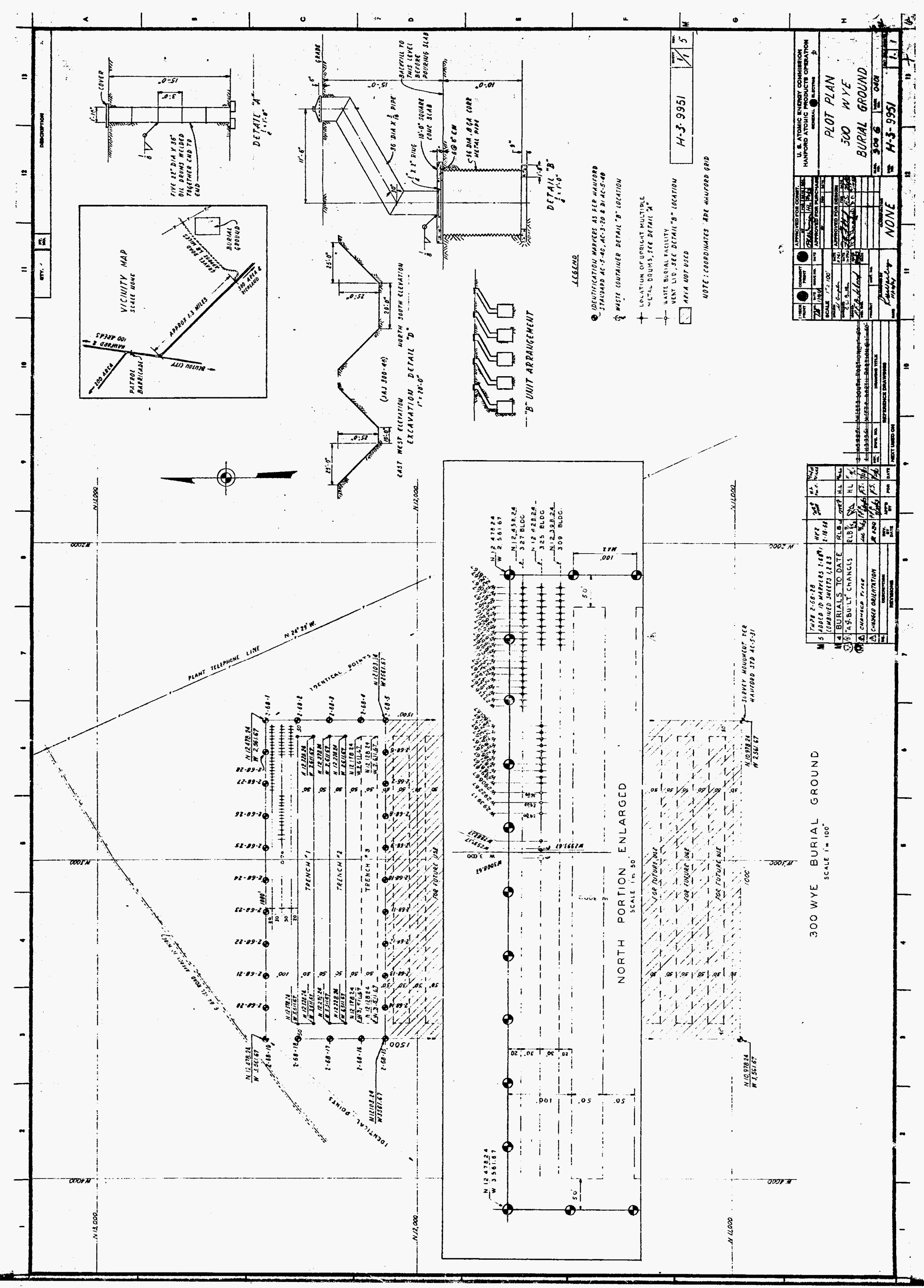




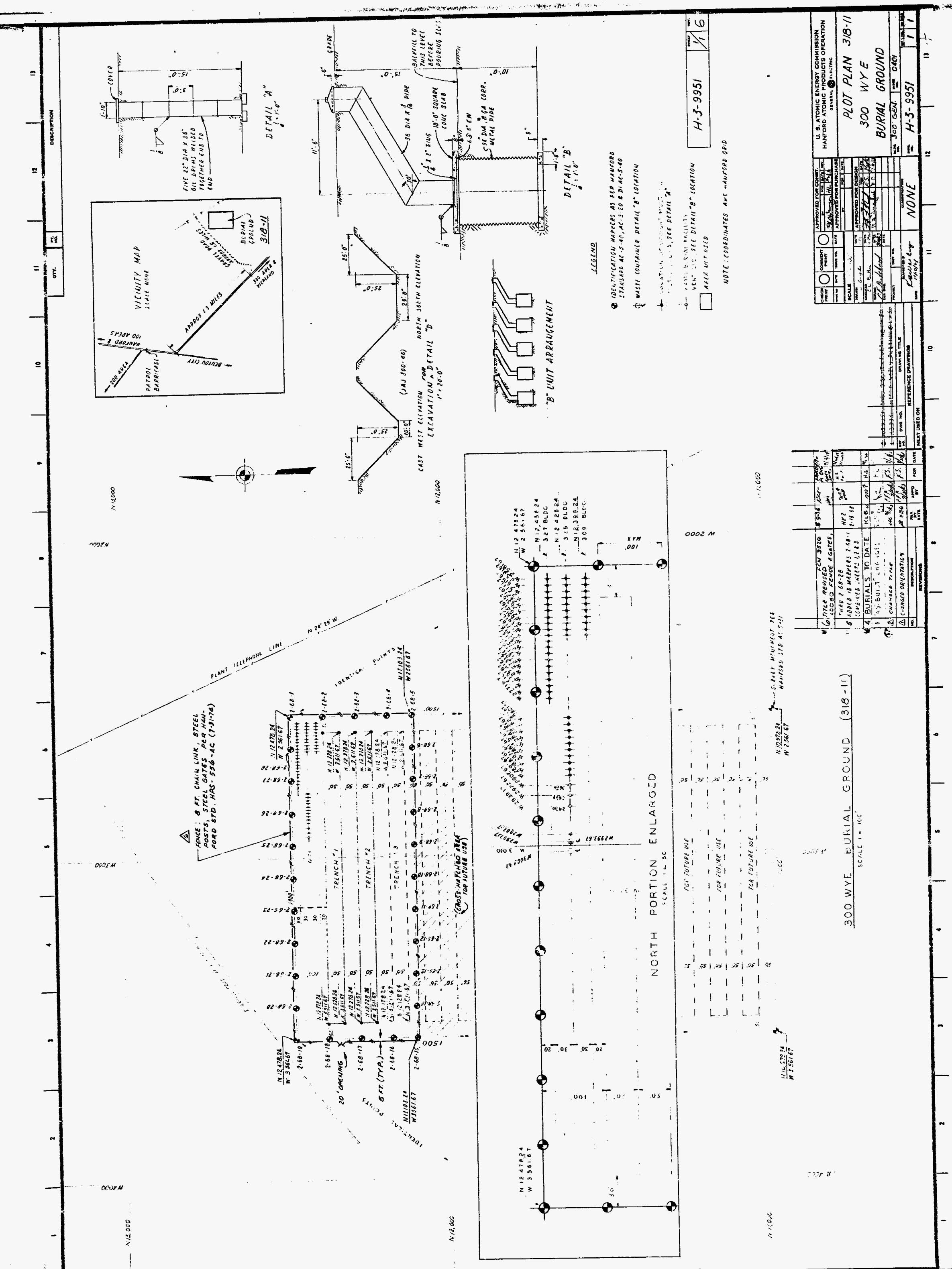




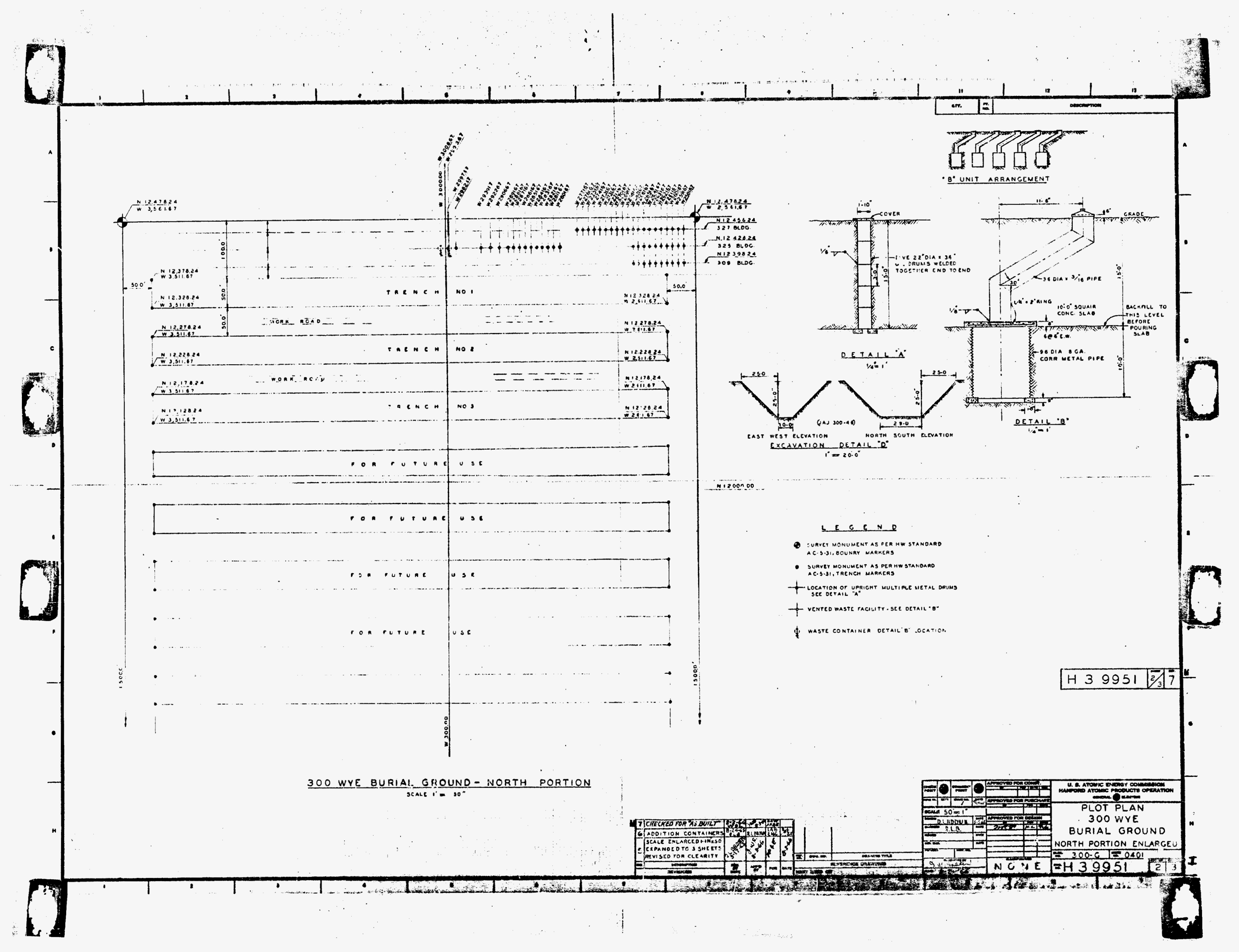




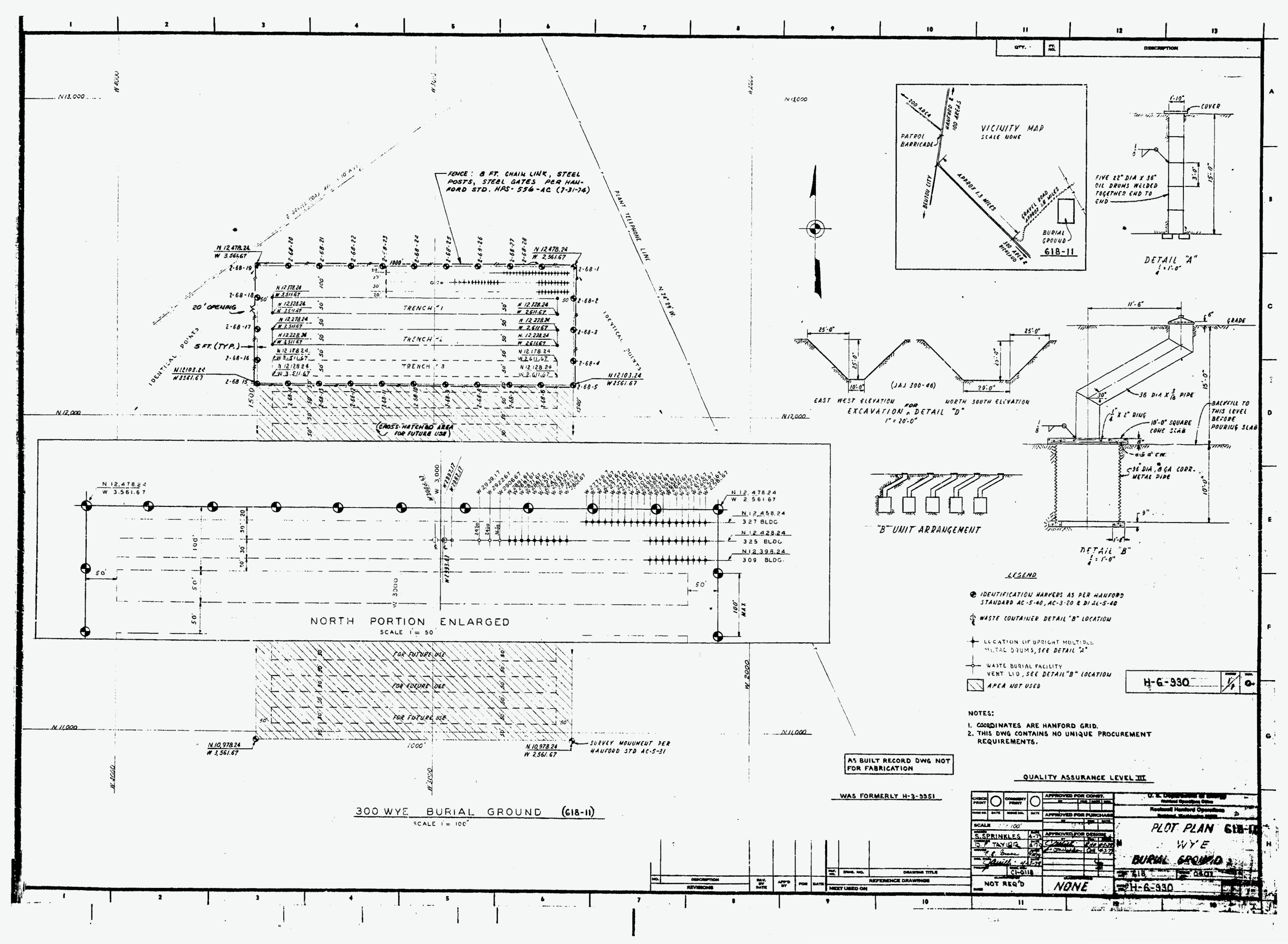


HNF-EP-0649, Rev. 0

ENCLOSURE

\section{APPENDIX C}

HANDBOOK OF SHIPPING CONTAINERS, HEDL MG-104

PAGES $1,3,5,7,9,15,23$, and 27

and

CASK PHOTOGRAPHS 0640160-3, and 0640160-1 


\begin{tabular}{|c|c|}
\hline $\begin{array}{l}\text { Revision } \\
4\end{array}$ & $\begin{array}{ll}\text { Paget } & 1 \\
& 1\end{array}$ \\
\hline DECE & ER 30,1983 \\
\hline
\end{tabular}

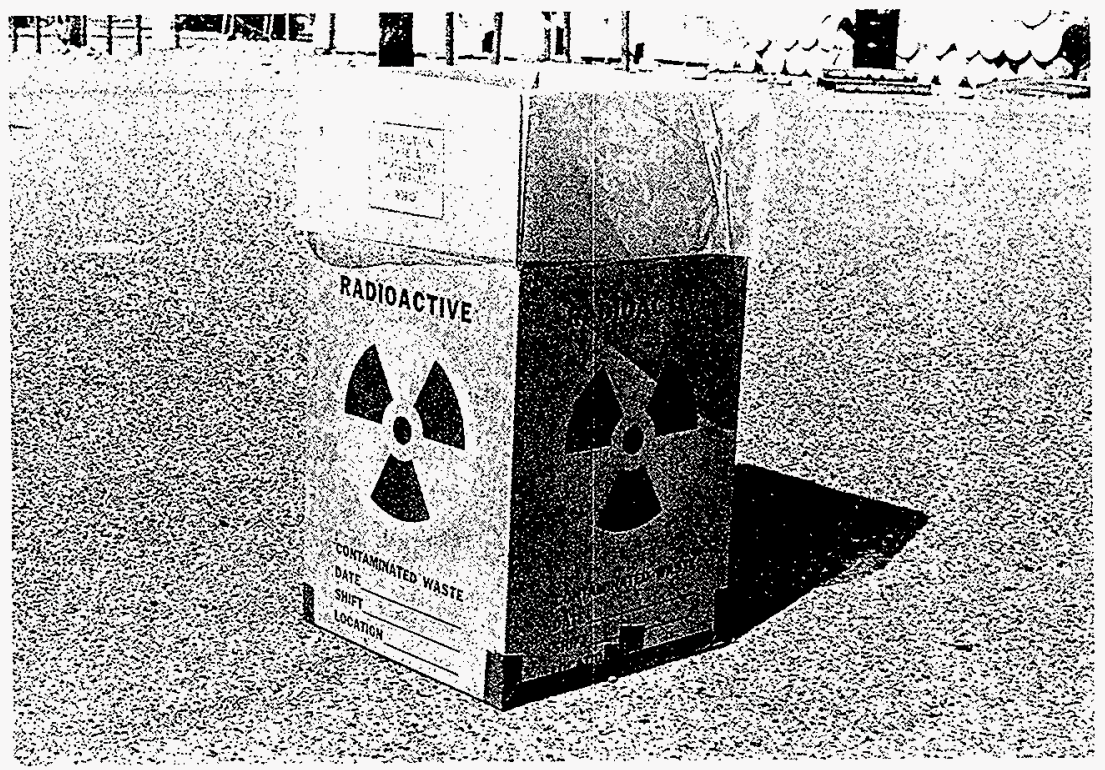

1. COMMON NAME: Waste carton

2. OFFICIAL NAME: Carton, corrugated, radioactive

3. CONTAINER EXTERIOR DIMENSIONS: $15^{\prime \prime} \times 16^{\prime \prime} \times 16^{\prime \prime}$ and $18^{\prime \prime} \times 18^{\prime \prime} \times 24^{\prime \prime}$

INTERIOR DIMENSIONS: $215^{\prime \prime} \times 16^{\prime \prime} \times 16^{\prime \prime}$ and $278^{\prime \prime} \times 18^{\prime \prime} \times 24^{\prime \prime}$

EMPTY WEIGHT: N/A MAXIMUM GROSS WEIGHT: 65 pounds

SHIELDING MATERIAL: NONE THICKNESS: N/A

DESCRIPTION

DRAWING NO.

Ready to assemble cardboard cartons.

FOR INFORMATION CONTACT: Available from Rockwell stores, Caption 42.

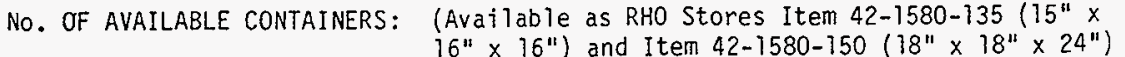




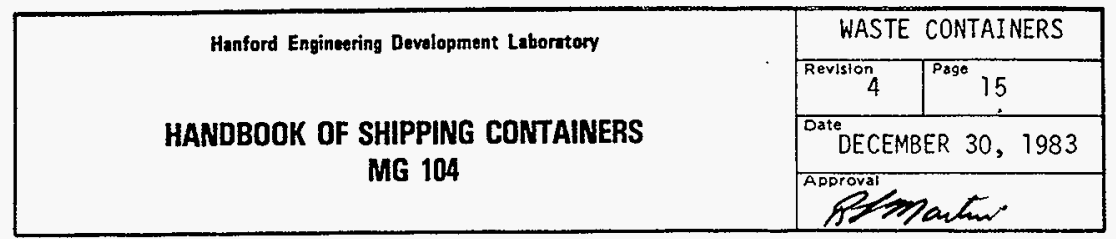

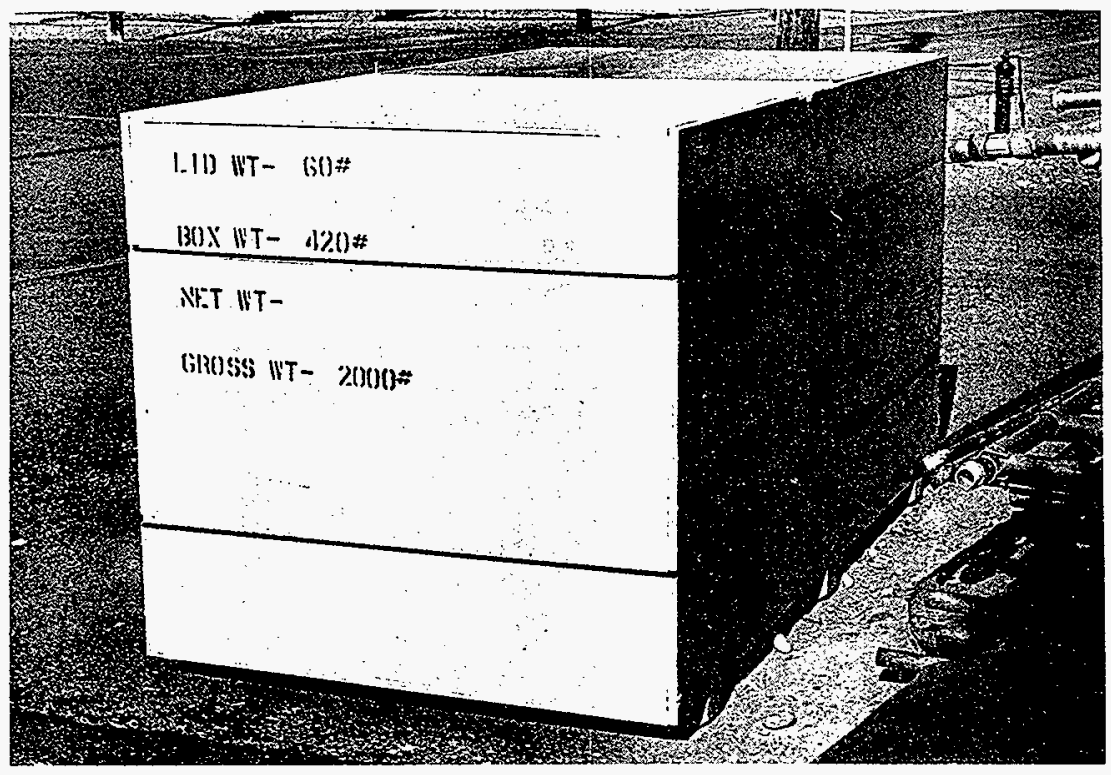

1. COMMON NAME: Plywood Burial Box

2. OFFICIAL NAME: Plywood Burial Container $4 \times 4 \times 8$

3. CONTAINER EXTERIOR DIMENSIONS: Various, between $24^{\prime \prime} \times 24^{\prime \prime} \times 36^{\prime \prime}$ and $48^{\prime \prime} \times 60^{\prime \prime} \times 96^{\prime \prime}$ INTERIOR DIMENSIONS: Various, between $23^{\prime \prime} \times 23^{\prime \prime} \times 35^{\prime \prime}$ and $47^{\prime \prime} \times 59^{\prime \prime} \times 95^{\prime \prime}$ EMPTY WEIGHT: $300-420$ pounds MAXIMUM GROSS WEIGHT: depends on size: 2000 1bs max SHIELDING MATERIAL: Wood THICKNESS: $3 / 4^{\prime \prime}$ DESCRIPTION DRAWING NO. N/A A family of single trip, wooden burial boxes constructed of $3 / 4$ " plywood. A

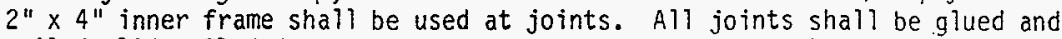
nailed; lid nailed down. A minimum of 2 steel bands shall be used. FOR INFORMATION CONTACT: WSO, 6-3012

No. OF AVAILABLE CONTAINERS: To be bujlt as specified 


\begin{tabular}{|c|c|}
\hline \multirow{4}{*}{$\begin{array}{l}\text { HANDBOOK OF SHIPPING CONTAINERS } \\
\text { MG } 104\end{array}$} & WASTE CONTAINERS \\
\hline & ${ }^{\text {Page }} 23$ \\
\hline & $\begin{array}{l}\text { Date } \\
\text { DECEMBER } 30,1983\end{array}$ \\
\hline & Plentant. \\
\hline
\end{tabular}
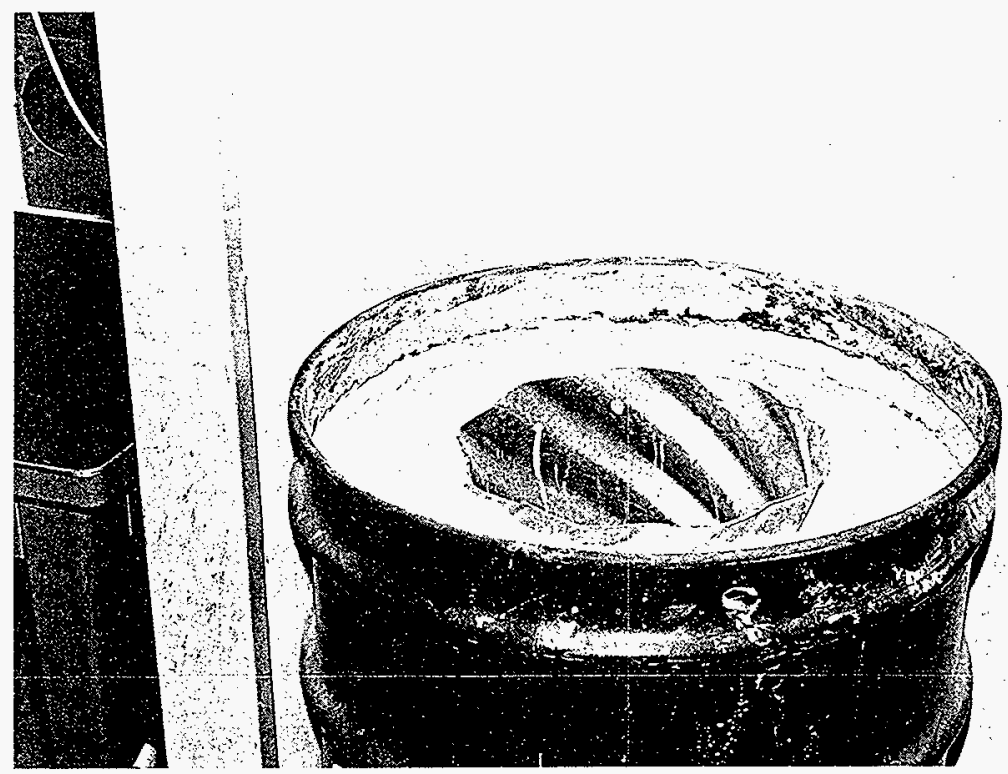

1. COMMON NAME: Concrete Drum Non TRU

2. OFFICIAL NAME: Concrete Shielding Drum

3. CONTAINER EXTERIOR DIMENSIONS: $24^{\prime \prime} 00 \times 33-1 / 4^{\prime \prime} \mathrm{H}$

$$
\text { INTERIOR DIMENSIONS: }
$$

EMPTY WEIGHT: $\simeq 700$ pounds

SHIELDING MATERIAL: concrete

DESCRIPTION

$\frac{12 " \mathrm{OD} \times 26^{\prime \prime} \mathrm{H}}{\text { MAXIMUM GROSS WEIGHT: } 860 \text { pounds }}$

THICKNESS: 6 "

DRAWING No. Shop built

Built by Waste Systems Operations per requirements.

FOR INFORMATION CONTACT: Waste System Operations, 6-3012

No. OF AVAILABLE CONTAINERS: as ordered 


\begin{tabular}{|c|c|c|}
\hline \multirow{4}{*}{$\begin{array}{l}\text { HANDBOOK OF SHIPPING CONTAINERS } \\
\text { MG } 104\end{array}$} & \multicolumn{2}{|c|}{ WASTE CONTAINERS } \\
\hline & $\begin{array}{c}\text { Rovision } \\
6\end{array}$ & ${ }_{27}^{\text {Pag॰ }}$ \\
\hline & \multicolumn{2}{|c|}{ Dato DEC. 1,1984} \\
\hline & \multicolumn{2}{|c|}{ Approyng patm. } \\
\hline
\end{tabular}

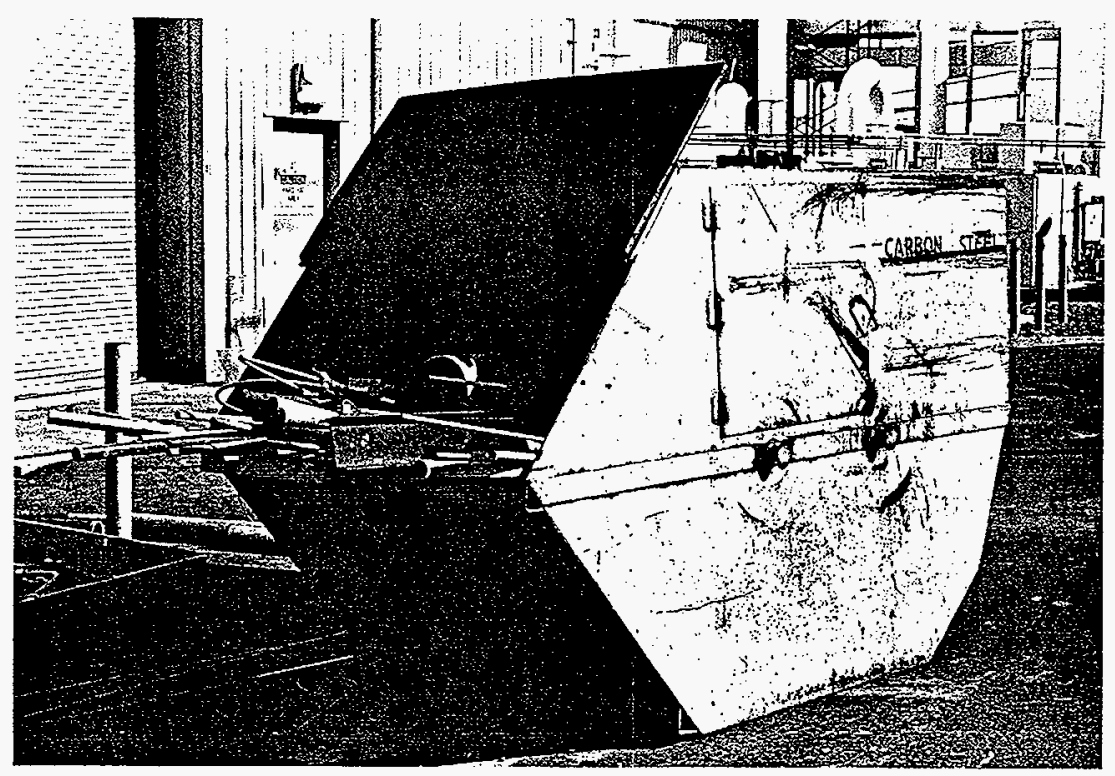

1. COMMON NAME: SCrap Lugger

2. OFFICIAL NAME: Load Lugger

3. CONTAINER EXTERIOR DIMENSIONS: $8^{\prime} \mathrm{L} \times 6^{\prime} \mathrm{W} ; 3$ depths: $3^{\prime}$ or $4-1 / 2^{\prime}$ or $7^{\prime}$ INTERIOR DIMENSIONS:

EMPTY WEIGHT: 2000 IDS

SHIELDING MATERIAL: NONE THICKNESS:

DESCRIPTION DRAWING No.

Available with open tops or lids that can be locked for control of material. FOR INFORMATION CONTACT: RHO Transportation

No. OF AVAILABLE CONTAINERS: from RHO 


\section{HANDBOOK OF SHIPPING CONTAINERS MG 104}

\begin{tabular}{|c|c|}
\hline $\begin{array}{r}\text { Rovision } \\
4\end{array}$ & 9 \\
\hline \multicolumn{2}{|c|}{ DECEMBER 30,1983} \\
\hline
\end{tabular}

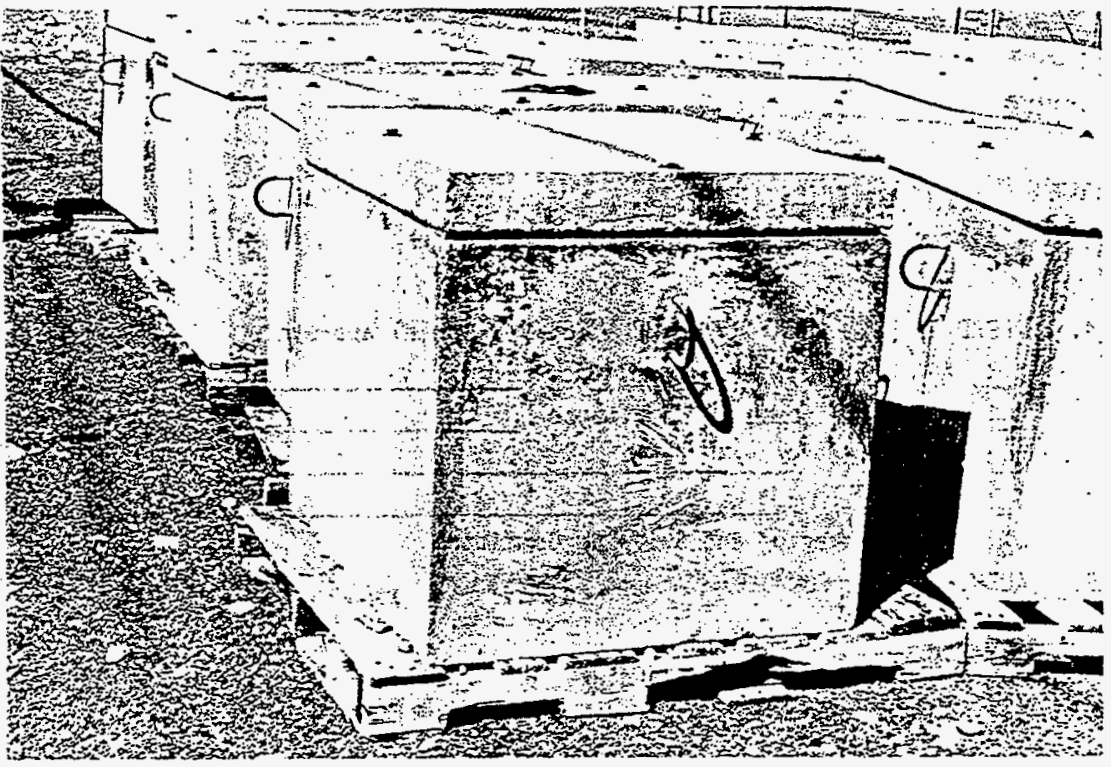

1. COMMON NAME: Non-TRU Concrete Filter Burial BOX

2. OFFICIAL NAME: Non-TRU Concrete Filter Burial Box

3. CONTAINER EXTERIOR DIMENSIONS: $34^{*} \times 34^{\prime \prime} \times 34^{\prime \prime}$

INTERIOR OIMENSIONS: $30^{\prime \prime} \times 30^{\prime \prime} \times 26^{\prime \prime}$

EMPTY WEIGHT: 2400 pounds MAXIMUM GROSS WEIGHT: 2420 pounds

SHIELDING MATERIAL: Concrete THICKNESS: $4^{\text {" }}$

DESCRIPTION DRAWING NO. H-3-35290

Constructed of $3000 \mathrm{ibs} / \mathrm{sq}$ in. concrete. Lid is sealed with neoprene gasket; bonded with Silicon rubber (Dow Corning RTV-732).

FOR INFORMATION CONTACT: Waste Systems Operations, 6-3012

No. OF AVAILABLE CONTAINERS: 20 


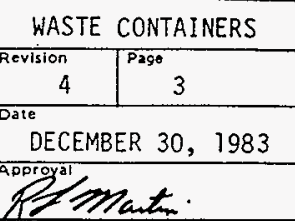

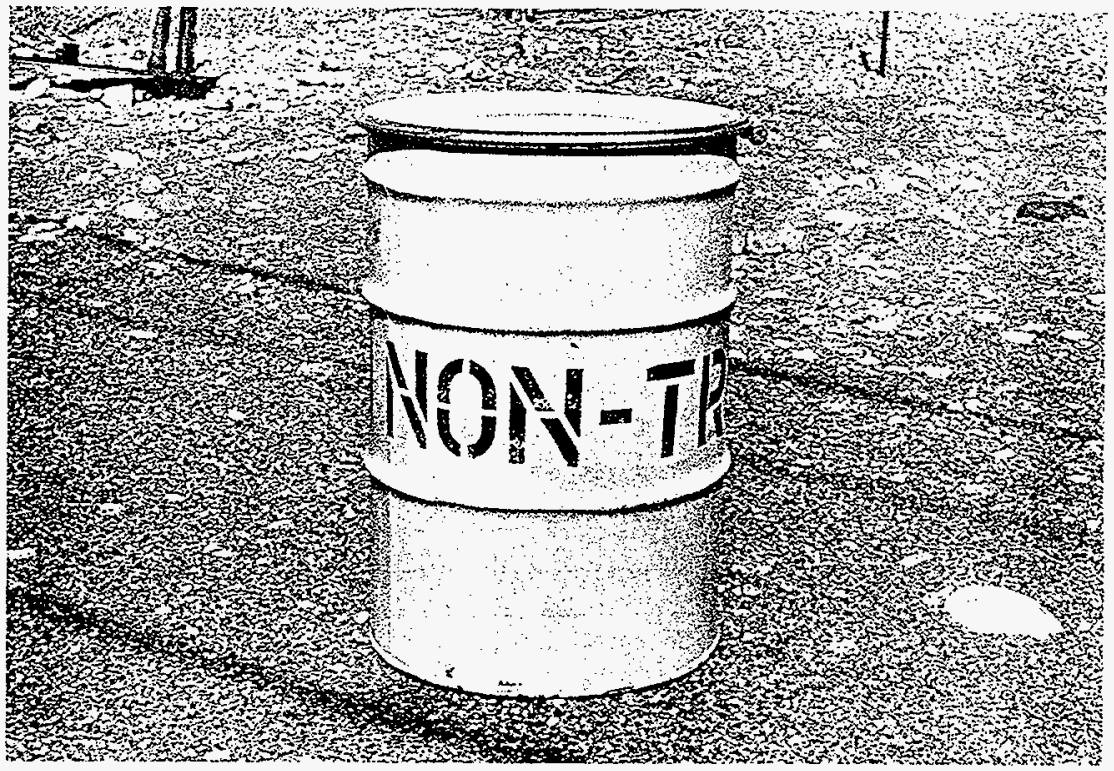

1. COMMON NAME: 55 gallon steel drum/30 gallon steel orum

2. OFFICIAL NAME: DOT SPEC $17 \mathrm{H}$ drums

3. CONTAINER EXTERIOR DIMENSIONS: $24^{\prime \prime} 00 \times 35^{\prime \prime} \mathrm{H} / 20^{\prime \prime} 00 \times 29-1 / 2^{\prime \prime} \mathrm{H}$

INTERIOR DIMENSIONS: $22-1 / 2^{\prime \prime}$ Diam $\times 33-1 / 4^{*} \mathrm{H} / 18^{\prime \prime}$ Diam $\times 28^{\prime \prime} \mathrm{H}$

EMPTY WEIGHT: 50 lbs/ 35 lbs MAXIMUM GROSS WEIGHT: 840 pounds/400 pounds

SHIELDING MATERIAL: Stee 1 THICKNESS: 18 gauge minimum thickness

DESCRIPTION DRAWING No. 49 CFR 178.118

Single trip steel 18 gauge waste containers. Lids shall be bolted and torqued to $40-\mathrm{ft}$ lbs.

FOR INFORMATION CONTACT: Waste Systems Operations, RHO Stores

No. OF AVAILABLE CONTAINERS: Call WSO, 6-3012 to order 55 gallon drums, 30 gallon size available from $\mathrm{RHO}$ stores, Caption 42, Item No. 42-2230-200. 


\begin{tabular}{|c|c|}
\hline $\begin{array}{c}\text { Revision } \\
5\end{array}$ & Page \\
\hline Datio JUNE & 5 \\
\hline ADoroval & 1984 \\
\hline
\end{tabular}

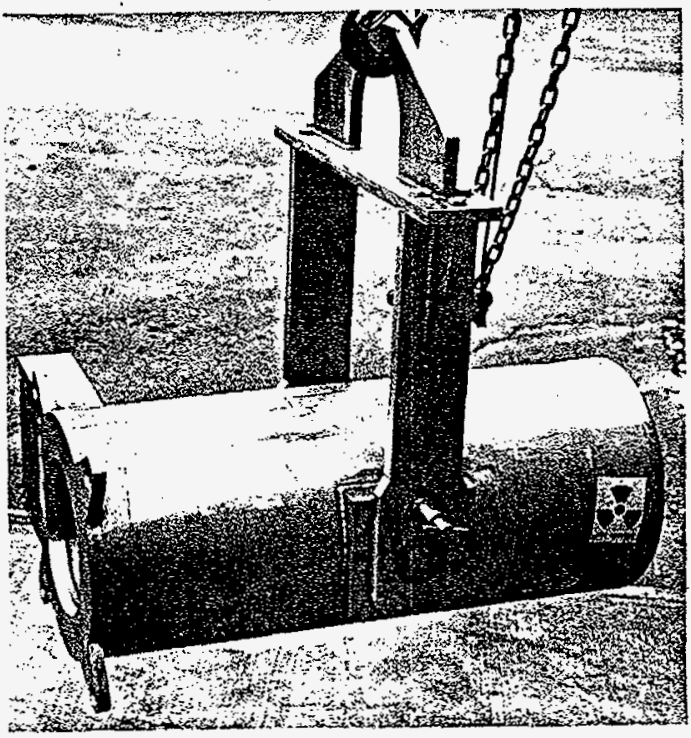

1. COMMON NAME: Tin Can Waste Cask

2. OFFICIAL NAME: $325-8$ Waste Disposal Cask

3. CONTAINER EXTERIOR DIMENSIONS: $14 " 00 \times 29 " \mathrm{~L} ; 14^{\prime \prime} 00 \times 33^{\prime \prime} \mathrm{L}$

INTERIOR DIMENSIONS: $81 / 4^{\prime \prime}$ diam. $\times 22^{\prime \prime} \mathrm{H} ; 81 / 4^{\prime \prime}$ diam $\times 26^{\prime \prime} \mathrm{H}$

EMPTY WEIGHT: 1300 ibs/1400 IbS MAXIMUM GROSS WEIGHT: 1360 lbs/115 pounds SHIELOING MATERIAL: Lead THICKNESS: 2"

DESCRIPTION

DRAWING No. $\mathrm{H}-3-19558\left(29^{\prime \prime}\right) / \mathrm{H}-3-28968\left(33^{\prime \prime}\right)$

Two similar casks except for length and weight. Each is equipped with yoke for loading. They are normally horizontally loaded - but may be palletmounted vertically after loading. Each accomnodates $m .5 \mathrm{cu}$. feet of waste. See special conditions.

FOR INFORMATION CONTACT: Analytical Chemistry Dept., 6-3089

NO. OF AVAILABLE CONTAINERS: 2 


\begin{tabular}{|c|c|c|}
\hline \multirow{4}{*}{$\begin{array}{l}\text { HANDBOOK OF SHIPPING CONTAINERS } \\
\text { MG } 104\end{array}$} & \multicolumn{2}{|c|}{ WASTTE CONTAINERS } \\
\hline & $\begin{array}{c}\text { Rovislon } \\
5\end{array}$ & ${ }^{\text {Page }} 7$ \\
\hline & \multicolumn{2}{|c|}{ JUNE 1, 1984} \\
\hline & \multicolumn{2}{|c|}{ ADrovab foy $x=$} \\
\hline
\end{tabular}

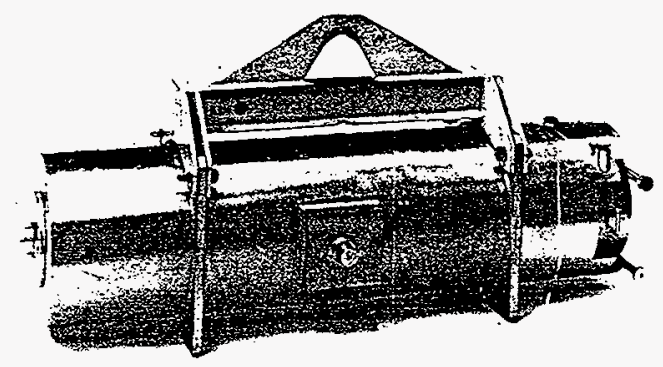

1. COMMON NAME: 327 Waste Cask

2. OFFICIAL NAME: Radioactive Waste Disposal Cask

3. CONTAINER EXTERIOR DIMENSIONS: $22^{\prime \prime}$ Diam. $\times 80^{\prime \prime} \mathrm{L}$

INTERIOR DIMENSIONS: $8.715^{\prime \prime}\left(7.685^{\prime \prime}\right.$ w/Liner $) \times 64-1 / 4^{\prime \prime} \mathrm{L}$

EMPTY WEIGHT: 9500 pounds MAXIMUM GROSS WEIGHT: 9560

SHIELDING MATERIAL: Lead _ THICKNESS: 5-5/8"

DESCRIPTION

ORAWING NO. H-3-19831

A cylindrical, horizontally-oriented cask. It accommodates 8,1 gal cans, or approximately 1.24 cubic feet of waste.

FOR INFORMATION CONTACT: Post Irradiation Testina, 6-5431

NO. OF AVAILABLE CONTAINERS: 1 
HNF-EP-0649, Rev. 0

ENCLOSURE

\section{APPENDIX D}

327 BUILDING MILK PALL CASK OPERATING PROCEDURE 


\section{MIIK PAIL CASK OPERATIKG FROCEDURES}

\section{DISCUSSION}

\section{Purpose:}

The purpose of the milk pail cask is the removal of large volumes of intermediate level radicactive wastes from any standard cell in the 327 building. The cask is intended to eliminate the use of cardboard cartons for the removal of celi wastes except in the case of very large volumes of very low level material. The milk pail cask will also largely supplant the waste cask previously used for the removal of small volumes of higher level wastes.

\section{Advantages:}

The primary advantages of the milk pail cask are that it reduces contamination outside the cell and greatly reduces radiation exposure to Radiometaliurgy ptersonnel during waste removal and to personnel handiling the waste at the burial grounds. Another advantage is that large, odd shaped objects may be removed in it. The cask vill hold 8 "rilk peil" 7 inches in diameter and 10 inches high, or any other object of that approximate size and shape. It provides a shield of 4 inches of lead on the sides, and 2 inches of jead on the bottom. In addition, the milk pails will normally contain gelatin during renoval which will provide shielding slightly greater than an tauivalent volume of water.

\section{Iimitations and Precautions:}

Milk pails must be handled with care so that they maintain their shape for removal from the cell. No more than 30 lbs. of waste, including gelatin, should be loaded into a pail. (A full pail of gelatin welghs about 13 lbs.) The pail must be lifted carefully to prevent jambing it against the cell roof or in the port.

Milk pails, being made of aluminum, are soluble in any caustic, particularly sodium hydroxide, NaOH. Any such contact should be avolded, elther liquid or dry. 
Gelatin must be prepared properly and allowed to set at least 16 hours, before removal from a cel1. (A procedure for gelatin preparation is presented in a separate section of this operating procedure.) No signiffcant amount of any free liquid should ever be put into a milk pail in a cell. To do so might dilute the gelatin or modify its structure, reducing its strength. For the same reason, no chemical of any sort (including NaK) should be put into a pall unless it is in a sealed container.

objects which flost in gelatin should be punctured or weighted down before the gelatin is added. Any object that is not completely submerged in gelatin, should be "squirted" during pouring so that all surfaces are coated, and all particulate contamination trapped.

The slide should always be locked as soon as the cask is loaded. The exterlor of the pall and the ball should be kept as clean as possible at all times to minimize contamination of the cask (and in turn, contaminating the trailer, truck and highway.) OPERATING PROCEDURES

I. Pail Freparation:

In preparing a pail for use, these steps are to be followed:

1. Check the bail for strength and the pail for shape.

2. Dry the outside of the pail.

3. Obtain a dry polyethylene bag $12^{\prime \prime} \times 15^{\prime \prime}$ from the chemical prep. room.

4. Dust the interior of the bag with talc, and insert the pail into 1 .

5. Fold the excess plastic into a neat fold and fasten with two rubber bands about 1/4" from the top lip of the pail.

6. Fix a paper clip around the rubber bands so they can be removed by pulling the clip off the top of the pail.

The pail is then ready to place in the cell. CAUTION: The rubber bands mast be placed near the top, above the rivets and must be tight enough to hold the plastic bag on the pall when loading into the cell in a strong draft. (Otherwise the bag may be sucked off the pail.) Do not drop the pail into the cell. This may camage the pail so that removal i-s difficult. 


\section{Gelatin Preparation:}

Estimate the volume of gelatin solution required. The volume of the pail is six liters. There is no harm in ming a slight miscalculation in the amount of solution prepared but the concentration must be correct. To prepare the gelatin solution, divide the estimated volume required in milliliters by 4 and weigh out that many grams of dry gelatin. For instance, to prepare 4 liters of gelatin solution, use 4 thousand grams of water (4 ifters) and 1 thousand grams of dry gelatin. The concentration of the gelatin solution will then be $20 \%$. Ordinarily, bot water from the tap is sufficient to dissolve the gelatin. However there is no harm in warming it slightly on the hot plate. It is not necessary to heat the rater or the solution above $80^{\circ} \mathrm{C}$. Add the gelatin to the water while stirring vigorously With the electric stirrer. The gelatin mave a tendency to form lumps or to flost on top, but it will all dissolve within 3 to 5 minutes if thoroughly mixed. The gelatin solution should be poured into the pail soon after mixing, as it will start to set if allowed to cool or stand for more than 30 minutes. A portable funnel with a male taper jo:nt and stand are provided for adding the gelatin through eash cell top. Each cell has the female portion of a taper joint attached to a tygon tube running through the cell top. Where cells are equipped with a drain, this tubing mast be rinsed with hot water both before and after adding the gelatin to the pail in the cell. Be certain, however, that the hot water does not go into the pail to be filled with gelatin. Also, all gelatin spilled on the tray mast be flushed into the "hot" crib line with hot water as soon as possible.

\section{Cask Eanding:}

Generaliy, the operation will start with the removel of the cask from the trailer or truck after it is backed into the canyon.

1. Remove the retaining studs employed to hold down the cask.

2. As soon es the cask is removed, request RMO to check the truck or trailer. 
Then decontaminate as necessary, especially the inside of the chute. If there is a plastic bag covering the chute bottom, remove it at this time.

3. Remove the appropriate cell plug and insert the aligning plate. Avoid any direct exposure from the cell during these operations.

4. With the cask near the hole, unlock and open the slide.

5. Iower the cask into position over the hole.

6. Remove the top plug from the cask, and insert the hook and cable tbrough the top and into the celi.

7. An operator with a manipulator should remove the rubber bands and paper clip from the can and discard it in the cell (not in the can) and then attach the hook to the bail. During this operation every effort should be made to avoid contamination of the hook and pail.

8. As the pail is raised, the manipulator operator should remove the plasilic bag by pulling it from the bottom, again being cautious to avoid contamination of the pail.

9. Raise the peil carefulizy into the cask and close and lock the slide. Check the lock to be certain it is properly locked.

10. Withoraw the cable and insert the top plug.

11. Immediately swab the cable and hook to remove possible contamination.

12. Remove the cask with the crane, withdraw the aligning plate, and reinsert the cell plug.

13. Swab the aligning plate.

14. Avoid direct exposure of any personnel to the bottom face of the cask (which has only 2 inches of lead shielding.)

15. Check the cask bottom for contamination and clean if necessary.

16. Return the cask to the trailer facing the slide to the front of the trailer.

17. Bolt the cask down.

18. Recheck to be certain the slide is locked closed. 
18. Obtain RMO clearance for truck or trailer removal.

IV. Cask Decontamination:

The cask should be decontaminated as necessary, or routinely after about six runs. Reinove and discard the plastic boot covering the slide. Remove the slide stops and slide. Suspend the cask in a horizontal position (Using both crane hooks) and swab. Nitric acid may be used except on the brass knob and plug. Always follow ac1d wash with clean water. Then acetone may be used.
I. Thurner
CL Boyd
OC MCCormack
RL Brandt
IJ Defferding
WJ Gruber
ME Mexahan
$R$ Teats 
HNF-EP-0649, Rev, 0

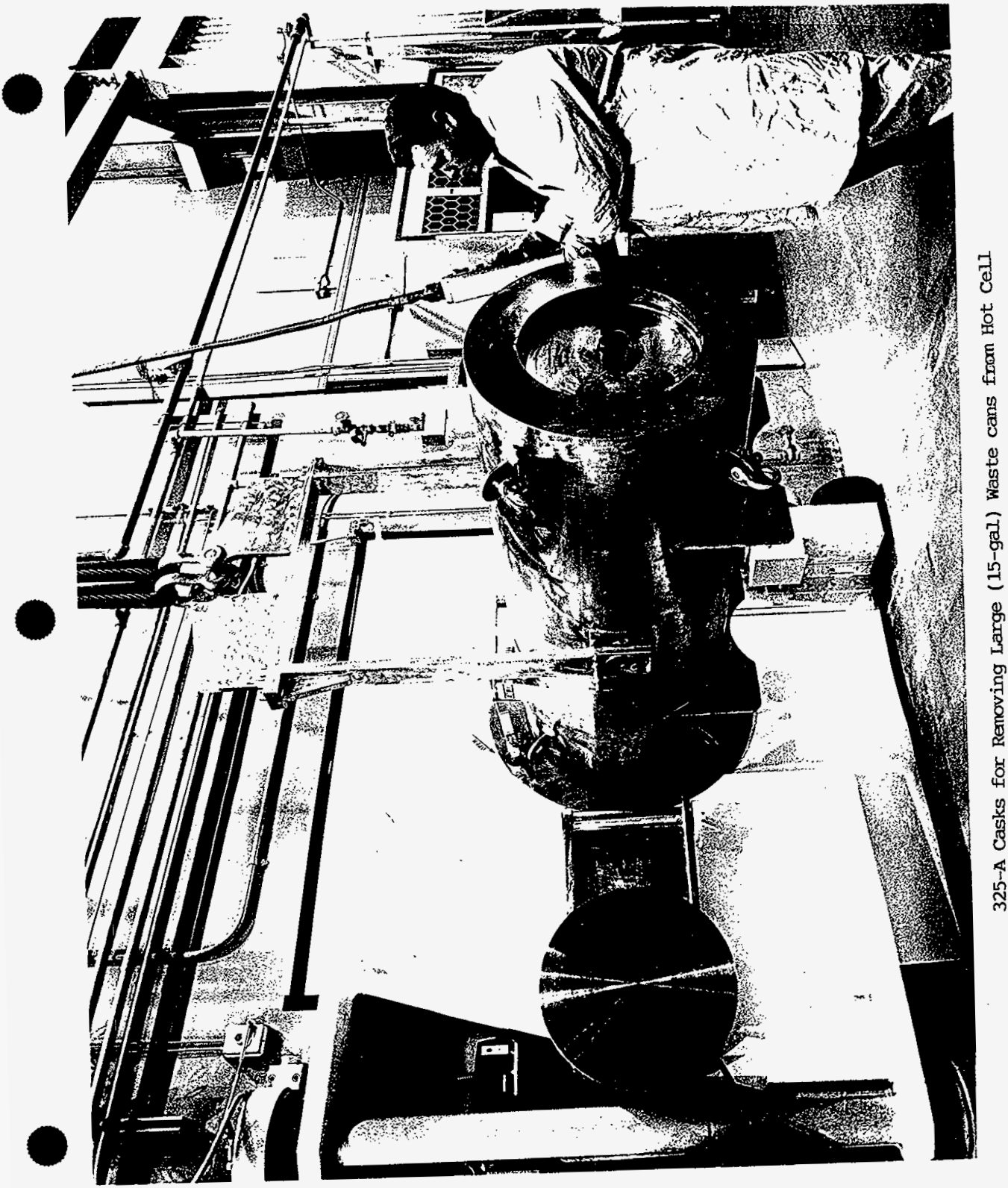


HNF-EP-0649, Rev. 0

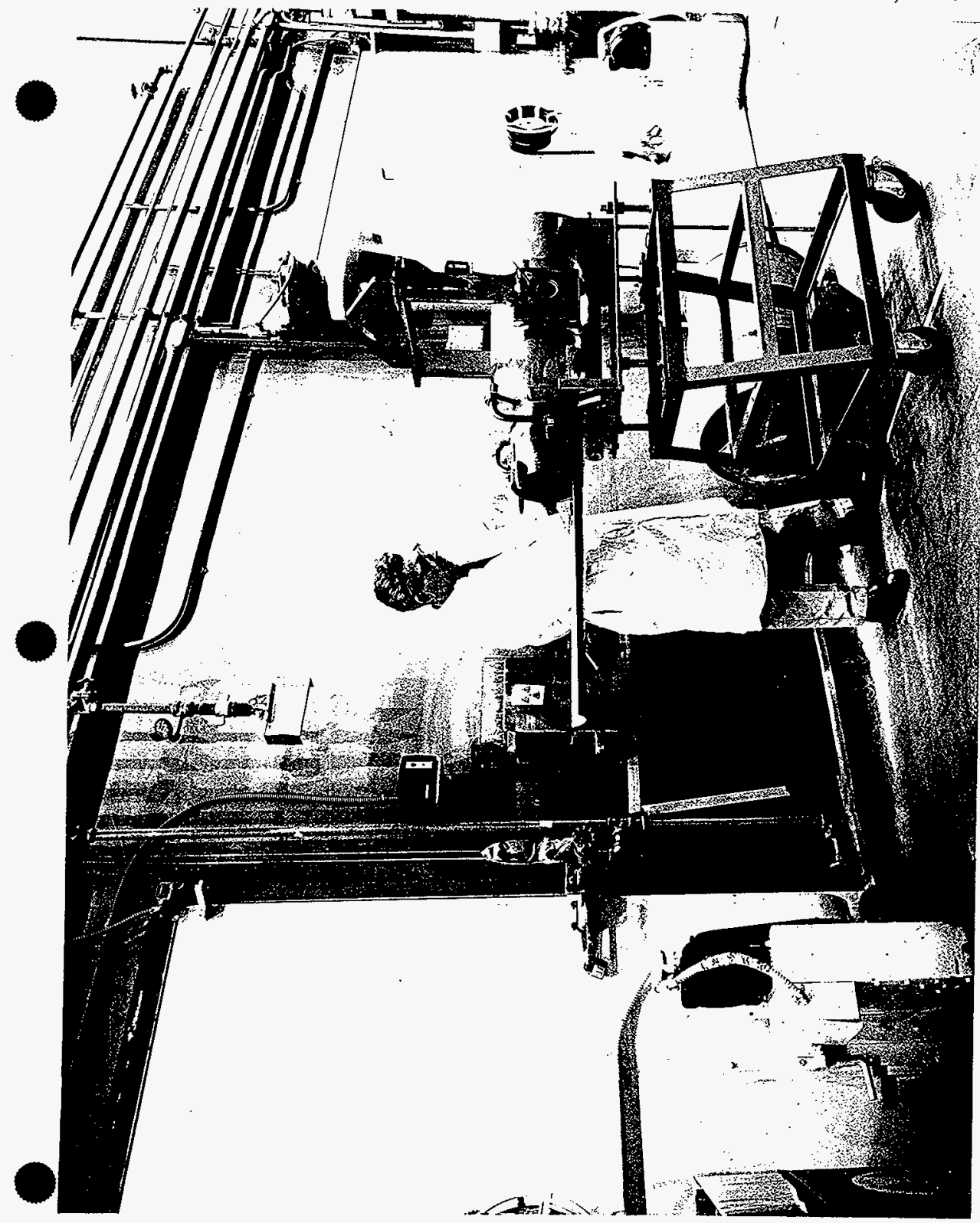

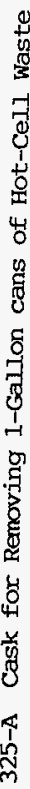


HNF-EP-0649, Rev. 0

ENCLOSURE

\section{APPENDIX E}

BURIAL SITE SHIPPING RECORDS (300-N \& WYE)

REPORTING PERIOD - JAN. 1, 1962 - Dec. 31, 1967 
HNF-EP-0649, Rev. 0

APPENDIX E

BURIAL SITE SHIPPING RECORDS - JAN. 1, TO JUNE 30, 1962

Radioactivity

Level

Waste Description

Quantity $\frac{\text { Volume }}{\text { (cu.m.) }}$

$10-1000 \mathrm{Ci} / \mathrm{ft} 3$

50 Gallon Drums filled

89

18.7

Under $10 \mathrm{Ci} / \mathrm{ft} 3$

with concrete

10-1000 Ci/ft3 Milk Pail Cans

2,448

311.8

$10-1000 \mathrm{Ci} / \mathrm{As}$

Over $1000 \mathrm{Ci} / \mathrm{ft} 3 \quad$ Stainless Steel Cans

198

1.42

Over $1000 \mathrm{Ci} / \mathrm{A3}$

Stainless Steel Cans

Under $10 \mathrm{Ci} / \mathrm{ft} 3$ Lead in Wooden Crate

75

0.14

Under $10 \mathrm{Ci} / \mathrm{ft3} \quad$ Steel Cave Liner (plastic)

1

0.34

1

2.04

Burial Ground Assignment: $249.9 \mathrm{~m} 3$ cartons went to the Wye facility and $61.9 \mathrm{~m} 3$ went to the $300-\mathrm{N}$ burial ground. $14.4 \mathrm{~m} 3$ drums of concrete went to the Wye and $4.3 \mathrm{~m} 3$ went to the $300-\mathrm{N}$ facility.

BURIAL SITE SHIPPING RECORDS - JULY 1 TO DEC. 31,1962

(Wye only, facility closed on Oct.2, 1962)

Radioactivity

Level

Waste Description

Quantity Volume

(m3)

$10-1000 \mathrm{Ci} / \mathrm{ft} 3$

50 Gallon Drums Filled

40

8.49

Under $10 \mathrm{Ci} / \mathrm{ft} 3$ with concrete

Cardboard Cartons

1642

209.1

Estimated Acreage used during the reporting period 15,000 sq. $\mathrm{ft}$. 
HNF-EP-0649, Rev. 0

BURIAL SITE SHIPPING RECORDS - JUY 1 TO DEC. 31, 1963

(Wye only, facility re-opened Sept. 1963)

Radioactivity

$\underline{\text { level }}$

Waste Description

Quantity Volume

(m3)

Under $10 \mathrm{Ci} / \mathrm{ft} 3$

Cardboard Cartons

1,660

211.4

$10-1000 \mathrm{Ci} / \mathrm{ft} 3$

50 Gallon Drums

20

4.25

$10-1000 \mathrm{Ci} / \mathrm{ft} 3$

Milk Pail Cans

151

1.08

Over $1000 \mathrm{Ci} / \mathrm{ft} 3 \quad$ Stainless Steel Cans

(Gatling Gun cans)

Estimated Acreage used During the Reporting Period: 4500 sq.ft.

BURIAL SITE SHIPPING RECORDS - JAN. 1 TO JUNE 30, 1964

(300-Wye)

Radioactivity

Level

Waste Description

Quantity Volume

Under $10 \mathrm{Ci} / \mathrm{ft} 3 \quad$ Cardboard Cartons

$3,750 \quad 477.6$

Under $10 \mathrm{Ci} / \mathrm{ft} 3 \quad 50$ Gallon Drums

25

5.31

10-1000 Ci/ft3 Milk Pail Cans

425

2.21

Over $1000 \mathrm{Ci} / \mathrm{ft} 3$

Gatling Gun Cans

150

0.14

Estimated Area used during the Reporting Period: 16,000 sq.ft. 
HNF-EP-0649, Rev. 0

BURIAL SITE SHIPPING RECORDS - JULY 1 TO DEC. 31, 1964 (300-Wye)

Radioactivity

Level

Waste Description

Quantity Volume

Under $10 \mathrm{Ci} / \mathrm{ft} 3 \quad$ Cardboard Cartons

$4,875 \quad 620.8$

Under $10 \mathrm{Ci} / \mathrm{ft} 3 \quad 50$ Gallon Drums

16

3.40

$10-1000 \mathrm{Ci} / \mathrm{f} 3 \quad$ Milk Pail Cans

384

1.73

$10-1000 \mathrm{Ci} / \mathrm{ft} 3 \quad$ Hot Cell Pails $(5$ gal.)

23

0.65

Over $1000 \mathrm{Ci} / \mathrm{f} 3$ Gatling Gun Cans

56

0.06

Estimated Area Used During the Reporting Period: 22,000 sq. ft.

BURIAL SITE SHIPPING RECORDS - JAN 1 TO JUNE 30, 1965 (300-Wye)

Radioactivity

Level

Waste Description

Quantity $\frac{\text { Volume }}{(\mathrm{m} 3)}$

Under $10 \mathrm{Ci} / \mathrm{ft} 3 \quad$ Cardboard Cartons

4,225

538.1

" " " 55 Gallon Drums

400

84.9

" " " Wooden Crates

10

13.58

$10-1000 \mathrm{Ci} / \mathrm{ft3}$

Milk Pail Cans

420

1.58

" " " Waste Pails (5 gal hot-cell)

6

0.11

" " " Waste Cans (3 ft3)

48

3.25

Over $1000 \mathrm{Ci} / \mathrm{ft} 3$ Gatling Gun Cans

135

0.16

Estimated Area Used During the Reporting Period: 20,000 sq. ft. 
BURIAL SITE SHIPPING RECORDS - JULY 1 TO DEC. 31, 1965 (300 Wye)

Radioactivity

\begin{tabular}{|c|c|c|c|}
\hline Level & Waste Description & Quantity & $\frac{\text { Volume }}{(\mathrm{m} 3)}$ \\
\hline Under $10 \mathrm{Ci} / \mathrm{ft} 3$ & Cardboard Cartons & 3,953 & 503.4 \\
\hline " " "Woo & Crates & 8 & 10.87 \\
\hline $10-1000 \mathrm{Ci} / \mathrm{ft} 3$ & Milk Pail Cans & 369 & 1.42 \\
\hline " " " " & ans $(2 \mathrm{ft} 3)$ & 47 & 2.66 \\
\hline 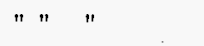 & CWS Filters & 6 & 1.36 \\
\hline Over $1000 \mathrm{Ci} / \mathrm{ft} 3$ & Gatling Gun Cans & 146 & 0.17 \\
\hline
\end{tabular}

Estimated Area Used During Reporting Period: 15,000 sq. ft.

BURIAL GROUND SHIPPING RECORDS - JAN 1 TO JUNE 30, 1966 (300-Wye)

Radioactivity

Level

Waste Description

Quantity Volume

(m3)

Under $10 \mathrm{Ci} / \mathrm{ft} 3$

Cardboard Cartons

3,132

398.9

$10-1000 \mathrm{Ci} / \mathrm{ft} 3$

Milk Pail Cans

313

1.19

" " $\quad$ " Waste Cans (5 Gal.)
" " " $\quad$ Waste Cans (1 ft3)

4

0.08

19

0.54

Over $1000 \mathrm{Ci} / \mathrm{ft} 3 \quad$ Gatling Gun Cans

123

0.14

Estimated Area Used During Reporting Period: 15,000 sq. ft. 
HNF-EP-0649, Rev. 0

APPENDIX E

BURIAL GROUND SHIPPING RECORDS - JULY 1 TO DEC. 31, 1966 (300 Wye)

Radioactivity

Level

Waste Description

Quantity Volume

(m3)

Under $10 \mathrm{Ci} / \mathrm{ft} 3 \quad$ Cardboard Cartons

2,113

269.1

$10-1000 \mathrm{Ci} / \mathrm{ft} 3$

Milk Pail Cans

230

0.88

$n n$

Waste Cans (5 gal.)

8

0.14

" " " Waste Cans (1 ft3)

27

0.48

Estimated Area Used During Reporting Period: 10,000 sq. ft.

\section{BURIAL GROUND SHIPPING RECORDS - JAN. 1 TO JUNE 30, 1967} (300 Wye)

Radioactivity

Level

Waste Description

Quantity Volume

(m3)

Under $10 \mathrm{Ci} / \mathrm{ft} 3$

Cardboard Cartons

2,800

356.6

$10-1000 \mathrm{Ci} / \mathrm{ft} 3$

Milk Pail Cans

438

1.70

" " " Waste Cans (5-Gal.)

6

0.11

" " " Waste Cans (1 ft3)

5

0.14

Estimated Area Used During Reporting Period: 12,000 sq. ft. 


\section{BURIAL GROUND SHIPPING RECORDS - JULY 1 TO DEC. 31, 1967} (300 Wye)

Radioactivity

Level

Under $10 \mathrm{Ci} / \mathrm{ft} 3 \quad$ Cardboard Cartons

10-1000 Ci/ft3 Milk Pail Cans

" " " Waste Cans (5-Gal.)

" 11

Waste Cans (1 $\mathrm{ft} 3)$

Quantity $\frac{\text { Volume }}{(\mathrm{m} 3)}$

3,311

421.7

370

1.39

40

0.76

38

1.08

Estimated Area Used During Reporting Period: 15,000 sq. ft. Wye Burial Ground Closed on 12/31/67 permanently! 


\section{HNF-EP-0649, Rev. 0}

ENCLOSURE

\section{APPENDIX F}

DATA FROM MONTHLY ACTIVITY REPORTS 
"Hanford Laboratories Monthly Activities Report"

Hanford Atomic Products Operation, Richland, WA, 1962-1964

\begin{tabular}{|c|c|c|c|c|c|c|c|}
\hline Date & Doc. No. & \multicolumn{2}{|c|}{ 325 Luggers } & \multicolumn{2}{|c|}{ Concrete Barrels } & Milk Pails & Gatling Guns \\
\hline $1 / 62$ & HW-73202 & 3 & $(300-N)$ & 12 shipments & 23 & 1 & \\
\hline $2 / 62$ & HW-73202 & 3 & " & 4 shipments & -. & -- & \\
\hline $3 / 62$ & HW-73514 & 5 & (Wye) & 21 shipments & --- & - & \\
\hline $4 / 62$ & HW-73905 & 4 & $"$ & 3 shipments & --- & -- & \\
\hline $5 / 62$ & HW-74153 & 4 & $"$ & 3 shipments & --- & --- & \\
\hline $6 / 62$ & HW-74522 & 1 & $"$ & 4 shipments & $-\ldots$ & -.- & \\
\hline $7 / 62$ & HW-74813 & 2 & $"$ & 2 shipments & ..- & $\ldots$ & \\
\hline
\end{tabular}

\begin{tabular}{|c|c|c|c|c|c|}
\hline Date & Doc. No. & 300 Luggers & 325 Luggers & Concrete Barrels & Ground \\
\hline \multirow[t]{2}{*}{$8 / 62$} & HW-75127 & 37 & 2 & 8 barrels ( 2 shipments) Wye & \multirow[t]{2}{*}{$9 / 62$} \\
\hline & HW-75376 & 49 & --- & 8 batrels & \\
\hline $10 / 62$ & HW-75625 & 48 & -.- & $300-\mathrm{N}$ & \\
\hline $11 / 62$ & HW-75925 & 40 & --- & $16 "$ & $"$ \\
\hline $12 / 62$ & HW-76315 & 27 & --- & $12 "$ & $"$ \\
\hline $1 / 63$ & HW-76596 & 29 & --- & $8 "$ & $300-\mathrm{N}$ \\
\hline \multirow{2}{*}{$2 / 63$} & $\mathrm{HW}-77046$ & 29 & --- & $26 "$ & \\
\hline & HW-77397 & 28 & $\ldots$ & $12 "$ & $"$ \\
\hline $4 / 63$ & HW-77709 & 25 & 4 & $4 "$ & $300-\mathrm{N}$ \\
\hline $5 / 63$ & HW-78052 & 25 & 4 & $20 "$ & $"$ \\
\hline $6 / 63$ & HW-78420 & 19 & 3 & $8 "$ & $"$ \\
\hline $7 / 63$ & HW-78758 & 21 & 4 & $12 "$ & $"$ \\
\hline $8 / 63$ & HW-79046 & 22 & 2 & $20 "$ & $"$ \\
\hline $9 / 63$ & HW-79377 & 7 & 1 & $8 "$ & $"$ \\
\hline$"$ & $"$ & 13 & 2 & $10 "$ & 300-Wye \\
\hline$"$ & $"$ & 0 & 1 & $11 "$ & $200-W$ \\
\hline $10 / 63$ & HW-79726 & 25 & 2 & $4 "$ & 300-Wye \\
\hline " & $"$ & 0 & 1 & $0 "$ & $200-W$ \\
\hline $11 / 63$ & HW-79999 & 19 & 3 & $4 "$ & $300-$ Wye \\
\hline$"$ & $"$ & 5 & 0 & $0 "$ & $200-W$ \\
\hline $12 / 63$ & HW-80560 & 16 & 3 & $2 "$ & $300-$ Wye \\
\hline & $"$ & 7 & 0 & $0 "$ & $200-W$ \\
\hline
\end{tabular}




\begin{tabular}{|c|c|c|c|c|c|c|}
\hline Date & Doc. No. & 300 Luggers & 325 Luggers & $\begin{array}{l}\text { Concrete } \\
\text { Barrels }\end{array}$ & $\begin{array}{l}\text { Remote } \\
\text { Containers }\end{array}$ & $\begin{array}{l}\text { Burial } \\
\text { Ground }\end{array}$ \\
\hline $1 / 64$ & HW-81019 & 24 & 4 & $12 "$ & & $300-$ Wye \\
\hline " & $"$ & 10 & 0 & $4 "$ & & $200-W$ \\
\hline $2 / 64$ & HW-81472 & 19 & 2 & $4 "$ & & $300-$ Wye \\
\hline " & " & 7 & 0 & $5 "$ & & $200-W$ \\
\hline & Doc. No. & 300 Luggers & 325 Luggers & $\begin{array}{l}\text { Concrete } \\
\text { Barrels }\end{array}$ & $\begin{array}{l}\text { Remote } \\
\text { Containers }\end{array}$ & $\begin{array}{l}\text { Burial } \\
\text { Ground }\end{array}$ \\
\hline $3 / 64$ & HW-82001 & 26 & 2 & $7 "$ & 115 & $300-$ Wye \\
\hline & $"$ & 7 & 0 & $8 "$ & & $200-\mathrm{W}$ \\
\hline $4 / 64$ & HW- 82428 & 20 & 5 & $2 "$ & 93 & $300-$ Wye \\
\hline & $"$ & 6 & 0 & $5 "$ & & $200-W$ \\
\hline 64 & HW-83000 & 20 & 3 & $3 "$ & 86 & 300 -Wye \\
\hline & $"$ & 5 & 0 & $12 "$ & & $200-W$ \\
\hline
\end{tabular}

\begin{tabular}{|c|c|c|c|c|c|c|}
\hline $\begin{array}{l}\text { Date } \\
\text { - }\end{array}$ & Doc. No. & 300 Luggers & 325 Luggers & $\begin{array}{l}\text { Concrete } \\
\text { Barrels }\end{array}$ & $\begin{array}{l}\text { Remote } \\
\text { Containers }\end{array}$ & $\begin{array}{l}\text { Burial } \\
\text { Ground }\end{array}$ \\
\hline $\begin{array}{l}6 / 64 \\
11\end{array}$ & $\begin{array}{l}\text { HW-83445 } \\
\text { " }\end{array}$ & $\begin{array}{c}21 \\
7\end{array}$ & $\begin{array}{l}4 \\
0\end{array}$ & $\begin{array}{c}10 " \\
9 " .\end{array}$ & 89 & $\begin{array}{l}300-W y e \\
200-W\end{array}$ \\
\hline $\begin{array}{l}7 / 64 \\
" 1\end{array}$ & $\begin{array}{l}H W-83820 \\
"\end{array}$ & $\begin{array}{c}33 \\
7\end{array}$ & $\begin{array}{l}7 \\
0\end{array}$ & $\begin{array}{ll}0 " \\
9 "\end{array}$ & 96 & $\begin{array}{l}300-W y e \\
200-W\end{array}$ \\
\hline $\begin{array}{l}8 / 64 \\
"\end{array}$ & $\begin{array}{l}\text { HW-84291 } \\
\text { " }\end{array}$ & $\begin{array}{c}47 \\
6\end{array}$ & $\begin{array}{l}7 \\
0\end{array}$ & $\begin{array}{c}10 " \\
0 "\end{array}$ & 75 & $\begin{array}{l}300-\text { Wye } \\
200-W\end{array}$ \\
\hline $\begin{array}{l}9 / 64 \\
"\end{array}$ & $\begin{array}{l}\text { HW-84474 } \\
"\end{array}$ & $\begin{array}{c}45 \\
7\end{array}$ & $\begin{array}{l}6 \\
0\end{array}$ & $\begin{array}{c}6 " \prime \\
12 "\end{array}$ & 83 & $\begin{array}{l}300-\text { Wye } \\
200-W\end{array}$ \\
\hline $10 / 64$ & $\begin{array}{l}\text { HW-84529 } \\
\text { " }\end{array}$ & $\begin{array}{c}68 \\
5\end{array}$ & $\begin{array}{c}23 \\
0\end{array}$ & $\begin{array}{l}0 " 1 \\
6 "\end{array}$ & 82 & $\begin{array}{l}300-\text { Wye } \\
200-W\end{array}$ \\
\hline
\end{tabular}


HNF-EP-0649. Rev. 0

ENCLOSURE

\section{APPENDIX G}

DISPOSAL DATA OBTAINED FROM PNL 300 AREA RADIATION

SURVEY RECORDS 


\begin{tabular}{|c|c|c|c|c|c|}
\hline Month \& Year & $\therefore$ & BoX \# & 17950 & .. & \\
\hline खि & $-x^{\prime}$ & ent to the 300 Y Burial $C$ & rounds $\quad \therefore \quad \therefore$ - $\quad \therefore$ & $\cdots \quad \cdots$ & $\therefore$ Volume \\
\hline Date? & Suney Record & No, of Cont & ४ Type of Container $\mathrm{S}^{\mathrm{N}}$ & Generator & $\mathrm{P}_{\text {(cu.m) }}$ \\
\hline 3 & 00820 & & Lugger & 327 & 2.83 \\
\hline 3 & 00816 & & Lugger & 327 & 2.83 \\
\hline 4 & 00817 & 2 ea & Gatling Gun Cask & 327 & 0.0113 \\
\hline 4 & 605489 & & Lugger & 327 & 2.83 \\
\hline 5 & 605498 & & Large Can Cask & $325 \cdot \dot{A}$ & 0.0566 \\
\hline 6 & 605506 & $2 \mathrm{ea}$ & Mot Cell Cask & 325 & 0.019 \\
\hline 6 & 605503 & $3 \mathrm{ea}$ & Milk Pail Cask & 325 & 0.006 \\
\hline 7 & 605510 & & Milk Pail Cask & 327 & 0.006 \\
\hline 11 & 605521 & 1 ea & Hot Cell Cask & $325 \cdot \mathrm{B}$ & 0.0094 \\
\hline 11 & 605521 & & Hot Cell Cask (Paint Can) & $325-8$ & 0.0054 \\
\hline 11 & 605521 & & Lugger & & 2.83 \\
\hline 11 & 605521 & 1 ea & Lugger & $325-B$ & 2.83 \\
\hline 12 & 605525 & 1 ea & Large Can Cask & $325-A$ & 0.0566 \\
\hline 12 & 605525 & 1 ea & Lugger & $325-\mathrm{A}$ & 2.83 \\
\hline 13 & 605528 & & Mifik Pail Cask & 327 & 0.006 \\
\hline 14 & 605521 & & Hot Cell Cask & $325-A \& B$ & 0.019 \\
\hline 14 & 605536 & & Lugger & 327 & 2.83 \\
\hline 14 & 605536 & & Mikk Pail Cask & 327 & 0.005 \\
\hline 18 & 605536 & 2 ea & Hot Cell Cask & $325-\mathrm{A}$ & 0.019 \\
\hline 19 & 605545 & 1 ea & Mik Pail Cask & & 0.005 \\
\hline 20 & 605556 & 1 load & Gatling Gun Cask & 327 & 0.0113 \\
\hline 20 & 605556 & 3 loads & Large Can Cask & & 0.0566 \\
\hline 20 & 605556 & 5 ea & Milk Pail Cask & & 0.006 \\
\hline 21 & 605561 & $8 \mathrm{ea}$ & Mik Pail Cask & 327 & 0.006 \\
\hline 25 & 605568 & $2 \mathrm{ea}$ & Lugget & & 2.83 \\
\hline 25 & 605568 & & Miik Pail Cask & 327 & 0.006 \\
\hline 27 & 605577 & & Hot Cell Cask & $325-A$ & 0.019 \\
\hline 27 & 605577 & $1 \mathrm{ea}$ & Lugger & & 2.83 \\
\hline 27 & 605577 & & Milk Pail Cask & 327 & 0.006 \\
\hline 28 & 505581 & & Hot Cell Cask & 325 & 0.019 \\
\hline 29 & 605585 & $1 \mathrm{ea}$ & Lugger & & 2.83 \\
\hline Mont 8 Yea: & Feb 65 & $14.8 .8 .80 x+\pi$ & 17850 & 4. & $1.4 \%, 4$ \\
\hline & (3). & Hot the sooy Bural 6 & rounds . & & Yolume \\
\hline Date- & Sroverord & No. of conts & W. & \%Generato & $(2 \mathrm{com})$ \\
\hline 1 & 605590 & . & Lugger & & 2.83 \\
\hline 2 & 605595 & & Hot Cell Cask & $325-\mathrm{A}$ & 0.019 \\
\hline 2 & 605595 & & Lugger & 3732 & 2.83 \\
\hline 3 & 30060 & $1 \mathrm{ea}$ & Lugger & 3732 & 2.83 \\
\hline 3 & 30060 & I ea & Lugger & 327 & 2.83 \\
\hline 3 & 30060 & $8 \mathrm{ea}$ & Mik Pail Cask & 327 & 0.006 \\
\hline
\end{tabular}




\begin{tabular}{|c|c|c|c|c|c|}
\hline Month \& Year & $\square$ & $80 x \#$ & $\because \because \cdots, \because \cdots$ & $\therefore$ & \\
\hline$\quad \quad \quad \quad 3 \mathrm{~s}$ & Materials $\mathrm{S}$ & At the 300 Y Burial $\mathrm{C}$ & rounds $\quad \therefore \quad, \quad$ o & $\therefore \quad \therefore \quad \therefore \quad \therefore$ & $\because$ volume \\
\hline Date & २ Survey Record & No ol Cont & स $\quad$ Type of contanter & Generator & (cum) \\
\hline 3 & 30060 & 1 ea & Truck Load Waste Drum & 313 & 6.64 \\
\hline 4 & 134 & & Hot Cell Cask & $325-\mathrm{A}$ & 0.019 \\
\hline 4 & 605649 & 1 ea & Lugger & 325-A & 2.83 \\
\hline 4 & 605649 & & Milk Pail Cask & 327 & 0.006 \\
\hline 4 & 605649 & 1 ea & Truck Load Thorium Waste Drum & 313 & 6.64 \\
\hline 5 & 601075 & 1 ea & Lugger & 3730 & 2.83 \\
\hline 5 & 605609 & 1 ea & Lugger & 3706 & 2.83 \\
\hline 5 & 605609 & 2 ea & Lugger & 3732 & 2.83 \\
\hline 5 & 605609 & & Truck Load Thorium Waste Drum & 313 & 6.64 \\
\hline 8 & 150 & & Box, Plywood & $325-B$ & 3.624556 \\
\hline 8 & 605618 & & Gatling Gun Cask & 327 & 0.0113 \\
\hline 8 & 605619 & $2 \mathrm{ea}$ & Lugger & 327 & 2.83 \\
\hline 9 & 153. & $1 \mathrm{ea}$ & Lugger & 340 & 2.83 \\
\hline 9 & 155 & 1 ea & Lugger (Pu Waste) & $325(530)$ & 2.83 \\
\hline 11 & 605643 & i ea & Lugger & 327 & 2.83 \\
\hline 11 & .605643 & 8 ea & Milk Pail Cask & 327 & 0.006 \\
\hline 11 & 605643 & 1 ea & Truck Load & 327 & 6.64 \\
\hline 12 & 183 & $1 \mathrm{ea}$ & Lugger & 340 & 2.83 \\
\hline 12 & 605647 & . & Milk Pail Cask & 327 & 0.006 \\
\hline 15 & 605657 & & Hot Cell Cask & $325-A$ & 0.019 \\
\hline 15 & 605657 & $2 e a$ & Lugger & 327 & 2.83 \\
\hline 16 & 994 & & Box. Plywood & $325 \cdot B$ & 3.624556 \\
\hline 17 & 605666 & . & Hot Cell Cask & $325-\mathrm{A}$ & 0.019 \\
\hline 19 & 605675 & & Hot Cell Cask & $325 \cdot \mathrm{A}$ & 0.019 \\
\hline 23 & 605690 & & Milk Pail Cask & 327 & 0.006 \\
\hline 24 & 605690 & & Mik Pail Cask & 327 & 0.006 \\
\hline 25 & 605695 & & Weste - No More Data & 325 & $\begin{array}{l}\text { Waste - No } \\
\text { More Data }\end{array}$ \\
\hline 26 & 900995 & & Lugger & 329 & 2.83 \\
\hline Mon 8 year & Whar 65 & 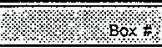 & 17950 & & $20 \%$ \\
\hline & Kkmateriass & 10 the 300 Y sutalo & ropos & & volume \\
\hline Date & Sures Recold & 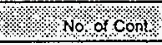 & 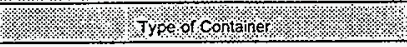 & Generator & (cum) \\
\hline 1 & $30011 / 30013$ & $2 \mathrm{ea}$ & Box, Plywood (Fitter) Leadlined & 327 & 3.624556 \\
\hline 1 & 30013 & $1 \mathrm{ea}$ & Gatling Gun Cask & 327 & 0.0113 \\
\hline 2 & 30014 & & Hot Cell Cask & $325-A$ & 0.019 \\
\hline 2 & 30014 & $8 \mathrm{ea}$ & Milk Pail Cask & 327 & 0.006 \\
\hline 3 & 000009 & & Lugger (Hot Waste) & 3730 & 2.83 \\
\hline 3 & 30017 & & Milk Pail Cask & 327 & 0.005 \\
\hline 3 & 000010 & & Truck Load (Thoria Drums) & 321 & 6.64 \\
\hline 4 & 30014 & 1 ea & Lugger (Thoria Waste) & 3732 & 2.83 \\
\hline 5 & 30024 & & Lugger & 327 & 2.83 \\
\hline
\end{tabular}




\begin{tabular}{|c|c|c|c|c|c|}
\hline Month \& Year & Mar-65 & $\therefore \quad 80 x=$ & 97950 & - & \\
\hline \& $\quad \square$ & $\therefore$ unaterials s & ent to the 30or Buriai $G$ & rounds : & 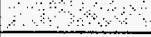 & Volume \\
\hline Date & Survey Record & No of Cont & ४ि Type of Container $४{ }^{\prime}$ & Qeneralor & (cu.m) \\
\hline 5 & 30027 & 1 ea & Lugger (AN \& Si) & 313 & 2.83 \\
\hline 9 & 000056 & & Hot Cell Cask & $325-B$ & 0.0094 \\
\hline 9 & 30033 & & Lugger & 327 & 2.83 \\
\hline 9 & 30033 & 5 ez & Milk Pail Cask & 327 & 0.006 \\
\hline 10 & 000058 & $\therefore$ & Hot Cell Cask & $325-\mathrm{A}$ & 0.019 \\
\hline 10 & & $5 \mathrm{ea}$ & Milk Pail Cask & 327 & 0.006 \\
\hline 11 & 000056 & & Hot Cell Cask & $325-\mathrm{A}$ & 0.019 \\
\hline 12 & 30047 & $4 \mathrm{ea}$ & Lugger & 327 & 2.83 \\
\hline 15 & 30057 & 9 ea & Milk Pail Cask & 327 & 0.006 \\
\hline 16 & 30060 & & Wrapped Fitter & $325 \cdot \mathrm{A}$ & $\begin{array}{l}\text { Wrapped } \\
\text { Filler }\end{array}$ \\
\hline 18 & 30071 & $1 \mathrm{ea}$ & Gatling Gun Cask (5 Rhr) & 327 & 0.0113 \\
\hline 18 & 30071 & 1 ea & Lugger & 3706 & 2.83 \\
\hline 22 & 30077 & $1 \mathrm{ea}$ & Lugger & 3732 & 2.83 \\
\hline 23 & 30079 & $1 \mathrm{ea}$ & Lugger & 3732 & 2.83 \\
\hline 23 & 30082 & $1 \mathrm{ea}$ & Lugger & 327 & 2.83 \\
\hline 24 & 30088 & & Milk Pail Cask & 327 & 0.005 \\
\hline 25 & 30091 & 1 ea & Lugger & 3732 & 2.83 \\
\hline 25 & & & Lugger (Graphite Boat) & 3730 & 2.83 \\
\hline 25 & 30091 & & Lugger (Hot Shop Waste) & 3730 & 2.83 \\
\hline 26 & 30097 & 1 ea & Lugger & 329 & 2.83 \\
\hline 29 & 30104 & $2 \mathrm{ea}$ & Mikk Pail Cask & 327 & 0.006 \\
\hline 30 & 30112 & & Lugger & 3706 & 2.83 \\
\hline 30 & 30112 & $1 \mathrm{ea}$ & Lugger ( $0.5 \mathrm{R} / \mathrm{hr})$ & 327 & 2.83 \\
\hline 31 & 000117 & $1 \mathrm{ea}$ & Milk Pail Cask & 327 & 0.005 \\
\hline 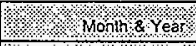 & 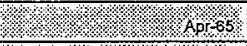 & $3.1 \% .6 \mathrm{BO}$ H & $17950 \%, 4.4$ & & $1 . \%, \%$ \\
\hline . & Materials se & At to the $300 \times$ Buria 0 & ondo & . & volume \\
\hline 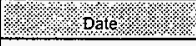 & 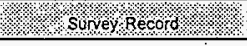 & W. $1000 \mathrm{con}$ & $4 \% 4$ yyge or containe & senerar & $(c u, m)$ \\
\hline 1 & 000048 & & Lugger & 326 & 2.83 \\
\hline 2 & 124 & $1 \mathrm{ea}$ & Gatling Gun Cask & 327 & 0.0193 \\
\hline 7 & 139 & & Milk Pail Cask & 327 & 0.006 \\
\hline 7 & 142 & 1 ea & * Lugger (w/ 2 CWS Filter) & 325 & 2.83 \\
\hline 12 & 154 & & Milk Pail Cask & 327 & 0.006 \\
\hline 13 & 157 & & Hot Cell Cask & $325-\mathrm{A}$ & 0.019 \\
\hline 13 & 158 & & Hot Cell Cask & $325-\mathrm{A}$ & 0.019 \\
\hline 14 & 162 & $1 \mathrm{ea}$ & Hot Cell Cask & 325.A & 0.019 \\
\hline 14 & 162 & & Milk Pail Cask & 327 & 0.006 \\
\hline 14 & 170 & & - Hot Cell Cask & 325-A 603 & 0.019 \\
\hline 15 & 165 & $3 \mathrm{ea}$ & Hot Cell Cask & $325 \cdot \mathrm{A}$ & 0.019 \\
\hline 15 & 165 & 1 ea & Lugger & 3706 & 2.83 \\
\hline 16 & 168 & & Hot Cell Cask & $325-\mathrm{A}$ & 0.019 \\
\hline
\end{tabular}




\begin{tabular}{|c|c|c|c|c|c|}
\hline Month \& Year & A A APr-65 & Box \# & $\therefore \quad:$ & $\therefore \therefore \therefore \quad \therefore$ & \\
\hline मे & n Materials $s$ & ent to the $300 Y$ Burial $C$ & rounds $\because \quad: \quad \because \quad: \quad \begin{array}{llll}\cdots & \cdots \\
\end{array}$ & 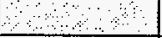 & Volume \\
\hline 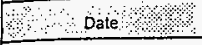 & के Survey Record & No. of Cont & S Type of Container $\mathrm{ph}$ & Generator & (cuim) \\
\hline 16 & 168 & 1 ea & Lugger & 3732 & 2.83 \\
\hline 16 & 168 & 1 ea & Lugger & 327 & 2.83 \\
\hline 16 & 168 & 1 ea & Lugger & 329 & 2.83 \\
\hline 19 & 173 & & Lugger & 3718 & 2.83 \\
\hline 19 & 173 & - & Milk Pail Cask & 327 & 0.005 \\
\hline 19 & 188 & $2 e a$ & - Lugger & 328 & 2.83 \\
\hline 19 & 188 & t ea & - Lugger (Pu Waste) & $325 / 530$ & 2.83 \\
\hline 20 & 178 & & Gatling Gun Cask & 327 & 0.0113 \\
\hline 20 & 178 & 2 ea & Hot Cell Cask & $325-A \& B$ & 0.019 \\
\hline 20 & 195 & 7 ea & - Hot Cell Cask & $325-B$ & 0.019 \\
\hline 22 & 179 & 1 ea & Lugger & 3706 & 2.83 \\
\hline 22 & 179 & & Milk Pail Cask & 327 & 0.006 \\
\hline 23 & 191 & $2 \mathrm{ea}$ & Truck Losd (Drums) & 327 & 6.64 \\
\hline 26 & 195 & & Lugger & 327 & 2.83 \\
\hline 27 & 199 & & Hot Cell Cask & 325.8 & 0.0094 \\
\hline 27 & 199 & $\therefore$ & Hot Cell Cask & $325 \cdot \mathrm{A}$ & 0.019 \\
\hline 27 & 223 & $7 \mathrm{ea}$ & - Hot Cell Cask & $325-B$ & 0.089 \\
\hline 30 & 209 & $7 \mathrm{ea}$ & Hot Cell Cask & $325-\mathrm{A}$ & 0.019 \\
\hline 30 & 209 & 1 ea & Lugger & 3706 & 2.83 \\
\hline 30 & 209 & $1 \mathrm{ea}$ & Lugger & 309 & 2.83 \\
\hline 30 & 209 & $1 \mathrm{ea}$ & Truck (Minor Construckion Debris) & 309 & 6.64 \\
\hline 30 & 97238 & & - Lugger (Pu Waste Carton) & $325 / 530$ & 2.83 \\
\hline \multicolumn{6}{|l|}{ - Note: Box \# 17952} \\
\hline Whont 8 Year & $4.2 \%$ Mar 65 & $1 \% 1 \%$ Boxt & 17850 & & m \\
\hline 1/। & W. W Materials se & Al to the 300 Y Burial $G$ & onds & & Volume \\
\hline \&pate & Whrakpond & W No of Cont & Type of contants & Kkenerator & $(\mathrm{com})$ \\
\hline 3 & 17250 & & - Lugger, High Betal Gamma & & 2.83 \\
\hline 4 & 00076 & & Lugger & 329 & 2.83 \\
\hline 4 & 00217 & & Lugger & 327 & 2.83 \\
\hline 5 & 00221 & & Milk Pail Cask & $\cdot 327$ & 0.005 \\
\hline 6 & 00224 & & Milk Pail Cask & 327 & 0.005 \\
\hline 10 & 00230 & & Lugger & 325 & 2.83 \\
\hline 10 & 00230 & & Milk Pail Cask & 327 & 0.006 \\
\hline 10 & RSR & 2 ea & - Wooden Boxes & & 1.812278 \\
\hline 10 & RSR & 4 ea & - Lugger & & 2.83 \\
\hline 10 & 17310 & & - Lugger (Waste Carton to 200 Area) & 3251530 & 2.83 \\
\hline 10 & 17286 & 2 ea & - Wooden Boxes (C-Cell) & $325-A \dot{A}$ & 1.812278 \\
\hline 11 & 00232 & & Lugger & $327 / 3706$ & 2.83 \\
\hline 12 & 00242 & . & Milk Pall Cask & $327 / 309$ & 0.005 \\
\hline 13 & 00091 & & Lugger & 326 & 2.83 \\
\hline
\end{tabular}




\begin{tabular}{|c|c|c|c|c|c|}
\hline Month \& Year & $\because 2$ & Box \# & $\therefore \quad-\quad 1 \quad$ & $\because$ & \\
\hline $8 \quad \cdots$ & \& Materials S & ent to the 300 Y Burial $\mathrm{C}$ & rounds $\quad$ a & and & Volume \\
\hline Dape & \& Survey Record & No of Con & ब्य Type of Container & Generato & (cum) \\
\hline 17 & 00250 & & Gatting Gun Cask & 327 & 0.0113 \\
\hline 17 & 00249 & & Lugger & 327 & 2.83 \\
\hline 18 & 00094 & & Lugger & 329 & 2.83 \\
\hline 19 & 00263 & & Hot Cell Filter & 327 & 0.019 \\
\hline 19 & 00263 & $\cdot$ & Milk Pail Cask & 327 & 0.006 \\
\hline 20 & 00268 & & Lugger & 327 & 2.83 \\
\hline 24 & 00275 & & Lugger & $3707-\mathrm{C}$ & 2.83 \\
\hline 24 & 00275 & & Milk Pail Cask & 327 & 0.005 \\
\hline 25 & 00281 & & Gatling Gun Cask & 327 & 0.0113 \\
\hline 25 & 00281 & & Lugger & $3707-\mathrm{C}$ & 2.83 \\
\hline 25 & 302284 & & Lugger & $3707 \cdot c$ & 2.83 \\
\hline 25 & 00284 & & Lugger & 3732 & 2.83 \\
\hline 28 & 00115 & & Lugger & 329 & 2.83 \\
\hline \multicolumn{6}{|l|}{ - Note: $80 x \# 17952$} \\
\hline Monill $2 \mathrm{Year}$ & , Jun-65: & 18.8, Box +4 & $17950 \% \% \%$ & & +ि \\
\hline 1. & (1.4. 4 Matefials se & nt to the 300 8urials & poynds $.4 .4 \%$ & $1 . \% . \%$ & Volumes \\
\hline pole $\%$ \% & Survey Record & $3.1 \% 0 \%$ Con & Wyper convinet & Genertor & ( (culm) \\
\hline 1 & 00291 & . & Milk Pail Cask & $\begin{array}{r}327 \\
\end{array}$ & 0.006 \\
\hline 3 & 00295 & & Lugger & 327 & 2.83 \\
\hline 3 & 00385 & & - Hot Cell Cask & $325-8$ & 0.019 \\
\hline 7 & 00301 & & Lugger & 327 & 2.83 \\
\hline 7 & 00385 & & Milk Pail Cask & 327 & 0.006 \\
\hline 7 & 00401 & & - Hot Cell Cask & $325-\mathrm{A}$ & 0.019 \\
\hline 7 & 00391 & & - Lugger & 325 & 2.83 \\
\hline 8 & 00386 & 2 ea & Lugger & $327 / 3732$ & 2.83 \\
\hline 8 & 00303 & & Milk Pail Cask & 325-B & 0.006 \\
\hline 8 & 00303 & & Mik Pail Cask & $325-\mathrm{A}$ & 0.006 \\
\hline 8 & 00400 & & - Lugger (Pu Waste) & $603 / 325$ & 2.83 \\
\hline 9 & 00308 & $8 \mathrm{ea}$ & Milk Pail Cask & 327 & 0.006 \\
\hline 9 & 00405 & & - Lugger & 325 & 2.83 \\
\hline 10 & 00318 & $6 \mathrm{ea}$ & Hot Cell Cask & $325-8$ & 0.0094 \\
\hline 10 & 00318 & 2 ea & Lugger & $325-B$ & 2.83 \\
\hline 11 & 00127 & & Lugger & 321 & 2.83 \\
\hline 14 & 00356 & & Lugger & 3732 & 2.83 \\
\hline 15 & 00322 & & Lugger & 327 & 2.83 \\
\hline 16 & 00327 & $2 \mathrm{ea}$ & Lugger & $328 / 305$ & 2.83 \\
\hline 16 & 00327 & $8 \mathrm{ea}$ & Mik Pail Cask & 327 & 0.006 \\
\hline 16 & 00425 & & - Hot Cell Cask & $325-\mathrm{A}$ & 0.019 \\
\hline 18 & 00362 & & Lugger & 327 & 2.83 \\
\hline 21 & 00340 & & CWs Fitter & 327 & CWS Filser \\
\hline
\end{tabular}




\begin{tabular}{|c|c|c|c|c|c|}
\hline Month \& Year & $1 \quad$ Jun-65 & $\therefore \quad B O X *$ & $\begin{array}{l}2 \\
2\end{array}$ & $\vdots^{\cdots} \cdots$ & \\
\hline$\therefore \quad \therefore$ & $\therefore \quad$ Materials Se & It to the $300 \mathrm{Y}$ Burial G & rounds $\quad$ - $\quad$ - & $\therefore \quad \because \quad \cdots$ & Volume \\
\hline +s pate & Survey Record & $\therefore \quad$ No of Cont & S+ Type of Contaner & Senerator & (cu.m) \\
\hline 21 & 00340 & & Gatling Gun Cask & 327 & 0.0113 \\
\hline 22 & 00343 & & Gatling Gun Cask & 327 & 0.0113 \\
\hline 22 & 00343 & & Lugget. & 327 & 2.83 \\
\hline 22 & 00441 & & * Lugger & 325 & 2.83 \\
\hline 23 & 00347 & $8 \mathrm{ea}$ & Mik Pail Cask & 327 & 0.006 \\
\hline 24 & 00351 & & Lugger & 3732 & 2.83 \\
\hline 25 & 00355 & 4 ea & Lugger & 327 & 2.83 \\
\hline 25 & 00355 & 7 ea & Milk Pail Cask & 327 & 0.006 \\
\hline 28 & 00361 & & Hot Cell Cask \& Step Plug \& Filier & 327 & 0.019 \\
\hline 28 & $\mathrm{RSR}$ & $28 \mathrm{es}$ & - Concreted Rad Boxes (JAJ) & 3704 & 0.764555 \\
\hline 29 & 00362 & & Gatling Gun Cask & 327 & 0.0113 \\
\hline 30 & 00358 & & Lugger & $3707 \cdot \mathrm{C}$ & 2.83 \\
\hline \multicolumn{6}{|l|}{ - Note: Box \# 17952} \\
\hline ४ै Month \& Year & 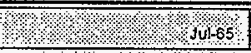 & ४२, Box \# & $17950 \%$ & \% & कर \\
\hline & $14 \%$ Y Malerials $\mathrm{se}$ & to the 300 Y Bural or & ronds & & Volume \\
\hline Date & W survey Record $/ \%$ & $20 \mathrm{No}$ of Cont & \% 1 rype of Containe & Woneralo & स(curri) \\
\hline 1 & 00369 & & Lugger & $3707-\mathrm{C}$ & 2.83 \\
\hline 1 & 00371 & & Truck Load - Drums & 1171 & 6.64 \\
\hline 6 & 00384 & & Lugger & 327 & 2.83 \\
\hline 9 & 482 & & - Lugger & & 2.83 \\
\hline 12 & 00396 & & Unknown - Assume Cell Cask & $325-\mathrm{B}$ & $\begin{array}{l}\text { Unknown - } \\
\text { Assume Cell } \\
\text { Cask }\end{array}$ \\
\hline 12 & 485 & & - Hot Cell Cask & & 0.019 \\
\hline 14 & 605405 & 32 ea & Truck, Drums - Be & 333 & 6.64 \\
\hline 14 & 00405 & & Hot Cell Cask & $325 \cdot \mathrm{B}$ & 0.0094 \\
\hline 14 & 605405 & & Lugger & 309 & 2.83 \\
\hline 14 & 00405 & & Lugger & 325 & 2.83 \\
\hline 14 & 605405 & $\dot{0}$ & Milk: Pail Cask & - 327 & 0.005 \\
\hline 19 & & & Lugger & 329 & 2.83 \\
\hline 20 & 605417 & 3 ea & Gatling Gun Cask & 327 & 0.0113 \\
\hline 20 & 605417 & & Lugger & 329 & 2.83 \\
\hline 21 & 605422 & & Lugger & 327 & 2.83 \\
\hline 21 & & & Lugger & 3730 & 2.83 \\
\hline 21 & 605422 & & Milk Pail Cask & 327 & 0.005 \\
\hline 22 & 605424 & & Gatting Gun Cask & 327 & 0.0113 \\
\hline 22 & 605424 & & Hot Cell Cask & $325-A$ & 0.019 \\
\hline 22 & & & Hot Cell Cask & $325-A$ & 0.019 \\
\hline 22 & 605424 & & Lugger & , & 2.83 \\
\hline 23 & 605425 & $\cdot$ & Lugger & & 2.83 \\
\hline 25 & & & - Hot Cell Cask & & 0.019 \\
\hline
\end{tabular}




\begin{tabular}{|c|c|c|c|c|c|}
\hline Month \& Year & J Jü 65 & Box \# & 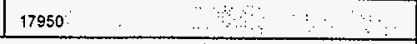 & & \\
\hline ४ & Materials Se & ent to the 300 Y Burial $G$ & 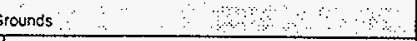 & $\therefore \quad \therefore$ & Volume \\
\hline Date & survey Recold $\%$ & No of Cont & 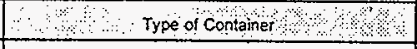 & Q Generator & (cum) \\
\hline 26 & 605524 & 2 ea & Lugger & & 2.83 \\
\hline 26 & 605435 & 7 ea & Milk Pail Cask & & 0.006 \\
\hline 26 & 605435 & $3 \mathrm{ea}$ & Milk Pail Cask (5 Gal Can) & & 0.006 \\
\hline 26 & - & & - Hot Cell Cask & & 0.019 \\
\hline 26 & & . & - Large Can Cask & & 0.0566 \\
\hline 26 & 605436 & & - Large Can Cask & & 0.0566 \\
\hline 27 & 30446 & & Lugger (Floor Tile) & 313 & 2.83 \\
\hline 27 & 605440 & 7 ea & - Gatling Gun Cask & & 0.0113 \\
\hline 27 & & & - Large Can Cask & & 0.0566 \\
\hline 28 & 226 & & - Milk Pail Cask & & 0.006 \\
\hline 29 & 30442 & 6 ea & Hot Cell Cask & 325-B & 0.0094 \\
\hline 29 & 17534 & 7 ea & Hot Cell Cask & $325 . \mathrm{B}$ & $0.00 \$ 4$ \\
\hline 29 & 17527 & & Hot Cell Cask \& 2 Pump & 325-A & 0.019 \\
\hline 29 & 30442 & $3 \mathrm{ea}$ & Large Can Cask & $325-\mathrm{A}$ & 0.0566 \\
\hline 29 & 30442 & 2 ea & Lugger & 37328327 & 2.83 \\
\hline 29 & & & - Large Can Cask & & 0.0565 \\
\hline 29 & & & - Large Can Cask & & 0.0566 \\
\hline 30 & 17531 & & Hot Cell Cask & $325-\mathrm{A}$ & 0.019 \\
\hline 30 & 30449 & $3 \mathrm{ea}$ & Hot Cell Cask & $325 \cdot \mathrm{A}$ & 0.019 \\
\hline 30 & & $3 \mathrm{ea}$ & - Large Can Cask & & 0.0556 \\
\hline \multicolumn{6}{|l|}{ - Note: Box \#17952 } \\
\hline Mont $2 \mathrm{rear}$ & Avg 65 & 8.8 Box $\#$ & 17950 & & $1 \%$ \\
\hline & Materias se & to the $300 \mathrm{Y}$ Burbl G & lounds $, 4,4 \%$ & . & volume \\
\hline Date.., & Survy Record & No of cont & $14 \%$ Type or containe & Oeneror & (culm) \\
\hline 2 & 30476 & & Hot Cell Cask & $325-\mathrm{A}$ & 0.019 \\
\hline 2 & 30476 & & Lugger & 327 & 2.83 \\
\hline 4 & 30453 & 1 ea & Milk Pail Cask & 327 & 0.006 \\
\hline 5 & 30467 & & Lugger & 327 & 2.83 \\
\hline 5 & 30463 & & Milk Pail Cask & 327 & 0.006 \\
\hline 6 & 30467 & & Lugger & 3732 & 2.83 \\
\hline 11 & 30473 & $3 \mathrm{ea}$ & Lugger & 327 & 2.83 \\
\hline 11 & 30473 & 3 ea & Lugger & 327 & 2.83 \\
\hline 11 & 30473 & $8 \mathrm{ea}$ & Mitk Pail Cask & 327 & 0.006 \\
\hline 11 & 30473 & $8 \mathrm{ez}$ & Milk Pail Cask & 327 & 0.006 \\
\hline 13 & 30476 & & Hot Cell Cask & $325-8$ & 0.0094 \\
\hline 13 & 30476 & & Hot Cell Cask & $325-8$ & 0.0094 \\
\hline 13 & 30476 & & Hot Cell Cask & $325-B$ & 0.0094 \\
\hline 16 & 30487 & $2 \mathrm{ez}$ & Milk Pail Cask & 327 & 0.006 \\
\hline 18 & 30489 & $2 \mathrm{ea}$ & Milk Pail Cask & 327 & 0.006 \\
\hline 24 & 30502 & & Hot Cell Cask & 325-A & 0.099 \\
\hline
\end{tabular}




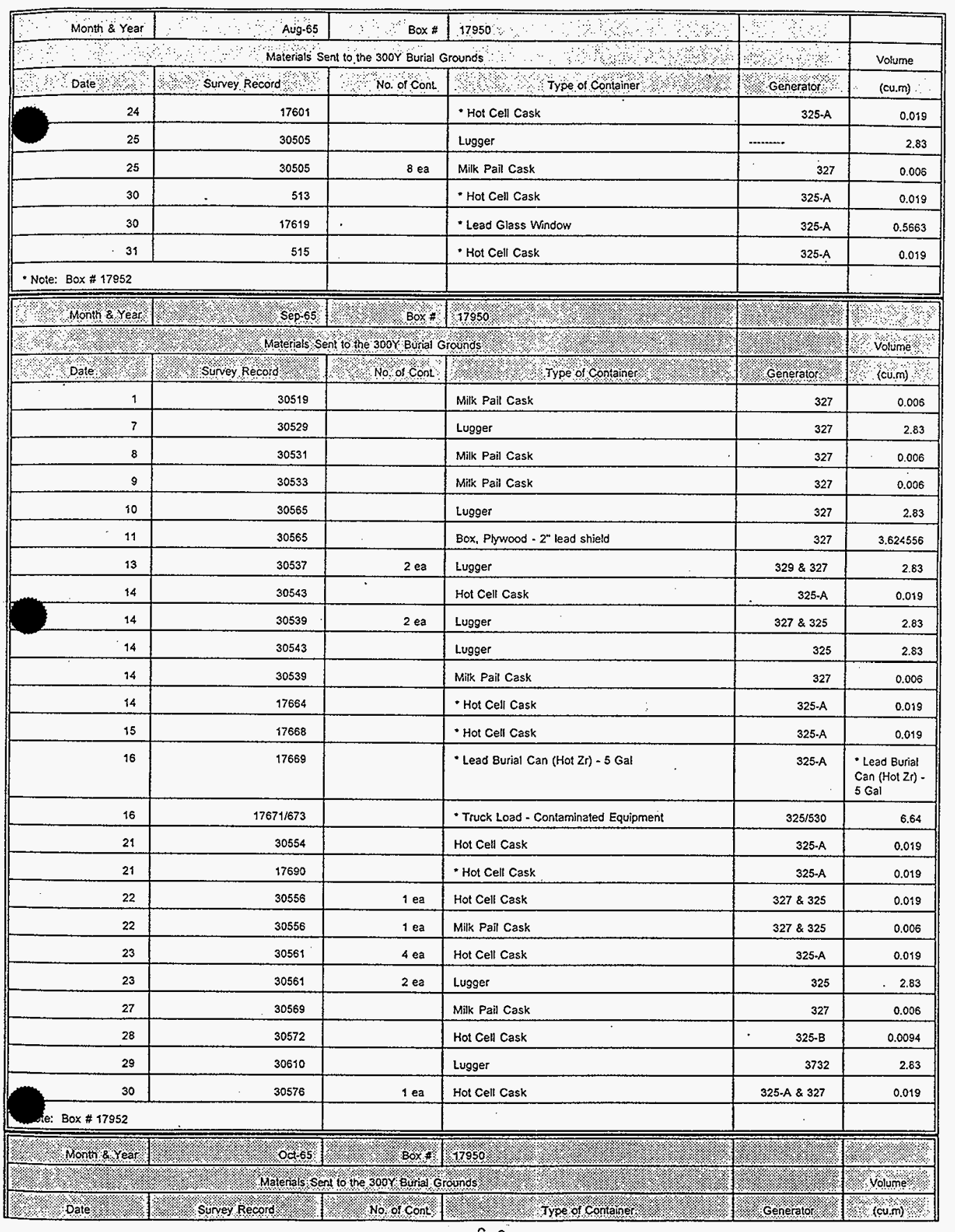




\begin{tabular}{|c|c|c|c|c|c|}
\hline 4 & 30582 & & Milk Pail Cask & 327 & 0.005 \\
\hline 5 & 30584 & & Gatting Gun Cask & 327 & 0.0113 \\
\hline 8 & 30637 & & Lugger & & 2.83 \\
\hline 8 & 30537 & & Milk Pail Cask & 327 & 0.006 \\
\hline 11 & 30538 & & Lugger & 3732 & 2.83 \\
\hline 12 & 30593 & & Gatling Gun Cask & 327 & 0.0113 \\
\hline 13 & 30596 & $2 \epsilon a$ & Lugger & $327 \& 309$ & 2.83 \\
\hline 13 & 30596 & $\therefore$ & Milk Pail Cask & 327 & 0.006 \\
\hline 15 & 30605 & & & $325 \& 3706$ & \\
\hline 15 & 30605 & 7 ea & Milk Pail Cask & 327 & 0.005 \\
\hline 15 & 30605 & 2 ea & Trueks (Dump) & & 6.64 \\
\hline 15 & 17767 & . & - Lugger & 325 & 2.63 \\
\hline 18 & 3722 & & $\cdots$ Hot Cell Cask & $325-8$ & 0.019 \\
\hline 19 & 30612 & & Hol Cell Cask & $325 \cdot \mathrm{B}$ & 0.019 \\
\hline 19 & 17777 & $3 \mathrm{ea}$ & Hot Cell Cask & $325 \cdot \mathrm{B}$ & 0.019 \\
\hline 19 & 30612 & 3 ea & Lugger & & 2.83 \\
\hline 19 & 30619 & & Lugger & 327 & 2.83 \\
\hline 20 & 30617 & & Hot Cell Cask & 325-A & 0.019 \\
\hline 20 & 17784 & & Hot Cell Cask \& Filter & $325-\mathrm{A}$ & 0.019 \\
\hline 20 & 30517 & & Milik Pail Cask & 327 & 0.005 \\
\hline 21 & 30623 & & Hot Cell Cask & $325-\mathrm{A}$ & 0.019 \\
\hline 21 & 30623 & - & Milk Pail Cask & $327^{\circ}$ & 0.006 \\
\hline 25 & 30530 & & Hot Cell Cask & $325-\mathrm{A}$ & 0.019 \\
\hline 27 & 30535 & $3 \mathrm{ea}$ & Hot Cell Cask & $325-\mathrm{A}$ & 0.019 \\
\hline 27 & 17802 & 3 ea & Hot Cell Cask & $325-\mathrm{A}$ & 0.019 \\
\hline 27 & 30635 & & Lugger & & 2.83 \\
\hline 27 & 30635 & 7 ea & Milk Pail Cask & 327 & 0.006 \\
\hline 28 & 30640 & 7 ea & Milk Pail Cask & 327 & 0.006 \\
\hline 31 & RSR & & * Truck Load Equip - Drying Oven, Grinder, Mixer & 308 & 5.66 \\
\hline \multicolumn{6}{|l|}{ - Note: Box \# 17952} \\
\hline \multicolumn{6}{|l|}{ Note: Box \# 17947} \\
\hline \%. Month \& Year) & 18\% 65. & $\mathrm{BOx}+1$ & 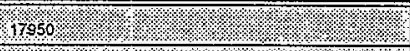 & & $1.4 \%$ \\
\hline & Marenals:s & to the $300 \times$ Burial G & ouths & \% & Volume \\
\hline (1. & 3. Survey pecorr & N. No or Cont & 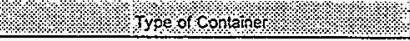 & Generalor & (cu.m) \\
\hline 2 & 00321 & & Lugger & 329 & 2.83 \\
\hline 3 & 000649 & & Hot Cell Cask & $325-\mathrm{A}$ & 0.019 \\
\hline 3 & 000649 & & Lugger (Fu Waste) & 325 & 2.83 \\
\hline 4 & 000657 & & Gatling Gun Cask. & 327 & 0.0193 \\
\hline 4 & 000657 & & Lugger (Fithers) & 327 & 2.83 \\
\hline 5 & 000658 & & Milk Pall Cask & 327 & 0.006 \\
\hline 8 & 000665 & & Flatbed Truck (Drums?) & 306 & 6.64 \\
\hline 8 & 000661 & $\cdot$ & Lugger & 3732 & 2.83 \\
\hline 8 & 000665 & & Lugger & 309 & 2.83 \\
\hline
\end{tabular}




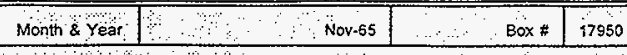

. ${ }^{2}$ Materials Sent to the 300Y Burial Grounds

\begin{tabular}{l|l|l|l|}
\hline Date- Survey Record & No of Cont
\end{tabular}

$\therefore$

\begin{tabular}{|c|c|}
\hline 9 & 000675 \\
\hline 10 & 000677 \\
\hline 10 & 000677 \\
\hline 11 & 000681 \\
\hline 12 & 000586 \\
\hline 12 & 000329 \\
\hline 15 & 000705 \\
\hline 15 & 000705 \\
\hline 15 & 000705 \\
\hline 17 & 000708 \\
\hline 17 & 000708 \\
\hline 19 & 000714 \\
\hline 22 & 000718 \\
\hline 24 & 000724 \\
\hline 30 & 000740 \\
\hline 30 & 000740 \\
\hline
\end{tabular}

\begin{tabular}{|l|l}
\hline of Cont & \multicolumn{1}{|c}{ d Type of } \\
& Milk Pail Cask \\
\hline & Lugger \\
\hline & Milk Pail Cask \\
\hline 2 ea & Lugger \\
\hline 2 ea & Lugger \\
\hline 9 ea & Lugger \\
\hline 4 ea & Milk Pail Cask \\
\hline 9 ea & Lugger \\
\hline 8 ea & Hotk Pail Cask \\
\hline 1 ea & Lugger \\
\hline
\end{tabular}

Type of Container

volume

(1)

(2)

Monk \& Y ear Dec 65

\% 1 Box +17050

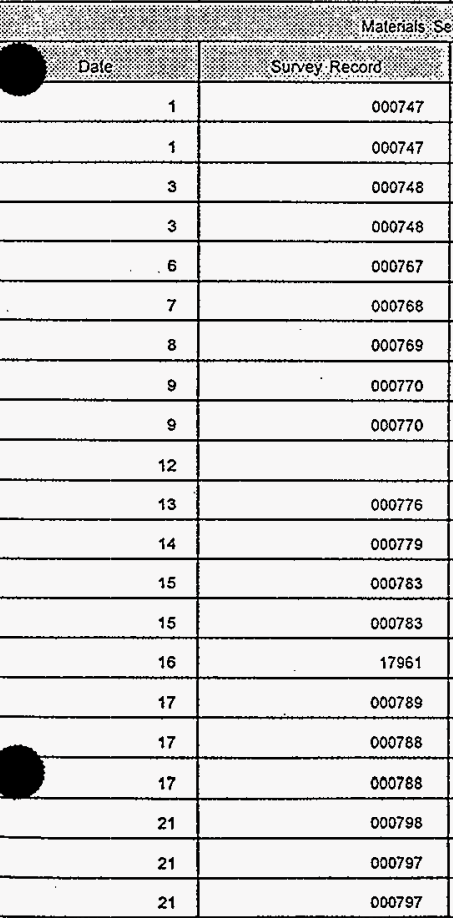

$\$$ 


\begin{tabular}{|c|c|c|c|c|c|}
\hline Month \& Year. & Dec-65 & Bcx \# & 17950 & & \\
\hline$\because \mathrm{Qu}$ & $\checkmark \quad$ Materials $s$ & ent to the 300 Y Burial $C$ & 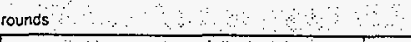 & $\because \cdots$ & Volume \\
\hline स Date & मे survey Record & $\therefore$ No of Cont & Sype ol confaine & Generator & (cu,m) \\
\hline 21 & 000802 & & Truck Load Scrap Metal - Uranium Container & 333 & 6.64 \\
\hline 23 & 000804 & 8 ea & Mîk Pail Cask & 327 & 0.005 \\
\hline 27 & 000805 & & Milk Pail Cask & 327 & 0.006 \\
\hline 29 & 000809 & & Lugger & 1171 & 2.83 \\
\hline 4 Monto 8 Yeat & $1 \% \%$ Jan-65: & मै०े вox : & $17948.4 \%$ \% & 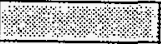 & बा \\
\hline $4 \%, \%$ & 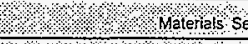 & ent to the 300 Y Butial $\mathrm{G}$ & 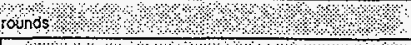 & \% & : volume \\
\hline Pate $\%$. & . Survey Recor & P No of cont & 4.4 Type of container 1 & qenerator & \% (cum) \\
\hline 5 & 00825 & & Milk Pail Cask & 327 & 0.000 \\
\hline 6 & 30893 & & Lugger & 327 & 2.83 \\
\hline 12 & 00839 & & Min Pail Cask & 327 & 8.5 \\
\hline 12 & & & Truck (Pywood \& Plexiglass) & $325 / 603$ & 6.64 \\
\hline 14 & 00840 & & Galling Gun Cask & 327 & 0.0113 \\
\hline 14 & 00841 & & Truck - Concrele Drums & 327 & 6.64 \\
\hline 17 & 00844 & & Lugger & 327 & 2.83 \\
\hline 17 & 00844 & & Milk Pail Cask & 327 & 0.006 \\
\hline 18 & 00847 & & Mik Pall Cask & $325-\mathrm{B}$ & 0.006 \\
\hline 19 & 00844 & & Lugger & 327 & 2.83 \\
\hline 19 & 30923 & & Lugger & $303-5$ & 2.83 \\
\hline 20 & 00855 & & Milk Pail Cask & 327 & 0.006 \\
\hline 21 & 00852 & & Lugger & 3732 & 2.83 \\
\hline 24 & 00863 & & Lugger & 327 & 2.83 \\
\hline 25 & 00870 & 2 ea & Cask - Graphite Waste & 327 & $\begin{array}{l}\text { Cask - } \\
\text { Graphite } \\
\text { Waste } \\
\end{array}$ \\
\hline 25 & 00871 & & Lugger & 3706 & 2.83 \\
\hline 25 & 00871 & & Lugger & 3732 & 2.83 \\
\hline 26 & 00872 & & Maik Pail Cask & 327 & 0.006 \\
\hline 27 & 00877 & 1 ea & Lugger & 327 & 2.83 \\
\hline 27 & 00877 & $7 \mathrm{ea}$ & Makk Pail Cask & 327 & 0.006 \\
\hline 28 & 00897 & & Gatling Gun Cask & 327 & 0.0113 \\
\hline Monin a Year & \% rebos & $80 \times+7$ & 17948.1. & & \\
\hline & 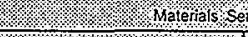 & to the $300 \%$ Burial $\mathrm{s}$ & rounds. & & volume \\
\hline & Surverecord & . & 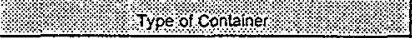 & $\mathrm{G}-\mathrm{nenal}_{\mathrm{r}}$ & (coum) \\
\hline 1 & 00851 & 2 ea & Gatling Gun Cask & 327 & 0.0113 \\
\hline 3 & 1088 & & - Lugger - $3 \mathrm{Rhr}$ & 325 & 2.83 \\
\hline 4 & 00886 & & Lugger & $327 / 329$ & 2.83 \\
\hline 4 & RSR & & - Lugger & 329 & 2.83 \\
\hline 8 & 00897 & & Gatling Gun Cask & 327 & 0.0113 \\
\hline 14 & 30973 & & - Lugger & 3732 & 2.83 \\
\hline 14 & 00905 & & - Lugger & $3707-C$ & 2.83 \\
\hline 15 & RSR & & Fumace & 326 & 0.283 \\
\hline
\end{tabular}




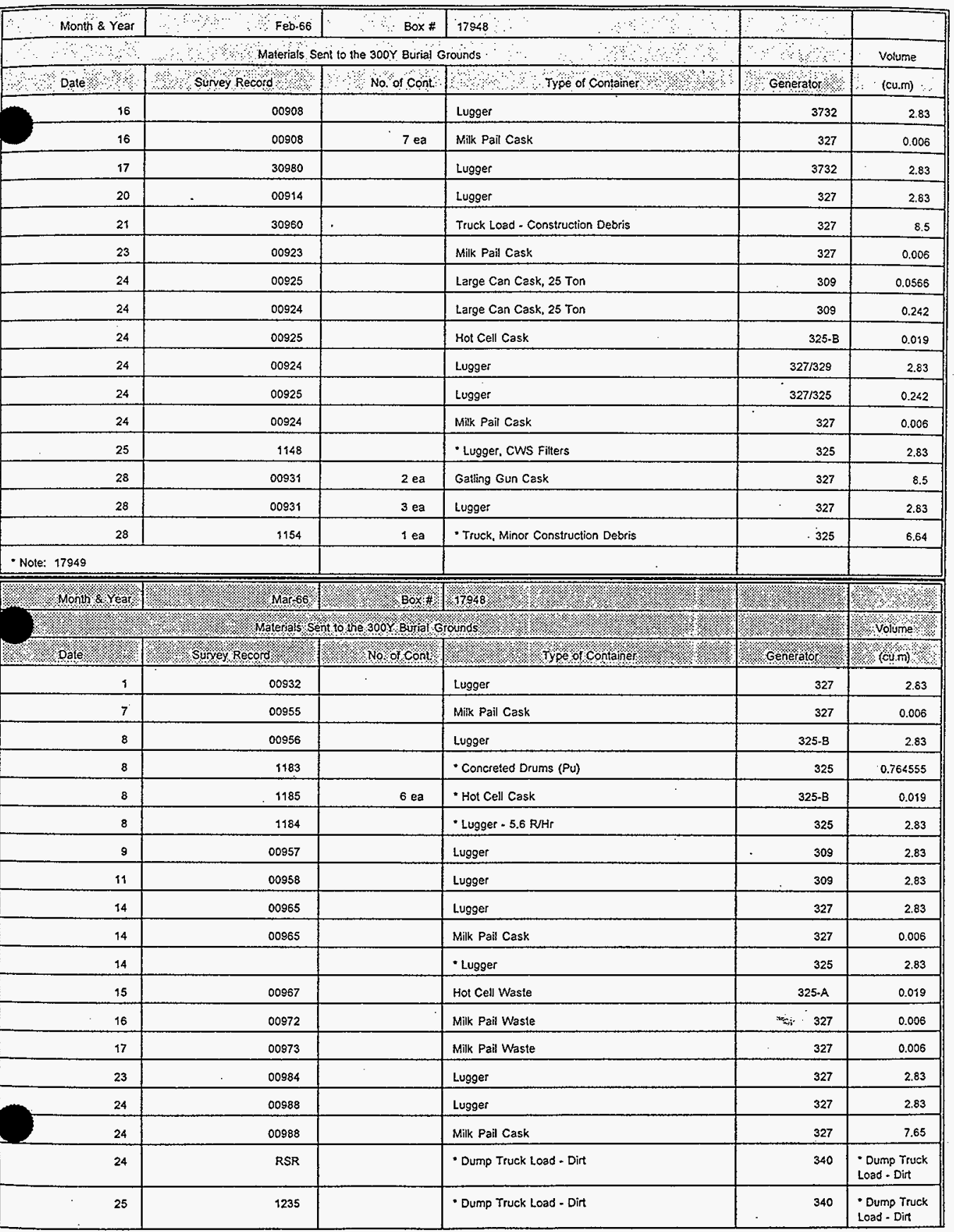




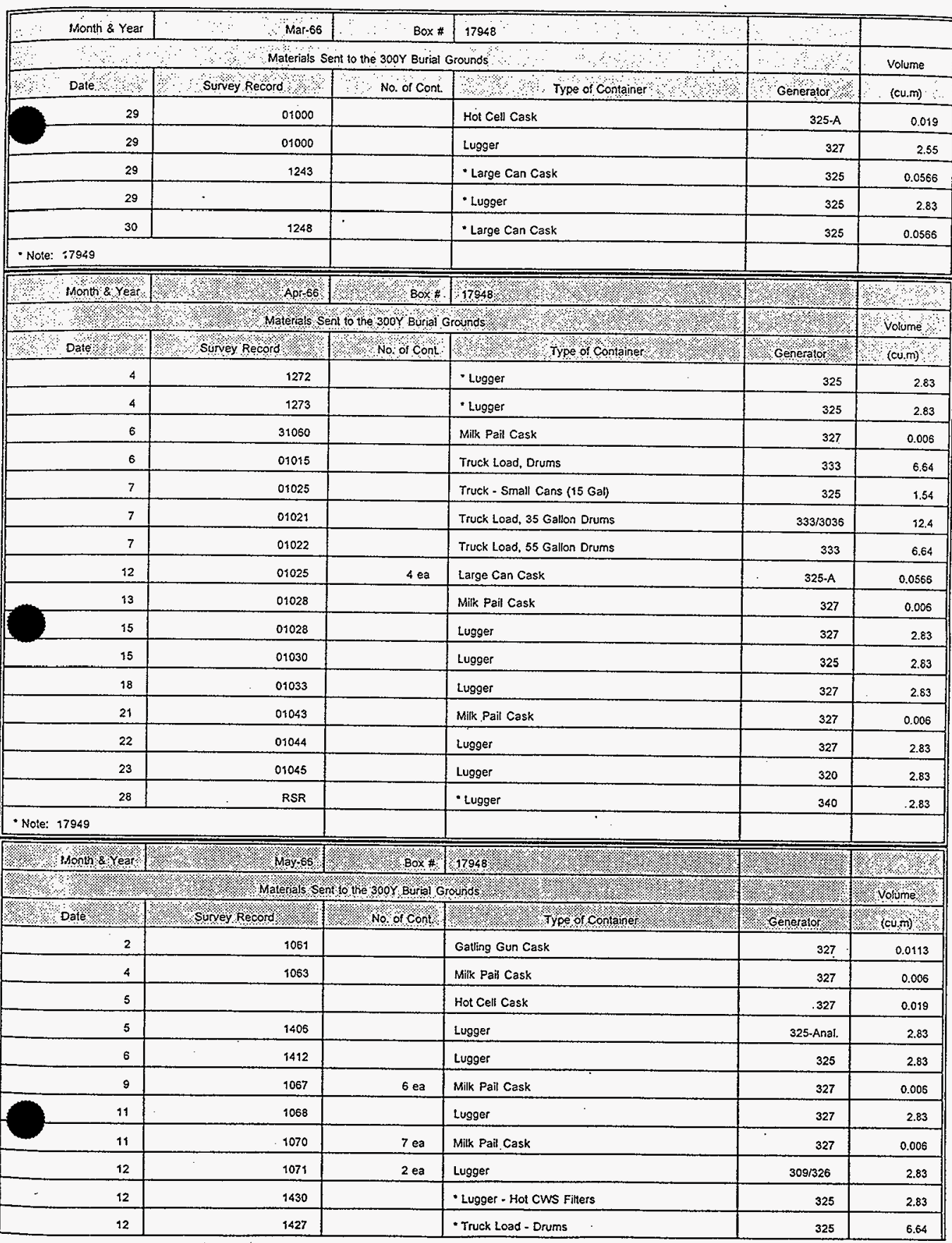




\begin{tabular}{|c|c|c|c|c|c|}
\hline Month \& Year & $\therefore \quad$ Q May-66 & $\therefore \quad \therefore \quad$ Box 7 & $\therefore \quad \therefore \therefore \%$ & $\therefore \therefore$ & \\
\hline$\therefore \quad \because \quad \because \quad \because$ & Materials Se & it to the 300 Y Burial & ב & $\because \therefore \quad$ a & Volume \\
\hline$\quad \quad$ Dale & + Survey Record & No of Cont & 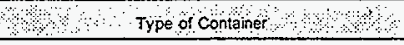 & Generator & (cuim): \\
\hline 13 & RSR & & - Lugger - Pu Sources & 325-Anal. & 2.83 \\
\hline 17 & 1079 & & Hot Cell Cask & 325-Anal. & 0.019 \\
\hline 17 & 1447 & & - Hot Cell Cask & $325-B$ & 0.019 \\
\hline 18 & 1080 & v & Hot Cell Cask (Small) & 309 & 0.019 \\
\hline 19 & 1082 & 2 ea & Glove Boxes & 380 & Glove Boxes \\
\hline 19 & 1082 & 3 ea & Hot Cell Cask & $325-8$ & 0.0094 \\
\hline 19 & 1082 & & Lugger & 308 & 2.83 \\
\hline 19 & 1461 & & - Lugger & 325 & 2.83 \\
\hline 20 & 1083 & & Hot Cell Cask & $325-A$ & 0.019 \\
\hline 20 & 1083 & & Lugger & 327 & 2.83 \\
\hline 23 & 1084 & & Lugger & 309 & 2.83 \\
\hline 24 & 1469 & & - Lugger - $3.6 \mathrm{R} / \mathrm{hir}$ & 325 & 2.83 \\
\hline 26 & .1092 & 3 ea & Hot Cell Cask & 325.8 & 0.0094 \\
\hline 26 & 1092 & i ea & Milk Pail Cask & 327 & 0.006 \\
\hline 26 & 1476 & $6 \mathrm{ea}$ & - Hot Cell Cask & $325+\mathrm{B}$ & 0.019 \\
\hline 31 & & & - Lugger & 325 & 2.83 \\
\hline \multicolumn{6}{|l|}{ - Note: 17949} \\
\hline$\% \%$ Mont \& Year & 10n 66 \% & $\mathrm{Box}+$ & 17948 & 伭 & \% \\
\hline & Materats se & to the 300 Y 8 untals & ounos & & volume \\
\hline \%) oate & \% Survey Recoro $/$ \% & \% NOOCONA & $4 \% 1 \%$ ypeolcontaine & Generato & $1 \times(c u, m)$ \\
\hline 1 & RSR & & Lugger & 321 & 2.83 \\
\hline 1 & . & & Lugger & 333 & 2.83 \\
\hline 1 & 01098 & & Milk Pail Cask & 327 & 0.006 \\
\hline 1 & 01099 & $\cdot$ & Truck Load - Drums & 333 & 6.64 \\
\hline 9 & & & Truck Load (13 Drums Be Scrap) & 333 & 6.64 \\
\hline 1 & 452 & & * Lugger & 329 & 2.83 \\
\hline 2 & 1492 & & - Hot Cell Cask & 325 & 0.019 \\
\hline 3 & 1499 & & - Lugger - CWS Filters & 325 & 2.83 \\
\hline 7 & & & Concrete Anchor & $3707-\mathrm{C}$ & 0.283 \\
\hline 14 & RSR & & - Spent Equipment - Duct \& Filter & 325 & 0.736 \\
\hline 17 & 01117 & & Lugger & 327 & 2.83 \\
\hline 20 & 01133 & & Hot Cell Cask & $325-A$ & 0.019 \\
\hline 20 & 01133 & & Milk Pail Cask & 327 & 0.006 \\
\hline 21 & 01134 & & Hot Cell Cask & 325-A & 0.019 \\
\hline 29 & 01134 & & Milk Pail Cask & 327 & 0.006 \\
\hline 22 & RSR & Q ea & Lugger, Waste Cartons (Floor Tile) & 3706 & 2.83 \\
\hline 22 & 482 & & * Lugger & 329 & 2.83 \\
\hline 22 & 1543 & & - Lugger & 325 & 2.83 \\
\hline 27 & 1144 & $12 \mathrm{ea}$ & Mitk Pail Cask & 327 & 0.006 \\
\hline 28 & 1145 & 5 ea & Mik Pail Cask & 327 & 0.006 \\
\hline
\end{tabular}




\begin{tabular}{|c|c|c|c|c|c|}
\hline Month \& Year & a jun-66 & Box \# & 17948 & $\therefore \therefore \cdots$ & \\
\hline$\therefore \quad \therefore \quad \therefore \quad \therefore$ & $\quad \therefore$ Materials $s$ & Int the sooY Burial $G$ & rounos $\quad \because \quad, \quad \because$ & -4 & $\therefore$ volume \\
\hline i Date & Su survey Record R & a No or Cont & 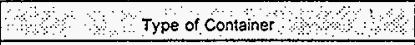 & Generato & $\therefore$ (cu.m) \\
\hline 28 & 1146 & $8 \mathrm{ea}$ & Milk Pail Cask & 327 & 0.006 \\
\hline te: 97949 & & & & & \\
\hline ßैMontr \& Yeat & $1 \% \%$ \% Jul 66 & मे, Box $\#$ & 17948 ४ & \%ో\% & 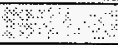 \\
\hline ४। & $10 \%$ Materiass s & nit to the 300 Y Burat $G$ & rounos & 1.2\% & Q volume \\
\hline Datel & \%ै। survey Record & Non of Conts & 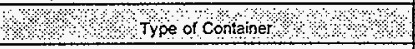 & Ganerator & (culm) \\
\hline 1 & 1152 & & Lugger $-0.3 \mathrm{R} / \mathrm{Hr}$ & 327 & 2.83 \\
\hline 7 & 1160 & & Lugger & $3707-\mathrm{C}$ & 2.83 \\
\hline 7 & 1160 & 4 ea & Milk Pail Cask & 327 & 0.006 \\
\hline 11 & 2864 & & Large Can Cask & 327 & 0.0566 \\
\hline 11 & 2864 & & Larger & 327 & 0.0566 \\
\hline 12 & $\$ 161$ & & Lugger & 329 & 2.83 \\
\hline 14 & 2877 & & Lugger & 327 & 2.83 \\
\hline 14 & 2878 & & Milk Pail Cask & 327 & 0.006 \\
\hline 14 & 2875 & $6 \mathrm{ea}$ & Milk Pail Cask & 327 & 0.006 \\
\hline 18 & 2890 & $7 \mathrm{ea}$ & Milk Pail Cask & 327 & 0.006 \\
\hline 18 & 2893 & 6 ea & Milk Pail Cask & 327 & 0.005 \\
\hline 21 & 2915 & $7 \mathrm{ea}$ & Milk Pail Cask & 327 & 0.006 \\
\hline 25 & 2924 & & Cell Equipment & 327 & $\begin{array}{l}\text { Cell } \\
\text { Equipment }\end{array}$ \\
\hline 25 & 2927 & & Tubes & 327 & 0.566 \\
\hline 26 & & $1 \mathrm{ea}$ & Lugger (Hot Waste) & 329 & 2.83 \\
\hline 26 & 2934 & $6 \mathrm{ea}$ & Miak Pail Cask & 327 & 0.566 \\
\hline 26 & 2932 & & Spent Tubes \& Pieces & 327 & $\begin{array}{l}\text { Spent Tubes } \\
\text { \& Pieces }\end{array}$ \\
\hline 28 & 2952 & & Lugger & 303-J & 2.83 \\
\hline 28 & 2949 & & Milk Pail Cask & 327 & 0.006 \\
\hline
\end{tabular}

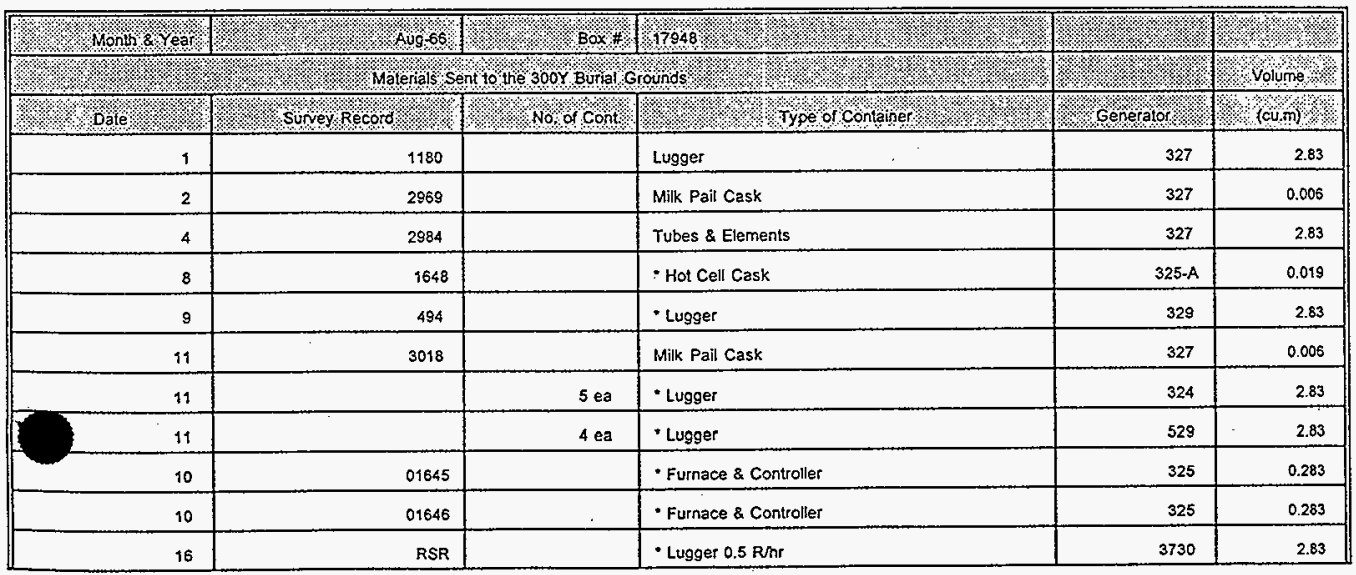




\begin{tabular}{|c|c|c|c|c|c|}
\hline Month \& Year & Q A A 66 & $\therefore \operatorname{sox} \#$ & 17928 & $\therefore \quad \therefore$ & \multirow{3}{*}{$\begin{array}{l}\text { Volume } \\
\text { (cu.m) }\end{array}$} \\
\hline \multicolumn{4}{|c|}{ 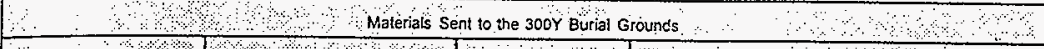 } & में & \\
\hline Date & 2. Survey Record & No of Con & S Tyoe or Container $\$$ ४ै। & Generator & \\
\hline 17 & 502 & & - Lugger $0.5 \mathrm{Rhs}$ & 3730 & 2.83 \\
\hline 19 & 3031 & & Lugger & 327 & 2.83 \\
\hline 22 & 3036 & & Milk Pail Cask & 327 & 0.006 \\
\hline 23 & 3037 & & Milk Pail Cask & 327 & 0.006 \\
\hline 23 & 3041 & ' & Milk Pail Cask & 327 & 0.006 \\
\hline 24 & 01701 & & Hot Cell Cask & $325 . \mathrm{B}$ & 0.019 \\
\hline 18 & 01673 & & & & \\
\hline 26 & 3060 & & Milk Pail Cask & 327 & 0.006 \\
\hline 30 & 3084 & & Milk Pail Cask & 327 & 0.005 \\
\hline 30 & 3065 & & Large Can Cask & 325 & 0.0566 \\
\hline - Note: 17949 & & & & & \\
\hline \% Hontr 8 year & 10.2 .4 sep-66: & ४ै, Boox & $17948,+$ ॥ & & 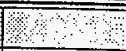 \\
\hline 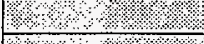 & 2.0 .4 .0 Materials se & on to the $300 \%$ Busial $\mathrm{G}$ & rounds. & & Volume \\
\hline 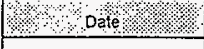 & S Survey Record $/$ & ४ै 10 o cont & 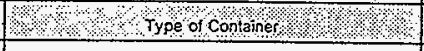 & Generalor & (cum) \\
\hline 2 & & 2 ea & - Lugger Broken Concrete & 329 & 2.83 \\
\hline 4 & & & - Lugger $<5 \mathrm{mR}$ & 329 & 2.83 \\
\hline 7 & 3087 & & Lugger & 329 & 2.83 \\
\hline 7 & 3092 & & Lugger & 325 & 2.83 \\
\hline 7 & 3093 & & Scrap Tubing & 327 & 2.83 \\
\hline 7 & $30 \subseteq 4$ & & Scrap Tubing & 327 & 2.83 \\
\hline 7 & 3095 & & Lugger & 327 & 2.83 \\
\hline 8 & 3096 & & Gatling Gun Cask & 327 & 0.0113 \\
\hline 8 & 3097 & & Scrap Tubing & 327 & 2.83 \\
\hline 12 & 3106 & & Lugger & 327 & 2.83 \\
\hline 14 & 3112 & & Lugger & 327 & 2.83 \\
\hline 22 & 3138 & & Milk Pial Cask & 327 & 0.005 \\
\hline 22 & 3139 & & Lugger & 327 & 2.83 \\
\hline 15 & 09754 & $2 \mathrm{ea}$ & - Hot Cell Equipment & $325-\mathrm{A}$ & 0.708 \\
\hline 27 & 01784 & & - Truek Load - Drums & $325-\mathrm{A}$ & 6.64 \\
\hline 16 & 01753 & & - Truck Loas - Hot Cel Equipment & $325-\mathrm{A}$ & 0.708 \\
\hline 15 & 01751 & & - Truck Load - Hot Cel Equipment & $325-\mathrm{A}$ & 6.64 \\
\hline 14 & 01749 & & - Truck Load - Hot Cel Equipment & $325-\mathrm{A}$ & 6.64 \\
\hline 15 & RSR & & - Lugger & 325 & 2.83 \\
\hline 21 & 517 & & - Lugger - $0.8 \mathrm{R} / \mathrm{hr}$ & 325.8 & 2.83 \\
\hline 26 & 1185 & & Mik Pail Cask & 327 & 0.006 \\
\hline 27 & 1186 & & Hot Cell Cask & 325.A & 0.019 \\
\hline 28 & 1987 & & Hot Cell Cask & $325 \mathrm{~A}$ & 0.019 \\
\hline 28 & 1188 & & Truck Load - Ss Piping to Drum Storage & ND & 2.83 \\
\hline 29 & RSR & & - Lugger - $4 \mathrm{R} / \mathrm{hr}$ & 3730 & 2.83 \\
\hline - Note: 17949 & & & & & \\
\hline
\end{tabular}




\begin{tabular}{|c|c|c|c|c|c|}
\hline$\cdots \quad \therefore \quad \therefore$ & $\quad$ Materials S & int to the 300 Y Burial $G$ & $\therefore \quad \vdots \quad$ & $\therefore \times$ & Volume \\
\hline Date & Suney Record & No. of Cont. & Type of Container & Generator & (cu.m) \\
\hline 1 & 1199 & & Lugger & 329 & 2.83 \\
\hline 1 & 1199 & & Lugger & 309 & 2.83 \\
\hline 4 & 1197 & & Lugger & 327 & 2.83 \\
\hline 7 & 1204 & & Lugger & 309 & 2.83 \\
\hline 10 & 1208 & $2 \mathrm{ea}$ & Milk Pail Cask & 327 & 0.006 \\
\hline 19 & 1213 & & Lugger & 327 & 2.83 \\
\hline 12 & 1217 & & Mink Pail Cask & 327 & 0.006 \\
\hline 13 & RSR & & Lugger & 3706 & 2.83 \\
\hline 17 & 1258 & & - Concreted Jugs, Pu & 305 & 0.892 \\
\hline 17 & 1227 & $2 \mathrm{ea}$ & Lugger & 327 & 2.83 \\
\hline 20 & & . & - Lugger & 327 & 2.83 \\
\hline 20 & 1242 & & Lugger & 390 & 2.83 \\
\hline 20 & 1227 & & - Lugger & 327 & 2.83 \\
\hline 21 & 1244 & & Lugger $-0.075 \mathrm{R} / \mathrm{ht}$ & 325 & 2.83 \\
\hline 24 & 1245 & & Hot Cell Cask & 327 & 0.031 \\
\hline 24 & 1245 & & Lugger & 329 & 2.83 \\
\hline 24 & 1245 & & Lugger & 309 & 2.83 \\
\hline 25 & RSR & & Truck Load - Drums, B. Th & 306 & 6.64 \\
\hline 25 & 1257 & & Truck of Equipment & $305 / 326$ & 2.83 \\
\hline 26 & & & Hot Cell Cask & 327 & 0.031 \\
\hline 31 & 01347 & & Large Can Cask, Hot Waste & 3718 & 0.0565 \\
\hline 31 & RSR-POR & & Truck, - Cask, Scrap \& Molor & 3718 & 2.83 \\
\hline 31 & 1264 & & Truck Load of Waste & 1171 & 6.64 \\
\hline 31 & 1264 & & Lugger & 1171 & 2.83 \\
\hline \multicolumn{6}{|l|}{ - Note: 17949} \\
\hline Montr \& 8 ear & Nov66 & $1 / \mathrm{Bo}+\%$ & $17848 \% 1 \%$ & & \%. \\
\hline $14.4 . \%$ & 14. & 100 te 300 sorials & ounds 1.4 .4 & 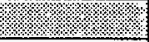 & volume \\
\hline (2. & surey Becoro & $1.1 \% \times 0100 \%$ & (1) Type of Contanet & Wereralor & $(1(\mathrm{cum})$ \\
\hline 1 & 1265 & & Lugger & 327 & 2.83 \\
\hline 2 & 1269 & & Dump Truck of 340 Soll & 340 & $\begin{array}{l}\text { Dump Truck } \\
\text { of } 340 \text { Soil }\end{array}$ \\
\hline 2 & 1269 & $3 \mathrm{ea}$ & Hot Cell Cask & $325-\mathrm{A}$ & 0.019 \\
\hline 2 & & & Large Can Cask & 3718 & 0.0556 \\
\hline 2 & 1265 & & Milk Pail Cask & 327 & 0.006 \\
\hline 2 & 1269 & & Truck Load - Equipment & 333 & 6.64 \\
\hline 2 & & & Y. 12 Bird Cages \& 1 Container Waste & 3718 & 0.212 \\
\hline 2 & $0 \$ 963$ & & - Hot Cell Cask & 325.A & 0.019 \\
\hline 2 & RSR & & - Lugger & 340 & 2.83 \\
\hline 3 & 1267 & 12 ea & Birdcage Container From Lab Pool & 3718 & $\begin{array}{l}\text { Birdcage } \\
\text { Container } \\
\text { From Lab } \\
\text { Pool }\end{array}$ \\
\hline 4 & 1277 & & Bury 324 Radiation Probe in Drum Storage Unit & 324 & 0.34 \\
\hline
\end{tabular}




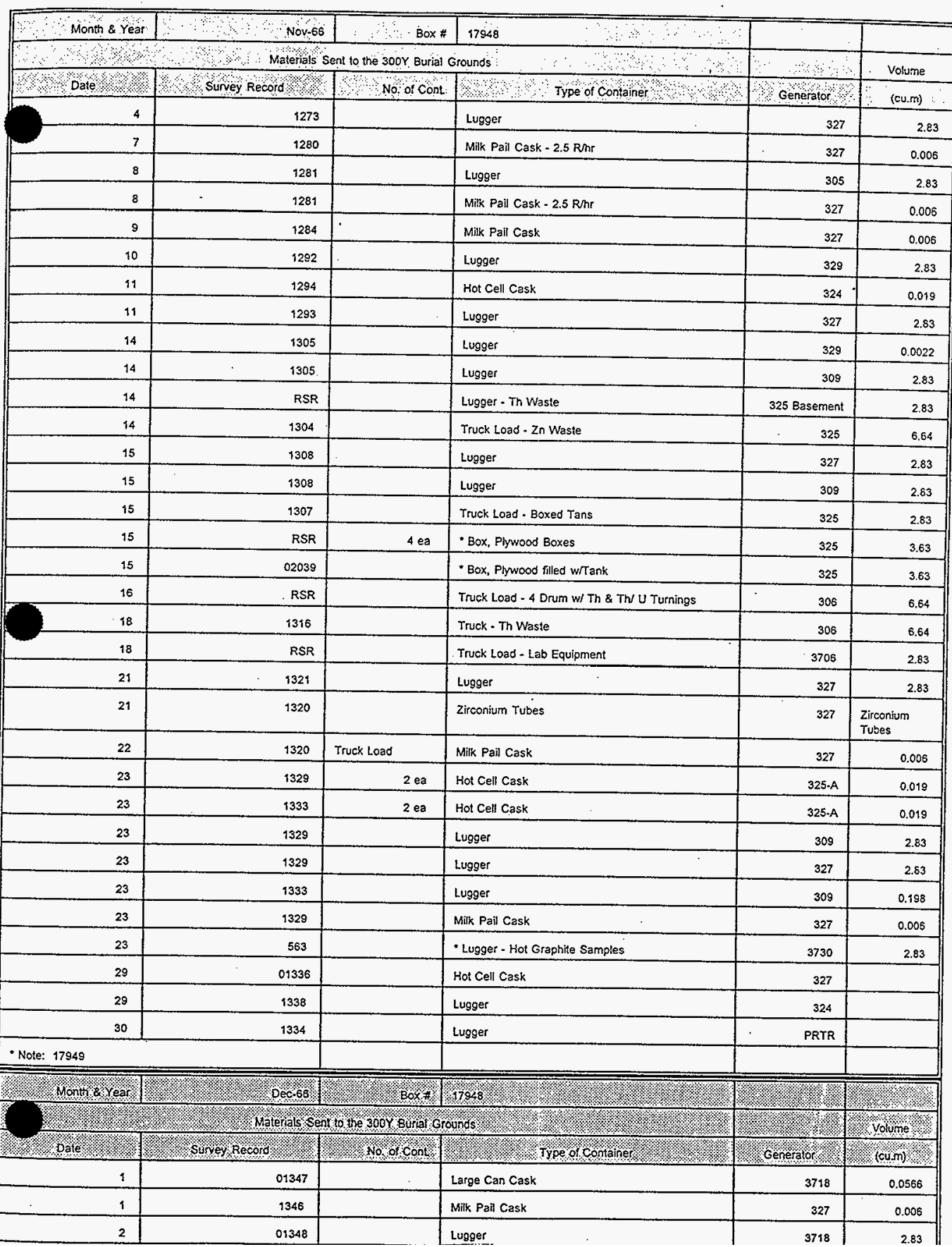




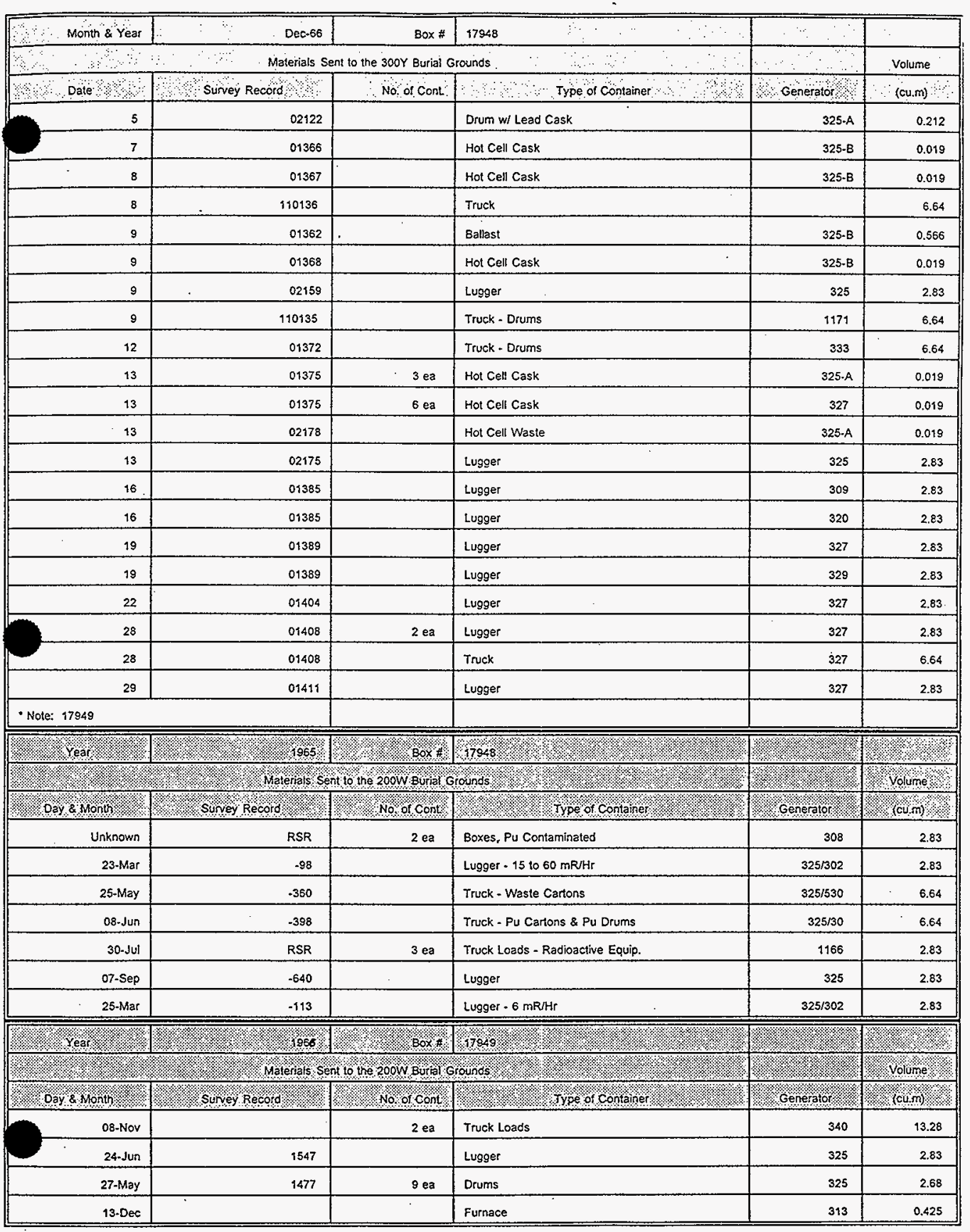




\begin{tabular}{|c|c|c|c|c|c|}
\hline $1 \%$ Box & $\mathrm{No} 13713 \mathrm{~W}$ & & & & 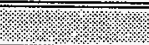 \\
\hline \multirow[t]{2}{*}{ Date } & surey Nunber & contaners & WType of contaner & generator & Yolume $(\mathrm{M} 3)^{2}$ \\
\hline & 641474 & 1 & 55 Gallon Drum Contaminated w/oil & Machine Shop & 0.21 \\
\hline $02 / 28 / 65$ & 559016 & 1 & Lugger & 308 & 2.83 \\
\hline $04 / 01 / 65$ & 650477 (RSR) & 1 & Lugger & 309 & 2.83 \\
\hline $06 / 14 / 65$ & 650707 (RSR) & 1 & Lugger & 309 & 2.83 \\
\hline $09 / 02 / 65$ & 651001 (RSR) & 1 & $\begin{array}{l}\text { Truck - tank, lights, shovels, pipes, } \\
\text { wrench set }\end{array}$ & 309 & 2.83 \\
\hline $09 / 03 / 65$ & 651002 & 1 & Lugger & 309 & 2.83 \\
\hline $09 / 14 / 65$ & 651028 & 1 & Pickup Truck - flux wire & 309 & 3.62 \\
\hline $10 / 11 / 65$ & 651128 & 1 & Lugger & 309 & 2.83 \\
\hline $10 / 20 / 65$ & 651192 & 1 & Package Load of Old Equipment & 309 & 3.62 \\
\hline $10 / 28 / 65$ & 651234 & 1 & Lugger & 309 & 2.83 \\
\hline $11 / 16 / 65$ & 651339 & 1 & Lugger, Contaminated & 309 & 2.83 \\
\hline $12 / 03 / 65$ & 651430 & 1 & Lugger - Trash & 309 & 2.83 \\
\hline $12 / 21 / 65$ & 651572 & 1 & Lugger & 324 & 2.83 \\
\hline $01 / 10 / 66$ & 660044 & 1 & Lugger & 309 & 2.83 \\
\hline $01 / 10 / 66$ & 660043 & 5 & Oil Drum & 309 & \\
\hline $01 / 14 / 66$ & 66072 & 1 & Tank Filters & 309 & 0.57 \\
\hline $02 / 02 / 66$ & 660170 & 1 & Lugger & 309 & 2.83 \\
\hline $02 / 15 / 66$ & 660262 & 1 & Lugger & 320 & 2.83 \\
\hline $02 / 21 / 66$ & 660310 & 1 & Lugger & 309 & 2.83 \\
\hline $03 / 02 / 66$ & 660397 & 1 & 25 Ton Cask. & 309 & 0.08 \\
\hline $03 / 08 / 66$ & 660414 & 1 & Lugger & 309 & 2.83 \\
\hline $03 / 11 / 66$ & 660450 & 1 & Lead Cask "Junk" & 309 & 0.06 \\
\hline $04 / 27 / 66$ & 660597 & 1 & Lugger & 309 & 2.83 \\
\hline $05 / 02 / 66$ & & 1 & Lugger & & 2.83 \\
\hline $01 / 11 / 67$ & 670021 & 1 & Lugger & 324 & 2.83 \\
\hline 1. Box & No.13714 & & & & \\
\hline patex $x$ & survey number & Contaners & Type of container & Wenertor & Yolune $(13)$ \% \\
\hline $01 / 10 / 65$ & ORSR & 1 & HEPA Filter (Sent to Herm Grey) & 309 & 0.23 \\
\hline $01 / 11 / 66$ & ORSR & 1 & Conteminated Hose Wrapped in Piastic & 309 & 2.83 \\
\hline $02 / 18 / 66$ & ORSR & 1 & Tank Truck Vent Filter & 309 & 0.57 \\
\hline $02 / 24 / 66$ & ORSR & 1 & 25 Ton Shipping Cask (Trash) & 309 & 0.08 \\
\hline $02 / 25 / 66$ & ORSR & 1 & $\begin{array}{l}25 \text { Ton Shipping Cask (Irradiated : } \\
\text { Material) }\end{array}$ & 309 & 0.05 \\
\hline
\end{tabular}




\begin{tabular}{|c|c|c|c|c|c|}
\hline $03 / 03 / 66$ & ORSR & 1 & $\begin{array}{l}25 \text { Ton Shipping Cask (Irradiated } \\
\text { Scrap) }\end{array}$ & 309 & 0.06 \\
\hline $03 / 09 / 66$ & ORSR & 1 & $\begin{array}{l}25 \text { Ton Shipping Cask (Radioactive } \\
\text { Scrap) }\end{array}$ & 309 & 0.06 \\
\hline $03 / 09 / 66$ & . ORSR & 1 & $\begin{array}{l}25 \text { Ton Shipping Cask (Radioactive } \\
\text { Waste) }\end{array}$ & 309 & 0.06 \\
\hline $03 / 11 / 66$ & ORSR & 1 & $\begin{array}{l}25 \text { Ton Shipping Cask (Irradiated } \\
\text { Scrap) }\end{array}$ & 309 & 0.06 \\
\hline $03 / 16 / 66$ & ORSR & 1 & $\begin{array}{l}25 \text { Ton Shipping Cask (Shim Rods) - } \\
\text { PRTR (ESD) }\end{array}$ & 309 & 0.06 \\
\hline $04 / 11 / 66$ & 670406 & 1 & Lugger & 309 & 2.83 \\
\hline $06 / 05 / 66$ & 660757 & 1 & Lugger & 309 & 2.83 \\
\hline $07 / 16 / 66$ & 660767 & 1 & Lugger & 309 & 2.83 \\
\hline $09 / 12 / 66$ & ORSR & 2 & Filters, $1.5 \mathrm{R} / \mathrm{hr}$ contact & PRTR (Curtis) & 0.11 \\
\hline $09 / 14 / 66$ & ORSR & 1 & Flux Wire & 309 & 0.11 \\
\hline $10 / 07 / 66$ & EDS/PRTR & 1 & \multicolumn{2}{|l|}{ Dew Cell Refrigerator, Panel \& Piping } & . \\
\hline $10 / 21 / 66$ & 660856 & 1 & Lugger & 309 & 2.83 \\
\hline $11 / 08 / 66$ & 660897 & 1 & Lugger & 309 & 2.83 \\
\hline $11 / 09 / 66$ & 660899 & 1 & Lugger & 309 & 2.83 \\
\hline $11 / 09 / 66$ & 660900 & 1 & Lugger & 309 & 2.83 \\
\hline $12 / 16 / 66$ & Routine Survey & 1 & Boxes for Burial & 309 & 3.62 \\
\hline $12 / 21 / 66$ & Routine Survey & 12 & Lugger & 309 & 2.83 \\
\hline $01 / 23 / 67$ & 670082 & 1 & Lugger & 309 & 2.83 \\
\hline $03 / 01 / 67$ & ORSR & 5 & \multicolumn{2}{|l|}{ Used Oil in Drum (PRTR maintenence) } & 0.21 \\
\hline $03 / 09 / 67$ & 670275 & 1 & Lugger & 309 & 2.83 \\
\hline $06 / 12 / 67$ & 670598 & 1 & Gas Bottle & 309 & 0.08 \\
\hline $07 / 03 / 67$ & $\begin{array}{r}\text { ORSR } \\
. \\
\end{array}$ & 1 & $\begin{array}{l}\text { Helium Bottle ICC - 3AA2265 (PRTR } \\
\text { Maintained) }\end{array}$ & 309 & 0.08 \\
\hline $08 / 01 / 67$ & 670728 & 1 & Lugger & 309 & 2.83 \\
\hline \multicolumn{6}{|c|}{$80 \times 10,13716$. } \\
\hline patex & surey Number & Contalners & Whypeof.containet & Wenerator & youme (M) \\
\hline $11 / 11 / 66$ & ORSR & 1 & Cask Probe Holder & 324 & . \\
\hline $03 / 21 / 67$ & 670232 & 2 & Filters, "B" Cell & 324 & 0.11 \\
\hline $03 / 23 / 67$ & ORSR & 1 & Wooden box with roughing fiter & 324 & 3.62 \\
\hline $05 / 03 / 67$ & ORSR & 1 & $\begin{array}{l}\text { Liquid level probe inside lead covered } \\
\text { pipe (plastic wrap) }\end{array}$ & 324 & 0.57 \\
\hline 05/10/67 & 670392 & 1 & Lugger & 324 & 2.83 \\
\hline $05 / 26 / 67$ & 671446 & 1 & Filters, 107 & 324 & 3.62 \\
\hline $05 / 26 / 67$ & ORSR & 1 & $\begin{array}{l}\text { Fitter, } 107 \text {, assembly in plywood } \\
\text { boxDry waste in garbage cans \& wood } \\
\text { box }\end{array}$ & '324 & 4.19 \\
\hline
\end{tabular}




\begin{tabular}{|c|c|c|c|c|c|}
\hline $06 / 22 / 67$ & 660021 & 1 & Lugger & 309 & 2.83 \\
\hline $07 / 28 / 67$ & ORSR & 1 & Dry waste in garbage ens \& wood box & 324 & 2,83 \\
\hline $07 / 28 / 67$ & 670634 (RSR) & 1 & Waste Box "B" Cell & 324 & 3.62 \\
\hline $09 / 27 / 67$ & ORSR & 1 & Wooden box & 324/PRCF & 3.62 \\
\hline $10 / 13 / 67$ & 670843 & 1 & Hot Wast Box & 324 & 3.62 \\
\hline $10 / 13 / 67$ & ORSR & 1 & Wooden box & 324 & 3.62 \\
\hline $10 / 31 / 67$ & ORSR & 1 & Wooden box & 324 & 3.62 \\
\hline $11 / 10 / 67$ & 670952 & 1 & Wooden Box, "B" Cell & 324 & 3.62 \\
\hline $12 / 08 / 67$ & ORSR & 1 & Wooden box & 324 & 3.62 \\
\hline $12 / 09 / 67$ & 671060 & 1 & Wooden Box, Max Dose $2 \mathrm{Rhhr}$ & 324 & 3.62 \\
\hline $12 / 10 / 67$ & ORSR & 1 & Scaffolding wrapped in plastic & 324 & 2.83 \\
\hline $12 / 14 / 67$ & 66015 & 1 & $\begin{array}{l}\text { "B" Cell Waste - Lugger/ } 2 \text { Cans/ } 1 \\
\text { Box }\end{array}$ & 324 & $\begin{array}{l}\text { "8" Cell Waste - } \\
\text { Lugger/ } 2 \text { Cans/ } 1 \\
\text { Box }\end{array}$ \\
\hline $12 / 21 / 67$ & 671115 & 1 & Wooden Box, "B" Cell & 324 & 3.62 \\
\hline $12 / 22 / 67$ & ORSR & 1 & Solid waste (SST Pipe, screen) & 324 & 2.83 \\
\hline $12 / 28 / 67$ & 671125 & 1 & Wooden Box, "B" Cell & 324 & 3.62 \\
\hline $12 / 29 / 67$ & ORSR & 1 & "B" Cell - Rod Waste in Box & 324 & $\begin{array}{l}\text { "B" Cell - Rod } \\
\text { Waste in Box }\end{array}$ \\
\hline $09 / 29 / 66$ & - RSR & 6 & Barrels - Be \& U Scrap & 333- $N$ Fuels & 0.21 \\
\hline $07 / 22 / 68$ & $-320-100$ & 4 & Waste Jugs & 320 & 2.02 \\
\hline \multicolumn{6}{|c|}{ " Note: Box No. 13717} \\
\hline ** Note: Box N & 23509 & & & & \\
\hline
\end{tabular}


HNF-EP-0649, Rev. 0

ENCLOSURE

\section{APPENDIX H \\ BATTELLE NORTHWEST LABORATORIES CONTAMINATION} INCIDENTS AT HANFORD

1956-1971 
HNF-EP-0649, Rev. 0

APPENDIX $\mathrm{H}$

\section{APPENDIX H \\ BATTELLE NORTHWEST LABORATORIES CONTAMINATION INCIDENTS AT HANFORD \\ 1956-1971}

Date Location Comment

1956

$10 / 15$

near 325

Load lugger

1957

$\begin{array}{ll}* 2 / 7 & 107 \mathrm{~F} \\ * 3 / 4 & 327 \\ * 3 / 7 & 108 \mathrm{~F} \\ * 3 / 23 & 108 \mathrm{~F} \\ * 4 / 12 & 329 \\ * 5 / 7 & 1166 \\ * 5 / 9 & 329 \\ * 5 / 10 & 329 \\ * 5 / 21 & 327 \\ * 5 / 23 & 1160 \\ * 5 / 31 & 321 \\ * 6 / 12 & 1160 \\ * 6 / 19 & 108 \mathrm{~F} \\ * 8 / 17 & 3706\end{array}$

Tore process line while excavating

Contamination spill

P-10 leak (?)

Contamination spread

Liquid Spill

Contaminated cask at stores

RuDEF spill

Pu spill

Contamination spread in building

Contaminated cask at stores

Fire

Contaminated cast at stores

${ }^{45} \mathrm{Ca}$ spill

Contamination spread

H-1 


\section{HNF-EP-0649, Rev. 0 APPENDIX H}

Date

1958

* 5/23

329

* 7/2

$108 \mathrm{~F}$

1959
Location

\section{Comment}

\author{
Contamination spread \\ Contamination spread
}

Contamination spread

Explosion in cell 
HNF-EP-0649, Rev. 0

APPENDIX $\mathrm{H}$

Date

Location

Comment

1960

$\begin{array}{lll}* 1 / 13 & 1709 \mathrm{D} & \text { Contamination spread } \\ * 7 / 20 & 325 & \text { Pu waste spread } \\ * 10 / 25 & 325-\mathrm{A} & \text { Contamination spread } \\ * 11 / 9 & 3706 & \text { Contamination spread (gas) } \\ * 12 / 8 & 327 & \text { Cask leaked }\end{array}$

1961

$\begin{array}{cll}* 3 / 15 & 327 & \text { Cask leaked } \\ * 5 / 18 & 306 & \text { U fire } \\ * 5 / 22 & 3706 & \text { Waste burned? } \\ 7 / 4 & 300 \mathrm{~N} & \text { Fire in building } \\ * 7 / 29 & 108 \mathrm{~F} & \text { Pu waste leaked out of carton } \\ 8 / 28 & 306 & \text { Fire }\end{array}$

1962

$\begin{array}{cll}* 4 / 10 & 3730 & \text { Trradiated sample exploded } \\ 4 / 10 & \text { near } 306 & \text { Fire in load lugger } \\ 8 / 28 & ? & \text { Contamination spread (cask) } \\ 9 / 11 & 327 & \text { Contamination spread } \\ 10 / 16 & 325-\mathrm{A} & \text { Liquid spill } \\ * 10 / 26 & 308 & \text { Fire in hood }\end{array}$

1963

$\begin{array}{lll}2 / 12 & 325 & \text { Pm incident } \\ 8 / 5 & ? & \text { Contamination spread } \\ 9 / 2 & 618-10(300 \mathrm{~N}) \text { burial ground } & \text { Contamination spread } \\ 9 / 30 & 618-10(300 \mathrm{~N}) \text { burial ground } & \text { Contamination spread }\end{array}$


HNF-EP-0649, Rev. 0

APPENDIX $\mathrm{H}$

Date

Location

Comment

1964

$3 / 6$

$5 / 18$

$11 / 1$

$\underline{1965}$

1966 NONE

1967

$* 2 / 22$
$3 / 23$
$4 / 7$
$4 / 14$
$6 / 13$
$10 / 17$

1968

$* 9 / 9$

325

Contamination spread

Contamination spread ?

Contamination spread Contamination spread Contamination spread Contamination spread 618-11 (Wye) burial ground ?

NONE

NONE

Fire

Contamination spread

Contamination spread

Contamination spread

Contamination spread

618-11 (Wye) burial ground Contamination spread
$?$

Basement flooded 
HNF-EP-0649, Rev. 0

APPENDIX $\mathrm{H}$

Date Location Comment

$\underline{1969}$

* 4/4 near $324 \quad$ ?

* 9/30 $325 \quad$ Contamination leak

* 11/12 $324 \quad$ Contamination spread

$12 / 10 \quad 340 \quad$ Waste spread (see DHD doc.)

* $12 / 31 \quad ? \quad \mathrm{Pu}$

$\underline{1970}$

$\begin{array}{rll}* 1 / 20 & \text { Burial ground (327) } & \text { Fission products } \\ * 1 / 20 & ? & ? \\ * 2 / 12 & 340,3719 & \text { Fission products (waste) } \\ * 6 / 15 & 327 & \text { Contamination spread } \\ * 10 / 13 & ? & { }^{3} \mathrm{H} \\ * 12 / 8 & ? & \text { Cs-137, Ce-144, Pm } \\ & & \text { contamination spread }\end{array}$

$2 / 3 \quad ?$

$3 / 13 \quad 141 \mathrm{C}-141 \mathrm{~N}$

$\mathrm{PuO}_{2}$

${ }^{90} \mathrm{Sr}$ ground contaminated 
HNF-EP-0649, Rev. 0

ENCLOSURE

\author{
APPENDIX I \\ WASTE INFORMATION DATA SYSTEM \\ GENERAL SUMMARY REPORT, VOL. 2 \\ HISS DATABASE, APPENDIX E \\ JULY 12,1990
}


Waste Information Data system

General summary Report

July 12, 1990

SITE NAME: $618-11$ [3093

AiIASES: $\quad$ B Burial Ground, 318-11 tm; 300 Wye Burial Ground [309]

SITE TYPE: $\quad$ Burial Ground [309]

WASTE CATEGORY: Pre-1970 TRU [303]

WASTE TYPE: SOlid [309]

STATUS:

BTARI DATE:

END DATE:

Inactive [309] Pre-1980 [309]

March 1962 [17]

December 1967 [17]

OPERABLE UNIT: $300-I U-1$ [329]

REG. AUTEORITY: Undefined 13231

DOE/RI RROGRAM: Radiation Areas Reduction [358]

DESTGNATED AREA: 600 Area [309]

COORDINATES: N12103 W2561, N12103 W3561, N12478.W2561, N12478 W3561 [309]

IOCATION:

$-7.5 \mathrm{mi}$ northwest of the 300 Area, directly west of WPPSS 2 [123]

CONTAMINATED SOIL VOLUME: OVERBURDEN SOIL VOIUME:

GROUND ELEVATION: 430.00 feet above MSL [309]

HATER TABLE DEPTH: $\quad 50.00$ feet below grade (309)
$7,900.00$ cubic meters [303] $18,000.00$ cubic meters [303]
SITE DIMENSIONS:
Iength:
width:
Depth:
$1,000.00$ feet $[309]$
375.00 feet $[309]$
15.00 feet $[309]$

\section{SITE DESCRIPTION:}

The site composed of three trenches, 54 pipe storage units, and 8 to 10 caissons. The trenches are $900 \mathrm{ft}$ long by $50 \mathrm{ft}$ wide (surface

dimensions). The pipe storage units are 22 in. in diameter by $15 \mathrm{ft}$ long, buried vertically, and made by welding five 55-gal drums together. The caissons are 8-ft-diameter corrugated metal pipe, $10 \mathrm{ft}$ long, buried $15 \mathrm{ft}$ below grade, connected to the surface by an offset 36-in.-diameter pipe with a dome type cap [309]. The site perimetex is marked with Identification markers 2-68-1 through 2-68-28 [17].

\section{WASTE TYPES AND AMOUNTS:}

The site contains a broad spectrum of low-to-high-level dry wastes, primarily fission products and plutonium. Low-level wastes were buried in the trenches, and high-level wastes were buried in the pipe storage units [123] and caissons [309]. 
RNOWN RELEASES:

UPR-600-4, UPR-600-5, UPR-600-6, UPR-600-7, UPR-600-8, UPR-600-9, UPR-600-10 [309].

CLEANOP ACTIONS:

The site was surface stabilized in 1983 [317]. 


\section{Waste Information Data system \\ General summary Report \\ July 12,1990}

SITB KANE: UPR-600-4 [309]

ALIASES: None

SITB TYPE: Unplanned Release [309]

HASTE CATEGORY: Mixed Waste [NR]

WASTE MYPE: Liquid 1309

8TATUS: Inactive 309$]$ Pre-1980 [309:

OCCURRENCE DATE: March 6, 1964 [309]

OPERABLE UNIT: $300-I U-1$ [329]

REG. AOTHORITY: Undefined [368]

DESIGNATED AREA: 600 ATEa [309]

COORDINATES: N12103 W2561, N12103 W3561, N12478 W2561, N12478 W3561 [309]

IOCATION: Within the 618-11 Burial Ground [309]

GROUND ELEVATION: $\quad 430.00$ feet above MSL 13091

ATER TABLE DEPTH: $\quad 50.00$ feet below grade (309)

8ITE DIKENSIONS: 8ite Area: 1,000.00 square feet [309]

MASTE TYPES AND AMOUNTS:

Waste from the High-level Radiochemistry Facility. Readings were up to $10,000 \mathrm{ct} / \mathrm{min}[309]$.

KNOWN RELEABES:

Radioactive material blew out of a waste can as it was lowered into the 618-11 Burial Ground [309].

CIEANUP ACTIONS:

The 618-11 Burial Ground was surface stabilized in 1983 [317].. 


\section{Waste Information Data system General summary Report \\ July 12,1990}

SITB NAME: UPR-600-5 [309]

AIIASES: None

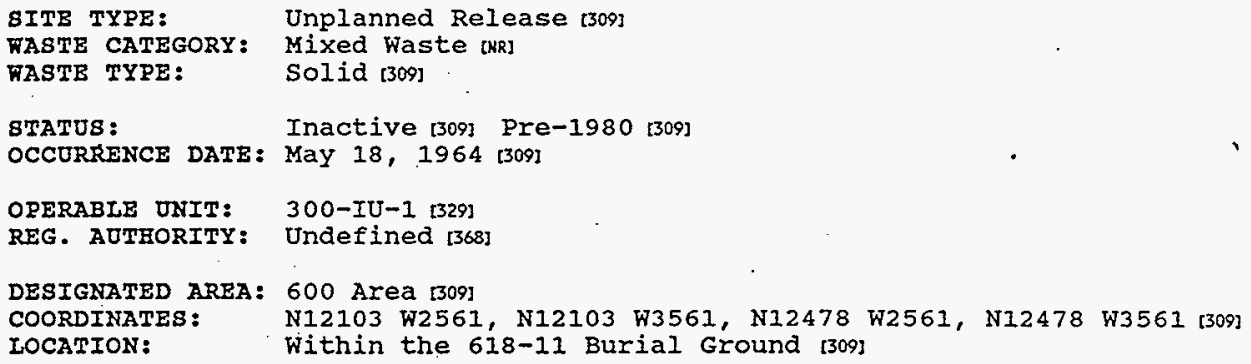

WASTE TYQES AND AMOUNTS:

Airborne contamination resulting in readings to $500 \mathrm{ct} / \mathrm{min}$ of beta/gamma of gross fission products [309].

\section{KNOWN REIEASES:}

Employees were contaminated during routine burial operations at the 618-11 Burial Ground when a fine white powder escaped from the truck chute and spilled onto the ground [309].

CLEANUP ACTIONS:

The 618-11 Burial Ground was surface stabilized in 1983 [317]. 


\section{Waste Information Data Bystem}

General summary Report

$$
\text { July } 12,1990
$$

SITE NAME: UPR-600-6 3091

ALIASES: None

8ITE TYPE: Unplanned Release [309]

WASTE CATEGORY: Mixed Waste [NR]

MASTE TYRB: SOlid [309]

8TATU8: $\quad$ Inactive [309] Pre-1980 [309]

OCCURRENCE DATE: FebruarY 8, 1965 [309]

OPERABLE UNIT: 300-IU-1 329

REG. ADTEORITY: Undefined [368]

DESIGNATED AREA: 600 Area [309]

COORDINATES: N12103 W2561, N12103 W3561, N12478 W2561, N12478 W3561 [309]

IOCATION: Within the 618-11 Burial Ground [309]

GROUND ELEVATION: 430.00 feet above MSL [309]

ATER TABLE DEPTE: $\quad 50.00$ feet below grade [309]

SITE DIMENSIONS: . Site Area: $1,400.00$ square feet [309]

MASTE TYPES AND AMOUNTS:

$\mathrm{Ru}-103$ and $\mathrm{Zr}-\mathrm{Nb} 95$ with readings from $100 \mathrm{ct} / \mathrm{min}$ to $200 \mathrm{mR} / \mathrm{h} \mathrm{[309].}$

RHOTN RELEASES:

Winds of $32 \mathrm{mi} / \mathrm{h}$ with gusts up to $44 \mathrm{mi} / \mathrm{h}$ blew waste from a truck, over an employee, and onto the ground, causing spotty contamination at the 618-11 Burial Ground [309].

CLEANOP ACTIONS:

The 618-11 Burial Ground was surface stabilized in 1983 [317]. 


\section{Waste Information Data system}

General summary Report

July 12, 1990

SITE NAME: UPR-600-7 [309]

ALIASE8: None

SITE TYPE: Unplanned Release [309]

TASTE CATEgORY: Mixed Waste [NR]

HASTE TYPE: Solid [309]

STATOS: Inactive [309] Pre-1980 [309]

OCCURRENCE DATE: March 1, 1965 [309].

OPERABLE UNIT: 300-IU-1 [329]

REG. AUTHORITY: Undefined [368]

DESIGNATED AREA: 600 Area [309]

COORDINATE8: N12103 W2561, N12103 W3561, N12478 W2561, N12478 W3561 [309]

LOCATION: Within the 618-11 Burial Ground [309]

\section{GROUND ELEVATION:}

ATER TABIE DEPTH: $\quad 50.00$ feet below grade [309]

KNOWN RELEASES:

An emloyee dropped a box containing a contaminated waste storage (CWS)

filter from 327 Building basement from the back of a truck at the 618-11 Burial Ground. Dust came out of the box and caused spotty contamination in the immediate vicinity [309].

CLEANUP ACTIONS:

The 618-11 Burial Ground was surface stabilized in 1983 [317]. 


\section{Waste Information Data system}

General summary Report

July 12, 1990

8ITE NAME: UPR $=600-8$ [3093

ALIASES: None

SITE TYPE: Unplanned Release \{309\}

WASTE CATEGORY: MiXed Waste INRI

WASTE TYPE: Solid [309]

STATUS: Inactive [309] Pre-1980 [309]

OCCURRENCE DATE: April 7, 1967 [3097

OPERABIE UNIT: 300-IU-1 [329]

REG: AUTHORITY: Undefined [368]

DESIGNATED AREA: 600 Area [309]

COORDINATES: N12103 W256i, N12103 W3561, N12478 W2561, N12478 W3561 [309]

IOCATION: $\quad$ Within the 618-11 Burial Ground [309]

GROUND ELEVATION:

ATER TABLE DEPTH:

430.00 feet above MSL [309]

50.00 feet below grade [309]

SITE DIMENSIONS: 8ite Area: $\quad 30.00$ square feet [309]

WASTE TYPES AND AMOUNTS:

Airborne contamination resulting in readings to $100,000 \mathrm{ct} / \mathrm{min}[309]$.

KANOWN · RELEASES :

The release occurred during routine burial operations, causing either air backup from a burial tank chute or loose contamination blown from the release gate of a cask as it was operated [309].

CLEANUP ACTIONS:

The 618-11 Burial Ground was surface stabilized in 1983 [317]. The area was covered with 2 to 3 in. of clean gravel [309]. 


\section{Waste Information Data system \\ - General summary Report \\ July 12, 1990}

SITE - NAME: UPR-600-9 [309]

ALIASE8: None

8ITE TYPE: Unplanned Release [309]

WASTE CATEGORY: MiXed Waste [RR]

HASTE TYPE: Solid [309]

STATUS: Inactive [309] Pre-1980 [309]

OCCURRENCE DATE: ApriI 14, 1967 [309]

OPERABLE UNIT: 300-IU-1 [329]

REG. AUTHORITY: Undefined [368]

DESIGNATED AREA: 600 Area [309]

COORDINATES: N12103 W2561, N12103 W3561, N12478 W2561, N12478 W3561 [309]

LOCATION: Within the 618-11 Burial Ground 13091

GROUND ELEVATION: 430.00 feet above MSI [309]

TATER TABLE DEPTB: 50.00 feet below grade [309]

SITE DIMENSIONS: Length: $\quad 750.00$ feet [309]

Width: 450.00 feet [309]

WASTE TYEES AND AMOUNTS:

Corroded aluminum rupture cans and pieces of an $N$ Reactor safety rod.

Readings were up to $450 \mathrm{mR} / \mathrm{h}$ at the chute [309].

KNOKN RELEASES:

During routine burial operations in the 618-11 Burial Ground, a piece of waste became wedged in the truck chute, causing an airborne release of contamination. Contamination was limited to a fan-shaped area extending northeast from the dump chute [309].

CLEANOP ACTIONS:

The 618-11 Burial Ground was surface stabilized in 1983 [317]. The area inside the fence was covered with 3 to 6 in. of gravel. Outside the fence, the top layer was bladed and covered with clean soil [309]. 


\section{Waste Information Data Bystem \\ General summary Report. \\ July 12, 1990}

SITE NAME: UPR-600-20 [309]

AIIASES: None

$\begin{array}{ll}\text { BITE TYPE: } & \text { Unplanned Release [309] } \\ \text { WASTE CATEGORY: } & \text { MiXed waste [NR] } \\ \text { WABTE TYPE: } & \text { Solid [309] } \\ & \\ \text { STATUS: } & \text { Inactive [309] Pre-1980 [309] } \\ \text { OCCURRENCE DATE: September 30, } 1963 \text { [309] }\end{array}$

OPERABLE JNIT: 300-IU-1 [329]

REG. AUTEORITY: Undefined [368]

DESIGNATED AREA: 600 Area [309]

COORDINATES: N12103 W2561, N12103 W3561, N12478. W2561, N12478 W3561 [309]

LOCATION: Around Barrel 327-2 at the 618-11 Burial Ground [309]

GROUND ELEVATION: $\quad 430.00$ feet above MSL [3091

TATER TABIE DEPTH: 50.00 feet below grade [309]

SITE DIMENSIONS: Site Area: 400.00 square feet [309]

WASTE TYPES AND AMOUNTS:

Airborne contamination resulting in readings to $1 / 4 \mathrm{R} / \mathrm{h}$ at 3 in. of high-level beta/gamma [309].

KNOFN RELEASES:

During a routine burial at the 618-11 Burial ground, a container was externally contaminated with a significant quantity of loose, highly radioactive material, causing ground contamination [309].

CLEANUP ACTIONS:

The 618-11 site was surface stabilized in 1983. The contaminated ground area was washed down with 6,000 gal of water to control blowing. The most highly contaminated earth was shovelled into waste barrels, and the whole area was covered with several inches of clean sand [309]. 


\title{
618-11 DOCUMENT DISTRIBUTION LIST
}

\author{
Central Files (1) B1-07 \\ Document Processing Center A3-93 \\ Hanford Technical Library P8-55 \\ CHI/GEO
}
K. A. Bergstrom
H9-02
L. C. Hulstrom
H9-03

B\&W Hanford Company
C. R. Johnson,
L6-06

Waste Management Federal Services of Hanford, Inc.

L. T. Blackford

T4-05

F. M. Coony,

H6-06

T. M. Greager

H6-06

W. S. Josephson

H6-06

M. R. Kerns

H6-06

D. E. McKenney

H6-06

D. E. Nester

H6-06

K. M. Quigley

S6-30

J. G. Riddelle

H6-06

U.S. Department of Energy, Richland Operations Office

DOE/RL Reading Room

$\mathrm{H} 2-53$

R. G. McLeod

$\mathrm{H} 0-12$ 


\section{$\sum$ SESC}

SGN Eurisys Services Corporation

An SGN/Cogema, Inc. Company

October 21, 1997

SESC-97-602

K. L. Hladek, Manager

Technical Baseline

Waste Management Federal

Services of Hanford, Inc.

Post Office Box 700

Richland, Washington 99352-0700

Dear Mr. Hladek:

HNF-EP-0649, REV . 0, CHANGE 1 - TABLE 3-7 CALCULATION CORRECTIONS

Attached is corrected Table 3-7 from Section 3, page 3-57 of the subject document (Attachment 1). Please replace this page in HNF-EP-0649, Rev. 0, "Characterization of the 618-11 Solid Waste Burial Ground, Disposed Wastes, and Description of the Waste Generating Facilities." Review of the table showed transposition errors from raw data which yielded calculation errors. The text is correct and this change will bring the table in line with the written information. A Record Of Revision is also included (Attachment 2).

Should you have any questions, please call me on 376-9671.

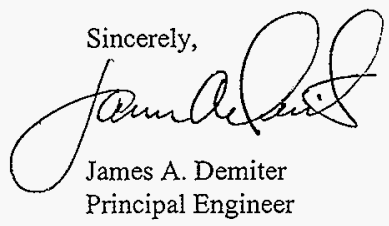

$\mathrm{cmr}$

Attachments (2) 
SESC-97-602

\section{ATTACHMENT 1}

Table 3-7, Section 3, page 3-57 of HNF-EP-0649, Rev. 0, Change 1

Consisting of 1 page 
Table 3-7: 618-10 and 618-11 Burial Ground Shipping Records

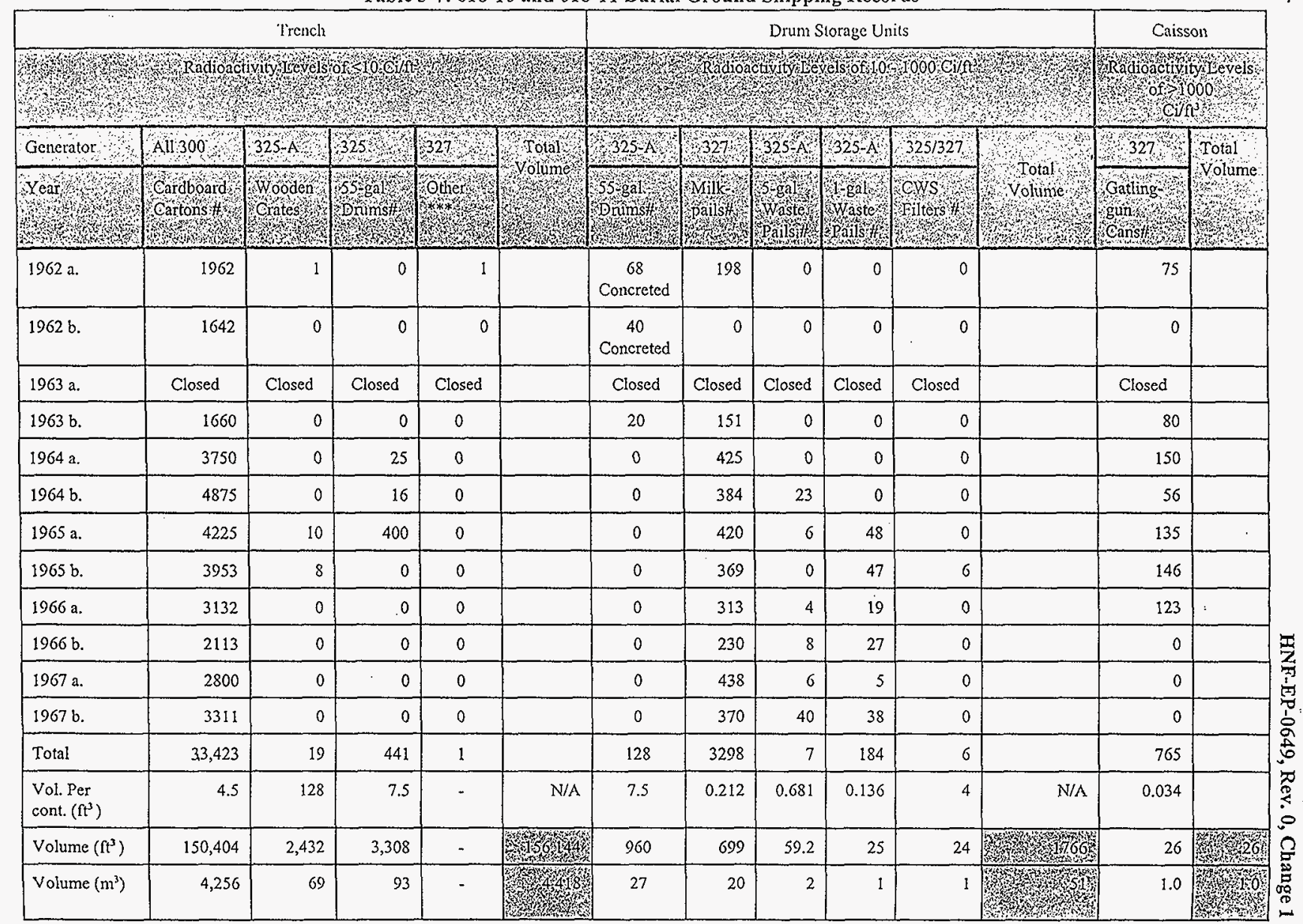


SESC-97-602

ATTACHMENT 2

Record of Revision for HNF-EP-602, Rev. 0, Change 1

Consisting of 1 page 


\section{RECORD OF REVISION}

(1) Document Number

HNF-EP-0649.

Rev. 0

(2) Title

Characterization of the 618-11 Solid Waste Burial Ground, Disposed Waste, and Description of the Waste Generating Facilities

\begin{tabular}{|c|c|c|c|c|}
\hline \multirow[b]{2}{*}{$\begin{array}{l}\text { (3) } \\
\text { Revision }\end{array}$} & \multirow{2}{*}{\multicolumn{2}{|c|}{$\begin{array}{l}\text { (4) Description of Change - Replace. Add, and Delete } \\
\text { Pages }\end{array}$}} & \multicolumn{2}{|c|}{ Authorized for Release } \\
\hline & & & $\begin{array}{l}\text { (5) Cog. } \\
\text { Engr. }\end{array}$ & (6) Cog. Mgr. Date \\
\hline $\begin{array}{l}\text { Change } 1 \\
\text { to Rev. } 0\end{array}$ & & $\begin{array}{l}\text { Table 3-7 is changed to reflect } \\
\text { corrections to calculations. Replace } \\
\text { page 3-57. }\end{array}$ & $\begin{array}{l}\text { James A. } \\
\text { Demiter } \\
\text { i }\end{array}$ & J. J. Zimmer \\
\hline & & Rev. 0, no EDT, October 1997 & tansti: & 8245 \\
\hline & & & & \\
\hline & & & & \\
\hline
\end{tabular}




\section{8-11 DOCUMENT DISTRIBUTION LIST}

Central Files (1)

Document Processing Center

Hanford Technical Library

\section{CHI/GEO}

K. A. Bergstrom

L. C. Hulstrom

B\&W Hanford Company

C. R. Johnson,

L6-06
$\mathrm{H} 9-02$

B1-07

A3-93

P8-55

H9-03

Waste Management Federal Services of Hanford, Inc.

L. T. Blackford

T4-05

F. M. Coony,

H6-06

T. M. Greager

H6-06

W. S. Josephson

H6-06

M. R. Kerns

H6-06

D. E. McKenney

H6-06

D. E. Nester

H6-06

K. M. Quigley

S6-30

J. G. Riddelle

H6-06

U.S. Department of Energy, Richland Operations Office

DOE/RL Reading Room

H2-53

R. G. McLeod

HO- 12 
K. L. Hladek, Manager

Technical Baseline

Waste Management Federal

Services of Hanford, Inc.

Post Office Box 700

Richland, Washington 99352-0700

Dear Mr. Hladek:

\section{HNF-EP-0649, REV. 0, CHANGE 1 - TABLE 3-7 CALCULATION CORRECTIONS}

- Attached is corrected Table 3-7 from Section 3, page 3-57 of the subject document (Attachment 1). Please replace this page in HNF-EP-0649, Rev. 0, "Characterization of the 618-11 Solid Waste Burial Ground, Disposed Wastes, and Description of the Waste Generating Facilities." Review of the table showed transposition errors from raw data which yielded calculation errors. The text is correct and this change will bring the table in line with the written information. A Record Of Revision is also included (Attachment 2).

Should you have any questions, please call me on 376-9671.

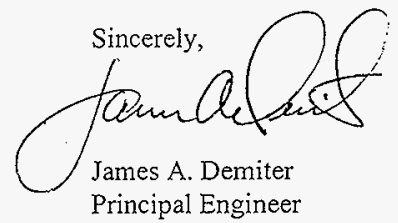

$\mathrm{cmr}$

Attachments (2) 
SESC-97-602

ATTACHMENT 1

Table 3-7, Section 3, page 3-57 of

HNF-EP-0649, Rev. 0, Change 1

Consisting of 1 page 
Table 3-7: 618-10 and 618-11 Burial Ground Shipping Records

\begin{tabular}{|c|c|c|c|c|c|c|c|c|c|c|c|c|c|}
\hline \multicolumn{6}{|c|}{ Trench } & \multicolumn{6}{|c|}{ Drum Storage Units } & \multicolumn{2}{|c|}{ Caisson } \\
\hline \multicolumn{6}{|c|}{ and } & \multicolumn{6}{|c|}{ 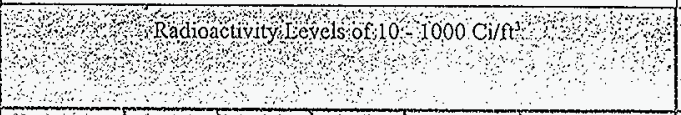 } & \multicolumn{2}{|c|}{ 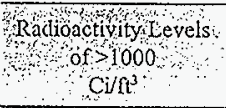 } \\
\hline Gencialor & All 300 & $325-A$ & $325 \quad \because$ & $327 \ldots$ & Total & $325-A$ & $\therefore 327$ & $325-A$ & $325-A$ & $325 / 327$ & & $\therefore 327 \because \because$ & Total \\
\hline Year & Cardoons & Wooden & Drimst & other & Volume & 55 gal & Milk & Waste & $\begin{array}{l}1-\text { gal } \\
\text { Waste } \\
\text { puijsyt }\end{array}$ & $\begin{array}{l}\text { CWS } \\
\text { lilters } \\
\end{array}$ & \begin{tabular}{c} 
Total \\
Volume \\
\hdashline$\quad$ \\
\hdashline$\quad 1$
\end{tabular} & $\begin{array}{l}\text { Gatling- } \\
\text { gut } \\
\text { Canst }\end{array}$ & \begin{tabular}{c} 
Volume \\
\hdashline \\
$\cdots$ \\
\end{tabular} \\
\hline $1962 \mathrm{a}$. & 1962 & 1 & 0 & 1 & & $\begin{array}{c}68 \\
\text { Concretcd }\end{array}$ & 198 & 0 & 0 & 0 & & 75 & \\
\hline 1962 b. & 1642 & 0 & 0 & 0 & & $\begin{array}{c}40 \\
\text { Concreted }\end{array}$ & 0 & 0 & 0 & 0 & & 0 & \\
\hline $1963 \mathrm{a}$. & Closed & Closed & Closed & Closed & & Closed & Closed & Closed & Closed & Closed & & Closed & \\
\hline $1963 \mathrm{~b}$ & 1660 & 0 & 0 & 0 & & 20 & 151 & 0 & 0 & 0 & & 80 & \\
\hline $1964 a$. & 3750 & 0 & 25 & 0 & & 0 & 425 & 0 & 0 & 0 & & 150 & \\
\hline $1964 \mathrm{~b}$. & 4875 & 0 & 16 & 0 & & 0 & 384 & 23 & 0 & 0 & & 56 & \\
\hline 1965 a. & 4225 & 10 & 400 & 0 & & 0 & 420 & 6 & 48 & 0 & & 135 & \\
\hline $1965 \mathrm{~b}$. & 3953 & 8 & 0 & 0 & . & 0 & 369 & 0 & 47 & 6 & & 146 & \\
\hline 1966 a. & 3132 & 0 & 0 & 0 & & 0 & 313 & 4 & 19 & 0 & & 123 & \\
\hline $1966 \mathrm{~b}$. & 2113 & 0 & 0 & 0 & & 0 & 230 & 8 & 27 & 0 & & 0 & \\
\hline 1967 a. & 2800 & 0 & 0 & 0 & & 0 & 438 & 6 & 5 & 0 & & 0 & \\
\hline $1967 \mathrm{~b}$ & 3311 & 0 & 0 & 0 & & 0 & 370 & 40 & 38 & 0 & & 0 & \\
\hline Total & 33,423 & 19 & 441 & 1 & & 128 & 3298 & 7 & 184 & 6 & & 765 & \\
\hline $\begin{array}{l}\text { Vol. Per } \\
\text { cont. }\left(\mathrm{ft}^{3}\right)\end{array}$ & 4.5 & 128 & 7.5 & - & $N / A$ & 7.5 & 0.212 & 0.681 & 0.136 & 4 & $N / A$ & 0.034 & \\
\hline Volume $\left(\mathrm{ft}^{3}\right)$ & 150,404 & 2,432 & 3,308 & - & 156,44 & 960 & 699 & 59.2 & 25 & 24 & Whos 1766 & 26 & 14026 \\
\hline Volume $\left(\mathrm{m}^{3}\right)$ & 4,256 & 69 & 93 & - & 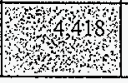 & 27 & 20 & 2 & 1 & 1 & wathos & 1.0 & कon \\
\hline
\end{tabular}




\section{SESC-97-602}

\section{ATTACHMENT 2}

Record of Revision for HNF-EP-602, Rev. 0, Change 1

Consisting of 1 page 


\section{RECORD OF REVISION}

(1) Docunent Number HNF - EP-D649,

Page $3-57$

Rev. 0

(2) Title

Characterization of the 618-11 Solid Waste Burial Ground, Disposed Waste, and Description of the Waste Generating Facilities

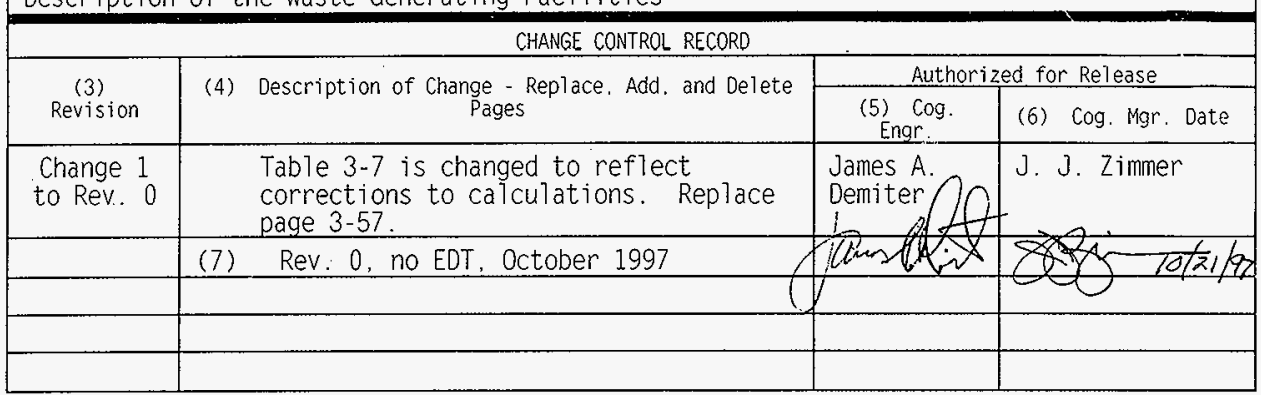

